\title{
ASEAN \\ RESISTANCE TO \\ SOVEREIGNTY \\ VIOLATION
}

INTERESTS, BALANCING AND THE ROLE OF THE

VANGUARD STATE

LAURA SOUTHGATE

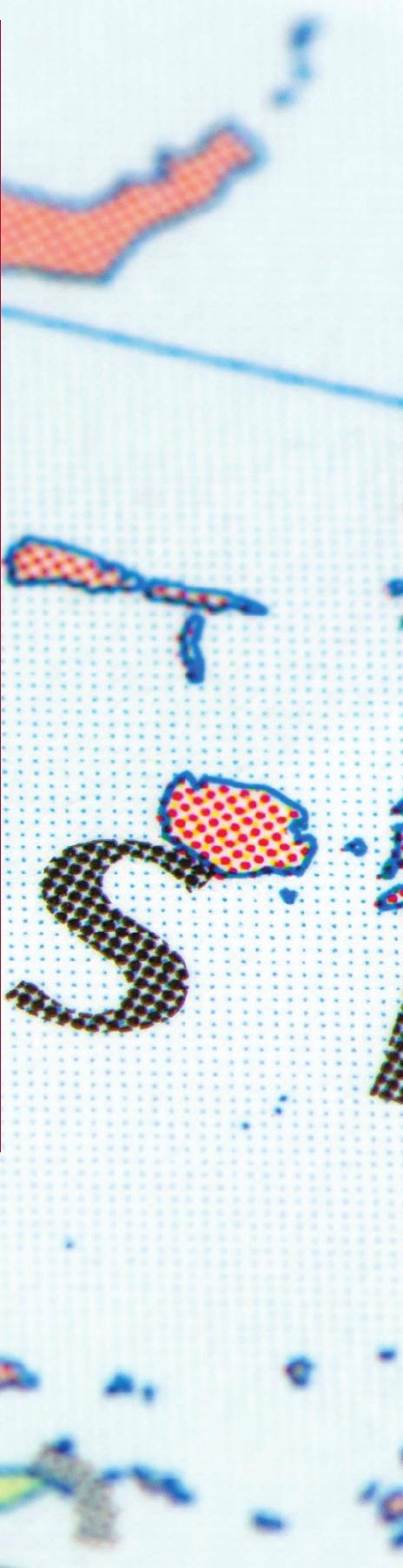

3. 


\title{
ASEAN RESISTANCE TO SOVEREIGNTY VIOLATION
}

Interests, balancing and the role of the vanguard state

\author{
Laura Southgate
}


First published in Great Britain in 2019 by

\author{
Bristol University Press \\ University of Bristol \\ 1-9 Old Park Hill \\ Bristol \\ BS2 8BB \\ UK \\ t: +44(0)1179545940 \\ pp-info@bristol.ac.uk \\ www.bristoluniversitypress.co.uk
}

North America office:

Policy Press

c/o The University of Chicago Press

1427 East 60th Street

Chicago, IL 60637, USA

t: +1 7737027700

f: +1 773-702-9756

sales@press.uchicago.edu

www.press.uchicago.edu

\section{(C) Bristol University Press 2019}

British Library Cataloguing in Publication Data

A catalogue record for this book is available from the British Library

Library of Congress Cataloging-in-Publication Data

A catalog record for this book has been requested

978-1-5292-0220-5 hardback

978-1-5292-0221-2 ePdf

978-1-5292-0222-9 ePub

978-1-5292-0223-6 Mobi

The right of Laura Southgate to be identified as author of this work has been asserted by her in accordance with the Copyright, Designs and Patents Act 1988.

All rights reserved: no part of this publication may be reproduced, stored in a retrieval system, or transmitted in any form or by any means, electronic, mechanical, photocopying, recording, or otherwise without the prior permission of Bristol University Press.

The statements and opinions contained within this publication are solely those of the author and not of the University of Bristol or Bristol University Press. The University of Bristol and Bristol University Press disclaim responsibility for any injury to persons or property resulting from any material published in this publication.

Bristol University Press works to counter discrimination on grounds of gender, race, disability, age and sexuality.

Cover design by blu inc, Bristol

Front cover image: iStock

Printed and bound in Great Britain by CPI Group (UK) Ltd, Croydon, CR0 4YY

Bristol University Press uses environmentally responsible print partners

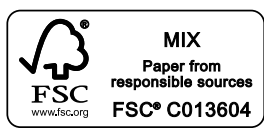




\section{Contents}

Abbreviations $\quad$ V

Acknowledgements ix

Introduction: ASEAN and the Vanguard State xi

1 Interests and Vanguard State Theory 1

2 The Indonesian Invasion of East Timor 25

3 The Third Indochina War 71

$4 \quad$ The East Timor Humanitarian Crisis 117

$5 \quad$ The South China Sea Dispute 163

6 The Future of ASEAN Sovereignty? 213

$\begin{array}{ll}\text { References } & 233\end{array}$

Index 263 



\section{Abbreviations}

ABRI Angkatan Bersenjata Republik Indonesia (Armed Forces of the Republic of Indonesia)

ADF Australian Defence Force

AFP

AFTA

Armed Forces of the Philippines

APCET

ASEAN Free Trade Area

APEC

Asia-Pacific Coalition for East Timor

Apodeti

Asia-Pacific Economic Cooperation

Associação Popular Democrática Timorense (Timorese

Popular Democratic Association)

APT

ASEAN Plus Three

ARF

ASA

ASEAN Regional Forum

ASEAN

Association of Southeast Asia

BAKIN

Association of Southeast Asian Nations

Badan Koordinasi Intelijens Negara (State Intelligence

Coordinating Body)

BP

British Petroleum

CCP

Chinese Communist Party

CGDK

CGI

Coalition Government of Democratic Kampuchea

Consultative Group on Indonesia

COC

Code of Conduct

Comecon Council for Mutual Economic Assistance

CPK

CPT

Communist Party of Kampuchea

Communist Party of Thailand

CRS

Congressional Research Service

CSCE

Conference on Security and Cooperation in Europe

DFA

Department of Foreign Affairs

DOC

Declaration of Conduct

EAS

East Asia Summit

EDCA

Enhanced Defense Cooperation Agreement

EMU

Economic and Monetary Union

EU European Union

FALINTIL Forças Armadas da Libertação Nacional de Timor-Leste (National Liberation Armed Forces of East Timor) 


\begin{tabular}{|c|c|}
\hline FON & Freedom of Navigation \\
\hline FRETILIN & $\begin{array}{l}\text { Frente Revolucionária do Timor Leste Independente } \\
\text { (Revolutionary Front for an Independent East } \\
\text { Timor) }\end{array}$ \\
\hline FRG & Federal Republic of Germany \\
\hline FUNSK & $\begin{array}{l}\text { Front Uni National pour le Salut du Kampuchéa } \\
\text { (Kampuchean United Front for National Salvation) }\end{array}$ \\
\hline GOM & Government of Malaysia \\
\hline GOS & Government of Singapore \\
\hline GRUNK & $\begin{array}{l}\text { Gouvernement Royal d'union Nationale du Kampuchéa } \\
\text { (The Royal Government of National Union of } \\
\text { Kampuchea) }\end{array}$ \\
\hline IMET & International Military Education and Training \\
\hline IMF & International Monetary Fund \\
\hline INTERFET & International Force for East Timor \\
\hline ISF & International Stabilisation Force \\
\hline JCET & Joint Combined Exchange Training \\
\hline JIM & Jakarta Informal Meeting \\
\hline JIM II & Second Jakarta Informal Meeting \\
\hline JMSU & Joint Marine Seismic Undertaking \\
\hline Kopassus & $\begin{array}{l}\text { Komando Pasukhan Khusus (Special Forces } \\
\text { Command) }\end{array}$ \\
\hline KOTA & $\begin{array}{l}\text { Klibur Oan Timur Aswain (Sons of the Mountain } \\
\text { Warriors) }\end{array}$ \\
\hline KPNLF & Khmer People's National Liberation Front \\
\hline MDT & Mutual Defence Treaty \\
\hline MILF & Moro Islamic Liberation Front \\
\hline NATO & North Atlantic Treaty Organisation \\
\hline NGO & Non-Governmental Organisation \\
\hline PCA & Permanent Court of Arbitration \\
\hline PKF & Peacekeeping Force \\
\hline PKI & $\begin{array}{l}\text { Partai Komunis Indonesia (Communist Party } \\
\text { Indonesia) }\end{array}$ \\
\hline PLA & People's Liberation Army \\
\hline PLAN & People's Liberation Army Navy \\
\hline $\mathrm{PN}$ & Philippines' Navy \\
\hline PRC & People's Republic of China \\
\hline PRG & $\begin{array}{l}\text { Provisional Revolutionary Government of the } \\
\text { Republic of South Vietnam }\end{array}$ \\
\hline PULO & Patani United Liberation Organisation \\
\hline $\mathrm{R} 2 \mathrm{P}$ & Responsibility to Protect \\
\hline RAAF & Royal Australian Air Force \\
\hline
\end{tabular}




$\begin{array}{ll}\text { RAN } & \text { Royal Australian Navy } \\ \text { RTG } & \text { Royal Thai Government } \\ \text { SEAC } & \text { Southeast Asia Command } \\ \text { SEANET } & \text { Southeast Asian Human Rights Network } \\ \text { SEANWFZ } & \text { Southeast Asian Nuclear Weapon Free Zone } \\ \text { SEATO } & \text { Southeast Asian Treaty Organisation } \\ \text { SNC } & \text { Supreme National Council } \\ \text { SOM } & \text { Senior Officials Meeting } \\ \text { SRV } & \text { Soviet Republic of Vietnam } \\ \text { TAC } & \text { Treaty of Amity and Cooperation } \\ \text { TNI } & \text { Tentara Nasional Indonesia (The Indonesian National } \\ & \text { Armed Forces) } \\ \text { TPP } & \text { Trans-Pacific Partnership } \\ \text { UDT } & \text { União Democratica Timorense (Timorese Democratic } \\ & \text { Union) } \\ \text { UMNO } & \text { United Malays National Organisation } \\ \text { UN } & \text { United Nations } \\ \text { UNAMET } & \text { United Nations Mission in East Timor } \\ \text { UNCLOS } & \text { United Nations Convention on the Law of the Sea } \\ \text { UNGA } & \text { United Nations General Assembly } \\ \text { UNMISET } & \text { United Nations Mission of Support in East Timor } \\ \text { UNSC } & \text { United Nations Security Council } \\ \text { UNTAET } & \text { United Nations Transitional Administration in East } \\ & \text { Timor } \\ \text { US } & \text { United States of America } \\ \text { USSR } & \text { Union of Soviet Socialist Republics } \\ \text { ZOPFAN } & \text { Zone of Peace, Freedom and Neutrality } \\ & \end{array}$





\section{Acknowledgements}

Primary thanks for this work go to Dr Nicholas Khoo, who is responsible for first sparking my interest in the Southeast Asian region over a decade ago. His extensive knowledge, excellent guidance and constructive feedback allowed this project to come into fruition. I would also like to thank the University of Otago, New Zealand for doctoral scholarship funding which allowed me to pursue this project, and the university politics department for providing a welcoming and stimulating academic environment in which to conduct my $\mathrm{PhD}$. Professor Robert Patman's role as informal mentor during this period was critical, and his advice continues to prove invaluable as I embark upon my career.

I am deeply indebted to the many friends who have offered words of encouragement and support when needed most. Particular mention goes to colleagues at the Centre for International Security and Resilience at Cranfield University, and the Politics and International Relations department at Aston University. I would also like to express my thanks to Bristol University Press editor Stephen Wenham, for recognising this project's worth and pushing it forward through the production process. Feedback from $\mathrm{PhD}$ examiners and book reviewers has proved vital, and the finished product is better for their constructive comments and suggestions.

This book wouldn't have been possible without the love and support of my partner Nik, who travelled to the other side of the world and back to join me on my PhD journey. This would mean little if not for him. The book is dedicated in loving memory of my parents.

Content from Chapters 1, 3 and 5 is originally published in Journal of Asian Security and International Affairs, Vol 2 No 2, and Journal of Asian Security and International Affairs, Vol 3 No 2, and appears here with thanks and permission of (C) SAGE Publications India Private Limited, New Delhi. 


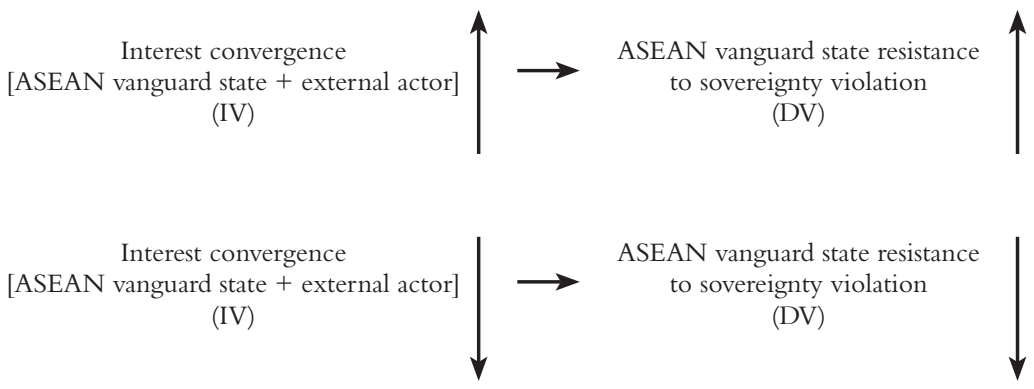

Note: $I V=$ Independent Variable DV $=$ Dependent Variable

Figure 1: The dynamics of ASEAN vanguard state resistance to sovereignty violation 


\title{
Introduction: ASEAN and the Vanguard State
}

\author{
Small countries have little power to alter the region, \\ let alone the world. A small country must seek a \\ maximum number of friends, while maintaining the \\ freedom to be itself as a sovereign and independent \\ nation. Both parts of the equation - a maximum \\ number of friends and freedom to be ourselves \\ - are equally important and interrelated. \\ Lee Kuan Yew, former Prime Minister of Singapore ${ }^{1}$
}

The Association of Southeast Asian Nations (ASEAN) is a regional institution founded in 1967 by the states of Indonesia, Malaysia, the Philippines, Singapore and Thailand. Growing to include Brunei in 1984, Vietnam in July 1995, Laos and Myanmar in July 1997, and Cambodia in April 1999, the institution has repeatedly defied expectations. Born out of the remnants of the Association of Southeast Asia (ASA) (1961-1967), a precursor regional institution frustrated by member state inability to overcome national and bloc interests, ${ }^{2}$ there was initially little hope that ASEAN would succeed where the ASA had failed. Yet ASEAN has transformed itself into arguably the most successful regional institution outside of Europe. This is particularly noteworthy in light of Southeast Asia's history of colonization and intervention, and the cultural, social, economic and political diversity that characterizes ASEAN's constitution.

\section{ASEAN's Cold War origins}

What are the reasons for ASEAN's conception in 1967? And how has this dictated ASEAN's policy and direction in the decades since its establishment? To understand the origins of ASEAN, an understanding 
of the history of the Southeast Asian region is crucial. The states that comprise the region understood as Southeast Asia are incredibly politically, socially, and culturally diverse, home to a variety of different ethnic and religious communities. This diversity created barriers between the different states in the region, with communication and cooperation historically difficult to initiate and sustain. ${ }^{3}$ So much so, that it was not until the Pacific War that the term 'Southeast Asia' entered common usage, when Western allies established a Southeast Asia Command (SEAC) to fight Japanese imperialism in 1943. ${ }^{4}$ This conflict coincided with the struggle of a number of regional states for independence from colonial rule. European powers first colonized the region in the 16th century, with only Thailand spared to act as a buffer state between British and French colonies. ${ }^{5}$ As a result of colonization, divisions between the countries were exacerbated, and each state's internal sociocultural dynamics inexorably altered. Nationalism was expressed in the form of armed struggles in Indonesia against the Dutch, and in Vietnam against the French. Between 1946 and the establishment of ASEAN in 1967, the majority of the region's states had gained their independence.

ASEAN is a product of this history and the colonial origins and legacies of its member states. As noted by Narine, 'the experience of colonialism deeply affected how the states of Southeast Asia perceived the regional environment' ${ }^{6}$ External states, particularly great powers, were viewed as interventionist and exploitative, and their motives regarded with suspicion. The advent of superpower rivalry between the United States (US), the Soviet Union and China solidified these views. By 1967, the international system was gripped by Cold War. Once again, the Southeast Asian region was divided, this time along ideological and political lines. Nowhere was this more apparent than in Vietnam, where a proxy conflict was waged between communist and anti-communist forces. Early attempts at establishing a regional organization in Southeast Asia proved unsuccessful. The Southeast Asian Treaty Organization (SEATO), formed in 1954, acted as a vehicle for external interests and lacked regional inclusivity. More inclusive organizations, such as the ASA, fell victim to regional state disputes. From 1962 to 1966, disagreements and conflicts between the region's states had hamstrung any efforts at cooperation. These disputes largely centred upon the proposed amalgamation of Malaya, Singapore, Sarawak, and Sabah into the Federation of Malaysia. Both the Philippines and Indonesia refused to recognize the new Federation. The Philippines disputed the territorial claim of Sabah. Indonesia denounced the influence of Britain, which it viewed as 'an imperial power imposing its will on Southeast Asia'? 
As a result, Indonesia embarked on a violent four-year campaign of Konfrontasi, or confrontation, with the newly federated state of Malaysia, growing to include Singapore following its forced separation from the federation in 1965. The campaign was only ended in 1966, when a power struggle between Indonesia's General Sukarno and General Suharto culminated in the latter successfully overthrowing the former's regime. With the new Indonesian General keen to enhance regional stability and reassure neighbours of the country's good intentions, the time seemed ripe for another attempt at regional cooperation. For the Philippines, Singapore and Thailand, a major factor in their support for a new regional organization was suspicion concerning Indonesia's potential regional ambitions. Through a new association, these states hoped to constrain Indonesia while offering protection for some of the smaller and more vulnerable regional states.

It is these events that paved the way for the establishment of ASEAN on 8 August 1967. Whilst the new Association was ostensibly 'a byproduct of institutionalized regional reconciliation,' there is little doubt that 'security was uppermost in their minds ... [if] not conspicuously addressed'. ${ }^{8}$ These security concerns were informed by the history of intervention in the region, weak domestic political structures vulnerable to insurgencies, separatism, and manipulation from external actors, and fear that US regional retrenchment might tip the balance of power in favour of the communist-controlled Soviet Union and North Vietnam. ASEAN's founding fathers defined the Association's aims in the 1967 Bangkok Declaration. These were to accelerate economic growth, social progress and cultural development in the region, to promote regional peace and stability through an abiding respect for the principles of the United Nations (UN) Charter, to promote active collaboration and mutual assistance on matters of mutual interest, and to maintain close cooperation with similar existing regional organizations. ${ }^{9}$ The Declaration's preamble refers to the Southeast Asian state's determination 'to ensure their stability from external interference in any form or manifestation'. ${ }^{10}$

Through ASEAN, the Southeast Asian states hoped to reduce intervention and military influence by external actors, foster regional state cooperation, and strengthen resilience against communist insurgencies. ${ }^{11}$ The Association's unique organizational structure, referred to as the 'ASEAN Way', has been credited with helping to bring together the diverse states of Southeast Asia by providing a conducive and non-threatening environment in which to discuss regional challenges. This consists of a preference for informal, consensus-based decision-making within a loosely structured and non- 
legalistic institution. For Leifer, it is only through the establishment of ASEAN that a 'conventional, if limited, coherence' developed in Southeast Asia. ${ }^{12}$ Analysis of ASEAN's Cold War regional role lends weight to this assessment. Between 1967 and 1991, the ASEAN states maintained a successful campaign to counter Vietnamese expansionism. These efforts took precedence over the pursuit of regional quarrels and bilateral state differences.

\section{ASEAN's post-Cold War relevance}

If ASEAN was established to manage Indonesia's regional ambitions and to strengthen the region against communist threat, why has it persisted beyond the Cold War environment in which it was established? Commitment to a post-Cold War regional order and deepening state cooperation has motivated the Southeast Asian states to expand ASEAN membership, and to promote its institutional model beyond the confines of the region. This has undoubtedly been driven by regional uncertainty over the future intentions of China. In view of China's geographic proximity and history of intervention in Southeast Asia, the ASEAN states hoped a consolidated Southeast Asian regionalism would 'strengthen the collective shield against China'. ${ }^{13}$ Inclusion of the former Soviet-proxy Vietnam into ASEAN in 1995, followed by Laos, Myanmar and Cambodia, represented an additional step towards this regional consolidation. For many observers of the region, ASEAN has since evolved into a credible regional and international actor. ASEAN's supporters credit the Association with a major role in ending the Cold War in Southeast Asia; successfully integrating Indonesia into the Southeast Asian region; managing interstate regional conflicts; robust growth, driven in part by the liberalization and structural reforms of its smaller, developing states; and successfully exporting its model of regionalism beyond the region's borders to enhance dialogue and cooperation with external states, as seen through initiatives such as the ASEAN Regional Forum (ARF). As summarized by Severino, 'ASEAN has achieved a certain degree of political solidarity, become a force for stability in the region, and managed to engage external powers constructively in Southeast Asian affairs'. ${ }^{14}$

ASEAN's critics dispute these claims and question the Association's coherence and relevance outside of the context of the Cold War. In this view, any successes have been overshadowed by the continued existence of territorial disputes between member-states; halting efforts at deeper economic integration; an ineffective and incoherent response 
to the Asian financial crisis of 1997; an inability or unwillingness to respond to a number of humanitarian crises that have originated from within the region; and a failure to prevent external actors from intervening in the region and dividing the Association. The ASEAN Way's emphasis on consensus 'has meant that the politics of the lowest common denominator has tended to prevail and difficult problems have been avoided rather than confronted'. ${ }^{15}$ For Weatherbee, on ASEAN's 'singularly important regional politics and security issues, rather than solidarity, there is disunion, and rather than common action, national self-interest determines policy choices'. ${ }^{16}$ This has been exacerbated by ASEAN expansion in the immediate post-Cold War period, and the inclusion of disparate states that each seek to pursue their own state interests.

ASEAN's endurance since the end of the Cold War has precipitated an extensive and contentious debate. The degree to which the Association has achieved the aims codified in the Bangkok Declaration, and remained relevant in the contemporary international system, is contested. These debates hinge upon broader themes of state autonomy, regional order, and the role and purpose of regional organizations. As is argued here, these themes can be addressed alongside those of ASEAN's origins and future, through deeper analysis of the Association and its responses to intervention.

\section{Questioning ASEAN resistance to sovereignty violation}

This book addresses this history of external interference in Southeast Asia, through analysis of the ability of regional states to resist sovereignty violation from external powers. It answers one central question: when has ASEAN state resistance to sovereignty violation succeeded, and when has it failed? In addressing this question, the book analyses past instances of (non)resistance to sovereignty violation, considers the degree to which the Association has realized its founding aim of stability from external intervention, and provides a predictive tool that can be used for future interactions between ASEAN member states and external states. Southeast Asia's experience of intervention is still relevant today. The region remains of geopolitical importance for great powers, and future interventions cannot be ruled out. An understanding of the ways in which these regional states utilize state and institutional balancing and bargaining strategies to help defend state sovereignty and territorial integrity is therefore critical. 
ASEAN state preoccupation with resisting intervention and upholding state sovereignty cannot be overemphasized. ASEAN's 1976 Treaty of Amity and Cooperation (TAC) in Southeast Asia codifies a number of principles designed to structure relations within the institution, and with actors external to the region. These principles continue to dominate ASEAN's practice. The TAC contains articles that refer to ASEAN's territorial integrity and sovereignty, noninterference in the internal affairs of member states, and the principle that 'every state [has the right] to lead its national existence free from external interference, subversion or coercion' ${ }^{17}$ It is important to note that this final principle is not unique to ASEAN. The UN Charter endorses this concept of sovereignty by confirming 'the principle of the sovereign equality of all its members'. ${ }^{18}$ This article of the TAC is based on this conception of sovereignty, which stresses, 'territoriality and the exclusion of external actors from domestic authority structures'. ${ }^{19}$ For many, the principle of non-intervention is the key element of sovereign statehood. ${ }^{20}$ Despite the centrality of the principle of sovereignty, it has often been contravened, with external actor intervention the most common form of sovereignty violation. Because powerful states often intervene in the internal affairs of less powerful states, the latter have always been the strongest supporters of the rule of non-intervention. ${ }^{21}$ The difficulty for small states lies in their ability to uphold this principle. This is something that this book addresses directly, through analysis of the different mechanisms for resistance available to ASEAN member states.

The book addresses a number of important questions pertaining to ASEAN, its characteristics, and its member state behaviour since inception. It considers the degree to which a group of small, vulnerable regional states are able to exercise autonomy, and continue to survive in an environment dominated by great powers. This includes an investigation into the potential role of ASEAN as an organization, both regionally and internationally, with a specific focus on ASEAN's ability to uphold regional order, and engage in regional conflict and dispute resolution. The analysis brings to the fore the impact of state membership within the institution during times of conflict. Rather than view ASEAN as a monolithic entity, the book engages in a deeper assessment of the interaction and behavioural patterns of ASEAN member states during periods of regional and international crisis. This process unveils the complexities of regional state relationships, both internally and with external powers, in addition to inter-organizational power dynamics and the resulting impact that these have in dictating ASEAN policy. 


\section{An introduction to existing ASEAN scholarship}

ASEAN's ability to resist sovereignty violation and defend regional autonomy from external intervention is contested within the existing ASEAN scholarship. Since the turn of the 21st century, the most prominent of these bodies of literature is that which is most closely aligned to the constructivist school of thought. ${ }^{22}$ Constructivist authors emphasize ASEAN state autonomy, the transformative power of ASEAN's norms, the socializing impact that these norms have on member state identities and behaviours, and ASEAN's ability to uphold regional order, even when directly challenged. Constructivist scholarly works employ a breadth of variables, ranging from norms to culture, identity and ideas, to understand and explain ASEAN's ability to uphold sovereignty and resist intervention. The strengths of this argument lie in the desire to look beyond the impact of material forces to explain ASEAN's deepening cooperation and resilience since the end of the Cold War.

Taking an alternative approach to that described above are works most closely aligned with realist theory. ${ }^{23}$ A realist approach to Southeast Asian regionalism is predicated on state centricity, the critical role of the US in maintaining a regional balance of power, and state concern with self-interest and zero-sum bargaining. Unlike the argument presented by the constructivists, these scholars take a less positive view of ASEAN autonomy. Instead, ASEAN's ability to resist sovereignty violation is wholly contingent upon the actions of great powers. In their explicit challenge to constructivist theorizing, they have opened and widened the debate on Southeast Asian regionalism. The arguments these authors present are compelling. Rooted in material explanations and using structural variables, they provide a view of the Southeast Asian region that goes beyond the domestic level, to consider the influential role of great powers.

In a more recent addition to the literature, the critical theoretical approach emphasizes state contestation, the scope of political conflict, and the struggles between and within Southeast Asia's social forces. ${ }^{24}$ This critical approach to Southeast Asian regional order provides an alternative theoretical account that stands apart from the constructivistrealist debate. Its strengths lie in its non-statist approach, which allows greater emphasis for the role of domestic groups, their interests and their interactions. In doing so, it provides an explanation for ASEAN's mixed record of non-interference and intervention in a way that existing accounts of the region lack. This book engages with these different scholarly explanations for ASEAN's ability to defend regional 
autonomy and resist intervention. By analysing the strengths and weaknesses of these arguments, it highlights the gaps evident in the literature upon which vanguard state theory seeks to build. In doing so, it presents a theory that both complements and advances the existing account of ASEAN resistance to sovereignty violation.

\section{Explaining ASEAN resistance to sovereignty violation}

The argument presented here occupies a middle ground within existing ASEAN scholarship. ASEAN's history is understood according to a realist theoretical logic, in terms of the relationship between an ASEAN 'vanguard state' and selected external powers. A 'vanguard state' is defined as an ASEAN state that comes to the fore of the Association when it has vital interests at stake that it wishes to pursue. While a state's interests may vary, vital interests relate to state survival and the preservation of state sovereignty. An ASEAN state only begins to assume the role of vanguard when state security is threatened. This study contends that a convergence in interests between an ASEAN vanguard state and an external actor will cause the success of ASEAN vanguard state resistance to sovereignty violation (see Figure 1). When an ASEAN vanguard state has interests that converge with those of an external power, it has an active and substantial role in resisting sovereignty violation. In addition to seeking external power guarantees, a vanguard state will also seek to secure its own interests within the Association. It will do so by attempting to set ASEAN's agenda, by garnering great power security commitments, and seeking to portray a united ASEAN front in support of vanguard state policy. Conversely, an absence of interest convergence between the ASEAN vanguard state and a designated external actor will cause the failure of ASEAN vanguard state (and by extension ASEAN) resistance to sovereignty violation. While the ASEAN vanguard state clearly has an important role to play in preventing external actor intervention, an equally important factor explaining ASEAN resistance to sovereignty violation resides in the critical role played by selected external powers. Indeed, this study shows how ASEAN is unable to resist challenges to its sovereignty when its interests do not converge with those of an external actor.

This argument contains a number of strengths that together offer a contribution to the field. First, by focusing on both the roles of, and interrelationship between, regional states and external actors, 
it offers a more expansive argument for resistance to sovereignty violation than currently exists in the ASEAN literature. Additionally, through the creation of a 'vanguard state' concept, it provides a new theory that allows the reader to reconsider individual and group state behaviour within a regional organization, particularly as it pertains to foreign policy strategy, and to re-evaluate the impact of regional institutional membership for state security and survival. To support the theory presented here, an array of primary source information has been collected covering a time span from 1975 to present day. This information provides a comprehensive account of shifting state interests, both within ASEAN and of states external to the region, and the impact of varying interest convergence on ASEAN-state security and territorial integrity.

\section{Outline of the book}

The book comprises six chapters. Chapter 1 explores in more depth the contending arguments for sovereignty violation in Southeast Asia. It highlights the ways in which constructivist, realist and critical theorists have approached the topic of ASEAN regionalism and member state autonomy, followed by an introduction to vanguard state theory and the ways in which the argument presented can build upon existing literature. Chapters 2 to 5 provide in-depth case study analysis of ASEAN's mixed resistance to sovereignty violation, both during the Cold War and in the post-Cold War period. This begins with an analysis of the Indonesian invasion of East Timor in 1975, providing evidence to show how the Cold War regional environment created a convergence of interests between Indonesia, the ASEAN vanguard state, the US and Australia regarding the newly decolonized territory of East Timor. With external and regional power backing, Indonesia was able to invade East Timor without any repercussions from the international community, despite considerable attempts by the UN to intervene in Indonesia's internal affairs to allow the East Timorese an act of self-determination.

Continuing the examination of the Cold War period, Chapter 3 reviews the events of the Third Indochina War between 1978 and 1991. Analysis of recently declassified US documents helps shed light on the informal alliance that developed between Thailand, China, the ASEAN states, the ousted Khmer Rouge, and to a lesser extent the US, in an effort to contain Vietnamese and Soviet influence in Southeast Asia following Vietnam's invasion of Cambodia in 1978. As 
a consequence of high interest convergence between Thailand and a designated external power, China, ASEAN was able to resist violations to the sovereignty of Thailand from a Soviet-backed Vietnam. This brings us to the beginning of the post-Cold War period, with Chapter 4 analysing the East Timor humanitarian crisis of 1999. It shows how interest divergence between Indonesia, the US and Australia, following the 1997 Asian Financial Crisis, led to external powers applying pressure on Indonesia to elicit regime change in East Timor. In a weakened state, Indonesia was coerced into accepting an international peacekeeping force in East Timor, despite asserting that such a force would constitute an unacceptable breach of its state sovereignty. Critically, ASEAN institutional cohesion alone was not sufficient to prevent Indonesian sovereignty violation at this time.

The final case study chapter analyses the South China Sea dispute from 1992 to present day. It shows how partial interest convergence between the Philippines, Vietnam and the US has been insufficient to prevent these dual vanguard states from having their maritime sovereignty violated by an assertive China. Through the analysis of three separate time periods, 1992-2012, 2012-2016, and 2016 to present, the chapter traces the varying levels of interest convergence and intra-ASEAN cohesion, both of which have failed to reach the robust levels required to satisfy vanguard state theory. The book concludes by analysing the research findings to provide a definitive response to the central research question advanced here. In doing so, it assesses the applicability of vanguard state theory to sovereignty violation in Southeast Asia, and concludes by considering the potential effects of humanitarian intervention and the Responsibility to Protect (R2P) on the future of ASEAN sovereignty.

\section{Notes}

1 Speech by Mr Lee Kuan Yew, Minister Mentor, at the S Rajaratnam Lecture, 09 April 2009, 5.30pm at Shangri-La Hotel, Prime Minister's Office Singapore, https://www.pmo.gov.sg/newsroom/speech-mr-lee-kuan-yewminister-mentor-s-rajaratnam-lecture-09-april-2009-530-pm-shangri.

2 Vincent K Pollard, “ASA and ASEAN, 1961-1967: Southeast Asian Regionalism”, Asian Survey 10, no. 3 (1970), 254.

3 Shaun Narine, Explaining ASEAN: Regionalism in Southeast Asia (Lynne Rienner Publishers: London, 2002), 9.

4 Michael Leifer, "Southeast Asia", in The Oxford History of the Twentieth Century, ed. Michael Howard and Wm. Roger Louis (Oxford: Oxford University Press, 1998), 227-8.

5 Leifer, "Southeast Asia", 227-8. 
6 Narine, Explaining ASEAN, 10.

7 Narine, Explaining ASEAN, 12.

8 Michael Leifer, ASEAN and the Security of South-East Asia (London: Routledge, 1989), vii.

9 The Association of Southeast Asian Nations (ASEAN) Bangkok Declaration, Bangkok 8 August 1967, http://asean.org/the-aseandeclaration-bangkok-declaration-bangkok-8-august-1967/.

10 ASEAN Bangkok Declaration, Bangkok 8 August 1967.

11 Narine, Explaining ASEAN, 13.

12 Kin Wah Chin and Leo Suryadinata, ed. Michael Leifer: Selected Works on Southeast Asia. (Singapore: Institute of Southeast Asian Studies, 2005), 1.

13 Leszek Buszynski, "Southeast Asia in the Post-Cold War Era: Regionalism and Security", Asian Survey 32, no. 9 (1992), 833.

14 Rodolfo Severino, "ASEAN Beyond Forty: Towards Political and Economic Integration”, Contemporary Southeast Asia 29, no. 3 (2007), 422.

15 Mark Beeson, Can ASEAN Cope with China?" Journal of Current Southeast Asian Affairs 35, no. 1 (2016), 10.

16 Donald Weatherbee, "Southeast Asia and ASEAN: Running in Place", Southeast Asian Affairs (2012), 20

17 ASEAN, Treaty of Amity and Cooperation in Southeast Asia, Article 2(b). See http://www.asean.org/news/item/treaty-of-amity-and-cooperationin-southeast-asia-indonesia-24-february-1976-3.

18 United Nations Charter, "Chapter I: Purposes and Principles", Article 2(1).

19 Stephen Krasner, Sovereignty: Organized Hypocrisy (Princeton: Princeton University Press, 1999), 20.

20 Krasner, Sovereignty: Organized Hypocrisy, 20.

21 Krasner, Sovereignty: Organized Hypocrisy, 21.

22 Amitav Acharya, Constructing a Security Community in Southeast Asia. 3rd ed. (Hoboken: Taylor \& Francis, 2014); Amitav Acharya, The Making of Southeast Asia (New York: Cornell University Press, 2012); Amitav Acharya, Whose Ideas Matter? (New York: Cornell University Press, 2009); Alice Ba, [Re]Negotiating East and Southeast Asia (Stanford: Stanford University Press, 2009); Jürgen Haacke, ASEAN'S Diplomatic And Security Culture (London: RoutledgeCurzon, 2003).

23 David M Jones and Michael LR Smith, "Constructing Communities: The Curious Case of East Asian Regionalism”, Review of International Studies 33, no. 1 (2007): 165-186; David M Jones and Michael L Smith, "Making Process, Not Progress", International Security 32, no. 1 (Summer 2007): 148-184; David M Jones and Michael LR Smith, ASEAN and East Asian International Relations: Regional Delusion (Cheltenham: Edward Elgar, 2006); David M Jones and Michael LR Smith, “ASEAN's Imitation 
Community", ORBIS 46, no. 1 (Winter 2002): 93-109; Michael Leifer, ASEAN and the Security of South-East Asia (London: Routledge, 1989).

24 Lee Jones, "Sovereignty, intervention, and social order in revolutionary times", Review of International Studies 39, no. 1 (2013): 1149-1167; Lee Jones, ASEAN, Sovereignty and Intervention in Southeast Asia (New York: Palgrave Macmillan, 2012). 


\section{Interests and Vanguard State Theory ${ }^{1}$}

The existing literature regarding ASEAN's record on sovereignty violation is polarized. Over the last two decades, a highly influential group of theorists associated closely with the constructivist perspective has emphasized ASEAN's autonomy and ability to uphold regional order despite challenges. A second perspective has been advanced by theorists of a realist persuasion, who emphasize ASEAN's lack of autonomy in the face of sovereignty challenges, and reliance on external actors' sufferance. Finally, a third approach, associated with critical theory, explains ASEAN's record on sovereignty as a function of social forces within individual ASEAN states. This study attempts to contribute to the literature by advancing a fourth perspective, also rooted in realist theory, where ASEAN's record is highly dependent on the stance of external actors whose interests align with those of the organizations.

\section{Constructivist theory: the power of norms and ideas}

For the past two decades, a number of influential constructivist works have sought to understand and explain the prolonged period of relative peace evident in Southeast Asia since the conception of ASEAN. For these scholars, ASEAN's continued growth in the aftermath of the Cold War cannot be explained by balance of power politics or selfhelp behaviour. Rather, ASEAN's historical experience, identity and norms of behaviour have played a crucial role in enhancing regional peace and cooperation. The strength of this approach is that it seeks to understand ASEAN regionalism on an ideational, rather than material 
footing, thus adding depth to the regional debate. However, a closer assessment of the literature highlights limitations, upon which this account seeks to build.

\section{Institutional cooperation and coercion}

Constructivists argue that norms have a transformative impact, regulating state behaviour, redefining state interests and constituting state identities. ${ }^{2}$ In this view, ASEAN norms are inherently cooperative and benign. In only considering cooperative norms, however, constructivists who have traditionally analyzed ASEAN are unable to adequately explain variance in Southeast Asia's international relations. This is an important point, as evidence strongly suggests that ASEAN's cooperative norms are routinely violated by all member states. For example, the norms of regional autonomy and non-interference have both been compromised. ASEAN allied itself with China in its containment policy of Vietnam following its invasion of Cambodia. Indonesia's annexation of East Timor and the ensuing 27-year conflict and humanitarian crisis was largely met with ASEAN disunity and apathy. As Khoo states, 'it would appear that focusing on "perverse norms" would go a long way to explain ASEAN's international relations, particularly after the Cold War'. ${ }^{3}$

A related point is that the constructivist literature on Southeast Asia's international relations is overly focused on institutions as venues for cooperation, whereby ASEAN's norms have a socializing effect on external powers, heralding a wider East Asian regional order modelled on Southeast Asian regionalism. ${ }^{4}$ Unfortunately, this minimizes the role of coercive power dynamics in institutions. Acknowledging these problems in the literature, recent work by Glas addresses the absence of war between ASEAN members in light of the region's on-going militarized disputes. Through a focus on practices and habits of regional relations, understood as 'habits of peace' shaped prior to reflection, Glas explains patterns of conflict and cooperation in the Southeast Asian region. ${ }^{5}$ These habitual practices relate to a number of different Southeast Asian attributes, including the practice of consensus, informal decision-making and dispute settlement, and substantiated by thinking on non-interference, member state equality, and face-saving.

Glas' argument is persuasive, but not without challenges. It is unclear from where and when these habits originated, and whether they apply evenly across actors despite the different timeframes of ASEAN state 
membership. Most important is the author's acknowledgment of the challenge posed in recognizing habitual behaviour, which by definition lacks reflective thinking. ${ }^{6}$ Due to the difficulties associated with pinpointing habitual behaviour from other forms of cognitive practice, Glas leaves room for a rationalistic, interest-driven interpretation of actor behaviour. This is particularly the case when responding to security threats. While Glas argues that 'habitual practices temper how states perceive risks and circumscribe responses to crises', ${ }^{7}$ the case of the Thai-Cambodian border dispute would suggest otherwise. In this case, Cambodia broke with the ASEAN habit of non-interference when it approached the UN Security Council for assistance to resolve the dispute. This difficulty in identifying interest from habit suggests a more complicated process of regional relations than the author allows for.

From a realist perspective, power and interests are fundamental to the study of institutions. Here, small states can act in concert to secure their interests. As Schweller and Priess argue, 'actors that gain power within an institution have the ability to set its agenda and influence the distribution of benefits and costs among members'. According to Mansfield, 'states and interest groups have an incentive to capture international institutions because they can generate power for those that control them. Actors that gain power within an institution have the ability to set its agenda'. Institutions are therefore arenas, where states respond to incentives and work to secure their interests. As will be illustrated in our study, great powers frequently have leverage over smaller states. Gruber argues that weaker states voluntarily cooperate within institutions because they have 'no better option'. ${ }^{10}$ Cooperation and power are therefore mutually reinforcing. ${ }^{11}$ An appreciation of this realist literature on institutions suggests that the constructivist overemphasis on positive cooperation and inability to discount rationalistic behaviour offers an incomplete picture of international relations.

\section{Problematic variables: the role of norms and ideas}

The strength of a causal argument rests in large part on the degree of rigour that has attended the conceptualization of its variables. In Constructing a Security Community in Southeast Asia, Acharya focuses on institutions, norms and the process of identity building in the making of a security community. The author confirms his independent variable to be norms. ${ }^{12}$ The dependent variable is the construction of a security community. Identity acts as a 'central explanatory tool in the making and unmaking of security communities'. ${ }^{13}$ However, the way 
in which identity affects the dependent variable is not clear. Acharya is not specific as to whether identity acts as an intervening variable or an independent variable, and as such it is unclear where identity fits into his causal argument. This leaves his argument ambiguous. In Whose Ideas Matter? Acharya formulates two diagrams in which he confirms his intervening variable to be regional cognitive priors, created when certain external ideas or norms resonate with leaders. ${ }^{14}$ Acharya confirms the dependent variable to be institutional design and change. However, the independent variable differs between diagrams. Firstly, it is stated as 'ideas and norms', secondly as 'transnational norms'. This conflation of different concepts results in an independent variable that lacks conceptual clarity. A similar problem exists in Jürgen Haacke's ASEAN's Diplomatic and Security Culture. Rather than identifying a causal argument, Haacke employs a proliferation of key constructivist concepts as variables. In this respect, ASEAN norms have been reconceptualized as a diplomatic and security culture, making norms and culture interchangeable concepts. ${ }^{15}$ While Haacke uses the terminology of culture, his focus is on norms. This creates problems with respect to the clarity of his argument.

Ba confirms that founding ideas about Southeast Asia led to the 'collective pursuit of regional resilience vis-à-vis outside forces'. ${ }^{16}$ Ba's independent variable is ideas, and her dependent variable is a process of socialization. In this view, discourse and the exchange of ideas can change state behaviour. However, as Mearsheimer argues, 'changes in the material world drive changes in discourse'. ${ }^{17}$ Discourse therefore, 'turns out not to be determinative, but mainly a reflection of developments in the objective world'. ${ }^{18}$ Thies also highlights the Kenneth Waltz argument, that structure shapes and constrains the units of the system through competition and socialization. ${ }^{19}$ As such, 'the process of interstate interaction is structured by socialization operating on behalf of anarchy and the distribution of capabilities' ${ }^{20}$ By incorporating socialization into its explanation of structure, neorealism is able to account for the impact of both material and ideational factors on state behaviour. What Ba believes are core concepts driving events are actually determined by variables from realism, a rival theory to her theoretical framework.

The above analysis highlights the difficulty inherent in conceptualizing constructivist norms. This makes it increasingly difficult to observe the potential impact of norms and their role in shaping state behaviour or changing state practice. A recent edited collection by Betts and Orchard takes steps to address this problem in the literature. For the authors, existing theory has predominantly focused on the process 
of institutionalization, understood as the international process by which norms emerge at the international level. ${ }^{21}$ How norms play out in practice, and the normative political contestation that occurs at the domestic level, is under-theorized, resulting in a 'normative institutionalization-implementation gap'. ${ }^{22}$ The authors address this gap by developing the concept of 'implementation'. They identify a number of causal mechanisms that can either constrain or constitute implementation efforts, including ideational, material and institutional domestic factors. Critically, such an approach allows for a variety of structural factors, in addition to allowing a role for domestic or international actors and the influence they also exert. The result is a theory that explains variation in norm compliance and state practices.

Betts and Orchard's argument advances the constructivist analysis of norms. Aspects remain under-theorized, however, providing space for an alternative approach to state behaviour. For instance, it isn't clear from the narrative exactly how implementation can be observed, how variance in implementation can be measured, and at what stage implementation can be said to have occurred. Indeed, the authors suggest that the implementation process may have no clear end point', and that 'norms are never fixed'. ${ }^{23}$ The authors also contend that "implementation draws our attention to a crucial part of the causal process through which norms are "effective" or not in their outcomes'. ${ }^{24}$ Exactly what an effective outcome looks like isn't clear. If we consider the ASEAN norm of non-interference for instance, its effectiveness is largely open to contention. The edited collection does not theorize on the ASEAN case, and it is not always apparent where some of ASEAN's more unique norms or practices sit within Betts and Orchard's theory. The authors delineate norms under one of three categories: treaty norms, principle norms and policy norms, although it is less apparent how norms are attributed to such categories. The authors also state that "bureaucratic contestation is likely to define which aspects of norms are successfully implemented and which fall by the wayside'. ${ }^{25}$ How this then applies to ASEAN, which lacks a bureaucratic structure, is unclear.

Of most interest is the author's inclusion of material causal factors, an approach that recognizes the important role that both interests and external actors play in shaping norms. As the authors confirm, 'imprecise and ambiguous norms are likely to be interpreted (and hence applied) through the lenses of parochial sets of interests and reconciled through power'. ${ }^{26}$ This represents an advance on the work of Acharya, whose focus on local actor norm localization marginalizes such factors. A number of works in the edited collection provide a 
material-based account. Betts utilizes the concept of regime to consider the way, in which norms can be reconciled through interests at the national level. ${ }^{27}$ Job and Shesterinina, on the other hand, consider the role of China in shaping the R2P norm in light of its adherence to state sovereignty. ${ }^{28}$ Similarly, Aneja provides an actor-driven account of the implementation of the needs-based assistance norm. ${ }^{29}$ These represent an important step, yet a gap remains. Whilst interests have a causal role, they remain under-theorized, and lack any real analysis of how interests can be defined or interest variance measured. It can also be argued that actors are given too much power in the implementation process, with the impact of structural constraints on state practices neglected. Ultimately, these are areas that this study will seek to contribute, to provide a better understanding of both domestic and external actor interests and the international environment in which they interact.

\section{Realist theory: US influence and the balance of power}

The standard realist perspective represents another strand in the literature. If the constructivist literature has overemphasized ASEAN's ability to resist sovereignty violations, then this strand in the literature sees little agency for ASEAN in regional affairs. According to Leifer, the notion of 'regional solutions to regional problems' is inherently flawed, for two important reasons. First, the notion neglects the prospect of regional differences over strategic perspectives. Second, the notion 'assumes that a regional association can solve problems, whereas any degree of institutional success in Pacific Asia since the Second World War has depended on conspicuously avoiding a problem-solving role'. ${ }^{30}$ Leifer specifically focuses on the ARF, which he argues 'has reflected the condition of the more important regional relationships and, in particular, that between the US and China'. 31 This has made achieving regional solutions for regional problems 'more a myth than a valid aspiration'. ${ }^{32}$ Leifer's approach places significant emphasis on the role of extra-regional powers, minimizing ASEAN's role in its search for regional autonomy.

Responding to the constructivist literature on Southeast Asian regionalism, Jones and Smith believe that constructivist scholarship has misrepresented the underlying characteristics of ASEAN, which actually conform to power-political realities. Thus, in order to enhance state security, ASEAN states have engaged in classic balance of power politics, specifically the retaining of 'US influence in the Asia-Pacific 
to offset the rising power of China'. ${ }^{33}$ Significantly, Jones and Smith claim that ASEAN's preference for consensus and conflict avoidance has lent itself to extra-regional actors manipulating ASEAN norms to serve their own best interests. ${ }^{34}$ As such, extreme caution should be exercised when attempting to expand ASEAN's regional project onto a wider regional canvas. ${ }^{35}$

The realist analysis offers a strong counter-argument to constructivist thinking. However, empirical evidence suggests that there are aspects of this analysis that should give us pause. In the realist view described above, the ASEAN states are portrayed as 'ultimately dependent upon the continued American security commitments'. ${ }^{36}$ While external powers such as the United States clearly play an important role in the region, this view arguably goes too far, and unhelpfully obscures the role of regional states. Indeed, evidence which has emerged relatively recently from the US State Department archives confirms that Indonesia adeptly exploited US fears of communism to secure its own interests with respect to East Timor, ${ }^{37}$ and that it did so with ASEAN backing. ${ }^{38}$ This implies a greater role for Indonesia than is acknowledged in the current realist argument.

The existing realist analysis of the Third Indochina War displays a similar problem. For these scholars, the conflict was an archetypal example of great powers using regional states to secure their own interests. In this respect, ASEAN was a 'convenient front for external actors', ${ }^{39}$ adopting a position that 'favoured China's interests, above all'. ${ }^{40}$ While it is clear that external powers sought to secure their interests during this conflict, this approach minimizes the important role played by regional states. In seeking to secure its own interests, Thailand arguably played a greater role in the conflict than is evident in the current realist analysis. Certainly, China viewed Thailand, and ASEAN, as a vital component in its strategy to contain the Vietnamese. ${ }^{41}$ The empirical evidence suggests that the view advanced by Leifer, Jones and Smith contains limitations, which I seek to rectify. The authors offer a strong counter-argument, whereby ASEAN states have very little autonomy, and rely on external powers to maintain regional order. However, in taking a restrictive view of ASEAN autonomy, Leifer, Jones and Smith are unable to convincingly explain examples of ASEAN state cooperation, consensus and resistance to external intervention. 


\section{Critical theory: the power of social forces}

A new approach to sovereignty and intervention in Southeast Asia is provided in the work of Jones, who transcends the constructivist-realist debate by proffering an argument broadly categorized as a critical theoretical approach, one which is closely aligned to materialist state theory and social conflict theory. A relatively recent addition to the literature, Jones highlights inconsistencies within the existing debate on the ASEAN norm of non-interference, which many scholars believe has been upheld despite evidence to the contrary. Seeking to explain ASEAN's mixed record of intervention and non-interference, Jones advances a perspective where 'intervention and the non-interference principle can be explained as the outcome of struggles between and within ASEAN's most powerful social forces'. ${ }^{42}$

For Jones, sovereignty and non-interference can be analyzed as a 'technology of power' mechanism, which is used by domestic groups to help determine the scope of political conflict in a way that best suits their needs. ${ }^{43}$ Because of this 'intimate relationship between sovereignty and social order', sovereignty is always subject to contestation by socio-political forces. ${ }^{44}$ According to Jones, the state and its institutions support the owners of capital in their domestic conflicts. By invoking the non-interference norm, state actors are able to contain socio-political conflict within a specific region, and exclude outside influences that may wish to aid social groups in their control for state power. However, state actors will also violate this norm when they perceive any external threat. Non-interference can therefore be invoked or discarded to suit particular interests or strategies.

There is much to Jones' argument to engage with, beginning with his conceptualization of the role of the state. According to this view, 'power is not some thing or capacity vested in state apparatuses but rather is widely dispersed ... among many different social forces, such as classes and class fractions'. ${ }^{45}$ States are therefore viewed as complex, rather than coherent, exhibiting a variety of internal divisions. This approach to the state is also evident in a more recent analysis of governance in Southeast Asia provided by Gerard, who 'conceptualizes states as complex social relations, meaning their form is structured through conflicts between social forces seeking to advance their interests at the expense of others' ${ }^{46}$ Such approaches challenge the neo-Weberian view of the state as a 'black box', as favoured by traditional International Relations scholars. Indeed, for neorealists, constraints imposed by the international system create the same basic incentives for all states, making domestic variables such as regime or 
leadership type of little importance. ${ }^{47}$ However, more recent works associated with the realist school have sought to open the black box of the state by connecting external and internal variables. These approaches show the way in which unit level variables, such as domestic constraints or elite interests, can function as intervening variables to explain the relationship between the relative distribution of power in the international system and the foreign policies of states. ${ }^{48}$ While 'ideal state behaviour is that which conforms with the unitary actor', there are times when these conditions are not met due to domestic variables. ${ }^{49}$ Crucially, 'when systemic constraints are ignored, foreign policy failure results ... [and] the system punishes'. ${ }^{50}$ Jones' analysis, with its preferential focus on internal social forces, de-emphasizes external variables such as systemic constraints and the distribution of power. Arguably, he therefore provides an incomplete picture of the state and its role in the international system.

Jones explores the relationship between sovereignty and intervention by reconceptualizing both as a 'technology as power'. This allows for the identification of patterns of sovereignty and intervention, with sovereignty continuously contested by social forces. The end product is shaped by this struggle and then conditioned by local and global geopolitical factors. This raises the question of whether this is a two-way process, with external geopolitical factors also conditioning the domestic sphere. If so, a countering argument could be made, whereby the external forces actually shape and condition the domestic relations. It is clear that Jones' argument has a role for external actors, with successful sovereignty claims depending upon 'prevailing constellations of power [and] interests ... at the international level', and with rival social forces potentially 'supported by different external agents' ${ }^{51}$ However, the interests of these external actors are subservient to that of internal social forces, which are the 'fundamental drivers' of sovereignty regimes. These external forces therefore play a conditioning, rather than causal role, in sovereignty and intervention. ${ }^{52}$ The argument presented here will redress this imbalance, to show how in reality these external actors play a much more crucial role in Southeast Asian sovereignty and intervention than is currently allowed for.

In doing so, it will provide a deeper conceptual analysis of how interests are measured and defined, something implicit in Jones' analysis rather than explicit. It will also consider the important role for consensus and cooperation between internal and external actors for the maintenance of political authority, in addition to the instances of conflict that undoubtedly occur. In this respect, a more positive view 
of sovereignty will be offered, beyond Jones' analysis of a 'conflictridden process', which requires 'tremendous amounts of violence'. ${ }^{53}$ While the author agrees with Jones that 'violent clashes of interest', 54 occur in territorializing sovereign states, it will be contended that this is only part of the picture, and minimizes the instances of interest convergence which can also occur. This project will therefore seek to build on the work done by Jones, and consider the actions that ASEAN member states can take to resist violations to their sovereignty. Emphasis on state ability to resist sovereignty violation, as opposed to explanations for when sovereignty is or is not transgressed, provides a predictive, rather than historic, analysis. According to this approach, there is little point seeking to explain why certain states have been singled out for intervention. This is because external intervention in the affairs of weaker states is driven by geopolitical events dictated by the structure of the international system and the actions of great powers. Instances of intervention sit outside of the control of smaller, weaker powers, which must always assume the worst and prepare themselves accordingly. This analysis rests upon their ability to do so. The result is a dynamic theory that seeks to explain how, why and when states cooperate in light of conflicting regional and international state interests and power dynamics.

\section{Contribution to the realist debate}

Vanguard state theory will build upon existing arguments, to offer a theory that can explain the mixed record of sovereignty violation in Southeast Asia through a focus on Southeast Asian and external power interest convergence. In doing so, it contributes to the current realist regional and institutional literature. Realist authors Joseph Grieco ${ }^{55}$ and Gil Merom ${ }^{56}$ attempt to enhance realist explanatory power in relation to institutional and regional analysis. For Grieco, neorealist thought is notably lacking in its ability to explain weak member state behaviour within international institutions. However, neorealism can be 'amended to ascribe significance to international institutions' by including a 'voice opportunities thesis'. 57 According to this approach, weaker states are able to voice concerns regarding stronger powers and any unfair divisions of gains. This helps strengthen weak power influence over stronger powers. Taking a different approach, Merom attempts to address 'the regional void in realism' by explaining the significance of regional order from a realist stance. ${ }^{58} \mathrm{He}$ does this by suggesting two amendments to the theory: 'contingent realism', 
which widens the scope of realism beyond the distribution of power to include unit-level variables; and 'constructive realism', ${ }^{59}$ which introduces the logic of constructivism to help explain prolonged periods of peace and regional society building.

These are important steps towards enhancing realist explanatory power. Merom and Grieco's work is a useful entry point by realists into the regional literature. However, neither Grieco nor Merom have succeeded in producing fully developed or testable theoretical amendments. Grieco has posited his 'voice opportunities thesis' in relation to Europe's Economic and Monetary Union (EMU) rule trajectory only. It is not clear whether this can be applied to a Third World institution, or could be moved out of the sphere of international political economy and into the field of security studies. Merom advances a theoretical framework only, using a brief discussion of the Middle East to highlight his amendments. While this study will attempt to integrate with this literature, a gap remains to explore a realist understanding of regionalism which is supported by strong case study analysis.

To that end, this book will seek to develop a theory of sovereignty and intervention in Southeast Asia that incorporates foreign policy strategy based on the assumptions of realist theory. This is in accordance with the work of Colin Elman, who argues that we can use neorealism as a theory of foreign policy, which 'makes determinate predications for dependent variable(s) that measure the behaviour of individual states'. ${ }^{60}$ In doing so, it will seek to contribute to the literature on small states from a realist perspective, where states are conceptualized as unitary and rational actors. ${ }^{61}$ By adopting a realist-based theoretical approach, this book seeks to advance an argument that looks beyond ASEAN adherence to norms and the role of social forces, to explain the mixed record of ASEAN state resistance to sovereignty violation. In determining the dynamics of ASEAN resistance to sovereignty violation, two variables present themselves: interest convergence and success of resistance to sovereignty violation (see Figure 1 for diagram).

\section{Delineating our variables}

For the purpose of this study, the independent variable is interest convergence between an ASEAN vanguard state and an external actor. A vanguard state is a regional state with the most compelling interests at stake in a given issue. Vanguard state theory does not preclude there being more than one vanguard state. In the event of two or more 
vanguard states, the same criteria apply. States must have the same compelling interests at stake in a given issue, and there must be some degree of coordination between them. A vanguard state is able to set the agenda of ASEAN and to portray a united ASEAN front in support of vanguard state interests. The dependent variable of this study is success of ASEAN vanguard state resistance to sovereignty violation. ASEAN success, or lack thereof, at resistance to such deviations will be assessed using case study analysis. Sovereignty is understood in terms of the Westphalian model, defined as an 'institutional arrangement for organizing political life that is based on two principles: territoriality and the exclusion of external actors from domestic authority structures'. ${ }^{62}$ Both the independent variable and dependent variable are to be viewed as continuous variables, characterized by a sliding scale of convergence or success. This dynamic can be restated in the following hypothesis: if there is an increase in interest convergence between an ASEAN vanguard state and an external actor, then this will cause an increase in success of resistance to sovereignty violation; conversely, if there is a decrease in interest convergence between an ASEAN vanguard state and an external actor, then this will cause a decrease in success of resistance to sovereignty violation.

\section{Defining and measuring interest convergence}

In advancing an alternative account in the literature, the critical independent variable in our analysis is the degree of convergence in state interests between an ASEAN vanguard state and a specific external actor or actors. Consistent with a realist theoretical approach, we draw on a realist understanding of how interests are defined. This can be contrasted with a constructivist conception, whereby 'interests are constructed through social interaction ... [and] are defined in the context of internationally held norms and understandings about what is good and appropriate'. ${ }^{63}$ Following the work of Stephen Krasner, analysis begins with, and ultimately attempts to defend, the basic premise underlying what has become known as the state-centric realist paradigm. In this view, states (defined as central decision-making institutions and roles) can be treated as unified, rational actors pursuing aims understood in terms of the national interest. ${ }^{64}$

Interests enjoy a strong tradition within the realist literature, where there exists a consistent view of the basic state interest, which is state survival. For example, classical realist Hans Morgenthau argues that 'the state has no right to let its moral disapprobation of the infringement 
of liberty get in the way of successful political action, itself inspired by the moral principle of national survival'. ${ }^{65}$ Similarly, neorealist Kenneth Waltz believes that 'by comparing nations and corporations, the elusive notion of national interest is made clear. By assumption, economic actors seek to maximize expected returns, and states strive to secure their survival'. ${ }^{66}$ John Mearsheimer reaffirms this view, stating that 'survival is the primary goal of great powers' ${ }^{67}$ When a state must act to ensure its survival, this constrains a state's consideration of broader interests. However, during periods of relative peace, 'powers have the "luxury" of choosing their interests and goals" ${ }^{68}$ During such times, a range of other values will be sought, including 'rank, respect, material possessions and material privileges'. ${ }^{69}$

An understanding of the foregoing literature leads us to conceptualize our variables in a particular way. For the purposes of analysis, this study begins with the basic assumption that state interests are premised on the basic point of seeking survival. Building on the works of Timothy Crawford ${ }^{70}$ and Daryl Press, ${ }^{71}$ a continuous variable has been constructed representing the state interests at stake, with vital interests at one end and secondary interests at the other. Crawford defines vital interests as involving 'self-preservation, political independence, and, by extension, defence of strategically vital areas'. ${ }^{72}$ Similarly, Press defines vital interests as preservation of 'sovereignty'. ${ }^{73}$ Secondary interests can vary greatly, and may range 'from very important interests, such as maintaining trade routes, the safety of your allies, and even national "prestige", to much more ephemeral ones' ${ }^{74}$ While ranking the hierarchy of state interests is inherently difficult, ultimately interests pertaining to national self-preservation logically must take precedence. ${ }^{75}$ A theory of vanguard state interests therefore begins with the basic assumption that states seek to secure their survival, but acknowledges that states have many interests, which they will seek to pursue when survival is not at stake. This is especially applicable in the case of weak states. According to Handel, 'the international system leaves [weak states] less room for choice in the decision-making process. Their smaller margin of error and hence greater preoccupation with survival makes the essential interests of weak states less ambiguous' ${ }^{76}$

Cooperation may be based on a response to threats, ${ }^{77}$ or for the pursuit of gains. ${ }^{78}$ Convergence is measured by identifying symmetric or asymmetric interests, ${ }^{79}$ whether vital or secondary (as defined by Crawford), and arrangements for cooperation between states. This study acknowledges that complete interest convergence between states is difficult to obtain. Varying degrees of interest convergence are possible, and interests can change over time. Partial interest 
convergence between an ASEAN state and an external actor is unlikely to elicit the high levels of sustained cooperation required to cause ASEAN state resistance to sovereignty violation. A high level of interest convergence is required to elicit the cooperation required to resist violations to state sovereignty. Interest convergence is a dynamic process, whereby small states actively seek 'maximum great-power commitment to their security interests while trying to minimize the price of obtaining that support'. ${ }^{80}$ They do so because they 'generally lack formidable independent power capabilities' and as such 'cannot affect the international security landscape on their own'. ${ }^{81}$ However, because some small states 'occupy strategic positions', they can 'affect the overall global distribution of power by adding to the resources of some great powers and constraining others' ${ }^{82}$

Engaging with this literature, our analysis begins with the underlying premise that the study of interest convergence can yield utility to the field of Southeast Asian international relations. As this study will show, without external actor interest convergence, ASEAN is unable to resist sovereignty violations from powers external to the region. During periods of decreased interest convergence, this analysis shares the same expectations as Leifer and Jones and Smith, and is consistent with existing realist literature. However, this study contributes to the literature by demonstrating that when a clear interest convergence occurs between an ASEAN state and an external power, a substantial compact is constructed. In short, an ASEAN vanguard state plays the important and necessary function of actively seeking and supporting a great power commitment to regional policies, or intervention in regional affairs, which are consistent with the interests of both the ASEAN state and the external actor. At this time, an ASEAN vanguard state has an active and substantial role in resisting sovereignty violations from other external powers. Great powers will use regional institutions to pursue their own interests. ${ }^{83}$ When vital interests are at stake, however, regional states will seek to do the same.

\section{Vanguard state theory: on balancing, bargaining and power}

The aim of this research is to provide a better understanding of ASEAN institutional dynamics and patterns of state behaviour. It does so by constructing a theory of foreign policy, defined as a theory that can 'explain why different states or even the same state at different times pursues particular strategies in the international arena' ${ }^{84}$ Its core 
assumptions are realist in nature, based upon a state-centric view of the international system, where states exist in a decentralized and anarchic system characterized by the principle of self-help. ${ }^{85}$ Its primary focus is on state interests and the role of a 'vanguard state', conceptualized as an ASEAN state that comes to the fore of the Association when it has vital interests at stake that it wishes to pursue. As defined by Crawford ${ }^{86}$ and Press, ${ }^{87}$ these vital interests relate to state survival and the preservation of state sovereignty. Vanguard state behaviour is variably understood as either security maximizing, ${ }^{88}$ or power maximizing. ${ }^{89}$ An ASEAN state only begins to assume the role of vanguard state when vital interests are at stake, when state security is threatened and very possibly under conditions of actual conflict.

Once a vanguard state has come to prominence, it will perform two major functions, which reflect an external balancing logic. ${ }^{90}$ First, because of its relative weakness, the vanguard state will actively seek out an external power whose interests align with its own. Second, the vanguard state will seek to portray a united ASEAN front in support of its interests, by engaging and mobilizing states within the institution. This supports the view that states will engage in balancing behaviour, and that 'balances of power [will] recurrently form'. ${ }^{91}$ There are a number of different strategies at a vanguard state's disposal to engage an external power and a regional state. The most important of these are through intelligence gathering, opening channels of communication and engaging in high-level meetings, much of which is predicated on the basis of prior relationships, perceived credibility and reputation. ${ }^{92}$ It is through these methods that a vanguard state will identify convergent state interests. A vanguard state may use diplomacy, bargaining, incentives, coercion and bilateral agreements or alliances to further solidify this interest convergence.

Two dominant factors shaping ASEAN dynamics and behavioural patterns are individual state threat perceptions ${ }^{93}$ and relative power visà-vis other members of the international system. It is this consideration of relative power that dictates ASEAN state relations externally, with respect to great powers, and internally, with respect to the regional organization itself. When assessing its ability to effect change, a regional state recognizes that its limited material capabilities require it to pursue enhanced relations with a great power. Of equal importance for our theory is the relative power dynamic within ASEAN. For a vanguard state to influence other ASEAN members, it must have the relative power to do so. This supports the view that 'estimates of relative power are the currency of diplomatic bargaining'. ${ }^{94}$ It is therefore not surprising that, of the case studies presented here, Indonesia as the 
region's dominant power has had most success in its role of vanguard state, and Vietnam and the Philippines the least. Intra-ASEAN power dynamics do matter, as our analysis will seek to show.

For the purpose of this study, sovereignty, autonomy and intervention are conceptualized in terms of power. Autonomy is considered a core principle of state sovereignty. According to Krasner, the principle of autonomy is one of the core elements of Westphalian sovereignty, and means that "no external actor enjoys authority within the borders of the state'. ${ }^{95}$ Michael Mann intrinsically links the concepts of autonomy and sovereignty to power. Mann argues that a state's ability to 'provide a territorially-centralized form of organization' provides for state autonomy. ${ }^{96}$ For Mann, it is this institutional and territorial centralized nature that is 'the most important precondition of state power' ${ }^{97}$ Hence, power is an essential element in the relationship between sovereignty and autonomy.

According to the Westphalian model, sovereignty can be violated through imposition, where a weak state is forced to do something it would not ordinarily do, and intervention, where more powerful states coerce 'public authorities in weaker states to accept externally dictated authority structures' ${ }^{98}$ For many, the principle of non-intervention, which is always violated through coercion or imposition, is the key element of sovereign statehood..$^{99}$ Interventions occur when there is an asymmetry of power. ${ }^{100}$ Because powerful states intervene in the internal affairs of less powerful states, ${ }^{101}$ weaker states have always been the 'strongest supporters' of the rule of non-intervention. ${ }^{102}$ Weaker states will always seek to resist violations to their sovereignty. It is our contention that they are able to do so when their interests converge with that of an external actor.

\section{Conceptualizing ASEAN}

The way in which ASEAN is conceptualized, and the degree to which ASEAN can be considered an 'actor', is debated here. Defined by Rüland as the ability to 'develop presence, to become identifiable, aggregate interests, formulate goals and policies, make and implement decisions', ${ }^{103}$ a key ability for any actor is to 'formulate a coherent position', and to receive recognition and identification as an actor in a given context. ${ }^{104}$ As case study analysis of the South China Sea dispute will show, ASEAN lacks the ability to consistently aggregate interests and formulate coherent policy, in part due to its loose institutional organization and preference for consensus decision-making. This 
places limits on the degree of ASEAN's 'actorness'. However, our analysis suggests that at times of vanguard state prominence, once a vanguard state has successfully mobilized the member states in support of its interests, ASEAN can be conceptualized as a unitary actor. This is in accordance with the work of Frey, who argues that any group actors 'must display sufficient behavioural cohesion among members so as to produce unitary group actor behaviour' ${ }^{105}$ While the degree of cohesion required to elicit unitary group actor behaviour must be high, Frey acknowledges that 'absolutely unitary action is a naively impractical criterion for a group actor'. ${ }^{106}$ As such, evidence of minor or insignificant state deviations from cohesion should not result in denial of group actor designation.

As our analysis will show, these moments of cohesion are both rare, and can be victim to power dynamics within the grouping. In the periods when ASEAN cannot be considered a unitary actor, which, as evidence will show, is the overwhelming majority, ASEAN is understood as a grouping of member states. ASEAN resistance to sovereignty violation therefore refers to member state ability to resist sovereignty transgressions. Clearly, this ability has repercussions for the whole Southeast Asian region, where 'Southeast Asia' is defined as the geographical area encompassed by the ten member states of ASEAN.

\section{Methodology}

This book adopts a case-study analysis of the concept of ASEAN resistance to sovereignty violation. Cases have been selected in order to demonstrate variation on the dependent variable. Specifically, cases selected show a range of variation characterized by different levels of success. By showing variation on the dependent variable, the study seeks to avoid the very serious problem of selection bias, which occurs when we 'subtly or not so subtly select observations on the basis of combinations of the independent and dependent variables that support the desired conclusion'. ${ }^{107}$ To avoid selection bias, 'selection should allow for the possibility of at least some variation on the dependent variable'. ${ }^{108}$ Thus, to illustrate this I have chosen four case studies, which span five decades since ASEAN's establishment. The four cases that this study will examine are: the Indonesian invasion of East Timor (1975); the Third Indochina War (1978-91); the East Timor humanitarian crisis (1999); and The South China Sea Dispute (1992 to present). 
The Indonesian invasion of East Timor (1975) and the East Timor humanitarian crisis (1999) deal with the same key actors. A significant factor in favour of the selection is that the cases represent variation on the dependent variable. The 1975 case is an example of successful resistance to sovereignty violation, and the 1999 case an example of failure to resist sovereignty violation. As such, they offer an explanation for varying outcomes, in addition to providing evidence for changing state interests over time. Similarly, the South China Sea Dispute (1992 to present) shows variation in interest convergence over a 25-year time frame, and represents a good case to test partial convergence. The Third Indochina War (1978-91) is prevalent in the constructivist, critical theory and realist literature. As such, it acts as a good case to test existing theoretical explanations, in addition to the vanguard state theory posited in this book. An additional and compelling rationale for the case selection relates to the availability of empirical evidence. Declassified US state documents for the period up to 1980 provide a strong empirical basis for the Indonesian invasion of East Timor (1975) and the Third Indochina War (1978-91). The availability of media reports and United Nations documentation also provide a strong empirical foundation for the East Timor humanitarian crisis (1999) and the South China Sea Dispute (1992 to present).

According to the work of Arthur Stinchcombe, ${ }^{109}$ we must observe covariation in order to derive observations in support of causal theory. Without variation in the causal variable, it is not possible to observe variations in the dependent variable. To establish covariation, my independent variable is a continuous variable characterized by variation in interest convergence. Change of this variable should change the value of the dependent variable, thus establishing causal direction. In an attempt to make causal inferences, this study will employ a processtracing technique. The benefits of case study analysis are discussed in depth by Van Evera. Of particular note is Van Evera's discussion of the benefits of tests using a process-tracing methodology, which 'gain strong controls from the uniform character of the background conditions of the case'. ${ }^{110}$ This allows for a number of observations of values on the independent and dependent variable. Through process tracing it is possible to 'examine the process whereby initial case conditions are translated into case outcomes' ${ }^{111}$

This book seeks an answer to the following question: when has ASEAN state resistance to sovereignty challenges succeeded, and when has it failed? ASEAN resistance to sovereignty challenge is understood in terms of the Association's ability to exclude external actors from the domestic authority structures of any ASEAN state. ${ }^{112}$ 
All four cases represent examples of ASEAN resistance to sovereignty challenges aimed at an ASEAN vanguard state. The Indonesian invasion of East Timor (1975) is an example of Indonesia successfully resisting challenges to its sovereignty from the United Nations and the international community. These external actors increasingly sought to intervene in Indonesia's domestic affairs following the invasion. Interest convergence with key external powers ultimately prevented this from occurring. The Third Indochina War (1978-91) is an example of Thailand successfully resisting territorial sovereignty violation from an aggressive neighbouring state, Vietnam, which was backed by the Soviet Union, a pole in the international system. The East Timor humanitarian crisis (1999) is an example of Indonesia failing to resist challenges to its sovereignty, after an international peacekeeping force entered East Timor. The South China Sea dispute (1992 to present) is an example of the Philippines and Vietnam partial interest convergence with the United States, and the inability of these states to resist violation of their sovereignty from an assertive China in the South China Sea.

The question of ASEAN's ability to resist sovereignty challenges is critical to the field of international relations for two important reasons. First, it illuminates the dynamic of the ASEAN states' sovereignty practices. ${ }^{113}$ The principle of sovereignty provides a state with authority and control over its people and territory, in addition to securing against intervention by external actors. ${ }^{114}$ ASEAN's ability to uphold this in practice has clear implications for state autonomy and security, and is of importance to the individual states, the organization and the region as a whole. Indeed, this has wider implications for any small states and regional organizations within the international system. Second, it clarifies the contested question of the ability of ASEAN to uphold its norms and principles, specifically the principle of non-intervention by external powers, ${ }^{115}$ and the norm of upholding regional autonomy. ${ }^{116}$ ASEAN's ability, or lack thereof, to uphold these principles is of vital importance to regional security, and to the security of the wider international community.

\section{Notes}

1 Contents from this chapter originally published in Journal of Asian Security and International Affairs, Vol. 2 No. 2 and Journal of Asian Security and International Affairs, Vol. 3 No. 2. Copyright 2015/2016 (C) SAGE Publications India Private Limited, New Delhi. All rights reserved. Reproduced with the permission of the copyright holders and the publishers, SAGE Publications India Pvt. Ltd, New Delhi. 
2 Acharya, Constructing a Security Community in Southeast Asia, 25-28.

3 Nicholas Khoo, "Deconstructing the ASEAN Security Community: A Review Essay," International Relations of the Asia-Pacific 4, no. 1 (2004), 39.

4 Alice Ba, "Institutional divergence and convergence in the Asia-Pacific? ASEAN in practice and theory," Cambridge Review of International Affairs 27, no. 2 (2014), 296.

5 Aarie Glas, "Habits of peace: Long-term regional cooperation in Southeast Asia,” European Journal of International Relations 23, no. 4 (2017), 834.

6 Glas, "Habits of peace," 838.

7 Glas, "Habits of peace," 842.

8 Randall Schweller and David Priess, "A Tale of Two Realisms: Expanding the Institutions Debate," Mershon International Studies Review 41, no. 1 (May 1997), 8.

9 Edward D Mansfield, "International Institutions and Economic Sanctions," World Politics 47, no. 44 (1995), 600.

10 Lloyd Gruber, Ruling the World: Power Politics and the Rise of Supranational Institutions (Princeton: Princeton University Press, 2000), 18.

11 Terry M Moe, "Power and Political Institutions," Perspectives on Politics 3, no. 2 (2005), 229.

12 Acharya, Constructing a Security Community, 25.

13 Acharya, Constructing a Security Community, 4.

14 Acharya, Whose Ideas Matter? 20-22.

15 Haacke, ASEAN'S Diplomatic and Security Culture, 1.

$16 \mathrm{Ba},[$ Re]Negotiating East and Southeast Asia, 122.

17 John Mearsheimer, "The False Promise of International Institutions," International Security 19, no. 3 (Winter 1994/1995), 42.

18 Mearsheimer, "The False Promise of International Institutions," 43.

19 Kenneth Waltz, Theory of International Politics (New York: McGraw Hill, 1979), 74.

20 Cameron Thies, "State Socialization and Structural Realism," Security Studies 19, no. 4 (2010), 715.

21 Alexander Betts and Phil Orchard, "Introduction: The Normative Institutionalization-Implementation Gap," in Implementation and World Politics ed. Alexander Betts and Phil Orchard (Oxford: Oxford University Press, 2014), 1.

22 Betts and Orchard, "Introduction," 1-2.

23 Alexander Betts and Phil Orchard, "Conclusions: Norms and the Politics of Implementation," in Implementation and World Politics, 272.

24 Betts and Orchard, "Introduction," 12.

25 Betts and Orchard, "Introduction," 17.

26 Betts and Orchard, "Introduction," 16. 
27 Alexander Betts, "From Persecution to Deprivation: How Refugee Norms Adapt at Implementation," in Implementation and World Politics, 29-49.

28 Brian L Job and Anastasia Shesterinina, "China as a Global Norm-Shaper: Institutionalization and Implementation of the Responsibility to Protect," in Implementation \& World Politics, 144-159.

29 Urvashi Aneja, "Interanational NGOs and the Implementation of the Norm for Need-Based Humanitarian Assistance in Sri Lanka," in Implementation and World Politics, 85-104.

30 Chin and Suryadinata, Michael Leifer: Selected Works, 146. Reprinted in abridged form from Michael Leifer, "Regional Solutions to Regional Problems?" in Towards Recovery in Pacific Asia, ed. Gerald Segal and David SG Goodman (London: Routledge, 2000), 108-18.

31 Chin and Suryadinata, Michael Leifer: Selected Works, 151.

32 Chin and Suryadinata, Michael Leifer: Selected Works, 151.

33 Jones and Smith, “ASEAN's Imitation Community," 102.

34 Jones and Smith, "Making Process, Not Progress," 150.

35 Jones and Smith, "Constructing Communities," 175-176.

36 Jones and Smith, ASEAN and East Asian International Relations, 52.

37 Jussi Hanhimäki, The Flawed Architect: Henry Kissinger and American Foreign Policy (Oxford: Oxford University Press, 2004), 478.

38 As evidenced by the Association of Southeast Nations, "Joint Communiqué of the Ninth ASEAN Ministerial Meeting," Manila, 24-26 June 1976, Article 23.

39 Jones and Smith, ASEAN and East Asian International Relations, 55.

40 Leifer, ASEAN and the Security of South-East Asia, 98.

41 Michael Chambers, "'The Chinese and the Thai are Brothers': The Evolution of the Sino-Thai Friendship,' Journal of Contemporary China 14, no. 45 (2005), 599-629.

42 Jones, ASEAN, Sovereignty and Intervention in Southeast Asia, 2.

43 Jones, ASEAN, Sovereignty and Intervention in Southeast Asia, 8.

44 Jones, ASEAN, Sovereignty and Intervention in Southeast Asia, 11.

45 Jones, ASEAN, Sovereignty and Intervention in Southeast Asia, 24.

46 Kelly Gerard, "Crises, Civil Society and Regionalism in Southeast Asia," in Crisis and Institutional Change in Regional Integration, ed. Sabine Saurugger and Fabien Terpan (London: Routledge, 2016), 193.

47 John Mearsheimer, "Structural Realism," in International Relations Theories: Discipline and Diversity 3rd ed, ed. Tim Dunne, Milja Kurki and Steve Smith (Oxford: Oxford University Press, 2013), 78.

48 Gideon Rose, "Neoclassical Realism and Theories of Foreign Policy," World Politics 51, no. 1 (1998), 144-172. 
49 Brian Rathbun, "A Rose by Any Other Name: Neoclassical Realism as the Logical and Necessary Extension of Structural Realism," Security Studies 17, no. 2 (2008), 312.

50 Rathbun, "A Rose by Any Other Name," 317.

51 Jones, ASEAN, Sovereignty and Intervention in Southeast Asia, 17.

52 Jones, ASEAN, Sovereignty and Intervention in Southeast Asia, 24.

53 Jones, ASEAN, Sovereignty and Intervention in Southeast Asia, 18.

54 Jones, ASEAN, Sovereignty and Intervention in Southeast Asia, 19.

55 Joseph Grieco, "State Interests and Institutional Rule Trajectories: A Neorealist Interpretation of the Maastricht Treaty and European Economic and Monetary Union," Security Studies 5, no. 3 (March 1996), 261-306.

56 Gil Merom, "Realist Hypotheses on Regional Peace," Journal of Strategic Studies 26, no. 1 (2003), 109-135.

57 Grieco, "State Interests and Institutional Rule Trajectories," 264, 286-90.

58 Merom, "Realist Hypotheses on Regional Peace," 109.

59 Merom, "Realist Hypotheses on Regional Peace,"121-25.

60 Colin Elman, "Horses for Courses: Why Not Neorealist Theories of Foreign Policy?" Security Studies 6, no. 1 (1996): 7-53.

61 Waltz, Theory of International Politics, 79-102.

62 Krasner, Sovereignty: Organized Hypocrisy, 20.

63 Martha Finnemore, National Interests in International Society (Ithaca, NY: Cornell University Press, 1996), 2.

64 Stephen Krasner, Defending the National Interest: Raw Materials Investments and US Foreign Policy (Princeton, NJ: Princeton University Press, 1978), 12.

65 Hans Morgenthau, Politics Among Nations, 4th ed. (New York: Alfred Knopf, 1967), 10.

66 Waltz, Theory of International Politics, 134.

67 John Mearsheimer, The Tragedy of Great Power Politics (New York: WW. Norton \& Co., 2001), 31.

68 Fareed Zakaria, From Wealth to Power: The Unusual Origins of America's World Role (Princeton, NJ: Princeton University Press, 1998), 186.

69 Arnold Wolfers, "National Security as an Ambiguous Symbol," Political Science Quarterly 67, no. 4 (1952): 489.

70 Timothy Crawford, Pivotal Deterrence: Third-Party Statecraft and the Pursuit of Peace (Ithaca, NY: Cornell University Press, 2003), 30-31.

71 Daryl G Press, Calculating Credibility: How Leaders Assess Military Threats (Ithaca, NY: Cornell University Press, 2005), 25-28.

72 Crawford, Pivotal Deterrence, 31.

73 Press, Calculating Credibility, 26.

74 Crawford, Pivotal Deterrence, 31.

75 Crawford, Pivotal Deterrence, 31. 
76 Michael Handel, Weak States in the International System (London: Frank Cass and Company, 1981), 3.

77 Stephen Walt, The Origins of Alliances (London: Cornell University Press, 1987).

78 Joseph Grieco, "Realist Theory and the Problem of International Cooperation: Analysis with an Amended Prisoner's Dilemma Model," The Journal of Politics 50, no. 3 (1988): 600-624.

79 Robert S. Ross, "Navigating the Taiwan Strait: Deterrence, Escalation, Dominance, and U.S.-China Relations," International Security 27, no. 2 (2002): 48-85.

80 John D. Ciorciari, The Limits of Alignment: Southeast Asia and the Great Powers since 1975 (Washington, DC: Georgetown University Press, 2010), 2.

81 Ciorciari, The Limits of Alignment, 1.

82 Ciorciari, The Limits of Alignment, 1.

83 Schweller and Priess, "A Tale of Two Realisms," 12.

84 Jeffrey Taliaferro, Balancing Risks: Great Power Intervention in the Periphery (Ithaca, NY: Cornell University Press, 2004), 2.

85 Waltz, Theory of International Politics, 79-102.

86 Crawford, Pivotal Deterrence, 31.

87 Press, Calculating Credibility, 26.

88 See Waltz, Theory of International Politics, 134.

89 See Mearsheimer, The Tragedy of Great Power Politics, 33.

90 Waltz, Theory of International Politics, 168.

91 Waltz, Theory of International Politics, 128.

92 Thomas Schelling, "An Essay on bargaining," The American Economic Review 46, no. 3 (1956), 281-306.

93 Walt, Origins of Alliances.

94 Randall Schweller and William Wohlforth, "Power test: Evaluating realism in response to the end of the Cold War," Security Studies 9, no. 3 (2000), 71.

95 Stephen Krasner, "Rethinking the Sovereign State Model," Review of International Studies 27, no. 5 (December 2001), 18.

96 Michael Mann, "The Autonomous Power of the State: its Origins, Mechanisms and Results," European Journal of Sociology 25, no. 2 (November 1984), 185.

97 Mann, "The Autonomous Power of the State," 198.

98 Krasner, Sovereignty: Organized Hypocrisy, 8.

99 Krasner, Sovereignty: Organized Hypocrisy, 20.

100 Stephen Krasner, "Sovereignty and Intervention," in Beyond Westphalia? 229.

${ }^{101}$ Krasner, "Sovereignty and Intervention," 229.

102 Krasner, Sovereignty: Organized Hypocrisy, 21. 
103 Jürgen Rüland, "Inter- and Transregionalism; Remarks on the State of the Art of a New Research Agenda." National Europe Centre Paper (35), Paper prepared for the workshop on Asia-Pacific Studies in Australia and Europe: A Research Agenda for the Future, ANU, July 5-6 (2002), 6.

${ }^{104}$ Frank Mattheis and Uwe Wunderlich, "Regional actorness and interregional relations: ASEAN, the EU and Mercosur," Journal of European Integration 39, no. 6 (2017), 725.

105 Frederick Frey, "The Problem of Actor Designation in Political Analysis," Comparative Politics 17, no. 2 (January 1985), 144.

106 Frey, "The Problem of Actor Designation in Political Analysis," 144.

107 Gary King, Robert O Keohane and Sidney Verba, Designing Social Inquiry: Scientific Inference in Qualitative Research (Princeton, NJ: Princeton University Press, 1994), 128-129.

108 King, Keohane, Verba, Designing Social Inquiry, 128-129.

109 See Arthur Stinchcombe, Constructing Social Theories (New York: Harcourt, Brace \& World Inc., 1968), 32-38.

110 See Stephen Van Evera, Guide to Methods for Students of Political Science (London: Cornell University Press, 1997), 50-55.

111 Van Evera, Guide to Methods for Students of Political Science, 50-55.

112 Krasner, Sovereignty: Organized Hypocrisy, 20.

113 Krasner, Sovereignty: Organized Hypocrisy, 5.

114 David A Lake, Hierarchy in International Relations (New York: Cornell University Press, 2009), 46-47.

115 ASEAN, Treaty of Amity and Cooperation in Southeast Asia, Article 2b.

116 Acharya, Constructing a Security Community, 80; Jones and Smith, "Making Process, Not Progress," 150; Jones, ASEAN, Sovereignty and Intervention in Southeast Asia, 2. 


\section{The Indonesian Invasion of East Timor}

On 12 December 1975, the United Nations General Assembly (UNGA) introduced Resolution 3485, 'strongly deplor[ing] the military intervention of the armed forces of Indonesia in Portuguese Timor'. ${ }^{1}$ This was followed by two diluted UN Security Council (UNSC) resolutions introduced on 22 December 1975 and 22 April 1976, 'call[ing] upon the Government of Indonesia to withdraw without delay all its forces from the Territory'. ${ }^{2}$ Resolution 3485 passed with 72 votes to 10 , and 43 abstentions. ${ }^{3}$ Abstentions came from Europe, New Zealand and the US. The United Nations (UN) votes were indicative of the way Indonesian officials 'correctly judged the balance of forces' when planning their invasion of the former colony. ${ }^{4}$ They faced relatively little international condemnation, either at the time of invasion, during its aftermath, or indeed, for the majority of its 27-year occupation. In the view of both London and Washington during the 1970s and 1980s, East Timor was deemed 'too small, backwards and isolated to survive on its own'. ${ }^{5}$

During Indonesia's invasion of East Timor in 1975, Indonesia was able to act with relative impunity. Despite UN Resolution 3485, Jakarta was supported in its actions by the member states of ASEAN, the US and Australia. Indeed, it can be argued that without external support, it is unlikely Indonesia would have invaded East Timor at that time. With regional and external power backing, Indonesia was able to resist international opposition in East Timor following the invasion, thus resisting any potential violation of its sovereignty at that time. In the case under investigation, Indonesia can be classified as the ASEAN vanguard state, having the most compelling interests at stake with regards to East Timor. From Jakarta's perspective, decolonization of the territory represented a power vacuum, which could invite 
unwanted attention from powers external to the region. It was also an opportunity for Indonesia to enhance its security, and maximize power regionally, by absorbing the territory within the archipelago. As the vanguard state, Indonesia was able to garner great power security commitments, and apply pressure on the ASEAN states to obtain unanimous support for Indonesia's East Timor policy in 1975.

While Indonesia had an important role to play in this process, an equally important factor is the role played by external actors. In 1975, ASEAN's ability to resist violations to the sovereignty of Indonesia from a UN-backed international coalition was a consequence of high interest convergence between Indonesia and the external powers, specifically the US and Australia. For the US, Indonesia was a key regional ally following defeat in Vietnam and retrenchment from the region. For Australia, Indonesia was a vital component in securing Australia's Northern periphery, and allowing entry into regional organizations. In the context of a Cold War regional environment, there were clear interests for these external powers to support Indonesia. Ultimately, this would take precedence over self-determination for the people of East Timor.

The chapter will begin by describing the regional environment between 1970 and 1975, paying specific attention to Indonesia's role in this environment. It will then consider the factors surrounding decolonization in East Timor and the subsequent civil war that occurred there. It will assess Indonesia's interests regarding the territory, and how this led to the emergence of the ASEAN vanguard state. Subsequent analysis will consider the interests of both the United States and Australia in 1975, and how these interests converged with Indonesia's with regard to East Timor, in addition to Indonesia's role within ASEAN and the level of cohesion that developed in support of Indonesia's East Timor policy. Following an assessment of the empirical record surrounding Indonesia's invasion of East Timor in 1975, the chapter will detail the ways in which regional and external power interest convergence helped Indonesia to resist potential sovereignty violation from actors external to the region. The chapter will conclude with a theoretical assessment of the case study, and consider contending theoretical explanations for Indonesia's ability to resist sovereignty violation following the invasion of East Timor in 1975. 


\section{Indonesia and the Cold War regional environment (1970-1975)}

Why did Indonesia invade and annex East Timor? As one commentator noted, 'the international geopolitical context ... [created] favourable conditions for the invasion'. Therefore, a consideration of the regional environment is critical, and reflects the strong role played by Indonesian interests during that period. The year 1975 saw a number of communist advances in Indochina. On 17 April 1975, the communist Khmer Rouge came to power in Cambodia. In Vietnam, the North Vietnamese communists had overrun Saigon. By April 1975, the Pathet Lao took power in Laos, transforming the country into the Lao Popular Democratic Republic. Communist success in Vietnam was met with alarm in Southeast Asia, although the degree of alarm differed according to each state's geographic location and external security guarantees. ${ }^{7}$

Indonesia's size, location and anti-communist leanings meant that it had a unique role to play in Southeast Asia's Cold War environment. Indonesia's President Suharto gradually assumed power in Indonesia following a military backed coup in October $1965 .{ }^{8}$ In the period following the coup, Suharto's forces 'organized and encouraged the killing of as many as one million real or alleged members of the PKI [Communist Party of Indonesia]'. ${ }^{9}$ Following the deposition of Sukarno, Indonesia's sitting President at the time of the coup, Suharto established a new regime in Indonesia known as the New Order, which immediately received US and other Western state backing. In doing so, Western powers were able to help eradicate communist elements in Indonesia. The New Order was characterized by the dominance of a number of elite combat units, known as the Kopassus. Seeking to exert domestic control, Suharto's regime focused on the danger posed by the resurrection of communist elements, which it believed could threaten both national and regional stability. ${ }^{10}$ By 1975 , Indonesia suddenly found itself in 'the limelight as the largest power in the region'. ${ }^{11}$ In this context, Suharto 'appeared to be the greatest barrier to Communist advances in the region, and was thus an essential factor in the defense of Western interests'. ${ }^{12}$ 


\section{Decolonization in East Timor: emergence of the ASEAN vanguard state}

Within this Cold War regional setting, the small territory of East Timor gained its independence from Portuguese colonial rule in April 1975. East Timor is the largest island of the Sunda island chain, with Western Timor forming part of the Indonesian archipelago. Its capital Dili is located 600 kilometres from Darwin, the closest Australian airport, and approximately 2,000 kilometres from Jakarta. ${ }^{13}$ In 1975, the population of East Timor was approximately 652,250 to $707,500 .{ }^{14}$ Following Portuguese colonial rule, a number of different indigenous factions began to emerge. The first faction was the Timorese Popular Democratic Association (Apodeti). Encouraged by Jakarta, Apodeti advocated integration with Indonesia. The second faction was the Timorese Democratic Union (UDT), which advocated gradual decolonization and continued links with Portugal. The final faction was the Revolutionary Front for an Independent East Timor (FRETILIN), which supported an independent East Timor with immediate effect. In addition to these three main parties, two smaller parties also emerged: the Klibur Oan Timur Aswain (KOTA), the Sons of the Mountain Warriors, and Trabalhista, a Labour Party. By mid-1975, FRETILIN had emerged as the dominant faction.

Indonesia's General Suharto denied any aspirations to incorporate the former Portuguese colony into the Indonesian archipelago, instead arguing that the Timorese had the right to self-determination. At the same time, 'political elites in Jakarta periodically suggested that East Timor's future lay with Indonesia'. ${ }^{15}$ This suggestion was acknowledged by many Western elites, who 'resigned themselves as a matter of policy to [East Timor's] eventual absorption by Indonesia'. ${ }^{16}$ Indonesia's subversive actions in Timor prior to Portuguese decolonization undoubtedly fuelled these speculations. In April 1972, Indonesia's Foreign Minister Adam Malik 'stated that Indonesia would support an anti-Portuguese liberation movement if the Timorese people really wanted it'. ${ }^{17}$ By mid-1974, 'unidentified Indonesian sources in Kupang began giving financial aid and radio broadcast assistance to Apodeti, apparently in the expectation that the organization would win popular support for a voluntary merger of East Timor with Indonesia'. ${ }^{18}$ By December 1974, '100 Indonesian commandos were sent to West Timor as part of the first phase of a campaign to destabilize East Timor'. ${ }^{19}$ According to Leifer, 'Indonesia cloaked an evident interest in studied ambivalence ... [which] persisted in declaratory policy even after overt military intervention had virtually decided the political 
future of East Timor'. ${ }^{20}$ While reasons for Indonesia's interest in East Timor have never been explicitly stated, evidence suggests two important factors at play. Both of these factors provided Indonesia with the most compelling interests at stake in the future of East Timor.

\section{Security and the communist threat}

First, there were basic security concerns. The territory of East Timor represented a power vacuum, geographically proximate to Indonesia's border. Jakarta feared that this might invite increased communist diplomatic attention and influence in Southeast Asia. In a recorded meeting between Suharto and the Australian Prime Minister Gough Whitlam in September 1974, Suharto argued that 'if Portuguese Timor were to become independent, it would give rise to problems. It [is] not economically viable. It would have to seek the help of another country ... there [is] a big danger that communist countries - China or the Soviet Union - might gain the opportunity to intervene'. ${ }^{21}$ Suharto's claims are significant in that they reflect Indonesian regional-based fears that directly stem from the Cold War environment. Indonesia's decision to become involved in East Timor occurred, 'not because the Portuguese half of the island was perceived as an asset but because it was thought necessary to secure it in order to deny its uncertain utility to others'. ${ }^{22}$ Indonesia's support for Apodeti can therefore be viewed in light of Indonesia's concern with national security. This was especially necessary considering Jakarta's 'fundamental sense of territorial vulnerability, arising from geographic fragmentation and ethno-religious diversity, made acute by the dominant influence of the military and their perspective in government'. ${ }^{23}$ In Jakarta's view, East Timor represented a potential 'backdoor entrance' for the spread of insurgency movements. The prospect of a FRETILIN controlled East Timor 'was not taken lightly in Jakarta, particularly among the military, where great concern was expressed over the likelihood that a Marxist-led eastern Timor could become a support base for communist insurgencies and infiltration throughout Indonesia'. ${ }^{24}$ Even an East Timor controlled by the UDT was of little comfort. This was because the new Portuguese government 'was seen as unstable and vulnerable to communist takeover' ${ }^{25}$ As Suharto informed Whitlam in 1974, 'decolonization in Portuguese Timor should not upset either Indonesian or regional security'. ${ }^{26}$

It is undeniable that following Vietnamese communist victory in Indochina, there existed a generalized fear of communist expansion 
in Southeast Asia, so security-based concerns were a reality. Arguably, however, Suharto's comments on East Timor were also an attempt to justify a power-maximizing Indonesian policy. This assessment is supported by the fact that, while states have to consider future expectations in formulating policy, ${ }^{27}$ there is little evidence of actual communist intent to intervene in East Timor. Indeed, Indonesia appears to have exaggerated the communist threat by 'fabricat[ing] press reports [claiming] Chinese agents were orchestrating antiIndonesian and pro-independence sentiment in East Timor and that Beijing was providing FRETILIN with arms and military preparation for a communist coup' ${ }^{28}$ In an Australian government letter sent from Minister John McCredie to First Assistant Secretary of South East Asia Division Graham Feakes in May 1974, McCredie stated that 'there is as yet no evidence that we are aware of regarding any significant communist activity in Portuguese Timor'. ${ }^{29}$ Similarly, in a telegram from the Department of State to the Embassy in Indonesia dated 20 September 1975, it was confirmed that 'the Indonesians have assurances from the Russians of nonintervention'. ${ }^{30}$ Moerdani was 'slightly less sure about the Chinese because of traffic between the substantial Chinese minority in Timor and Macau. In any event, there is little likelihood of effective Soviet or Chinese involvement' ${ }^{31}$ This is a point emphasized by James Cotton, who confirms that 'neither Australia nor even Indonesian policy makers spend much time on the grounds for this claim'. ${ }^{32}$ Indeed, Indonesia had expressed some desire to accommodate the Vietnamese communists. As Suharto informed Ford in 1975, there was the possibility that Vietnam, 'will apply Communism just within their borders in order to improve the conditions of their peoples. If so, we are okay'. ${ }^{33}$

\section{Indonesian expansionism and conquest}

The foregoing highlights the distinct possibility that Jakarta had interests in relation to East Timor that extended beyond securing state security in an uncertain regional environment. As Kiernan argues, 'the major Indonesian goal was conquest'. ${ }^{34}$ With conquest as a goal, 'Suharto secured US acquiescence in the territory's prospective incorporation by Indonesia. The expansionist impulse would simply be denied; the excuse, the communist threat'. ${ }^{35}$ This analysis is supported by the view of Prime Minister Lee of Singapore, who informed Dr Kissinger in a 1975 meeting that 'Indonesia wants to be a great military power' ${ }^{36}$ In Southeast Asia, Indonesia was recognized as 'the dominant and 
hegemonic power' with a 'strong sense of proprietary entitlement to order inter-state relations' ${ }^{37}$ Indonesia was aware that its position as regional hegemon, and its strategic location and pro-Western, anticommunist leanings, were vital for the US during and following its defeat in North Vietnam in 1975.

This sense of proprietary entitlement can be seen in Indonesia's relations with neighbouring territories. According to Ramos-Horta, 'West New Guinea was the first flagrant act of land-grabbing carried out by the Indonesian generals. Then as today, Indonesia, because of its vast natural resources and strategic location ... managed to win the acquiescence of major powers to its empire-building' ${ }^{38}$ While East Timor ostensibly appeared to be of little worth to Jakarta, seabed oil and gas reserves in the Timor Gap provided the possibility of rich future resources. Indeed, a seabed border agreement was negotiated between Indonesia and Australia in May 1971, which demarcated the area east of Timor. This area was roughly equidistant between the two countries, and contained a wealth of oil and gas deposits. ${ }^{39}$ This will certainly have factored into Indonesia's decision-making when contemplating the future of East Timor.

What is apparent is that the annexation of East Timor satisfied two key Indonesian interests. First, it reflected a security-based goal of denying external communist forces a potential regional ally. Second, it satisfied Indonesia's desire to maximize its regional power position through conquest and expansion. As a recently decolonized territory bordering the archipelago, Indonesia clearly had the most compelling interests at stake in the future of East Timor. These were arguably vital interests, affecting Indonesia's regional security and sense of prestige and power. With clear interests at stake in the territory, Jakarta increasingly sought to influence the final outcome of East Timor's bid for self-determination.

\section{Civil war in East Timor}

Due to weak support for Apodeti, the Indonesian government attempted to bribe or pressure the leaders of the various East Timorese parties to defend integration, although this failed to garner support. ${ }^{40}$ In light of the uncertain regional and international environment, FRETILIN and the UDT entered into a coalition in January 1975, a move supported by the Portuguese government. ${ }^{41}$ The aim of this coalition was to establish an independent East Timor. From the outset, Indonesia sought to undermine this coalition. It did so through a 
'campaign of de-stabilization' called Operasi Komodo, which began not long after the legalization of the East Timorese political parties in 1974. ${ }^{42}$ Operasi Komodo specialized in the dissemination of propaganda and disinformation within the East Timorese territory, with the sole purpose of inciting tension between the factions.

An important change had occurred in East Timor by April 1975. The UDT, dominated by landowning families, felt increasingly threatened by a number of FRETILIN's policies, such as land reform, which were increasingly popular with the Timorese citizens. ${ }^{43}$ These differences were seized upon by the Indonesian intelligence services, which 'fomented suspicion and conflict' between the parties. ${ }^{44}$ In early August 1975, the Vice President of the UDT travelled to Jakarta to meet with President Suharto's aide, General Ali Murtopo, before travelling on to Australia. ${ }^{45}$ Evidence suggests that Murtopo, in conjunction with the Indonesian intelligence agency, was able to play on UDT fears, and convince the UDT 'that FRETILIN was plotting an uprising to impose a 'communist-styled' regime on the island.' ${ }^{\text {'T }}$ The UDT leaders 'apparently concluded that Portuguese Timor's hopes for independence now depended upon curbing FRETILIN influence'. ${ }^{47}$ The UDT visit to Jakarta also angered FRETILIN leaders, who accused the UDT leadership of 'securing clandestine Indonesian support for UDT against FRETILIN in return for future Indonesian support in Timorese affairs'. ${ }^{48}$ Based on the information provided by Murtopo, the UDT leaders 'counter-charged that FRETILIN was acting in the interests of the Portuguese Communist Party'. ${ }^{49}$

By May 1975, the UDT had left the coalition. In July 1975, Suharto publicly stated that 'East Timor could not be independent, due to the alleged inviability of the territory in economic terms ... and that the future of East Timor lay in integration with Indonesia'. ${ }^{50}$ By August 1975, it was clear to policy makers in Australia that 'Indonesia was determined to invade East Timor, all that was wanting was an appropriate pretext'. ${ }^{51}$ Within East Timor, tensions increased throughout 1975. From March to July, the Portuguese authorities staged local village elections, with FRETILIN consistently gaining between 50-55 percent of the East Timorese vote. ${ }^{52}$ The results of the Timorese election prompted the Indonesian military to act, 'to check the Front's growing popular support'. ${ }^{53}$ The military orchestrated a UDT coup, which was launched on 11 August 1975.

In a show of force, members and supporters of the UDT coup seized key points in Dili and Baucau. In addition to weapons seized from the police arsenal, UDT also received Indonesian ground, air and naval gunfire support, which allowed the capture of Timorese districts such 
as Balibó and Maliana. ${ }^{54}$ There were also 'unconfirmed reports that Indonesia was providing vehicles and advisors to UDT forces ... and that areas falling under UDT control were being integrated into the administrative structure of West Timor'. ${ }^{55}$ Within days of the Dili coup, policy makers in Australia became aware that 'the coup makers acted with the foreknowledge of BAKIN, the Indonesian State Intelligence Organization'. ${ }^{56}$ Adam Malik reportedly pledged 'Indonesia's "full support, quietly or openly" to the four anti-FRETILIN parties, sometimes collectively referred to as the "Timorese anticommunist movement" in the Indonesian press'. 57

On 20 August, FRETILIN forces defeated a UDT force at Aileu, before moving onto Dili, which was captured seven days later, and Baucau, which was recaptured ten days later. FRETILIN were supported by troops from the Portuguese colonial army, which facilitated the establishment of Falantil (Armed Forces for the National Liberation of East Timor), a pro-independence military wing. ${ }^{58}$ Civil war raged between the UDT and Fretilin, with violent fighting leaving a predicted 2,000-3,000 people dead. ${ }^{59}$ On 23 August, the Portuguese Minister for Foreign Affairs contacted the UN, stating that 'the situation had deteriorated ... conditions in the capital had become chaotic; hundreds of inhabitants, including women and children, had been murdered'. ${ }^{60}$ The Portuguese administration withdrew from Dili on 27 August, retreating to Atauro Island. ${ }^{61}$ In doing so, it surrendered all authority and responsibility for the territory. ${ }^{62}$ From the beginning of September 1975, Fretilin had secured military control of the majority of East Timor. ${ }^{63}$ These events left Jakarta with two options: to accept an independent, FRETILIN-controlled East Timor at the Indonesian border, or to forcefully intervene and integrate the territory into the archipelago.

\section{ASEAN vanguard state - external power interest convergence}

Despite having clear interests at stake following the decolonization of East Timor, Indonesia had been reluctant to launch a full-scale invasion of the territory. As will be shown, Indonesia was in receipt of economic, military and domestic support from Western powers, which it was not willing to place in jeopardy. It therefore became vital to obtain great power acquiescence prior to invasion. As the vanguard state, Indonesia set out to obtain support from these major powers. Evidence will show that Australia and the US supported Suharto's East 
Timor policy 'so as not to offend the Soeharto [sic] government and because the West did not wish to see another piece of Southeast Asia fall to "communism" so soon after the fall of Saigon'. ${ }^{64}$

\section{Indonesia and the United States: the Ford Government (1974- 1977)}

By 1975, the 'domino theory appeared more real than perhaps at any time during the Cold War'. ${ }^{65}$ For the US, an expansionist Soviet Union consolidating power in Southeast Asia was a significant threat. Successive US governments viewed Indonesia as 'a bastion of antiCommunism and stability, a crucial source of resources, and one of the fastest growing sites in the world for US private investment' ${ }^{66}$ Kissinger confirmed the US position towards Indonesia in July 1974, stating that it needed 'Indonesia to play a more active stabilizing role in light of the reduction of our own presence in Southeast Asia'. ${ }^{67}$ Between 1966 and 1974, Washington had averaged over \$200 million per year in economic aid to Jakarta, and more than $\$ 20$ million in military assistance. ${ }^{68}$ Seeking strong allies in the East, Kissinger and Ford embarked on a 'renewed search for regional strongmen that Suharto skilfully exploited'. ${ }^{69}$ This is evident in US military aid to Indonesia, which increased from $\$ 20$ million in the 1960 s and early 1970 s, to nearly $\$ 43$ million in the year 1976. ${ }^{70}$ Between 1976 and 1979, the US furnished Indonesia with total military assistance of over $\$ 250$ million. $^{71}$

In 1973, the US suggested that 'Indonesia should play a larger role in Southeast Asian regional defence and that the US should begin increasing military assistance commensurate with that role' ${ }^{72}$ This suggestion was well received by Suharto, who in a meeting with Kissinger and Ford stated that his main goal was to combat communism, and he 'consistently (if mistakenly) described the independence movement of East Timor (FRETILIN) as communist-dominated' ${ }^{73}$ In light of recent events in Indochina, Ford and Kissinger were inclined to accept the veracity of Suharto's claims. By mid-1975, Suharto was able to use the US defeat in Vietnam to negotiate increased economic and military aid. During a meeting between General Suharto and President Ford at Camp David on 5 July, Ford informed Suharto that the US was 'able to make available some military equipment items to help you in your situation - four naval vessels ... some tanks, aircraft such as C-47, and four C-123 transports'. ${ }^{74}$ Suharto elaborated on Indonesia's regional problems, highlighting his concerns regarding communist military strength, 'fanaticism and ideology'. Suharto requested that 
the US agree 'to strengthen the [Indonesian] national resilience ... the most important need is not in the military field but in the economic area. This is where we must build the nation'. Ford agreed, stating that the US would do 'what we can do to supply those needs'.

Having secured increased economic and military aid, Suharto turned the conversation to East Timor, stating a preference for 'carrying out decolonization through the process of self-determination'. However, Suharto went on to state that 'with such a small territory and no resources, an independent country would hardly be viable ... if they want to integrate into Indonesia as an independent nation, that is not possible because Indonesia is one unitary state. So the only way is to integrate into Indonesia'. Suharto summarized his concern, stating that 'those who want independence are those who are Communistinfluenced. Those wanting Indonesian integration are being subjected to heavy pressure by those who are almost Communists ... I want to assert that Indonesia doesn't want to insert itself into Timor self-determination, but the problem is how to manage the selfdetermination process with a majority wanting unity with Indonesia'.

Having sown the seeds of communist threat in East Timor in the minds of Kissinger and Ford, 'Suharto returned from Washington on July 8 and made his first public statement suggesting that an independent East Timor was not viable'. ${ }^{75}$ It was only a few days later when UDT leaders launched their coup to suppress FRETILIN.

\section{The United States as a silent ally}

The US largely followed Indonesia's lead with regard to events in East Timor, opting for a silent partner approach. Concerned about the possible communist sympathies of Timorese political factions such as FRETILIN, the US deemed absorption into Indonesia to be the only viable policy available. As early as February 1975, US officials were aware that Indonesia had made the 'basic decision that an independent Timor, susceptible to communist influence would be [an] unacceptable threat to Indonesia's security, and that integration of Timor into Indonesia [was the] only acceptable long term solution'.$^{76}$ US recommendation at that time was a posture of 'maximum ... silence, avoiding any basis for suggesting either US encouragement or discouragement of Indonesian actions. ${ }^{77}$ In a memorandum from WR Smyser of the National Security Council Staff to Dr Kissinger on 4 March 1975, Smyser surmised 'the Indonesian Government fears that a hasty Portuguese pullout will leave a weakened Timor subject to the Left Wing instincts of a few leaders of 
the independence movement, leaders whom the Indonesians fear to be influenced by Peking. ${ }^{78}$ According to Smyser, 'President Suharto has developed programs to increase Indonesian influence in Timor through low-key political operations'. However, 'these programs have not been very successful. Because of that, there has been mounting pressure in Indonesia for direct military action'. According to Indonesian reports obtained by the US, 'preparations for such action are proceeding, and there is one report that Suharto has ordered incorporation of Portuguese Timor into Indonesia by no later than August, 1975, by force if necessary. Portuguese officials have told us they will not resist any Indonesian use of force'.

With events unfolding rapidly, US Ambassador Newsom 'recommended a general policy of silence ... arguing that we have considerable interests in Indonesia and none in Timor. If we try to dissuade Indonesia from what Suharto may regard as a necessary use of force, major difficulties in our relations could result'.$^{79}$ During a Secretary of State's staff meeting in Washington on 12 August 1975, Habib confirmed this approach, stating that 'I think it is a situation in which we should just do nothing. It is quite obvious that the Indonesians are not going to let any hostile element take over an island right in the midst of the Indonesian archipelago' ${ }^{80}$ Similarly, in a Secretary of State meeting on 8 October 1975, Habib confirmed that 'it looks like the Indonesians have begun the attack on Timor ... I think what we are doing is like Jack - keeping our mouth shut about the thing' ${ }^{81}$ When asked by Kissinger if that was conceivable action to take, Habib replied 'we've been doing it, so I think it's quite conceivable'. ${ }^{82}$

However, Suharto still remained cautious about launching a full-scale invasion. Suharto's main concern was that invasion might jeopardize 'the long-term US military assistance that the armed forces were counting on to undertake their plans for military modernization'. ${ }^{83}$ This stance was confirmed in a telegram from the Embassy in Indonesia to the Department of State on 16 August 1975. The telegram confirmed Suharto's 'apprehension' over the US reaction, with General Murdani of the Indonesian army intelligence stating that the President 'realized that if Indonesia invaded Timor, [the] results of [the] Camp David meeting would be lost' ${ }^{84}$ Murdani was informed that the 'US [was] not opposed to incorporation of Timor but hoped peaceful alternatives could be found' ${ }^{85}$ In a meeting between Dr Kissinger and Adam Malik on 5 September 1975, Kissinger sympathized with the Indonesian position, informing him that he "had always assumed that in about ten years or so Indonesia would take over Portuguese Timor - for symmetry! I will not spend any sleepless nights over it'. ${ }^{86}$ Malik 
stressed that 'in Timor things are moving very quickly. We could use your help ... with the Portuguese. Maybe you could talk to them ... we hope the non-communists will come out on top ... the delegation will be going over our military needs and our priorities'. Kissinger concluded that he had 'always been in favor of a decent military aid level for Indonesia. You can count on it'.

\section{Ford and Suharto meeting, December 1975}

Relations between the US and Indonesia continued to develop positively, with the establishment of a joint US-Indonesian Consultative Commission signed in November 1975. This culminated in a meeting between General Suharto, President Ford and Dr Kissinger on 6 December 1975. Dr Kissinger prepared President Ford for this meeting in a memorandum sent 21 November 1975, informing Ford that 'your Jakarta visit will be a dramatic reaffirmation of the significance we attach to our relations with Indonesia, the largest and most important non-Communist Southeast Asian state'. ${ }^{87}$ The US goal was therefore to 'focus our dialogue increasingly on broader issues of continuing major interest of the two governments: the US role and US interests in East Asia, both for their own sake and to balance Soviet and PRC [People's Republic of China] pressures'. Kissinger continued to state that 'in the post-Vietnam environment, US interests in Indonesia are based both on its present position in the region and, especially, on its anticipated future role ... its geographic location and resources are of major strategic importance in the region'.

With regard to East Timor, Kissinger stated that 'Jakarta has become concerned that the backward and resource-poor colony would attain what the Indonesians expect would be a weak, unviable independence leaving it susceptible to outside - especially Chinese - domination ... a merger with Indonesia is probably the best solution for the colony if the inhabitants agree'. Having been suitably briefed by Kissinger, Ford met Suharto on 6 December. The meeting specifically focused on US and Indonesian uncertainty following the end of the Vietnam War. Suharto turned the conversation to East Timor, asking Ford for US 'understanding if we deem it necessary to take rapid or drastic action [in East Timor]'. ${ }^{88}$ Ford replied that 'we will understand and will not press you on the issue. We understand the problem you have and the intentions you have'. Kissinger highlighted the US concern regarding Indonesian use of US arms during the invasion, but ultimately stressed 
that 'whatever you do succeeds quickly. We would be able to influence the reaction in America if whatever happens happens after we return'.

This conversation highlights US concerns regarding the regional environment, and the importance of Indonesia to the US in its regional strategic calculations. Evidence suggests that Indonesia sought to maximize its regional power, commensurate to that role. Clearly, the US made a conscious decision to aid Indonesia in its policy towards East Timor. The US 'was grateful for political support and corporate access to what President Nixon called "by far the greatest prize in the South-East Asian area" and was glad to do a painless ... favour for a loyal friend'. ${ }^{89}$ The meeting between Ford and Suharto was instrumental in removing any residual concerns Suharto had regarding a potentially negative response to invasion by the US government.

\section{Indonesia and Australia: a most important neighbour}

Australia's positioning in relation to Indonesia meant that a friendly relationship was vital to Canberra's security and defence. In the 20th century, Indonesia has been instrumental in providing 'a strategic shield to Australia's vulnerable and sparsely populated northern approaches'. ${ }^{90}$ At the height of the Cold War, this strategic shield was of significant importance, preventing potential intervention from external powers. Because Indonesia had the 'capacity to disturb or enhance the regional balance of power, because Indonesia can facilitate or check Australia's entrée to regional political forums and because of great power interests in Indonesia, Australian diplomats have been loath to offend Indonesia'. ${ }^{91}$ Instead, Australia has been confronted with the challenge of how to 'reconcile its Western origins with its Asian geography in creating a viable security identity'. ${ }^{92}$ Australia has sought to address this issue through stable relations with Indonesia. Within Canberra, it was believed that maintaining Indonesia's territorial integrity was 'the best way of maintaining geopolitical 'stability' in Australia's corner of Southeast Asia'. ${ }^{93}$ In such a diverse nation, Suharto's firm control of the archipelago, especially his anti-communism and intolerance of separatism, was accepted as the key to Australia's own territorial security. ${ }^{94}$ Indonesia was "viewed as a staunch anti-communist regime that was a positive force for regional stability and moderation'. ${ }^{95}$ Richard Woolcott, who became Australian Ambassador in March 1975, admitted taking a 'pragmatic or realist approach to international affairs' in his dealings with Indonesia. ${ }^{96}$ Woolcott argued that if Indonesia were 'intent on a policy of [East Timor] absorption ... Australia [was] in no 
position to deny that intention, any effort [would] only cause harm to a bilateral relationship so important to Australia's security'. ${ }^{97}$

While a positive bilateral relationship with Indonesia was an important interest for Australia, this does not mean that Canberra did not have wider geopolitical concerns regarding the Cold War regional environment in 1975. In an Australian government memorandum regarding the strategic significance of Timor to Australia and its relation to a major power threat, it was stated that 'access specifically to Portuguese Timor by a major power would: greatly facilitate the application of strategic pressure against Indonesia to make additional base areas in eastern Indonesia available to it. Indonesia might well be susceptible to such pressure; seriously prejudice the potential military capability of Australia or its allies to support Indonesia against such pressure; and enable the development of air bases which would enhance a major power's operational capabilities'. ${ }^{98}$ Canberra was also of the opinion that endorsing Indonesian actions in East Timor would open the Australian government to oil and gas drilling rights in the region's waters. ${ }^{99}$ As Minister in the Australian Embassy in Jakarta, John McCredie stated that 'Indonesian absorption of Timor makes geopolitical sense. Any other long-term solution would be potentially disruptive of both Indonesia and the region. Its [absorption] would help confirm our seabed agreement with Indonesia'. ${ }^{100}$ As previously highlighted, the Timor Gap is rich in oil and natural gases. The seabed border agreement negotiated between Indonesia and Australia in May 1971 to delimit the area east of Timor held the promise of vast future gains. ${ }^{101}$ It is apparent from Australian documents that Timorese oil was a major interest. In a submission to Australian Minister for Foreign Affairs Don Willesee in May 1974, it was confirmed that Australia had direct interests in Timor, with oil specifically referred to at that time. ${ }^{102}$

As will be shown, successive Australian governments assumed a position on Indonesia's East Timor policy that conformed to these core state interests. Prime Minister Gough Whitlam made it clear to Suharto that he supported the integration of East Timor into the Indonesian archipelago. Despite a succeeding Fraser government initially criticizing this approach, once in office, there was little change to this policy. Australia's geo-strategic interests were to take precedence over independence for East Timor. 


\section{The Whitlam Government (December 1972-November 1975)}

Australian Prime Minister Gough Whitlam played a vital role in supporting and enabling Suharto's East Timor policy. Within Canberra, 'Timor policy was ... Whitlam policy'. ${ }^{103}$ Whitlam had a 'principled aversion to mini-states', and believed that it 'was better to have one neighbour [Indonesia] to deal with than a proliferation of small countries'. ${ }^{104}$ According to this view, an independent East Timor would only succeed in destabilizing the region and its neighbours. Whitlam also perceived 'the separation of West and East Timor as a legacy of colonialism, and indicated he was prepared to dismiss East Timorese claims for independence in order to rectify this "colonial accident'" ${ }^{105}$

As part of an East Timor enquiry conducted by the Australian Senate Foreign Affairs, Defence and Trade, Whitlam testified that he had inherited his view of East Timor from preceding governments. ${ }^{106}$ The Menzies government (1949-66) believed that Portuguese Timor would inevitably become the object of Indonesian attention, and that this was only a matter of time and could not be prevented. Mr Whitlam told the Committee that analysis of this period 'came to the same conclusion, that East Timor was non-viable politically and economically'. ${ }^{107}$ This belief underscored Whitlam's approach to East Timor, which was articulated in a meeting with President Suharto in September 1974. Prior to Whitlam's meeting with Suharto, Senator Willesee, Australian Minister for Foreign Affairs, 'approved a policy that gave emphasis to self-determination for the East Timorese people'. ${ }^{108}$ At the meeting, however, Whitlam took a different line to the brief. This was to have significant consequences for Australia's future East Timor policy.

At the September meeting, Whitlam informed Suharto that "first, he believed that Portuguese Timor should become part of Indonesia. Second, this should happen in accordance with the properly expressed wishes of the people of Portuguese Timor' ${ }^{109}$ Whitlam emphasized 'that this was not yet Government policy but that it was likely to become that'. Whitlam stated his belief that 'Portuguese Timor was too small to be independent. It was economically unviable. Independence would be unwelcome to Indonesia, Australia and to other countries in the region, because an independent Portuguese Timor would inevitably become the focus of attention of others outside the region'. The Australian Department of Foreign Affairs prepared a background paper, dated 11 September 1974, to take account of the approach adopted by Whitlam during his meeting with Suharto. In the paper, it 
stated that Australia 'shares [Indonesia's] belief that the voluntary union of Portuguese Timor with Indonesia, on the basis of an internationally acceptable act of self determination, would seem to serve the objective of decolonization, and at the same time the interests of stability in the region'. ${ }^{110}$ Whitlam 'dismissed advice that by acquiescing in Indonesian demands he was in fact encouraging a hardline faction led by Ali Murtopo and other generals'. ${ }^{111}$ This was despite evidence that 'already for some months previously the Indonesians had settled on a policy of incorporation'. ${ }^{112}$

Whitlam met with Suharto again in April 1975, at Townsville, Queensland. At this meeting, Whitlam told Suharto that 'he still hoped that Portuguese Timor would be associated with or integrated into Indonesia; but this result should be achieved in a way which would not upset the Australian people'. ${ }^{113} \mathrm{He}$ informed Suharto that 'the majority of the people of Portuguese Timor had no sense of politics, and that in time they would come to recognize their ethnic kinship with their Indonesian neighbours'. President Suharto informed Whitlam that while Indonesia 'had no territorial ambition to include the territory of Portuguese Timor into the Republic of Indonesia', Jakarta had 'concluded that integration with Indonesia was the best solution'.

In a bid to support Jakarta, Canberra refused to assist the FRETILIN administration that was established in Dili following the UDT coup. ${ }^{114}$ José Ramos-Horta, Foreign Minister and founder of FRETILIN, travelled to Australia with the hope of getting the Australian Consulate in Dili reopened, only to be informed by Canberra that this would not be possible, as it would offend the Indonesians. ${ }^{115}$ As Ambassador Woolcott confirmed in a letter dated 24 September to Canberra Times journalist Bruce Juddery: 'the alternatives now seem to be a de facto FRETILIN Government or the integration of East Timor into Indonesia. Neither will involve a genuine act of self-determination ... basically, this situation is Portugal's - not Indonesia's - fault. Given this Hobbes choice, I believe Australia's interests are better served by association with Indonesia than by independence'. ${ }^{116}$

Similarly, in a leaked August 1975 telegram, Woolcott stated that 'we leave events to take their course, and act in a way which would be designed to minimize the public impact in Australia and show private understanding to Indonesia of their problems. I am recommending a pragmatic rather than a principled stand but that is what national interest and foreign policy is all about'. ${ }^{117}$

Australian support for Indonesia was not merely tacit in nature. From the Whitlam government onwards, a pro-active role was taken 
whereby Australia "'neutralized" negative public opinion about Indonesia $\ldots$ and aided Indonesia in the diplomatic sphere'. ${ }^{118}$ One example of this is Australia's continued support for Indonesia following the killing of five Australian journalists at Balibó in 1975. In the process of monitoring Indonesian military radio, Australian intelligence had become immediately aware that Indonesia's Kopassandha troops were responsible for the attack. These troops, among others, had received substantial military training by the Australian, British and US governments. ${ }^{119}$ Nevertheless, 'far from criticizing Indonesia or demanding a proper investigation of the killings, Australia sought to deflect attention from the available evidence'. ${ }^{120}$ Canberra 'publicly accept[ed] the false Indonesian claim that the "Balibó Five" had been caught in the crossfire during a battle between FRETILIN and UDT forces'. ${ }^{121}$ According to James Dunn, 'the fact that ... we did not even protest was to the Indonesian military a green light'. ${ }^{122}$ Dunn confirmed that Whitlam 'astonished the Indonesians by making it very clear [in 1974] that his preferred solution was that East Timor go to Indonesia ... the Indonesians didn't expect Australia to be so generous. Whitlam's words encouraged the military to believe that this was the way to go'. ${ }^{123}$

\section{The Fraser Government (November 1975-March 1983)}

By 11 November 1975, Malcolm Fraser had been appointed to replace Whitlam as Prime Minister. According to Whitlam, this change in leadership constituted 'the last refraining influence on Indonesian action'. ${ }^{124}$ After this date, 'Australia had a Government which, in Indonesian eyes, shared its suspicion of communist insurgency, and would plainly welcome any action to supress it'. ${ }^{125}$ Indeed, Fraser did appear more concerned about communist influence than Whitlam. Fraser depicted 'the Soviet Union as bent on preponderance', and argued that 'the Soviet Union still seeks to expand its influence throughout the world in order to achieve Soviet primacy'. ${ }^{126}$

Despite an apparent joint concern with Indonesia regarding communist influence in the region, the Fraser government set out to publicly distance itself from Indonesia's actions in East Timor. On 26 November 1975, Mr Fraser indicated that his caretaker government 'would do nothing about reported Indonesian bombings in East Timor ... the tragic events that were occurring were a direct result of the barrenness of the foreign policy of the Whitlam Government, which the caretaker Government had to continue'. ${ }^{127}$ Australian 
Minister for Foreign Affairs, Andrew Peacock, also 'initially took a pro-independence stand and was highly critical of the Whitlam government's handling of the entire East Timor issue and acquiescence in Indonesian policy'. ${ }^{128}$ However, evidence suggests that this was little more than public posturing. On 2 October 1975, Peacock stated in Parliament: 'we understand Indonesia's concern. The events of the civil war in Timor are taking place in an area at the end of the Indonesian island archipelago. Who can doubt the concern that Indonesia must feel'. ${ }^{129}$ The Indonesian government 'took the statement as an assurance that an incoming Fraser government would maintain continuity with the Timor policy of the Whitlam government'. ${ }^{130}$

Peacock reinforced this statement in a meeting with Mr Harry Tjan of the Jakarta Centre for Strategic and International Studies, and Mr Lim Bian Kie of General Moerdani’s Special Operations Group, on 24 September 1975. An Indonesian record of the meeting stated: 'Mr Peacock and his party would not protest against Indonesia if Indonesia is forced to do something about Portuguese Timor, for example to "go in" to restore peace there ... basically he respects Whitlam's policy in this Portuguese Timor problem, and he is personally of the same opinion'. ${ }^{131}$ This disclosure by Indonesian officials of 'the accommodating nature' of Peacock, while on holiday in Bali in September 1975, 'was strongly denied by Peacock when he was questioned about the matter in the federal parliament'. ${ }^{132}$

In addition to support from Peacock, a message from Prime Minister Fraser, delivered to President Suharto on 25 November 1975, 'had been taken by the Indonesians as supportive of their actions in Timor'. ${ }^{133}$ The message referred to 'the great importance which Mr Fraser attaches to Australia's relations with Indonesia' ${ }^{134}$ It went on to say: 'the Prime Minister ... recognizes the need for Indonesia to have an appropriate solution for the problem of Portuguese Timor'. Suharto is reported to have 'greatly appreciated' the Prime Minister's message, stating that 'Indonesia too attached great importance to its relations with Australia'. With regard to Timor, Suharto stated that 'he was very pleased Mr Fraser recognized the need for Indonesia to have an appropriate solution of the Timor question. He said there was 'no change' in Indonesian policy. Portuguese Timor should be decolonized 'properly'. Indonesian interests however needed to be taken into account'.

According to Whitlam, 'from 11 November Indonesia knew that any "anti-Communist" action she took would have support in Canberra'. ${ }^{135}$ Whitlam also alleged that Fraser knew beforehand that Indonesia planned to invade East Timor. This was a 'result of his 
knowing that Australians were evacuated a couple of days before'. ${ }^{136}$ Fraser and the Leader of the National Country Party, Mr Anthony, stated 'if one thing was better calculated than anything else to incite the Indonesians to take action ... it was the fear that there would be communist control in East Timor'. ${ }^{137}$

\section{Summary: Indonesia obtains great power commitments}

What is clear from the foregoing discussion is that obtaining Washington and Canberra support for Indonesia's East Timor policy gave Suharto the confidence to act. As the vanguard state, Indonesia was able to utilize the environment in Southeast Asia in 1975 to gain great power commitments to secure its own interests. Both the United States and Australia relied on strong relations with Indonesia, to secure their own vital interests in an uncertain Cold War regional environment. Stable relations with Indonesia enhanced regional security and offered gains with respect to enhanced power. The securing of vital interests took precedence over the independence of a territory believed to be 'too small, backwards and isolated to survive on its own'. ${ }^{138}$ By late November 1975, Jakarta was confident that a full-scale invasion of East Timor would not result in an international backlash, or any external power interference.

\section{ASEAN institutional cohesion}

It was not only external power backing that Suharto was anxious to obtain in advance of a full-scale invasion of East Timor. Regional support was also a vital component in Indonesia's plans. By obtaining unanimous support within ASEAN, Suharto could portray a united regional front with respect to Indonesian actions in East Timor. A united ASEAN could help to deflect any unwanted international attention, and lend the invasion an appearance of legitimacy. As early as 1974, Suharto took steps to realize this goal. To understand ASEAN state responses to Indonesia's East Timor policy, it is beneficial to consider the history of the Association, and the regional environment in which it found itself in 1975.

Suharto began his presidency with a desire to establish improved relations with neighbouring states, as evidenced by the creation of ASEAN on 8 August 1967, less than six months into his presidency. The establishment of the Association also came one year after President 
Suharto ended former President Sukarno's policy of Konfrontasi with Malaysia. For the remaining founders of ASEAN, the formation of the Association was a way to draw Indonesia 'into a limited security community', ${ }^{139}$ thus preventing another 'confrontation' occurring between Indonesia and the ASEAN states. Indonesian intervention in East Timor came only eight years after ASEAN's establishment. There was the possibility that open criticism of Indonesia could jeopardize improved regional relations. As such, any ASEAN state unease regarding Indonesia's East Timor policy was 'muted by the dictates of realpolitik'. ${ }^{140}$

An uncertain regional environment compounded this problem. Vietnamese communist expansion, with Soviet backing, was a primary fear for the ASEAN states. In June 1975, two months after US defeat in North Vietnam, Philip Habib visited Southeast Asia. In a memorandum from Dr Kissinger to President Ford summarizing the trip, Kissinger stated that 'in each country it is believed that Hanoi's success in Indochina has brought about a fundamental power shift in the region. All the Southeast Asian countries fear Hanoi, which they now see as a major force in the sub-region with plenty of arms, revolutionary zeal and the momentum of success'. ${ }^{141}$ A vulnerable and independent Timor could invite intervention by external powers, and as such was met with much regional consternation. ${ }^{142}$

As early as September 1974, Malaysia had been in support of Indonesia's policy of integration with East Timor. Officials argued that if an independent East Timor 'becomes a communist stronghold, it will endanger the security in the Southeast Asian region'. ${ }^{143}$ The Indonesian invasion was also supported by the Philippines, which stated the belief that 'the people of Portuguese Timor had invited Indonesia to help them"144 and cautioned that a "power vacuum ... would threaten peace in the region'. ${ }^{145}$ According to ASEAN officials, 'Chinese and Soviet support for the FRETILIN group in East Timor might slow the growing friendship between ASEAN countries and the two communist nations'. ${ }^{146}$ As such, the ASEAN members 'were closely watching moves by China and the Soviet Union on the Timor issue, to see if these would be followed by material assistance, including arms.. ${ }^{147}$

It is also important to note that the annexation of small neighbouring territories was not an unusual occurrence in the Southeast Asian region. Indonesia annexed Aceh in 1949 and West Papua in 1969. This resulted in independence movements and attempts at secessionism, which represented an internal and external threat. Secessionism of various ethnic groups, such as the Patani United Liberation 
Organization (PULO) in Southern Thailand, and the Moro Islamic Liberation Front (MILF) in the Southern Philippines, have also waged long-running campaigns for independence. This meant that many regional states could relate to Indonesia's predicament following decolonization in East Timor, and had some sympathy for Indonesia's situation. Indeed, evidence suggests that Malaysia's staunch support for Indonesia's East Timor policy was due to designs Kuala Lumpur had on neighbouring Brunei. Malaysia believed Brunei should become another state in its own federation, despite Brunei's strong opposition to the plan. ${ }^{148}$ Brunei's integration with Malaysia was attractive to Kuala Lumpur, due to 'Brunei's awkward geographical position in the middle of Malaysia's north Borneo territories', and because 'it possesses oil reserves ... and the Sultan holds very substantial sterling cash reserves'. ${ }^{149}$ It was reported in Australia that 'the possibility of a Malaysian takeover of the state may cast some light on recent Malaysian statements on the crisis in East Timor. One Government spokesman recently described the FRETILIN party, which has the upper hand in East Timor, as 'communist' and said the Government supports Indonesia's position'. ${ }^{150}$

For Malaysia to realize its territorial ambitions in Brunei, 'Indonesian approval would be a necessity. The Malaysian stand on Timor might be seen as part of an exercise in mutual self-help'. ${ }^{151}$ This view is supported in a telegram sent from the Embassy in Kuala Lumpur to the Secretary of State in Washington in September 1975, in which Australian and US officials expressed the view that 'GOM [Government of Malaysia] would back Jakarta politically ... in addition to close military-security ties maintained between GOM and GOI since Suharto came to power, Malaysians in past two years have given increasing indications of wanting to absorb Brunei at some future date thus would find it in own interests to support Timor take-over'. ${ }^{152}$ According to Gough Whitlam, Australia's Minister for Foreign Affairs, Andrew Peacock 'had been under the illusion that Indonesia could be influenced through her partners in ASEAN ... the ASEAN countries soon disabused him ... It had become clear to me that ASEAN would not become involved after I had spoken to Lee Kuan Yew in Singapore on 8 August 1975 and to Tun Razak in Canberra in mid-October'. ${ }^{153}$ During a meeting with Lee Kuan Yew in August 1975, Whitlam reportedly asked 'whether Australia and Singapore, as members of the Five-Power Agreement and the Commonwealth, and as neighbours of the area, should confer about East Timor'. ${ }^{154}$ However, 'Mr Lee would not have anything to do with the proposition'. ${ }^{155}$ The October 1975 meeting between Razak and Whitlam was summarized in a telegram 
from the Embassy in Canberra to the Secretary of State in Washington. It stated: 'Both Whitlam and Razak expressed support for eventual Indonesian takeover of Timor. Both agreed not to criticize recent Indonesian military steps and expressed regret that [Indonesia] hadn't acted more promptly following Portuguese pull out'. ${ }^{156}$

In its bid to aid Indonesia, Malaysia hosted Apodeti leadership, the Timorese political faction advocating integration with Indonesia. Malaysia also disseminated anti-FRETILIN propaganda, and supplied weapons to Indonesian special force troops. ${ }^{157}$ Indonesia's Foreign Minister, Adam Malik, and Malaysia's Prime Minister Razak began issuing statements about Timor becoming a base for communist subversion. ${ }^{158}$ Malaysia 'even broadcast support for the decision of Indonesia to send troops to East Timor'. ${ }^{159}$ A telegram from the Indonesian Embassy to the Secretary of State in Washington summarized the ASEAN response to events in East Timor. It stated that 'ASEAN neighbours would probably react mildly, perhaps even expressing "understanding" of Indonesian concerns ... (indeed, there are reports Malaysia has urged [Indonesia] to seize Portuguese Timor quickly)'. ${ }^{160}$

Ultimately, concerns regarding the regional environment, coupled with a desire to maintain good relations with Indonesia, meant that the ASEAN states were not going to oppose Indonesian actions in East Timor. Support for Indonesia could also help achieve regional state interests regarding other neighbouring territories. The various ASEAN states voiced their support for Indonesia, and coupled with external power support, Suharto was now in a position to act and launch a full-scale invasion of East Timor.

\section{Indonesia's invasion of East Timor (December 1975)}

East Timor's civil war provided Indonesia with the pretext it had been waiting for to intervene in the territory. Blaming the civil violence on FRETILIN, and wary of losing East Timor to independence, Suharto began preparations for a full-scale military intervention. It was reported, on 4 September 1975, that special Indonesian troops had been sent into East Timor to fight FRETILIN, infiltrate and organize UDT and Apodeti, and to encourage pro-Indonesian sentiments. ${ }^{161}$ On 7 October, Indonesia captured the border city of Batugadé, as well as nearby Balibó. In an effort to prevent Indonesia from furthering its plan of annexation, FRETILIN unilaterally declared independence for the Democratic Republic of East Timor on 28 November. It 
received recognition from twelve nation-states, but not the Portuguese government. This meant that the UN continued to recognize Portugal as the legitimate administrative authority in East Timor. ${ }^{162}$

Two days after East Timor's declaration of independence, the Indonesian government influenced members from four East Timorese parties: the UDT, Apodeti, the KOTA and Trabalhista, to sign the Balibó Declaration, which sought integration with Indonesia. ${ }^{163}$ Indonesia was therefore able to use the Balibó Declaration to justify its occupation of East Timor as being in the interests of the Timorese majority. Indonesia launched a full-scale invasion of East Timor on 7 December 1975, less than 24 hours after Suharto's meeting with President Ford in Jakarta. By noon, Indonesian troops had taken Dili, after combat with FALINTIL, the armed military wing of FRETILIN. Observers stated that 'warships shelled Dili before dawn [on 6 December] ... Indonesian paratroops began shooting down people in the streets as soon as they landed'. ${ }^{164}$ A second invasion on 10 December led to the seizure of Baucau, East Timor's second largest town. By April 1976, some 35,000 Indonesian soldiers, onetenth of the Indonesian National Armed Forces (TNI), occupied the Portuguese colony and further subjected it to Indonesian rule. ${ }^{165}$ Ninety percent of Indonesian armed forces utilized US equipment at this time. ${ }^{166}$

Heavily outnumbered, FALINTIL troops fled to the mountains, where they began guerrilla warfare operations. In the first year of Indonesian occupation, it is believed 60,000 East Timorese were killed, averaging 10 percent of the population. ${ }^{167}$ According to Kiernan, the invasion and subsequent occupation took the lives of 21-26 percent of the country's population. ${ }^{168}$ It is believed that the majority of these deaths occurred in the first five years of occupation, with between 116,000 and 174,000 killed. ${ }^{169}$ The list of atrocities carried out by the TNI is vast, including massacres, public executions, rape, torture, starvation, political imprisonment, forced sterilizations, enforced marriages, and destruction of fields and villages using bombs and napalm. ${ }^{170}$ During this period, nearly all of the major FRETILIN leaders were killed or captured. Indonesia's 'extensive and indiscriminate killing' succeeded in alienating the population, 'giving FRETILIN wide popular support'. ${ }^{171}$ James Dunn, former Australian consul in East Timor, reported that refugee accounts 'of Indonesia's behaviour in East Timor, suggest that the plight of these people might well constitute, relatively speaking, the most serious case of contravention of human rights facing the world at this time'. ${ }^{172}$ 
Indonesian incorporation of East Timor as the 27th province of the Republic was formally completed on 18 July $1976 .{ }^{173}$ Ali Alatas, Indonesia's Ambassador to the UN and future Foreign Minister, summarized the Indonesian position, stating that Indonesia only entered Timor, 'after Portugal's precipitate abandonment of the territory and its failure to fulfil its responsibilities as administering authority, and in the face of FRETILIN's mounting reign of terror against its own people'. ${ }^{174}$ For the next 25 years, the Indonesian government would claim that the majority of East Timorese supported integration, a claim unverifiable due to a ban on foreign journalists.

\section{Invasion repercussions: Indonesian resistance to sovereignty violation}

The Indonesian invasion of East Timor violated two principles of international law: the principle that states shall refrain in their international relations from the threat or use of force against the territorial integrity or political independence of any state; and the principle of self-determination of peoples. ${ }^{175}$ According to a representative of Portugal, Indonesian military aggression in East Timor 'had abruptly altered the course of the decolonization process which should and could have been concluded peacefully'. ${ }^{176}$ Portugal chose to sever diplomatic relations with Indonesia, and to call for an end to Indonesian intervention. ${ }^{177}$ On 12 December 1975 the UN General Assembly adopted Resolution 3485 by a recorded vote of 72 to 10 with 43 abstentions. Within this Resolution, the General Assembly 'strongly deplored the military intervention of the armed forces of Indonesia in Portuguese Timor [and] called upon Indonesia ... to withdraw without delay its armed forces from the territory'. ${ }^{178}$

The Portuguese Government also requested an urgent meeting of the UN Security Council, 'to bring an end to the military aggression by Indonesia and to establish conditions that would enable the decolonization process to continue'. ${ }^{179}$ The Security Council considered the question of Timor at five meetings held between 15 and 22 December 1975. José Ramos-Horta, who said he was speaking on behalf of the Central Committee of FRETILIN and of the Government of the Democratic Republic of East Timor, said that he did not deny the existence of a certain common cultural and ethnic origins of the peoples of East Timor and Indonesia, but he refused to consider it as sufficient reason for integration of the territory into Indonesia. ${ }^{180}$ Ramos-Horta called on 'the Security Council to 
condemn Indonesia's aggression and to send a fact-finding mission to assess the situation in East Timor and enforce the decisions of the United Nations'. The Security Council adopted Resolution 384, which 'deplored the intervention of the armed forces of Indonesia in East Timor'. ${ }^{181}$ The Council also 'requested the Secretary-General to send urgently a special representative to East Timor to make an onthe-spot assessment of the situation and to establish contact with all the parties in the territory and all states concerned in order to ensure the implementation of this resolution'. ${ }^{182}$

On 12 March 1976, Special Representative, Vittorio Winspeare Guicciardi, entered East Timor to assess the situation and to establish contact with the parties. Winspeare noted that the Government of the Democratic Republic of East Timor 'had suggested a referendum with a choice between independence and integration with Indonesia ... Indonesia had maintained that the decision of the Provisional Government for integration with Indonesia should be subjected to ratification by East Timor people'. ${ }^{183}$ In the UN General Assembly, the US 'abstained in 1975 and voted against every East Timor resolution for the next seven years' ${ }^{184}$ As Daniel Patrick Moynihan, US Ambassador to the UN in 1975-76 confirmed in his memoirs, the US 'wished things to turn out as they did [in East Timor], and worked to bring this about. The Department of State desired that the United Nations prove utterly ineffective in whatever measures it undertook. This task was given to me, and I carried it forward with no inconsiderable success'. ${ }^{185}$ This approach, adopted by a number of influential Western powers, prevented the UN from providing an effective response to the crisis. Between 1977 and 1980, 'the US and other supporters of Jakarta ... worked to remove East Timor from the agenda of the UN decolonization committee'. ${ }^{186}$

Despite UN resolutions remaining in force throughout Indonesia's occupation of East Timor, from 1982 onwards, consideration of the East Timor issue was effectively muted. Very few states came out in support of East Timor. China, which 'was still committed to supporting anticolonial movements in the developing world', endorsed FRETILIN's declaration of independence. ${ }^{187}$ After the invasion, the FRETILIN leader, Xavier do Amaral, 'declared that China would henceforth speak on behalf of East Timor at the UN'. ${ }^{188}$ Although China went on to act as 'East Timor's primary patron', supplying diplomatic and financial support, even this had 'waned by 1978 when it [China] needed ASEAN support to fight the Vietnamese'. ${ }^{189}$ 


\section{The Ford Government (August 1974-January 1977)}

The Ford government's initial response to Indonesia's invasion of East Timor was to delay any further arms sales pending a review by the State Department. ${ }^{190}$ Use of US arms in the invasion of East Timor violated a 1958 treaty between the US and Indonesia limiting the use of US-supplied weapons to 'legitimate self-defence'. ${ }^{191}$ Kissinger and his officials were aware that the invasion of East Timor did not fall within the scope of the arms treaty. Kissinger complained: 'And we can't construe a Communist government in the middle of Indonesia as self-defence ... I know what the law is but how can it be in the US national interest for us to ... kick the Indonesians in the teeth?' ${ }^{192}$ In accordance with Kissinger's view, military equipment continued to flow to Indonesia. ${ }^{193}$ During the six-month review period undertaken by the Department of State, the US 'made four new offers of military equipment sales to Indonesia including maintenance and spare parts for the Rockwell OV-10 Bronco aircraft, designed specifically for counterinsurgency operations and employed during the invasion of East Timor'. ${ }^{194}$ In a February 1976 memorandum to Brent Scowcroft, the President's Assistant for National Security Affairs, Ambassador Newsom's concerns were expressed with regards to military supply to Indonesia. It stated that 'congressional action could end ... military assistance to Indonesia', and as such the state should 'undertake a discreet survey of possible alternative measures to insure that Indonesia would still have access to American equipment'. ${ }^{195}$ In the Secretary of State's Staff Meeting on 17 June 1976 Mr Habib stated that the US had 'not objected in UN Security Council debates', and as such the Indonesians were 'quite happy with the position we've taken. We've resumed, as you know, all of our normal relations with them; and there isn't any problem involved' ${ }^{196}$ Kissinger replied, 'not very willingly. Illegally and beautifully'. ${ }^{197}$

\section{The Carter Government (January 1977-January 1981)}

The Carter administration largely continued the Ford Administration's East Timor policy, despite a 'professed commitment to human rights'. ${ }^{198}$ The US Congress criticized Indonesia's invasion and occupation of East Timor as being illegal. However, Michael Armacost of the US National Security Council Staff stated in June 1977, that 'the Indonesian decision is irreversible ... the US government has accepted it. Continued congressional hearings are regarded as 
unwarranted and mischievous interference in their [the Indonesians] internal affairs' ${ }^{199}$ In mid-1977, Carter administration officials blocked attempts made by US Congressman Don Fraser to obtain a copy of the Ford-Suharto meeting in $1975 .{ }^{200}$ In April 1977, a congressional delegation led by Lester Wolff visited East Timor. Indonesian military officials escorted Wolff on a 'staged tour of the capital, Dili, during which they were greeted by cheering crowds and met with handpicked Timorese collaborators'. ${ }^{201}$ Upon returning to Washington, Wolff blamed Timorese deaths on FRETILIN guerrillas, stating that 'the Indonesians should have entered the fray much earlier and perhaps more lives could have been spared'. ${ }^{202}$

Indonesia's request for military aid in 1978 'amounted to twice the quantity of aid the Ford administration had supplied'. ${ }^{203}$ US Vice President Walter Mondale met with Suharto in May 1978, with Suharto reported to have 'very much appreciated [US] approval of the F-5 sale ... but of more immediate importance, it needs a squadron of A-4s and a light arms factory', all of which Mondale confirmed had been approved. ${ }^{204}$ With regard to East Timor, Mondale 'reaffirmed that the Carter administration accepted the position of its predecessor and that it does not question the incorporation of East Timor into Indonesia'. Mondale noted however, 'that there are problems on how to deal with our mutual concerns regarding East Timor and how to handle [the] public relations aspect of this problem'. In this respect, Mondale advised Suharto to allow a 'private voluntary organization to be permitted to send people into East Timor ... this would have a beneficial effect on US public opinion'.

Testifying in February 1978 before the House of Representatives International Relations Committee hearing on human rights, Robert Oakley, a senior Department of State official, reframed Indonesia's invasion of East Timor as counter-insurgency, stating it was a legitimate response to 'armed groups such as FRETILIN who are employing armed forces against the government'. ${ }^{205}$ This gave US military aid a 'façade of legitimacy'. ${ }^{206}$ Ultimately, the US continued diplomatic, economic and military support to the Suharto regime following its invasion of East Timor. Coupled with the government's attempts to manipulate events in Congress and at the UN, this prevented any intervention in East Timor, from the UN or powers external to the region. As Secretary of State Cyrus Vance confirmed, 'now, insofar as speaking out on human rights issues abroad is concerned, we will speak out when we believe it is desirable to do so ... In each case we must balance a political concern for human rights against economic and security goals'. ${ }^{207}$ 


\section{Australia and the United Nations envoy}

One country notably in favour of UN General Assembly Resolution 3485 was Australia. This was despite the Fraser caretaker government implying to Suharto in advance of the East Timor invasion that it would follow an acquiescent policy, as implemented by the previous Whitlam government. For the Fraser government, 'the choice was between silent acquiescence or the encouragement of an active role by the United Nations which would keep the spotlight on the issue and would embarrass Indonesia in view of the heavy United Nations majority opposed to its actions in Timor'. ${ }^{208}$ While Australian support for UN Resolution 3485 appeared to be a sign of Australia moving away from Indonesia's East Timor policy, this was undermined by the 'ineffectiveness' of Australia's actions with respect to the UN envoy, Dr Winspeare-Guicciardi. ${ }^{209}$

As part of the UN Security Council Resolution 384, Winspeare was sent to East Timor to make an assessment of the situation there. Winspeare therefore sought access to FRETILIN controlled areas. However, Australian actions largely hindered this access. Australia began by shutting down a FRETILIN controlled radio in Darwin, citing that this was 'an illegal transmitter' and not appropriate for purpose. ${ }^{210}$ The Australian government then declined to fly the envoy to FRETILIN territory, claiming this could 'be done only when security for the aircraft and its mission was assured'. ${ }^{211}$ Australian Foreign Minister Peacock reacted to criticism that the Australian government had given in to Indonesian pressure to deny Winspeare access to East Timor, stating that 'the uncertainties of the security situation precluded the sending of any Australian aircraft into the war zone in Timor'. ${ }^{212}$ However, 'pro-FRETILIN elements in Australia claimed that a high-level source in DFA [Department of Foreign Affairs] "confirmed" that ... Peacock had agreed during his recent meetings with ... Malik in Indonesia to block Winspeare's attempt to reach FRETILIN-held areas in Timor from Australian territory'. ${ }^{213}$ This was an allegation that Peacock strongly denied, 'both publicly and privately'. ${ }^{214}$

According to the findings of the Australian Senate Foreign Affairs, Defence and Trade References Committee, the Fraser government developed a twofold policy regarding East Timor: 'Wanting to differentiate the new government's position from that of the Whitlam government, which was described as "acquiescent", on the grounds that Australia could not afford to condone Indonesia's use of force in incorporating East Timor'. ${ }^{215}$ On 4 March 1976, Australia's Foreign 
Affairs Minister Peacock called 'for a cessation of hostilities, withdrawal of Indonesian troops, [and the] implementation of a genuine act of self-determination'. ${ }^{216}$ At the same time, however, Peacock stated: 'Australia should not think of taking unilateral action against Indonesia over the East Timor issue ... it would not serve Australia's interests to embark on a collision course with Indonesia'. ${ }^{217}$ Peacock believed 'damage to Australia-Indonesia relations could be kept at a tolerable level if both sides respected each other's interests and agreed to differ over Timor'. ${ }^{218}$

However, during Fraser's visit to Jakarta in October 1976, 'the Indonesians made it clear that they would no longer accept the Peacock formula: continued Australian government criticism of the integration process would be regarded as a display of hostility toward Indonesia'. It was therefore concluded that 'Australia's interests lay in hastening, not obstructing, the spread of Indonesian control'. The meeting 'represented the end of official, albeit ambiguous, Australian opposition to the Indonesian invasion'. ${ }^{219}$ Following the meeting, the Fraser government began 'a phase of tacit support for the Indonesian policy of eliminating all East Timorese resistance'. ${ }^{220}$ Notably, neither Fraser nor Peacock reiterated the policy expressed by Peacock on 4 March, 'although they were pressed to do so on many occasions'. ${ }^{221}$ In a statement to Parliament on 20 October 1976, Peacock said 'the Government had not recognized Indonesia's incorporation of East Timor, but had to accept "certain realities". 222 Australia had to take into account 'Indonesia's view that East Timor is now part of Indonesia and that this situation is not likely to change'. ${ }^{223}$ Australia abstained from the UN Resolution on East Timor held in 1976. ${ }^{224}$ On 20 January 1978, Peacock 'announced that the Australian government had decided to 'recognize de facto' that East Timor was part of Indonesia, even though Australia remained 'critical of the means by which integration was brought about'. ${ }^{225}$ In March 1978, it was announced that Australia and Indonesia had agreed to negotiate a permanent seabed boundary south of East Timor. ${ }^{226}$ On 15 December 1978, Peacock announced that 'Australia would give de jure recognition of Indonesia's sovereignty over East Timor early in 1979'.227

\section{ASEAN capitulates to Indonesia}

With the exception of Singapore, all the ASEAN states voted against UN General Assembly Resolution 3485. Singapore's abstention, seemingly at odds with ASEAN solidarity, can arguably be explained 
by 'an inability to endorse Indonesia's conduct without appearing to prejudice its own vulnerable independence', where ASEAN solidarity 'would not be permitted to obstruct the defence of national interests' ${ }^{228}$ Lim Bian Kie, aide to Indonesia's Ali Murtopo, confirmed on 24 December that 'Suharto is 'furious' over Singapore's abstention on UNGA [UN General Assembly] Timor Resolution when all other ASEAN countries joined Indonesia in opposing it. Suharto thought he had obtained Lee's 'understanding' of Indonesian position on Timor during early Sept[ember] Bali meeting, and Singapore vote came as very cold shower'. ${ }^{229}$ Bien Kie stated that there was speculation that 'Suharto will seek reason to abort planned ASEAN summit, and it [is] certain that [Indonesia] is much less likely to be amenable to increased intra-ASEAN economic cooperation which Singapore favours'. ${ }^{230}$ Bian Kie explained 'that only rationale [Indonesia] can see for Lee's action is Brunei, where Singapore opposes Malaysia's territorial ambitions. Indonesian leadership was chagrined that GOS [Government of Singapore] apparently considered Brunei more important than relationship with Indonesia'. ${ }^{231}$

Tan Boon Seng, Singapore's Deputy Secretary of Ministry of Foreign Affairs, stated that Singapore's decision to abstain on the vote on Timor was taken 'at the highest level'. ${ }^{232}$ In explaining this decision, Tan confirmed three basic reasons why Singapore abstained. First, 'for reasons related to its own national security, the GOS was fundamentally opposed to armed intervention by any country ... GOS felt it must be consistent in supporting this principle, and did not believe it could make an exception even when it involved action by a friendly ASEAN colleague'. Second, 'the forcible takeover of Timor by Indonesian forces would provide a bad precedent and could conceivably encourage Malaysia in a similar take-over of Brunei, it could encourage at some future time possibly hostile regimes to take aggressive action against Singapore'. While Tan admitted Singapore is 'in a considerably more secure position than odd colonial remnants like Brunei or Timor ... in geographical size Singapore was smaller than both of them'. Third, Singapore felt that Indonesia 'must understand that Singapore was not prepared to go along automatically accommodating and supporting every twist and sudden turn of Indonesian diplomacy. GOS support should not be taken for granted and the sooner Indonesia realized this the better off Indonesian/Singapore relations and ASEAN would be'.

However, this position was not a sustainable one. Angered by Singapore's actions, Indonesia deliberately sought to boycott Singaporean initiatives within ASEAN. Singapore's efforts to promote 
an ASEAN Free Trade Area (AFTA) were not accepted by Indonesia, and were not adopted at the ASEAN Bali Summit in 1976. Singapore was also excluded from 'security and intelligence briefings' ${ }^{233}$ By late 1976, Singapore bowed to Indonesian pressure and joined its Southeast Asian neighbours in support of the East Timor invasion. During an unofficial visit made by Suharto to Singapore in November 1976, 'personal rapport' was re-established between the two leaders. ${ }^{234}$ As Lee later confirmed, 'I [told Suharto] Singapore ... accepted Timor as part of Indonesia, but we could not publicly endorse its invasion and occupation. He [Suharto] accepted my position that if we had voted with Indonesia we would have sent the world a wrong signal about our own security'. ${ }^{235}$ Singapore ultimately joined its Southeast Asian neighbours in helping with the dissemination of anti-FRETILIN propaganda. ${ }^{236}$

On 13 December, the Malaysian Foreign Ministry issued a statement which 'blamed Timor's troubles on Portuguese neglect and abandonment of responsibility, [and] noted that "therefore there is no legitimate authority capable of maintaining peace and order in the territory"'. ${ }^{237}$ It went on to state that the Malaysian government 'accepts the decision of the Indonesian government to allow Indonesian volunteers to enter Portuguese Timor at the invitation of the moderate groups in order to assist them to restore law and order'. ${ }^{238}$ Similarly, it was reported in the Straits Times that 'the morality of the Indonesian action is under fire from certain quarters but Jakarta simply could not stand idly by and let the leftist FRETILIN seize power unilaterally ... Jakarta could not be expected to allow the threat of insurgency at its doorstep'. ${ }^{239}$

By 1976, all ASEAN states were in support of Indonesia's policy towards East Timor. This is clearly evidenced by the Joint Communiqué released following the Ninth ASEAN Ministerial Meeting in Manila on 24-26 June 1976. Present at this meeting were all five founding members of ASEAN, who expressed the view that Indonesian actions in East Timor 'correspond[ed] with the provisions of, the United Nations Security Council Resolutions No.384 ... and No.389'. ${ }^{240}$ The meeting expressed the view that 'the solution of the East Timor question would contribute positively to the maintenance of peace and stability in the Southeast Asian region'. ${ }^{241}$ The ASEAN states also lobbied to have the discussion dropped from the Decolonization Committee, claiming it 'constituted interference in Indonesia's internal affairs'. ${ }^{242}$ 


\section{Theoretical assessment of Indonesia's invasion of East Timor (1975)}

The 1975 case is an example of ASEAN vanguard state success of resistance to sovereignty violation. The foregoing analysis has attempted to show how the uncertain regional environment of 1975 acted as a catalyst for interest convergence between Indonesia, the US and Australia with regard to Indonesia's East Timor policy. As the vanguard state, Indonesia had the most compelling interests at stake regarding East Timorese independence. East Timor's proximate location to Indonesia's border, and the vacuum that it represented, constituted a threat to Indonesia at that time. A further Indonesian interest was the desire to maximize power regionally through expansion and conquest. Indonesia actively sought external power approval for the invasion of East Timor and the integration of the territory into the archipelago. As evidence suggests, this was a dynamic process, where Indonesia actively sought great-power commitment to regional policies, which were consistent with the interests of both Indonesia and the US and Australia. Jakarta had an active and substantial role in resisting sovereignty violations from other external powers.

For these external powers, positive relations with Indonesia and the security of a key regional ally were important interests that took precedence over independence for East Timor. Clearly, there existed symmetry of interests at this time. Cooperation occurred as a response to regional threat, ${ }^{243}$ in the form of an aggressive and expansionist communism, and for the pursuit of gains, ${ }^{244}$ as evidenced by Indonesian and Australian joint oil exploration in the Timor Gap. These external powers actively supported Indonesia, providing weapons, military aid, and actively seeking to deflect diplomatic attention away from Indonesia's invasion. ${ }^{245}$ Indonesia also actively sought ASEAN state support, applying pressure where necessary, in order to show a united ASEAN front for Indonesia's East Timor policy. This was achieved, and evidenced by the Joint Communiqué released following the Ninth ASEAN Ministerial Meeting.

The Indonesian invasion of East Timor violated two principles of international law. Despite this, Indonesia was supported in its actions, regionally by the ASEAN states, and externally by the US and Australia. Although condemned by the UN and a large proportion of the international community, Indonesia was not subjected to any sovereignty violation by way of external power intervention in East Timor, which became the archipelago's 27th province in 1976. 
Analysis of the regional environment in 1975 supports the hypothesis that an increase in interest convergence between the Indonesian vanguard state and designated external actors caused the success of Indonesian resistance to sovereignty violation, from powers external to the region.

\section{Contrasting theoretical arguments}

Interestingly, Indonesia's invasion of East Timor in 1975 is largely absent from the constructivist literature on ASEAN. Indonesia's invasion represents a direct challenge to the view that a strong ASEAN norm of non-interference exists. It would also appear to contradict the view that ASEAN's norms and institutions have a largely positive impact on state behaviour. There is no mention of Indonesia's invasion of East Timor in Acharya's Constructing a Security Community in Southeast Asia, ${ }^{246}$ Whose Ideas Matter? ${ }^{247}$ or Ba's [Re]Negotiating East and Southeast Asia. ${ }^{248}$ Jürgen Haacke briefly mentions the invasion, acknowledging that 'at no point following Jakarta's intervention in East Timor in 1975 had the issue formally featured in any ASEAN meeting'. ${ }^{249}$ This, he argues, is due to Indonesian President Suharto's rejection of 'anything that smacked of interference in Indonesia's internal affairs' ${ }^{250}$ Haacke stresses that the non-interference norm is part of a set of norms, conceptualized as a diplomatic and security culture, 'that has guided the interaction of state/government leaders and senior officials representing the member states of ASEAN'. ${ }^{251}$ However, at face value, Indonesia's blatant disregard for the non-interference norm when it invaded East Timor would appear to contradict this interpretation.

One response to the relative silence on East Timor in the constructivist literature is that East Timor was not a member of ASEAN when Indonesia invaded the territory in 1975. As such, technically, Indonesia's actions do not constitute deviation from the Association's norms. This is alluded to in Haacke's discussion of intervention in East Timor, where he states that 'Indonesia had only been prepared to challenge the principles of the "ASEAN Way" indirectly, by not ascribing to them the status in relations with non-ASEAN countries that they enjoyed at the level of intramural relations'. ${ }^{252}$ However, Indonesia could have pushed for East Timor's admission into ASEAN rather than choosing to invade, consolidating an anti-communist bloc of ASEAN states at a time of regional instability. That it did not do so raises serious questions about the importance attributed to ASEAN's norms by one of ASEAN's largest and most prominent states. 
Like the constructivists, David Jones and Michael Smith pay little attention to Indonesia's invasion of East Timor in 1975. However, their reasons for doing so differ dramatically. For Jones and Smith, one of the outcomes of US retrenchment from the region was 'that it gave the ASEAN states a new latitude in policy formulation, thereby affording the insecure member states the illusion of international significance'. ${ }^{253}$ A joint declaration of sovereignty by Indonesia and Malaysia in 1971 'indicated the increasing assertiveness of ASEAN states. Indonesia in particular, as the largest member of ASEAN and aspiring to regional leadership, wished to stake out its various interests in the area'. ${ }^{254}$ However, ASEAN initiatives during this period merely revealed 'the organization's continuing ambivalence'. ${ }^{255}$ This was because the ASEAN states 'remained ultimately dependent upon the continued American security commitments'. ${ }^{256}$ In this view, Indonesia's increased regional assertiveness is subordinate to the role played by great powers, specifically the US. Similarly, Leifer argues that 'American policy towards Southeast Asia is an integral, if subordinate, aspect of a wider design in Asia in which the prime object is to ensure that the strategic balance ... is not disturbed dramatically, either in a general sense or in respect of a particular sector of the region'. ${ }^{257}$ US policy in Asia was therefore focused on 'a strong flexible military presence to help maintain the balance of power'. ${ }^{258}$

Leifer and Jones and Smith's emphasis on the role of external powers in the region provides little agency for a state such as Indonesia. However, while evidence suggests that external powers did indeed play a vital role during this period, there is also evidence to suggest that Indonesia played an active role in securing its own interests. Indeed, Suharto was astute enough to utilize external power concerns to his advantage. Leifer does state that Indonesian actions in Timor were to 'protect her interests', ${ }^{259}$ and that Indonesia's regional neighbours 'have been obliged at least privately to come to terms with Indonesia's way of securing her and their priorities'. ${ }^{260}$ However, these interests are not considered in conjunction with external power interests. Jones and Smith also minimize the role of ASEAN, which is described as a 'community of evolving ambiguity'. ${ }^{261}$ This is despite a united ASEAN being a vital component in Suharto's plan to legitimize his actions in East Timor. While the existing realist assessment of the regional environment is apt, their primary focus on external powers at the expense of regional powers leaves a gap in their analysis of Southeast Asia in the mid-1970s.

According to Lee Jones, 'Indonesia's invasion and ASEAN's support is best explained by the fear that a leftist state would emerge after 
Timor's decolonization, providing a possible base for communist "subversion". ${ }^{262}$ According to this view, Indonesia's fears 'were conditioned by the conflicts that had given rise to the Suharto regime, the social order it was attempting to defend, and the likely effects of Timorese independence on that order'. ${ }^{263}$ Jones also argues that this was 'further exacerbated by the rise of communist regimes and insurgencies across Southeast Asia, and by the worst social unrest in Indonesia since Suharto had seized power'. ${ }^{264}$ ASEAN collaborated with Jakarta because it also shared these concerns. Jones' argument therefore rests on the regional fear of communism, principally because of the effect that an independent East Timor would have on 'sociopolitical and economic order within Indonesia'. ${ }^{265}$

However, this view disregards evidence which suggests that Indonesia was well aware that there was little communist influence in East Timor. The communist factor is important, but not for the reasons Jones claims. This was a factor played upon by Suharto to receive external power acquiescence and support for his plans to invade the territory. FRETILIN is described by Jones as a 'left-wing independence movement'. ${ }^{266}$ This is despite the existence of a large number of moderates within the FRETILIN party, which was largely recognized, even by external powers, as having little communist influence. Jones discounts the possibility that Indonesia had expansionist designs with regard to East Timor. For Jones, Sukarno's aggressive foreign policy was less to do with territorial ambitions and more to do with managing social conflict. ${ }^{267}$ Similarly, in his view, Malaysian support for Indonesia's East Timor policy was due to the 'recent upsurge in its domestic communist insurgency', and fears of a 'leftist takeover of Brunei' ${ }^{268}$ Nonetheless, the fact that Suharto was apparently aware that there was little communist influence in East Timor, yet still wished to annex the territory, suggests the existence of other, more compelling explanations, with territorial gain the most convincing.

A preferred approach to those presented here is one based upon interest convergence between an ASEAN vanguard state and external powers. According to this approach, the important role played by external powers is stressed, without denying the agency of Indonesia, which clearly pursued a strategy to secure its own interests with respect to East Timor in an uncertain regional environment. Indonesia was able to use external power Cold War concerns to secure support for its East Timor policy. This increase in interest convergence caused an increase in Indonesia's ability to resist sovereignty violation from actors external to the region. 


\section{Notes}

1 United Nations General Assembly, "Question of Timor", Resolution 3485, 12 December 1975.

2 United Nations Security Council, "Resolutions on East Timor (197576)”, Resolution S/RES/389, 22 April 1976; United Nations Security Council, "Resolutions on East Timor (1975-76)", Resolution S/ RES/384, 22 December 1975.

3 United Nations General Assembly Resolution 3485, "Question of Timor."

4 Brad Simpson, "Illegally and Beautifully: The United States, the Indonesian Invasion of East Timor and the International Community, 1974-76", Cold War History 5, no. 3 (August 2005), 299.

5 Simpson, "Illegally and Beautifully", 284.

6 António Pinto Barbedo de Magalhães, East Timor Indonesian Occupation and Genocide (Porto: Oporto University, 1992), 13.

7 Ang Cheng Guan, Singapore, ASEAN and the Cambodia Conflict 19781991 (Singapore: NUS Press, 2013), 7.

8 Michael RJ Vatikiotis, Indonesian Politics under Suharto: The Rise and Fall of the New Order, 3rd ed. (London: Routledge, 1998), 2.

9 Geoffrey Robinson, If You Leave us Here, We Will Die: How Genocide was Stopped in East Timor (Princeton, NJ: Princeton University Press, 2010), 42.

10 Robinson, If You Leave us Here, We Will Die, 43.

11 Gary Hansen, "Indonesia 1975: National Resilience and Continuity of the New Order Struggle”, Asian Survey 16, no. 2 (1976), 146.

12 Barbedo de Magalhães, East Timor Indonesian Occupation and Genocide, 14.

13 Barbedo de Magalhães, East Timor Indonesian Occupation and Genocide, 5.

14 Ben Kiernan, "The Demography of Genocide in Southeast Asia: The Death Tolls in Cambodia, 1975-79, and East Timor, 1975-80", Critical Asian Studies 35, no. 4 (2003), 591.

15 Simpson, "Illegally and Beautifully", 284.

16 Simpson, "Illegally and Beautifully", 284.

17 Stephen Hoadley, "East Timor: Civil War - Causes and Consequences", Southeast Asian Affairs (1976), 417.

18 Hoadley, "East Timor: Civil War", 417.

19 José Manuel Ramos-Horta, Funu: The Unfinished Saga of East Timor (Trenton, NJ: The Red Sea Press, 1987), 65.

20 Michael Leifer, "Indonesia and the Incorporation of East Timor", The World Today 32, no. 9 (1976), 347.

21 Australia Department of Foreign Affairs and Trade, Documents on Australian Foreign Policy: Australia and the Indonesian Incorporation of Portuguese Timor, 1974-1976, ed. Wendy Way (Victoria: Melbourne University Press, 2000), 97.

22 Leifer, "Indonesia and the Incorporation of East Timor", 348. 
27 Dale Copeland, "Economic Interdependence and the Future of USChinese Relations", in International Relations Theory and the Asia-Pacific, ed. John G Ikenberry and Michael Mastanduno (New York: Columbia University Press, 2003), 323-352.

28 Ian Storey, Southeast Asia and the Rise of China (London: Routledge, 2011), 275.

29 Australia Department of Foreign Affairs and Trade, Documents on Australian Foreign Policy, 58.

30 US Department of State, Foreign Relations of the United States, 1969-1976, Vol. E-12, Documents on East and Southeast Asia, 1973-1976, ed. Bradley Lynn Coleman, David Goldman and David Nickles (Washington: United States Government Printing Office, 2011),135.

31 US Department of State, Foreign Relations of the United States, 1969-1976, 135.

32 James Cotton, East Timor, Australia and Regional Order (New York: Routledge, 2004), 38-9.

33 US Department of State, Foreign Relations of the United States, Vol. E-12, 126.

34 Ben Kiernan, Genocide and Resistance in Southeast Asia (London: Transaction, 2008), 2.

35 Kiernan, Genocide and Resistance in Southeast Asia, 110.

36 US Department of State, Foreign Relations of the United States, Vol. E-12, 297.

37 Narayanan Ganesan, "ASEAN's Relations with Major External Powers", Contemporary Southeast Asia 22, no. 2 (August 2000), 261.

38 Ramos-Horta, Funu: The Unfinished Saga of East Timor, 62-63.

39 Cotton, East Timor, Australia and Regional Order, 24.

40 Barbedo de Magalhães, East Timor Indonesian Occupation and Genocide, 10.

41 Stephen McCloskey, "Introduction: East Timor - From European to Third World Colonialism", in The East Timor Question: The Struggle for Independence from Indonesia, ed. Paul Hainsworth and Stephen McCloskey (London: Tauris, 2000), 2.

42 Cotton, East Timor, Australia and Regional Order, 9.

43 Clinton Fernandes, "Recognition as a political act: Political considerations in recognizing Indonesia's annexation of East Timor", in Territorial Separatism in Global Politics: Causes, Outcomes and Resolution, ed. Damien 
Kingsbury and Costas Laoutides (Hoboken, NJ: Taylor and Francis, 2015), 95.

44 Fernandes, "Recognition as a political act", 96.

45 Hoadley, "East Timor: Civil War", 414.

46 McCloskey, "Introduction: East Timor", 2-3.

47 Simpson, "Illegally and Beautifully", 291.

48 Hoadley, "East Timor: Civil War", 414.

49 Hoadley, "East Timor: Civil War", 414.

50 Barbedo de Magalhães, East Timor Indonesian Occupation and Genocide, 17.

51 Cotton, East Timor, Australia and Regional Order, 9.

52 James Dunn, Timor: A People Betrayed (Australia: Jacaranda, 1983), 88.

53 McCloskey, "Introduction: East Timor", 3.

54 Hoadley, "East Timor: Civil War", 415.

55 Hoadley, "East Timor: Civil War", 417.

56 Cotton, East Timor, Australia and Regional Order, 28.

57 Hoadley, "East Timor: Civil War", 417.

58 McCloskey, "Introduction: East Timor", 3.

59 Ramos-Horta, Funu: The Unfinished Saga of East Timor, 55 (Quoting figures determined by the International Committee of the Red Cross).

60 Yearbook of the United Nations 1975, Vol. 29 (New York: Office of Public Information United Nations, 1975), 857.

61 Hoadley, "East Timor: Civil War", 416.

62 McCloskey, "Introduction: East Timor", 3.

63 Hoadley, "East Timor: Civil War", 416.

64 Storey, Southeast Asia and the Rise of China, 275.

65 Hanhimäki, The Flawed Architect, 478.

66 Simpson, "Illegally and Beautifully", 283.

67 US Department of State, Foreign Relations of the United States, Vol. E-12, 13.

68 Figures acquired from Simpson, "Illegally and Beautifully", 283.

69 Hanhimäki, The Flawed Architect, 402.

70 Simpson, "Illegally and Beautifully", 289.

71 Scott Sidell, "The United States and Genocide in East Timor", Journal of Contemporary Asia 11, no. 1 (1981), 47.

72 Simpson, "Illegally and Beautifully", 283.

73 Hanhimäki, The Flawed Architect, 478.

74 Following excerpts from General Suharto and President Ford's meeting at Camp David on 5 July obtained from: U.S. Department of State, Foreign Relations of the United States, Vol. E-12, 126.

75 National Security Archive, "East Timor Revisited", in National Security Archive Briefing Book No.62, ed. William Burr and Michael L Evans, 6 December 2001, http://nsarchive.gwu.edu/NSAEBB/NSAEBB62/. 
US Department of State, Foreign Relations of the United States, Vol. E-12, 118.

77 US Department of State, Foreign Relations of the United States, 118.

78 Following excerpts from WR Smyser memorandum of 4 March 1975 obtained from: US Department of State, Foreign Relations of the United States, Vol. E-12, 120.

79 Following excerpts from WR Smyser memorandum of 4 March 1975 obtained from: US Department of State, Foreign Relations of the United States, Vol. E-12, 120.

80 US Department of State, Foreign Relations of the United States, Vol. E-12, 127.

81 US Department of State, Foreign Relations of the United States,Vol. E-12, 136.

82 US Department of State, Foreign Relations of the United States, Vol. E-12, 136.

83 Simpson, "Illegally and Beautifully", 292.

84 US Department of State, Foreign Relations of the United States, Vol. E-12, 129.

85 US Department of State, Foreign Relations of the United States, Vol. E-12, 129.

86 Following excerpts from Dr Kissinger and Adam Malik meeting on 5 September 1975 obtained from: US Department of State, Foreign Relations of the United States, Vol. E-12, 133.

87 Following excerpts from Dr Kissinger memorandum of 21 November 1975, obtained from: National Security Archive, "East Timor Revisited", Doc. 3.

88 Following excerpts from General Suharto, President Ford and Dr Kissinger meeting on 6 December 1975 obtained from: US Department of State, Foreign Relations of the United States, Vol. E-12, 141.

89 Charles Scheiner, "The United States: From Complicity to Ambiguity", in The East Timor Question, 119.

90 Paul Dibb, “The Key to South-East Asia's Security”, International Affairs 77, no. 4 (Oct 2001), 838.

91 Nancy Viviani, "Australians and the Timor Issue”, Australian Journal of International Affairs 30, no. 2 (1976), 201.

92 Peter Chalk, Australian Foreign and Defense Policy in the Wake of the 1999/2000 East Timor Intervention (Santa Monica: RAND, 2001), 1.

93 Scott Burchill, "East Timor, Australia and Indonesia", in Guns and Ballot Boxes: East Timor's Vote for Independence, ed. Damien Kingsbury (Victoria: Monash Asia Institute, 2000), 170.

94 Burchill, "East Timor, Australia and Indonesia", 170. 
95 Michael Salla, "Australian Foreign Policy and East Timor", Australian Journal of International Affairs 49, no. 2 (1995), 208.

96 Cotton, East Timor, Australia and Regional Order, 9.

97 Cotton, East Timor, Australia and Regional Order, 34.

98 Australia Department of Foreign Affairs and Trade, Documents on Australian Foreign Policy, 81-82.

99 Chalk, Australian Foreign and Defense Policy, 37.

100 Chalk, Australian Foreign and Defense Policy, 37.

101 "Agreement between the Government of the Commonwealth of Australia and the Government of the Republic of Indonesia establishing Certain Seabed Boundaries." Signed in Canberra on 18 May, 1971.

102 Australia Department of Foreign Affairs and Trade, Documents on Australian Foreign Policy, 56.

103 Salla, "Australian Foreign Policy and East Timor", 209-10.

104 Salla, "Australian Foreign Policy and East Timor", 210.

105 Salla, “Australian Foreign Policy and East Timor”, 210.

106 Parliament of the Commonwealth of Australia, East Timor: Final Report of the Senate Foreign Affairs, Defence and Trade References Committee (Canberra: Senate Printing Unit, December 2000), 121.

107 Parliament of the Commonwealth of Australia, East Timor, 119.

108 Parliament of the Commonwealth of Australia, East Timor, 120.

${ }_{109}$ Following excerpts from PM Whitlam and President Suharto meeting in September 1974 obtained from: Australia Department of Foreign Affairs and Trade, Documents on Australian Foreign Policy, 95.

110 Parliament of the Commonwealth of Australia, East Timor, 121-122.

111 Salla, "Australian Foreign Policy and East Timor", 212.

112 Parliament of the Commonwealth of Australia, East Timor, 125.

${ }^{113}$ Following excerpts from PM Whitlam and President Suharto April 1975 meeting obtained from: Australia Department of Foreign Affairs and Trade, Documents on Australian Foreign Policy, 245-247.

114 Parliament of the Commonwealth of Australia, East Timor, 129.

115 Ramos-Horta, Funu: The Unfinished Saga of East Timor, 78.

116 Parliament of the Commonwealth of Australia, East Timor, 129.

117 Jim Aubrey, "Canberra: Jakarta's Trojan Horse in East Timor", in The East Timor Question, 136.

118 Sam Pietsch, "Australian Imperialism and East Timor", Marxist Interventions 2 (2010), 9.

119 Damien Kingsbury, Power Politics and the Indonesian Military (RoutledgeCurzon: New York, 2003), 108.

${ }^{120}$ Robinson, If You Leave us Here, We Will Die, 37.

${ }^{121}$ Robinson, If You Leave us Here, We Will Die, 37.

122 Parliament of the Commonwealth of Australia, East Timor, 135. 
123 Parliament of the Commonwealth of Australia, East Timor, 147.

${ }^{124}$ Canberra Times, "Mr Whitlam links the demise of Timor with his own downfall”, Saturday 25 September 1976.

125 Canberra Times, "Mr Whitlam links the demise of Timor with his own downfall."

126 J.L. Richardson, "Problems of Australian Foreign Policy: January to June 1976”, Australian Journal of Politics and History 22 (1976), 328.

127 Parliament of the Commonwealth of Australia, East Timor, 142.

128 Salla, “Australian Foreign Policy and East Timor", 213.

129 Parliament of the Commonwealth of Australia, East Timor, 151.

${ }^{130}$ Parliament of the Commonwealth of Australia, East Timor, 151.

131 Parliament of the Commonwealth of Australia, East Timor, 151.

132 Aubrey, "Canberra: Jakarta's Trojan Horse in East Timor", 136-7.

133 Parliament of the Commonwealth of Australia, East Timor, 152.

${ }^{134}$ Following excerpts from PM Fraser message of 25 November 1975 and Suharto's response obtained from: Australia Department of Foreign Affairs and Trade, Documents on Australian Foreign Policy, 579-580.

135 Gough Whitlam, “Australia, Indonesia and Europe's Empires”, Australian Outlook 34, no. 1 (1980), 10.

136 Canberra Times, “PM ‘knew of plan’ before invasion”, 11 December 1975.

137 Canberra Times, "PM 'knew of plan' before invasion."

138 Simpson, "Illegally and Beautifully", 284.

139 Alan Dupont, "ASEAN's Response to the East Timor Crisis”, Australian Journal of International Affairs 54, no, 2 (2000), 163-4.

${ }^{140}$ Dupont, “ASEAN's Response to the East Timor Crisis", 164.

141 US Department of State, Foreign Relations of the United States Vol. E-12, 16.

${ }^{142}$ Leifer, "Indonesia and the Incorporation of East Timor", 354.

143 Sue Roff, Timor's Anschluss: Indonesian and Australian Foreign Policy in East Timor, 1974-1976 (Lampeter: Edwin Mellen Press, 1992), 21.

${ }^{144}$ Jones, ASEAN, Sovereignty and Intervention in Southeast Asia, 68.

145 Jones, ASEAN, Sovereignty and Intervention in Southeast Asia, 69.

146 Canberra Times, “ASEAN Concern”, 6 January 1976.

147 Canberra Times, "ASEAN Concern."

148 Canberra Times, "PM, Razak to discuss future of Brunei”, 14 October 1975.

149 Canberra Times, "PM, Razak to discuss future of Brunei."

150 Canberra Times, "PM, Razak to discuss future of Brunei."

151 Canberra Times, "PM, Razak to discuss future of Brunei."

152 Wikileaks Cable, "PM says no need for Malaysian troops in Timor; Brunei People's Party denounces Singapore”, The Wikileaks Public Library of US Diplomacy, 04 September 1975, 1975KUALA05302_b. https://search. wikileaks.org/plusd/cables/1975KUALA05302_b.html. 
153 Whitlam, “Australia, Indonesia and Europe’s Empires”, 11.

154 Parliament of the Commonwealth of Australia, East Timor, 137.

155 Parliament of the Commonwealth of Australia, East Timor, 137.

156 Wikileaks Cable, "Razak Visit", The Wikileaks Public Library of US Diplomacy, 23 October 1975, 1975CANBER07142_b. URL: https:// search.wikileaks.org/plusd/cables/1975CANBER07142_b.html.

157 Jones, ASEAN, Sovereignty and Intervention in Southeast Asia, 68.

158 Robert Lawless, “The Indonesian Takeover of East Timor”, Asian Survey 16, no. 10 (1976), 953.

${ }^{159}$ Lawless, "The Indonesian Takeover of East Timor", 962.

160 Wikileaks Cable, "U.S. Views on Portuguese Timor", The Wikileaks Public Library of US Diplomacy, 06 March 1975, 1975JAKART02814_b. URL: https://www.wikileaks.org/plusd/cables/1975JAKART02814_b.html.

161 Simpson, "Illegally and Beautifully", 292.

162 McCloskey, "Introduction: East Timor", 3.

163 Dunn, Timor, 277.

${ }^{164}$ East Timor: Including the Report by James Dunn, Former Australian Consul in Dili (New Zealand University Students' Association for the New Zealand Campaign for an Independent East Timor, August 1977, Wellington).

165 Sorpong Peou, Human Security in East Asia: Challenges for Collaborative Action (London: Routledge, 2008), 95.

166 Simpson, "Illegally and Beautifully", 300.

167 Peou, Human Security in East Asia, 95.

168 Kiernan, "The Demography of Genocide in Southeast Asia”, 585.

169 Kiernan, "The Demography of Genocide in Southeast Asia”, 593.

170 Dunn, Timor, 282-341.

${ }^{171}$ East Timor: Including the Report by James Dunn.

172 East Timor: Including the Report by James Dunn.

173 Parliament of the Commonwealth of Australia, East Timor, 153.

174 Ali Alatas, The Pebble in the Shoe: The Diplomatic Struggle for East Timor (Jakarta: Aksara Karunia, 2006), 19.

175 United Nations General Assembly, "Declaration on Principles of International Law Concerning Friendly Relations and Co-operation among States in Accordance with the Charter of the United Nations", Resolution 2625, 24 October 1970.

176 Yearbook of the United Nations 1975, 858.

177 Yearbook of the United Nations 1975, 858-9.

178 Yearbook of the United Nations 1975, 860.

179 Yearbook of the United Nations 1975, 861.

${ }^{180}$ Excerpts from Ramos-Horta statement obtained from: Yearbook of the United Nations 1975, 861.

181 Yearbook of the United Nations 1975, 862. 
182 Yearbook of the United Nations 1975, 862-3.

183 Yearbook of the United Nations 1976, Volume 30 (New York: Office of Public Information United Nations, 1976), 728.

184 Scheiner, "The United States: From Complicity to Ambiguity", 119.

185 Scheiner, "The United States: From Complicity to Ambiguity”, 119.

186 Simpson, "Illegally and Beautifully", 304.

187 Storey, Southeast Asia and the Rise of China, 275.

188 Storey, Southeast Asia and the Rise of China, 275.

189 Storey, Southeast Asia and the Rise of China, 275.

190 National Security Archive, "East Timor Revisited."

191 Scheiner, "The United States: From Complicity to Ambiguity”, 118.

192 Scheiner, "The United States: From Complicity to Ambiguity”, 118.

193 National Security Archive, "East Timor Revisited."

${ }^{194}$ National Security Archive, "East Timor Revisited."

195 US Department of State, Foreign Relations of the United States, Vol. E-12, 153.

196 US Department of State, Foreign Relations of the United States, Vol. E-12, 159.

197 US Department of State, Foreign Relations of the United States, Vol. E-12, 159.

198 Bradley Simpson, “Denying the 'First Right': The United States, Indonesia, and the Ranking of Human Rights by the Carter Administration, 19761980", The International History Review 31, no. 4 (2009), 805-6.

199 Simpson, "Denying the "First Right", 798.

200 National Security Archive, "A Quarter Century of US Support for Occupation", Document 3, in National Security Archive Briefing Book No.174, ed. Brad Simpson, 28 November 2005, http://nsarchive.gwu. edu/NSAEBB/NSAEBB174/\#doc23.

201 Simpson, "Denying the 'First Right", 807.

202 Simpson, "Denying the "First Right", 808.

203 Simpson, "Denying the "First Right", 809.

${ }^{204}$ Following excerpts from Walter Mondale meeting with Suharto in May 1978 obtained from: National Security Archive, “A Quarter Century of US Support for Occupation”, Doc. 29.

205 Simpson, "Denying the "First Right", 820.

206 Simpson, "Denying the 'First Right", 821.

207 Sidell, "The United States and Genocide in East Timor", 59.

208 Richardson, "Problems of Australian Foreign Policy", 333.

${ }^{209}$ Richardson, "Problems of Australian Foreign Policy", 333.

${ }^{210}$ Richardson, "Problems of Australian Foreign Policy", 333.

${ }^{211}$ Richardson, "Problems of Australian Foreign Policy", 333. 
212 Wikileaks Cable, "Timor", The Wikileaks Public Library of US Diplomacy, 28 January 1976, 1976CANBER00646_b. https://wikileaks.org/plusd/ cables/1976CANBER00646_b.html.

213 Wikileaks Cable, “Timor”, 1976CANBER00646_b.

214 Wikileaks Cable, “Timor”, 1976CANBER00646_b.

215 Parliament of the Commonwealth of Australia, East Timor, 152.

216 Parliament of the Commonwealth of Australia, East Timor, 152.

217 Canberra Times, "No lone action on Timor: Peacock", Monday 24 May 1976.

${ }^{218}$ Following summary of Fraser's visit to Jakarta in October 1976 obtained from: Parliament of the Commonwealth of Australia, East Timor, 153.

219 Salla, "Australian Foreign Policy and East Timor", 214.

220 Salla, “Australian Foreign Policy and East Timor", 215.

221 Parliament of the Commonwealth of Australia, East Timor, 154.

222 Parliament of the Commonwealth of Australia, East Timor, 154.

223 Parliament of the Commonwealth of Australia, East Timor, 155.

${ }^{224}$ Canberra Times, "UN resolution on East Timor 'lacked realism”, Friday 19 November 1976.

225 Parliament of the Commonwealth of Australia, East Timor, 155.

226 Parliament of the Commonwealth of Australia, East Timor, 156.

227 Parliament of the Commonwealth of Australia, East Timor, 157.

${ }^{228}$ Leifer, ASEAN and the Security of South-East Asia, 65, 42.

229 Wikileaks Cable, "Relations between Singapore and Indonesia", The Wikileaks Public Library of US Diplomacy, 29 December 1975 , 1975JAKART15794_b, https://search.wikileaks.org/plusd/ cables/1975JAKART15794_b.html.

${ }^{230}$ Wikileaks Cable, "Relations between Singapore and Indonesia", 1975JAKART15794_b.

231 Wikileaks Cable, "Relations between Singapore and Indonesia", 1975JAKART15794_b.

${ }^{232}$ Following statements provided by Tan Boon Seng obtained from: Wikileaks Cable, "ASEAN: Singapore/Indonesian Relations", The Wikileaks Public Library of US Diplomacy, 06 January 1976, 1976SINGAP00046_b., https:// search.wikileaks.org/plusd/cables/1976SINGAP00046_b.html.

233 Jones, ASEAN, Sovereignty and Intervention, 71.

${ }^{234}$ Lee Kuan Yew, From Third World to First, The Singapore Story: 1965-2000 (New York: HarperCollins, 2000), 270.

235 Lee, From Third World to First, 270.

236 Jones, ASEAN, Sovereignty and Intervention, 70.

237 Wikileaks Cable, "Malaysian Government Backs Indonesia on Timor", The Wikileaks Public Library of US Diplomacy, 22 December 
1975, 1975KUALA07442_b, http://search.wikileaks.org/plusd/ cables/1975KUALA07442_b.html.

238 Wikileaks Cable, "Malaysian Government Backs Indonesia on Timor", 1975KUALA07442_b.

239 Wikileaks Cable, "Malaysian Government Backs Indonesia on Timor", 1975KUALA07442_b.

240 Association of Southeast Nations, "Joint Communiqué of the Ninth ASEAN Ministerial Meeting”, Manila, 24-26 June 1976, Article 23.

${ }^{241}$ Association of Southeast Nations, "Joint Communiqué of the Ninth ASEAN Ministerial Meeting”, Manila, 24-26 June 1976, Article 23.

242 Jones, ASEAN, Sovereignty and Intervention, 71.

243 Walt, The Origins of Alliances.

${ }^{244}$ Grieco, "Realist Theory and the Problem of International Cooperation", 600-624.

245 Simpson, "Illegally and Beautifully", 300.

246 Acharya, Constructing a Security Community, 1-292.

247 Acharya, Whose Ideas Matter? 1-189.

${ }^{248} \mathrm{Ba},[$ Re]Negotiating East and Southeast Asia, 1-325.

${ }^{249}$ Haacke, ASEAN's Diplomatic and Security Culture, 197.

${ }^{250}$ Haacke, ASEAN's Diplomatic and Security Culture, 197.

${ }^{251}$ Haacke, ASEAN's Diplomatic and Security Culture, 1.

${ }^{252}$ Haacke, ASEAN's Diplomatic and Security Culture, 108.

253 Jones and Smith, ASEAN and East Asian International Relations, 49.

254 Jones and Smith, ASEAN and East Asian International Relations, 50.

255 Jones and Smith, ASEAN and East Asian International Relations, 51.

256 Jones and Smith, ASEAN and East Asian International Relations, 52.

257 Chin and Suryadinata, Michael Leifer: Selected Works, 222. Reprinted in abridged form from Michael Leifer, Conflict and Regional Order in Southeast Asia, Adelphi Paper No. 162 (London: International Institute for Strategic Studies, 1980): 13-23.

258 Chin and Suryadinata, Michael Leifer: Selected Works, 223. Reprinted from Leifer, Conflict and Regional Order in Southeast Asia.

${ }^{259}$ Leifer, "Indonesia and the Incorporation of East Timor", 352.

${ }^{260}$ Leifer, "Indonesia and the Incorporation of East Timor", 354.

${ }^{261}$ Jones and Smith, ASEAN and East Asian International Relations, 56.

${ }^{262}$ Jones, ASEAN, Sovereignty and Intervention in Southeast Asia, 59.

263 Jones, ASEAN, Sovereignty and Intervention in Southeast Asia, 59.

${ }^{264}$ Jones, ASEAN, Sovereignty and Intervention in Southeast Asia, 59.

265 Jones, ASEAN, Sovereignty and Intervention in Southeast Asia, 60.

${ }^{266}$ Jones, ASEAN, Sovereignty and Intervention in Southeast Asia, 59.

${ }^{267}$ Jones, ASEAN, Sovereignty and Intervention in Southeast Asia, 66.

${ }^{268}$ Jones, ASEAN, Sovereignty and Intervention in Southeast Asia, 68. 


\section{The Third Indochina War ${ }^{1}$}

The Third Indochina War, also referred to as the Cambodia conflict, began on 25 December 1978, when between 150,000 and 220,000 Vietnamese troops invaded and occupied neighbouring Cambodia. ${ }^{2}$ Rooted in Sino-Soviet rivalry, the conflict was intrinsically a product of the Cold War regional environment. Following Vietnam's invasion of Cambodia, Vietnamese troops also became involved in small crossborder operations in Thailand, which 'on several occasions seemed on the verge of launching a punitive attack on that country'. ${ }^{3}$ However, Thailand was never subjected to a Vietnamese invasion. As a response to Vietnamese aggression, Thailand sought closer diplomatic relations with China, weapons from Washington, and expanded its armed forces by a third.

In recognition of Thailand's role as front-line state, external powers such as China and the US, as well as regional countries belonging to ASEAN, promised to come to Thailand's aid if attacked by Vietnam. Chinese leader Deng Xiaoping succinctly expressed Chinese and Southeast Asian state fears regarding Vietnam in a meeting with US President Jimmy Carter on 29 January 1979. ${ }^{4}$ During this meeting, Deng informed Carter that 'Vietnam has become totally Soviet controlled. At least a majority of ASEAN countries assess this as an extremely grave matter ... ASEAN countries are now in the front line'. ${ }^{5}$ Evidence derived through analysis of the Third Indochina War (1978-91) will be used to support the argument that following Vietnam's invasion of Cambodia in 1978, an informal alliance developed between Thailand, China, the ASEAN states, the ousted Khmer Rouge, and to a lesser extent the US, in an effort to contain Vietnamese and Soviet influence in Southeast Asia. ${ }^{6}$ As a consequence of high interest convergence between Thailand and a designated external power, China, ASEAN was able to resist violations to the sovereignty of Thailand from a Soviet-backed Vietnam. As a front-line 
state, Thailand can be described as the vanguard state, having the most compelling interests at stake during the Cambodia conflict.

Throughout 1978 to 1991, the ASEAN states successfully lobbied the UN to deny international recognition of Vietnam's puppet regime in Cambodia. Despite this, ASEAN's diplomatic efforts were not sufficient to secure the withdrawal of Vietnam from Cambodia. Evidence will be presented to show that the end of the conflict was brought about by events outside of ASEAN's control: namely, normalization of relations between the Soviet Union and China prior to the end of the Cold War. As the vanguard state, Thailand was able to set the agenda of ASEAN to portray a united ASEAN front for Thailand's Vietnam policy, to garner great power security commitments, and to actively seek and support a great power intervention in regional affairs. While Thailand (in its capacity as the ASEAN vanguard state) clearly had an important role to play in this process, an equally important factor explaining ASEAN resistance to sovereignty violation during this time-period resides in the role played by external actors, and China in particular. As will be shown, without this external power support, it is highly likely Thailand would have resigned itself to a Vietnamese fait accompli in Cambodia.

Analysis of the Third Indochina War will begin with an assessment of the regional environment in the period 1975-1978. This period was characterized by a degree of regional uncertainty and mixed interest convergence. External power interests converged over the threat posed by Soviet expansion in the region, and a hegemonic Vietnam. However, the ASEAN states were divided. Certain ASEAN states sought a reduction in external power influence in the region. Other ASEAN states sought enhanced relations with external powers such as China, to offset the Vietnamese threat. The chapter will then consider the 1978 invasion of Cambodia by Vietnam, the China-Vietnamese Border War of 1979, and the effect of Vietnam's invasion on the ASEAN states and Thailand, with the latter emerging as the ASEAN vanguard state.

Analysis will then consider Thailand's external relations after the Vietnamese invasion, a period characterized by an increase in interest convergence between Thailand and China. It will be argued that this interest convergence caused the formation of an alliance, which was a catalyst for success of ASEAN resistance to sovereignty violation from a Soviet-backed Vietnam. An assessment of the regional environment in the period 1980 to 1991 will highlight the events that led to a withdrawal of Vietnamese troops from Cambodia. The chapter will conclude with a theoretical assessment of the chapter's findings, and 
analysis of alternative theoretical explanations for Thailand's resistance to sovereignty violation.

\section{The Southeast Asian regional environment (1975- 1978)}

In 1975, communist power was consolidated in three Southeast Asian countries: Vietnam, Laos and Cambodia. In Vietnam, the North Vietnamese communists emerged victorious from their struggle with the US-backed South. In the period 1975-78, China gradually curtailed economic and military aid to Vietnam, ${ }^{7}$ while the Soviet Union cancelled all of Hanoi's debt to Moscow, valued at US $\$ 450$ million. ${ }^{8}$ The Soviets also promised long-term aid to Vietnam in a joint communiqué on 30 October 1975, committing themselves to assisting the Vietnamese next five-year plan from 1976-80 with an aid package totalling US $\$ 2.5$ million. ${ }^{9}$ This had the effect of drawing the Vietnamese closer to the Soviet Union. Having consolidated their power, the Vietnamese attempted to secure a number of objectives. These included: a nonthreatening region; the prevention of an anticommunist front in Indochina; the elimination of US presence; and the limitation of superpower activity in the region. ${ }^{10}$ The Vietnamese communists had historically considered that an Indochinese Federation should exist in the region, to include Vietnam, Laos and Cambodia. Domination over Indochina 'required the elimination of extraneous influences in Laos and Cambodia'. ${ }^{11}$

Vietnam began by seeking a 'special relationship' with these countries. According to this relationship, governments in the two capitals would not make a major decision without clearing it with Hanoi first, and any foreign influence would be eliminated'. ${ }^{12}$ A Vietnamese delegation was sent to the Laos capital Vientiane in July 1975. Before the delegation left the capital, the Vietnamese signed with Laos a Treaty of Friendship and Cooperation. This treaty laid the basis for political coordination between the two, and for Vietnam's security role in Laos. ${ }^{13}$ Relations developed further in February 1976 following the foundation of the Laos People's Democratic Republic. Officials from Laos headed a delegation to Hanoi, the outcome of which was the 'unambiguous declaration that Laos fell under Vietnam's sphere of influence'. ${ }^{14}$ This was supplemented in July 1977 with the signing of a 25-year Treaty of Friendship.

In Cambodia, General Lon Nol had ousted the King of Cambodia, Prince Norodom Sihanouk, from power during a US-backed coup 
on 18 March $1970 .{ }^{15}$ This was shortly followed by the US invasion of Cambodia in May. Lon Nol was staunchly anti-Vietnamese, unlike Sihanouk, who sympathized with the North Vietnamese struggle against the West. Sihanouk allowed the Vietnamese communists sanctuary along the Vietnam-Cambodia border, and arms transit through the country's ports. ${ }^{16}$ Following the coup, Sihanouk sought refuge in Beijing, where the Chinese and North Vietnamese urged that he lend his name to the communist Cambodian resistance group, the Khmer Rouge. This government in exile, named The Royal Government of National Union of Kampuchea (GRUNK), existed between 1970 and 1976. The anti-Vietnamese Khmer Rouge, led by Brother Number One Pol Pot, had been fighting against the Sihanouk regime since 1967. However, it was in the regime's best interests to cooperate with Sihanouk and the North Vietnamese after the Prince's exile. The revolutionary faction gained legitimacy in Cambodia by using the Prince's name, attracting support from the peasantry who were devoted to Sihanouk. ${ }^{17}$ This helped the Khmer Rouge gain control over Cambodia. The alliance also benefited the North Vietnamese, who saw the government in exile as a resistance to US domination and as a means of maintaining Vietcong sanctuaries within Cambodia.

Between 1973 and 1975, the Khmer Rouge aimed a number of offensives at the Cambodian capital, Phnom Penh. A February 1973 attempt failed after the US launched a massive B-52 bombing raid around the capital. ${ }^{18}$ An offensive in the early months of 1974 also failed, although the Khmer Rouge 'noose around the city was considerably tightened'. ${ }^{19}$ The Khmer Rouge final offensive for Cambodia began in January 1975, following the rejection of further military aid to Cambodia from the US government. ${ }^{20}$ By April, they had closed in on Phnom Penh. At this time Lon Nol left the country, and the US made the decision to evacuate. By 17 April, the Khmer Rouge had taken control of the state, renaming it Democratic Kampuchea.

\section{The Soviet and Vietnamese threat}

Both China and the US perceived Vietnam, backed by the Soviet Union, to be a regional threat. As the Vietnam War developed, China increasingly voiced its disapproval of North Vietnamese collaboration with the Soviet Union, which enhanced Chinese fears of a larger Soviet encirclement policy directed against China. ${ }^{21}$ The feeling amongst the 
Chinese was that, 'if Vietnam was not against Moscow, it was against China'. ${ }^{22}$ Vietnamese reliance on the Soviet Union, and an increase in Soviet-Vietnamese cooperation, led to a further deterioration in both the Sino-Soviet and Sino-Vietnamese relationships. ${ }^{23}$ From as early as 1969, China began to reassess its policy towards the US. By engaging in Sino-American rapprochement, China could use the US to balance the Soviet threat. At the same time, a newly-elected President Nixon was beginning a similar reassessment of the SinoAmerican relationship. US rapprochement with China would engage the latter in balancing the Soviet Union, and would help to reduce US presence in Vietnam. ${ }^{24}$

From 1973 onwards, it became apparent to the US that China viewed Moscow and Hanoi as key regional threats. US Secretary of State, Henry Kissinger, confirmed that China 'wants four separate Indochinese states and not one state dominated by Hanoi. Because they could not be sure that this single state would not be under the influence of Moscow'. ${ }^{25}$ In 1975, Deng Xiaoping, Vice Premier of the State Council of the People's Republic of China (PRC), informed Kissinger of China's fears that 'the Soviet Union will increase its influence in Vietnam and Laos'. ${ }^{26}$ Similarly, in 1978, Foreign Minister Huang Hua informed US National Security Advisor Dr Zbigniew Brzezinski that 'the countries that are subjected to the Soviet threat must make serious efforts to resist the expansion of the Soviet Union'. ${ }^{27}$ China was especially concerned about Soviet influence over Vietnam. Foreign Minister Hua informed Secretary of State Cyrus Vance in 1978 that Vietnam's 'objective is regional hegemony, and it has hired itself out to the Soviet Union, while the Soviet Union has exploited the ambitions of Vietnam to realize its aggression' ${ }^{28}$

The US had similar concerns, which were heightened following US retrenchment from Southeast Asia following the conclusion of the Vietnam War. In a meeting between Kissinger and Vice Premier Deng in 1974, Kissinger stated that the US 'will not permit a strategic gain for Soviet power. We will attempt to reduce Soviet power where we can'. ${ }^{29}$ The US was similarly aware of Soviet influence over Vietnam, and the latter's desire for regional hegemony. Dr Brzezinski informed Foreign Minister Hua in 1977 that the US is 'opposed to the creation of an Indochinese federation dominated by Vietnam. We realize what is behind it'. ${ }^{30}$ US Secretary of Defence Harold Brown surmised that, 'to the extent our opening to China reduces the chances of SinoSoviet détente, we gain enormously ... it is very important to stabilize our relationship with China and to avoid the situation where the Chinese are allied with the Soviets against us'. ${ }^{31}$ 
Clearly, in the period 1975 to 1978 , Chinese and US interests increasingly converged with respect to the Soviet and Vietnamese threat. Both China and the US believed that the Soviet Union had expansionist aims for Southeast Asia. Both states also recognized Vietnam's potential hegemonic ambitions, which they believed were supported by the Soviet Union. For both China and the US, improved relations were seen as a vital component in balancing the Soviet Union, blocking its expansion further east and tying down a portion of the Soviet military effort.

\section{Intra-ASEAN interest divergence}

While threats posed by the Soviet Union and Vietnam led to increased interest convergence between China and the US, the ASEAN states were less able to reach a common threat consensus. This was despite Vietnamese communist victory and US regional retrenchment having a major impact on the region. The non-communist ASEAN states, which in 1975 included Indonesia, Malaysia, the Philippines, Singapore and Thailand had, to varying degrees, all relied upon the US security umbrella during the Vietnam War. Many of the ASEAN states provided diplomatic or military support to the US in its effort against the North Vietnamese. Most notable contributions involved Thailand, which assisted the US bombardment of North Vietnam and sent ground combat forces to support South Vietnam, ${ }^{32}$ and the Philippines, which maintained major US military bases on the island of Luzon. ${ }^{33}$ US retrenchment was therefore met with much regional consternation. This was especially notable in Thailand and the Philippines, which had provided most help to the US during the war. Regional states voiced their concerns during a visit made by Mr Habib to Southeast Asia in June 1975. In a memorandum from Kissinger to US President Gerald Ford summarizing the trip, Kissinger confirmed that for the Southeast Asian states 'there is a uniform desire that the US play a supporting - and deterrent - role in the region'. ${ }^{34}$ Indonesian Foreign Minister Adam Malik expressed a similar view to Kissinger in 1976, stressing that the ASEAN states 'regard as especially important that the US remain interested in Southeast Asia'. ${ }^{35}$

Following the Paris Peace negotiations, there was a move among the ASEAN states to establish diplomatic relations with North Vietnam. Malaysia established relations with Hanoi on 30 March 1973. ${ }^{36}$ This was followed by Singapore on 1 August $1973 .{ }^{37}$ Indonesia, which had established diplomatic relations with Hanoi in 1964, sent an 
ambassador to North Vietnam in early $1973 .{ }^{38}$ While Thailand and the Philippines also made an attempt to establish diplomatic relations at this time, their collaboration with the US during the Vietnam War hampered these efforts. Thailand extended an invitation to the North Vietnamese to send an observer to the ASEAN Ministerial Meeting to be held in April 1973. Hanoi rejected this invitation due to Thai involvement in the Vietnam War. ASEAN extended a similar invitation in 1974. However, Hanoi argued that ASEAN was too heavily influenced by the West, and the Association was 'venomously flayed as a de facto military alliance'. ${ }^{39}$

The suddenness with which the Vietnam War ended caused considerable alarm among the ASEAN states. However, the period is notable for the disparate ASEAN state responses to North Vietnamese victory. As one commentator noted, 'much of the initiative towards accommodation with the emerging realities of the power structure in the region was effectively in the hands of individual member states rather than in ASEAN as a regional grouping' ${ }^{40}$ The lack of ASEAN consensus was reflected in the Joint Communiqué issued at the end of the 8th ASEAN Ministerial Meeting on 13-15 May 1975, which made no mention of recent developments in Indochina. ${ }^{41}$ Of the ASEAN states, most alarm was felt in Thailand, 'the country closest to the epicentre of political and military turmoil'. ${ }^{42}$ In a January 1975 meeting the Thai Foreign Minister, Charunphan Isarangkun $\mathrm{Na}$ Ayuthaya, stated that the Thai government was aware that if both Cambodia and South Vietnam collapsed to North Vietnam, the next major threat 'first and foremost is Thailand' ${ }^{43}$ In a June 1975 Secretary of State Staff meeting, Mr Habib confirmed that 'the Thai are desperate to find some means of protecting themselves. So they will try every diplomatic channel ... at the same time, they will be pleading, I am sure, with the ASEAN group to give them the support of the regional organisation'. ${ }^{44}$

By November 1975, a Thai strategy to counter the Vietnamese threat was already beginning to materialize. In a meeting between Secretary Kissinger and the Thai Foreign Minister Chatchai Chunawan, Kissinger informed Chatchai that the US would like Cambodia 'to be independent as a counterweight to North Vietnam ... we would prefer to have Laos and Cambodia aligned with China rather than with North Vietnam. We would try to encourage this if that is what you want'. ${ }^{45}$ Chatchai replied: 'yes, we would like you to do that ... the Chinese are 100 percent in support of Cambodia's being friends with Thailand'. Chatchai informed Kissinger that he had 'asked the Chinese to take over in Laos'. Kissinger stated that the US 'would support 
this. You should also tell the Cambodians that we will be friends with them. They are murderous thugs, but we won't let that stand in our way'. Confirming this strategy in a separate meeting between Chatchai and New Zealand officials, Chatchai stated that he wanted Cambodia and Laos 'strong enough to be buffers between Thailand and [the] Vietnamese' ${ }^{46}$ Similarly, in a meeting with Japanese officials in Tokyo in October 1975, Chatchai made it clear that the situation in Indochina was 'very dangerous' for Thailand, and that Hanoi was the major threat. ${ }^{47}$ Japanese officials believed Chatchai implied a 'linked PRC, Cambodia and Thailand in [a] quasi-alliance'. ${ }^{48}$

The remaining ASEAN states exhibited varying levels of concern, with Vietnamese communist victory bringing 'the least response from the country furthest away, Indonesia'. ${ }^{49}$ Indonesian Minister of Defence General Maraden Panggabean stated in April 1975 that 'naturally [the] prospect of communist takeover in Indochina creates a very real concern in Indonesia'. ${ }^{50}$ However, 'Indonesians hoped ... and were inclined to believe, that communists in Indochina were as much nationalists as communists. If this was [the] case, relations with them over longer term would be possible'. ${ }^{51}$ The Indonesian government also believed that this was a view shared by other ASEAN states. Indonesian Director-General of Political Affairs Djajadiningrat stated that the ASEAN states would welcome membership of a communist Vietnam in ASEAN, so long as the 'Vietnamese regime is not expansionist and is willing to be [a] good neighbour'. ${ }^{52}$

The Malaysian government recognized the PRG [Provisional Revolutionary Government of the Republic of South Vietnam] following the fall of Saigon, stressing that good relations could exist with the Vietnamese communist government, whilst 'privately fear[ing] the results of Indochina's fall' ${ }^{53}$ Taking a position similar to that of Indonesia, acting Malaysian Prime Minister, Ghafar Baba, stated the Malaysian hope that 'both the new governments in Cambodia and South Vietnam would cooperate with ASEAN countries'. ${ }^{54}$ Singapore's Prime Minister, Lee Kuan Yew, took an approach closer to that of Thailand. Lee informed Kissinger in a meeting in May 1975 that his 'immediate reaction [to the fall of Saigon] is one of astonishment and alarm at the rapidity with which the situation fell apart'. ${ }^{55}$ Kissinger informed Lee that 'this year Hanoi will do more than take Laos. They are fully occupied with absorbing what they have already conquered. They are very careful planners, and they will step up in Thailand and Malaysia next year'. Lee agreed, stating that the North Vietnamese 'have American weapons now. It sends chills down my spine. My worst fears have come true ... I must be careful so as 
not to scare the Malays and the Thais that the situation is hopeless ... Laos and Cambodia are gone'.

According to Lee, the North Vietnamese 'need only take the corner of Thailand, and they could for example take over the Mekong hydroelectric scheme. They would then have the entire Mekong delta. That is one step they may risk. Then they would have a basis for becoming an industrial power.' In an April 1975 meeting between Lee and a Thai delegation in Bangkok, that included the Thai Prime Minister Khukrit Pramot and Foreign Minister Chatchai, Lee informed Chatchai that he sees Thailand as potentially 'the next domino' in Southeast Asia. ${ }^{56}$ It was therefore vital that they maintain a US presence in order to resist communist incursions. ${ }^{57}$ Of all the ASEAN states, the Philippines remained the most detached from the crisis. Geographically isolated and home to US bases, the Philippines President Marcos remained 'firm in his expressions that the USPhilippine security relationship is essential to his country'. ${ }^{58}$

\section{Vietnam and the Soviets seek enhanced Southeast Asia relations}

Meanwhile, seeking to enhance regional security and secure economic aid, a reunified Vietnam began to make diplomatic overtures towards the ASEAN states. These first began in 1976, when Hanoi announced a policy of establishing 'relations of friendship and cooperation' with Southeast Asian countries. ${ }^{59}$ Relations were to be based on a mutual respect for independence, good neighbour policies and the prevention of regional countries being used as a base for external power aggression. However, Vietnam would only deal with regional states individually, believing ASEAN to be a 'product of the US imperialist policy of intervention and aggression'. ${ }^{60}$ Vietnam was forced to reassess this position in mid-1978, at a time of increased Sino-Vietnamese conflict. In competition with China for the 'hearts and minds' of ASEAN, Vietnam announced its willingness to deal with ASEAN in June 1978. ${ }^{61}$ In September 1978, Vietnam's Prime Minister, Pham Van Dong, visited the capitals of ASEAN, dispensing assurances of nonintervention. ${ }^{62}$ Prime Minister Pham was particularly concerned with trying to obtain a friendship treaty with Thailand. Pham 'dropped Hanoi's demand for the return of all planes and vessels used by refugees fleeing South Vietnam in 1975, pledged that Vietnam would not support the Thai insurgency, signed agreements in repatriation of refugees who had fled Vietnam in the 1940s and on commercial and economic cooperation'. ${ }^{63}$ Vietnam's Deputy Foreign Minister, Phan 
Hien, also 'recognized ASEAN as a "genuine regional organization for economic cooperation"". ${ }^{64}$ All of the ASEAN states, despite varying policies towards Vietnam, decided against rushing into a formal agreement with Vietnam at that time. ${ }^{65}$

Following the end of the Vietnam War, the Soviet Union revived the notion of a collective security system in Asia, which it had been attempting to garner support for since as early as 1969. The Soviet aim was to take advantage of US disengagement, to increase a regional presence, and to assert influence against the Chinese. ${ }^{66}$ However, the proposal never received regional support. This was largely due to regional states recognizing the proposal as an antiChina move, and not wishing to provoke Beijing. ${ }^{67}$ The Soviet Union also sought to reconcile ASEAN and Vietnam in the hope that 'the ASEAN countries might become more receptive to influence from the communist states in Indochina'. ${ }^{68}$ The Soviets particularly sought to capitalize on ASEAN efforts for a Zone of Peace, Freedom and Neutrality (ZOPFAN). ZOPFAN was identified as a regional goal by the ASEAN states at the 1971 Kuala Lumpur Declaration, and was in part a response to the intrusive Soviet collective security scheme. ${ }^{69}$ In this declaration, the ASEAN countries stated their intent to keep Southeast Asia free from external interference by outside powers. The Soviet Union seized upon ZOPFAN 'as an indication that the region was moving away from total reliance upon the West'. ${ }^{70}$ While some ASEAN states did move to enhance diplomatic relations with the Soviet Union, this did not result in any formal alliances. Kissinger confirmed that the regional states 'are all suspicious' with regard to the Soviet Union, 'they place their trust in the US deterrent and the SinoSoviet conflict as the basic checks on soviet expansionism in Asia'. ${ }^{71}$

Thailand was willing to tolerate an increased regional role for the Soviet Union following the end of the Vietnam War. However, this was only as a means to maintain some regional US presence, and to demonstrate to Vietnam that Thailand was not completely dependent on the US or China. ${ }^{72}$ Soviet diplomatic relations with the Philippines was restored in June 1976. However, this was recognized by the Soviets as of secondary importance to relations with China, which had been restored in June 1975. While the Soviet Union hoped that shared perceptions of a threatening China might make Indonesia amenable to their influence, 'Indonesian desire for the removal of the great powers from the region conflict[ed] with Soviet intentions'. ${ }^{73}$ Malaysia hoped that the Soviet Union might play a mediating role between Vietnam and the ASEAN states. However, Malaysian desire for a reduction in great power influence in the region meant that this was the extent to 
which Soviet involvement was encouraged. Taking a similar approach to that of Thailand, Singapore engaged with the Soviet Union to maintain a regional balance of power, hoping Soviet engagement would act as a 'device to ensure a continuing Western presence in the region'. ${ }^{74}$

\section{ASEAN-China relations}

During the 1949 to 1970 period, the states of Southeast Asia viewed China as having regional hegemonic intentions. Chinese-backed communist insurgencies in Southeast Asia had threatened domestic political structures and regional peace and stability. Indonesia suspected Beijing's involvement in a 1965 communist conspiracy, which killed the large majority of Indonesia's top military command. ${ }^{75}$ Chinese support for communist guerillas in Thailand and Malaysia also continued late into the 1970s. ${ }^{76}$ To balance this threat, the ASEAN states sought an enhanced US regional presence. However, this situation changed with US-Chinese rapprochement, US retrenchment following the Vietnam War, and an increase in Sino-Soviet and Sino-Vietnamese hostilities. At this time, the majority of the ASEAN states sought to normalize relations with China. Malaysia was first to establish relations with China in May 1974, followed by the Philippines in June 1975 and Thailand in July 1975. By late 1975, China had started to reduce its support for communist insurgencies in Southeast Asia. One US official noted that 'Peking's public views ... have been muted of late. Particularly since the establishment of relations with Bangkok and Manila'. ${ }^{77}$ This was seen as an effort to 'placate ASEAN governments' sensitivity concerning public PRC support for the insurgents'. ${ }^{78}$ Singapore, although stating that it would not establish relations with China before Indonesia, still sought to improve its relations with Beijing. ${ }^{79}$ Lee informed US Secretary of Defence, James Schlesinger, in May 1975 that the North Vietnamese could move all the way to Singapore, and that Singaporeans 'don't believe the US would make a move, but we do believe the PRC would, and that is protecting us' ${ }^{80}$

This left Indonesia 'practically isolated' from the rest of ASEAN. ${ }^{81}$ Indonesia traditionally viewed China as an, 'aggressive and expansionist power,' and was displeased with Beijing's attempt to 'woo' ASEAN countries, and with the "current "panicky rush" of ASEAN countries to Beijing' ${ }^{82}$ Deng Xiaoping told US President Ford in December 1975 that, 'Indonesia does not have good relations with us, but we are in no hurry ... as far as China is concerned, we are willing to improve 
relations with Indonesia, but we have patience' ${ }^{83}$ Ford informed Deng that he will 'speak very forcefully to them concerning this effort' when he is next in Indonesia. ${ }^{84}$

Of the ASEAN states, Thailand was most keen to develop diplomatic relations with China. In a May 1975 meeting Lee Kuan Yew informed Kissinger that Thailand would "come to terms with China ... China is their insurance agent' ${ }^{85}$ Thai Foreign Minister Charunphan confirmed this approach in a 1975 meeting with US Senators Thurmond and Scott, stating that 'the Thai had been approaching China confidentially to lower the level of these [subversive] activities [in Thailand] since before President Nixon went to Peking. ${ }^{86}$ US ambassador to Thailand, Charles Whitehouse, informed US National Security Advisor, Brent Scowcroft, that 'the Thai saw Vietnam as the real threat and China as a rather benevolent power even if some Thai also recognized that this benevolence stemmed from China's self-interest' ${ }^{87}$ Enhanced relations resulting from the Vietnamese threat had an immediate impact on bilateral trade between Thailand and China, which increased from US $\$ 4.7$ million in 1974 to US\$136.4 million in $1976 . .^{88}$

\section{China encourages enhanced Thai-Cambodian relations}

China also mediated an agreement to establish relations between Thailand and Cambodia in $1975 .{ }^{89}$ This was a vital component in China's Vietnamese containment policy. Historically, relations between Thailand and Cambodia had been characterized as one of 'unending conflicts'.${ }^{90}$ Cambodia viewed Thailand as an, 'oppressive neighbour' which sought to envelop Khmer territory. ${ }^{91}$ Despite this history of poor relations, Thailand recognized that Cambodia could be used as a 'fence state' to protect itself from Vietnamese attack. ${ }^{92}$ Thailand could also be useful to Cambodia. Democratic Kampuchea had already begun a diplomatic offensive with regard to the ASEAN states in 1975, recognizing 'diplomatic support of ASEAN as an important factor given an impending conflagration'. ${ }^{93}$ Thai and Cambodian officials met twice in 1975, at China's behest. At Thailand's insistence, the ASEAN states 'collectively and promptly recognized the new Phnom Penh government' on 18 April 1975. ${ }^{94}$ In October 1975, Cambodian Foreign Minister, Ieng Sary, visited Bangkok, where it was agreed that Thailand and Cambodia would establish diplomatic relations. ${ }^{95}$

In an official scheduled visit by Chinese Vice-Premier Deng to Thailand, Malaysia and Singapore in early November 1978, Deng sought support for China's Vietnam policy, and 'impressed upon his 
foreign hosts that China would use force against Vietnamese aggression if Vietnam attacked Cambodia'. ${ }^{96}$ Evidence therefore suggests that by 1978 , at least two ASEAN states had adopted a clear policy that sought to engage with external powers to face the Vietnamese threat. The remaining ASEAN states believed that accommodation with the Vietnamese may be possible, and that engagement with external powers compromized a ZOPFAN in Southeast Asia. These different strategies prevented the formation of a united ASEAN front. Instead, the regional states largely pursued policies in defence of their own national interests.

\section{Vietnam's invasion of Cambodia - a catalyst for convergence}

The Khmer people had long been wary of Vietnamese regional ambitions. According to Prince Sihanouk, 'the Khmer people have serious reasons not to like the Vietnamese. Our neighbours in the east have, in effect, in the course of the centuries, "swallowed" territories which had always belonged to Cambodia'. ${ }^{97}$ In relations with Vietnam, Sihanouk stated that he 'always adopted a realist attitude ... it was a very dangerous neighbour, to be handled with care' ${ }^{98}$ Sihanouk concluded that the US would eventually retrench from the Southeast Asian region, thus making accommodation with North Vietnam inevitable. Unlike Sihanouk, the Khmer Rouge did not wish to accommodate the Vietnamese due to Vietnam's history of intervention in Cambodia, which had seen Khmer territory ceded to the Vietnamese. The opinion within the Khmer resistance government was that Vietnam was their 'acute enemy'. ${ }^{99}$ Clashes between Khmer fighters and Vietnamese troops were reported throughout the mid1970s. In an attempt to gain total control of Cambodia, the Pol Pot group 'stepped up a campaign to denigrate Sihanouk' ${ }^{100}$ and sought to 'blunt Vietnamese expansion, [and] pre-empt Hanoi's effort to exert influence over Phnom Penh'. ${ }^{101}$ As Sihanouk's role in Cambodia was increasingly marginalized, clashes between the Khmers and the Vietnamese communists escalated. ${ }^{102}$

The North Vietnamese tolerated these clashes in order to maintain sanctuaries along the Cambodia border. Similarly, while Cambodia wanted to avoid the emergence of a strong Vietnam in Indochina, the balance of forces within the Communist Party of Kampuchea (CPK) was not ready for open confrontation with the North Vietnamese. ${ }^{103}$ In 1976, Pol Pot argued that the building of communism in Democratic 
Kampuchea had to be hurried, in order to confront the Vietnamese with greater strength. ${ }^{104}$ According to a research study prepared by the CIA, the Khmer Rouge communists showed themselves 'to be the most extreme of the world's totalitarian regimes'. ${ }^{105}$ The regime adopted 'unorthodox economic practices', that included the total mobilization of the Cambodian people, abolition of private ownership and the departure from a money economy. ${ }^{106}$ The Cambodian urban population underwent forced resettlement into rural areas, which was justified 'as a means to create a huge permanent labour force in the countryside'. ${ }^{107}$ In its desire to implement a communist system quickly, it is believed 21 to 26 percent of the country's population were killed. ${ }^{108}$ Even those within the regime were subject to large-scale killings and routine purges. ${ }^{109}$

The Khmer Rouge began to assume a greater role in Chinese foreign policy between November 1973 and April 1974. China was concerned with increased Soviet aid to the Vietnamese, and saw enhanced relations with Cambodia as a means to balance a Sovietaligned Vietnam. ${ }^{110}$ Enhanced relations between China and Cambodia were realized in a May 1974 agreement, which provided the Khmer Rouge with free military equipment and supplies. ${ }^{111}$ In April 1975, Cambodia negotiated a Chinese military aid package of 13,300 tons of weapons. ${ }^{112}$ By mid-September, 'China was prepared to extend to Cambodia a total of US $\$ 1$ billion in interest-free economic and military aid, including an immediate $\$ 20$ million gift'. ${ }^{113}$ This was reportedly 'the biggest aid ever given to any one country by China'. ${ }^{114}$

China anointed the Sino-Khmer alliance on 28 September 1977. ${ }^{115}$ However, Chinese leaders still sought to exercise a 'moderating influence' on the Khmer Rouge, and to point the regime 'in the direction of a more traditional realpolitik foreign policy'. ${ }^{116}$ According to a November 1978 US Interagency Intelligence Memorandum, China may have been 'unhappy with some of the policies of the present Khmer regime', but it still considered 'an independent Kampuchea allied with Peking an essential buffer against the expansion of Vietnamese, and by extension Soviet, influence in the area' ${ }^{117}$ China hoped 'to thwart Vietnamese ambitions by providing strong support for Kampuchea'. In its bid to prevent Vietnamese regional expansion, China became 'the principal source of military and economic aid to Kampuchea'.

With Chinese aid and firm domestic control, Pol Pot began to eliminate all Vietnamese influence in Cambodia from 1977. Cambodia openly declared a cessation in diplomatic relations with Vietnam on 31 December 1977. ${ }^{118}$ This was construed by the Vietnamese as 'the 
creation of a "bridgehead of aggression" on behalf of the Chinese'. ${ }^{119}$ The Vietnamese feared that Pol Pot was consolidating the Khmer Rouge position internationally, and gathering Southeast Asian and Western sympathizers. ${ }^{120}$ Seeking to put a halt to this process, the Vietnamese decided to remove Pol Pot as leader of the Kampuchean communist party. A US Intelligence Assessment reported that 'Hanoi seems determined to bring a more malleable regime to power in Phnom Penh, while China shows no sign of willingness to soften its support of the current Cambodian leadership'. ${ }^{121}$

\section{Vietnam's invasion and its after effects}

Following the Vietnam War, Vietnam's domestic situation was in disarray. This was characterized by 'acute food shortages, a steadily sagging economy, rampant official mismanagement, and cadre misbehaviour'. ${ }^{122}$ Unable to receive aid from countries such as the US and China, Vietnam was driven further into the arms of the Soviet Union. Vietnam joined the Comecon, a Moscow based economic arrangement, in August 1978. On 3 November 1978, it signed a treaty of Friendship and Cooperation with Moscow, which resulted in a massive shipment of Soviet military hardware to Vietnam. ${ }^{123}$ A closer relationship with the Soviet Union provided economic and military aid, as well as security assurances against an aggressive China. However, the increase in Soviet-Vietnamese relations led to a further decrease in Sino-Vietnamese relations. ${ }^{124}$ China viewed the treaty as a direct threat, believing it represented 'another step in the Soviet effort to establish a collective security system in the region, ultimately directed against China' ${ }^{125}$

China responded with a diplomatic effort to strengthen its regional relationships. ${ }^{126}$ The most important of these was enhanced relations with Thailand, which China believed could be used in a Vietnamese containment strategy. ${ }^{127}$ Two days after Vietnam signed the treaty of friendship with the Soviet Union, Deng travelled to Bangkok to seek more formal security cooperation. ${ }^{128}$ Deng assured the Thai Prime Minister, General Kriangsak Chamanan, that Beijing would end its support for the Communist Party of Thailand (CPT) and would punish Hanoi for its hegemonic behaviour. ${ }^{129} \mathrm{He}$ also stated that China would help enhance Thai security against the Vietnamese threat. While Kriangsak did not immediately agree to a formal alliance, the meeting set the groundwork for future enhanced relations.

With Soviet economic and security assurances, Vietnam now felt in a position to take action against an increasingly aggressive Cambodia. A 
hostile Cambodia posed a serious threat to Vietnamese security. Apart from Cambodia's close physical proximity to Vietnam, Cambodia's relationship with China allowed an external power a regional presence in Indochina. It was vital for Vietnam that Cambodia be prevented 'from becoming springboards for attacks on its territory or havens for organizing insurgencies'. ${ }^{130}$ Vietnamese attempts to remove Pol Pot began during 1977, with a series of shallow military incursions that sought to trigger a military coup in Phnom Penh, or to spark a civil war. ${ }^{131}$ When these attempts failed, the Vietnamese attempted to create a liberation movement within Cambodia in mid-1978. While successful, the Vietnamese came to the decision that the strategy was too protracted. As such, in December 1978, the Vietnamese decided on a third strategy, 'the highly visible big unit war'. ${ }^{132}$ The first phase of the assault commenced on 25 December 1978, when between 150,000 and 220,000 Vietnamese troops invaded neighbouring Cambodia. ${ }^{133}$ On 7 January 1979, Pol Pot was driven from Phnom Penh by Vietnamese troops, supported by some 20,000 dissident Cambodians. ${ }^{134}$ Elements of the Khmer Rouge survived, including approximately 20-40,000 troops, which withdrew to the jungle. ${ }^{135} \mathrm{On}$ 8 January, a Vietnamese puppet government, titled the Kampuchean United Front for National Salvation (FUNSK), was installed, headed by Heng Samrin, a former Khmer Rouge defector who fled to Vietnam during the regime purges.

On 31 December 1978 and 3 January 1979, Deputy Prime Minister in charge of Foreign Affairs of Democratic Kampuchea, Ieng Sary, charged Vietnam 'with intensifying acts of aggression against his country, including ground and air attacks, pillaging, burning and killing' ${ }^{136}$ Sary requested an urgent meeting of the UN Security Council to condemn Vietnam's attack. ${ }^{137}$ On 4 January, a Vietnamese representative transmitted two December FUNSK declarations to the UN, which charged that 'the regime of Prime Minister Pol Pot and Foreign Minister Ieng Sary of Democratic Kampuchea had usurped power, transformed the revolutionary forces into mercenaries for the Chinese authorities, and threatened the Kampuchean people with extermination'. ${ }^{138}$ A Vietnamese representative transmitted further documents to the UN on 8 January concerning the liberation of Phnom Penh, stating that 'any meeting of the Security Council to hear the representative of the Pol Pot regime would constitute intervention in the internal affairs of the Kampuchean people'.

The UN Security Council met from 11 to 15 January at the request of Democratic Kampuchea, and from 23 to 28 February at the request of Norway, Portugal, the United Kingdom and the US. At each 
meeting, a draft resolution calling for cessation in hostilities and a demand for strict adherence to non-interference was rejected, owing to the negative vote of the USSR [Union of Soviet Socialist Republics]. The Soviet Union objected to these resolutions, as it considered FUNSK 'to be the genuine and sole representative of the Kampuchean people, and that the situation in that country was an internal matter. ${ }^{139}$ The Council extended an invitation to the delegation of Democratic Kampuchea, and a representative reiterated that 'his country was the victim of large-scale aggression by Viet Nam (sic), supported by the USSR'. In a letter to the UN on 20 February 1979, Vietnam transmitted the text of a Treaty of Peace, Friendship and Cooperation between the Socialist Republic of Vietnam and the People's Republic of Kampuchea, signed at Phnom Penh on 18 February by Heng Samrin and Pham Van Dong. ${ }^{140}$ This effectively consolidated Vietnam's influence in Cambodia and hegemonic position in Indochina.

\section{China's plan to teach Vietnam a lesson}

Vietnam's invasion of Cambodia drew an immediate Chinese response. In a letter to the UN dated 7 January 1979, China charged that Vietnam 'had invaded Democratic Kampuchea, was occupying a large part of the country and, with USSR support, intended to annex Kampuchea by force and set up an "IndoChinese Federation" under its control' ${ }^{141}$ In a meeting between President Carter and Premier Deng on 29 January 1979, Deng argued that 'the Vietnamese now are extremely arrogant. They now claim to be even the third most powerful military nation in the world, after the United States and the Soviet Union ... we consider it necessary to put a restraint on the wild ambitions of the Vietnamese and to give them an appropriate limited lesson'. ${ }^{142}$ With regard to potential Soviet reprisals, Deng believed that the Soviet Union 'did not have adequate forces to conduct any large military operations against China immediately'. ${ }^{143}$ He expressed the belief that 'if our action in the South is quickly completed, they won't have time to react ... we need your [the US] moral support in the international field'. ${ }^{144}$

However, Carter was not quick to give this support. He informed Deng that 'this is a serious issue. Not only do you face a military threat from the North, but also a change in international attitude ... it could result in escalation of violence and a change in the world posture from being against Vietnam to partial support for Vietnam.' 
Carter followed this with an oral presentation to Deng on 30 January, confirming the US belief that a punitive strike against Vietnam 'would be a serious mistake ... the United States could not support such action, and I strongly urge you not to approve it'. Deng was unmoved by Carter's presentation, insisting that China 'are forced to make the decision to take necessary self-defense operations against Vietnam. This operation will be restricted and limited in scope ... it may play a certain role to check the ambitions of Vietnam and will benefit peace and stability of this region'. Having informed the US of China's intentions, Deng then set out to woo the ASEAN countries, embarking on a nine-day tour through Thailand, Malaysia and Singapore, with the task of assuring 'these countries of China's benevolent role as guardian of regional security and to enlist their support in the confrontation with Vietnam'. ${ }^{145}$

China's military action against Vietnam came approximately two weeks after Deng's visit to Washington. US Secretary of Defence, Harold Brown, believed this was 'clearly Deng's intent ... to use security relations with us [the US] as a means of constraining the USSR'. ${ }^{146}$ On 10 February 1979, Vietnam transmitted an urgent message to the UN from its Deputy Prime Minister and Minister for Foreign Affairs, which 'charged that China had recently intensified armed activities at the Vietnamese frontier in preparation for war'. ${ }^{147}$ On 17 February, the Chinese government issued a statement arguing that 'because Vietnamese authorities had ignored China's warnings and repeatedly encroached on Chinese territory and attacked Chinese frontier guards and inhabitants, China had been forced to counterattack'. ${ }^{148}$ On 18 February, a representative from the Soviet Union charged 'China with aggression against Viet Nam, blatantly flouting international law and exposing the essence of Peking's hegemonic policy in Southeast Asia'. ${ }^{149}$

The Sino-Vietnamese border war was fought in three stages, beginning on 17 February, and ending with a complete withdrawal on 16 March. ${ }^{150}$ It involved 400,000 Chinese troops, ${ }^{151}$ and was the largest People's Liberation Army (PLA) military operation undertaken since the Korean War. ${ }^{152}$ The attack caught Hanoi off-guard, forcing them to resist the Chinese advance whilst requesting immediate aid from Moscow. The Chinese claimed the war to be a victory, with more than a dozen border cities captured and 57,000 Vietnamese soldiers wounded or killed. ${ }^{153}$ The Vietnamese claimed they lost several cities, but only after killing and wounding 42,000 Chinese troops. ${ }^{154}$ However, the PLA were willing to absorb heavy losses, as long as the conflict achieved its strategic goals. The PLA believed 
these goals had been achieved, and that the war had succeeded in 'exposing Moscow's inability or unwillingness to back Vietnam'. ${ }^{155}$ While the use of force against Vietnam had been condemned by the US, albeit ambiguously, and raised the suspicions of regional states such as Indonesia and Malaysia, ultimately there was very little backlash, regionally or internationally.

\section{Emergence of the ASEAN vanguard state}

ASEAN responded to Vietnam's invasion of Cambodia with a diplomatic effort at the UN. On 9 January, Indonesia issued a statement from its Minister for Foreign Affairs, as Chairman of the ASEAN Standing Committee, expressing 'grave concern' over the escalation of the conflict between Cambodia and Vietnam. ${ }^{156}$ The convening of a UN Security Council meeting was requested to discuss the situation in Indochina. On 12 January, Indonesia issued a joint statement of a special meeting of the ASEAN Foreign Ministers held in Bangkok, in which the Ministers, 'deplored the armed intervention in Kampuchea, affirmed the right of the Kampuchean people to determine their future by themselves; [and] called for the immediate withdrawal of foreign forces from Kampuchean territory'. ${ }^{157}$ An ASEAN Foreign Ministers joint statement was also released on 13 January in relation to Indochinese refugees displaced due to conflict in Cambodia. The ASEAN ministers 'expressed their grave concern over the increasing influx of these persons into ASEAN countries ... the influx is encountering severe economic, social, political and security problems particularly in the countries bearing the main brunt of the influx, such as Thailand and Malaysia'. ${ }^{158}$

ASEAN submitted two further letters to the UN in 1979. On 20 February, Indonesia issued a statement by the Chairman of ASEAN's Standing Committee, 'appealing for a cessation of hostilities and withdrawal of all foreign forces from all areas of conflict in IndoChina'. ${ }^{159}$ This statement became the basis for a draft UN resolution, sponsored by the five ASEAN countries, to be considered at a Security Council meeting on 16 March. By this text, the Council urgently called upon all parties to "cease all hostilities forthwith, withdraw their forces to their own countries and settle their disputes by peaceful means'. On 17 August 1979, the ASEAN states sent a letter to the UN, requesting inclusion of an item on 'The situation in Kampuchea' in the agenda of the General Assembly's 34th (1979) session. The General Committee considered this request on 19 December, where Thailand 
argued that 'the armed conflict in Kampuchea was creating a refugee problem and thereby imposing immense strain on neighbouring countries'. China supported inclusion of the item, 'charging Viet Nam with aggression against Democratic Kampuchea, which, it said, posed a serious threat to the security and stability of Southeast Asia'.

The General Committee decided, by 19 votes to 5, with one abstention, to recommend that the General Assembly include the item in its agenda. On 14 November, the General Assembly adopted resolution $34 / 22$ by which it 'called for the immediate withdrawal of foreign forces from Kampuchea'. The resolution was adopted by a vote of 91 to 21, with 29 abstentions. The ASEAN Ministers decided to explore the possibility of a settlement to the Cambodia conflict, by dispatching the Malaysian Foreign Minister, Tengku Ahmad Rithauddeen, to Hanoi as an ASEAN representative. ${ }^{160}$ Although the Vietnamese would not accept Rithauddeen as an ASEAN envoy, he did visit the Vietnamese capital as Foreign Minister of Malaysia from 9-11 January 1980. During this meeting, the Vietnamese 'refused to discuss the presence of their forces in Kampuchea'. ${ }^{161}$

\section{ASEAN's internal debate}

Despite the joint ASEAN statements released following Vietnam's invasion of Cambodia, the conflict did not immediately create cohesion within ASEAN. There still remained disagreement over the major source of threat, and what should be done about it. There was, however, a general feeling that Vietnam's attempt to placate the ASEAN states in 1978 had been a 'duplicitous stratagem', and a 'manoeuvre to soften them as part of Vietnam's preparations to invade Cambodia'. ${ }^{162}$ Moscow's funding of the campaign also 'hurt its image'163 in the region, with states of the opinion that Moscow 'had attempted to gain illegitimate entry into the region'. ${ }^{164}$ The alliance between Moscow and Hanoi also badly damaged ASEAN confidence in Vietnamese claims to be a nonaligned nation. ${ }^{165}$ Despite this general feeling, certain ASEAN states continued to feel some sympathy for the Vietnamese. Indonesia and the Philippines indicated that they 'did not consider that Vietnam posed any threat to ASEAN'. ${ }^{166}$ Indonesia remained particularly concerned about the regional role of China, with both Indonesia and Malaysia preferring to pursue a ZOPFAN in Southeast Asia, for fears that they were becoming trapped in a wider Sino-Soviet dispute. According to this view, enhanced Soviet regional influence might lead to a situation where 'China was using ASEAN for 
its own political objectives, and ASEAN was implementing Chinese policies'. ${ }^{167}$ These states were also concerned that taking a hard stance against Vietnam might bring about either 'a debilitated Vietnam subject to China's dominance or a debilitated Vietnam bound in a permanent client relationship to the Soviet Union which would in turn reinforce the Thai-Chinese relationship'. ${ }^{168}$

Even Thailand wished to maintain some façade of neutrality. The Thai Prime Minister, General Kriangsak Chamanan, stated his government's formal position of neutrality in a visit to Moscow in 1979, hoping to gain assurances against an aggressive Vietnam, and to placate Moscow as to Thailand's relationship with China. ${ }^{169}$ However, this was merely pretence to seek great power assurances. Both Thailand and Singapore viewed Chinese aid 'as a bellwether for stability'. ${ }^{170}$ The lack of regional cohesion meant that Thailand felt dissatisfied with the level of support offered by the ASEAN states. Thailand showed this dissatisfaction through local news reports, stating 'concern in the Foreign Ministry that other countries had not shown they were prepared to fully support Thailand in the event of an attack on it by Vietnam'. ${ }^{171}$ The Thai government wanted 'its regional partners [to] stand up and be counted in a collective demonstration of ASEAN solidarity'. ${ }^{172}$

Two events can be credited with enhancing institutional cohesion in 1979 and early 1980. The first was the influx of refugees into Southeast Asia from Indochina. The problem of Cambodian refugees in Thailand was the topic of several communications to the UN Secretary General during June and August 1979. ${ }^{173}$ In a letter to the UN dated 23 October, Thailand stated that 100,000 Cambodians had entered Thailand as a result of fighting. ${ }^{174}$ Many in the ASEAN states believed that Vietnam was sending "out the "boat people" to destabilize the countries of the southeast where they land, and that this is done with Moscow's encouragement'. ${ }^{175}$ The second event was a series of armed incursions by Vietnamese troops against camps in Thailand. Representatives of Thailand alleged violations of Thai territory during October and November 1979. Thailand claimed that on 14 and 21 October, 1 and 23 November and 27 December, mortar rounds fired from Cambodian territory had landed in Thai territory, and troop intrusions and shellings had killed and wounded Thai civilians, thus violating Thai neutrality. ${ }^{176}$ Vietnam responded with statements transmitted on 28 November and 21 December 1979, which "charged Thailand with colluding with the remnants of the Pol Pot-Ieng Sary regime and creating tension on the Thai-Kampuchean frontier by tolerating the use of Thai territory for supply centres and sanctuaries for combatants'. ${ }^{177}$ 
The influx of refugees into Southeast Asia, coupled with Vietnamese incursions into Thailand, had the effect of 'obliging wavering members of ASEAN to close ranks once more in support of the Association's front-line state'. ${ }^{178}$ From that point, 'ASEAN became more explicit in its challenge to Vietnam', and the 'political fortunes of ASEAN were made hostage to solidarity with Thailand'. ${ }^{179}$ By May 1979, the Malaysian Prime Minister had made a successful visit to China, indicating a shift away from Vietnam. ${ }^{180}$ Malaysia also cancelled aid and technological cooperation agreements with Vietnam, tripled the size of its air force and doubled the size of its army. ${ }^{181}$ The Philippines announced a $\$ 200$ million increase in its military budget, and Indonesia ordered 60 army battalions to be brought to full strength. ${ }^{182}$ From 1979, 'military planning in Indonesia, Malaysia, Thailand, and Singapore ... shifted from internal, counter-insurgency warfare to preparation for conventional warfare'. ${ }^{183}$

The presence of the Soviet Pacific Fleet in the South China Sea and Indian Ocean encouraged Malaysia to agree to the basing of Australian P3-C reconnaissance aircraft. ${ }^{184}$ Singapore went so far as to propose military cooperation with external powers and to call upon ASEAN to aid Khmer Rouge guerrillas in their fight against the Vietnamese. ${ }^{185}$ As the front-line state, Thailand obtained $\$ 30$ million credit for arms purchases and military aid from the US, with additions bringing the total aid package to $\$ 400$ million. ${ }^{186}$ Thailand also increased the army by 20 battalions, a one-third increase. ${ }^{187}$ From 1979 onwards, the ASEAN states were forced to seek additional military assistance from the US. In 1982, Indonesia, Philippines and Singapore sent military delegations to Washington to discuss arms purchases. In 1984, the Thai air force group sought to purchase F-16 fighter-bombers. ${ }^{188}$ Reliance on external power security guarantees meant that ASEAN's aspiration for a ZOPFAN in Southeast Asia had 'given way to a more real-politik [underlining in text] security formulation'. ${ }^{189}$

\section{ASEAN's internal debate: a summary}

Evidence suggests that by the end of 1979, Thailand had assumed the role of ASEAN vanguard state. ASEAN support was an important component in Thailand's anti-Vietnam policy. Thailand made it clear to the ASEAN states that it expected total commitment in the face of Vietnamese aggression, in addition to enhanced regional relations with extra-regional powers. While this policy was unpopular with certain ASEAN states, the influx of refugees into Southeast Asia, 
coupled with Vietnamese incursions into Thailand, had the effect of increasing solidarity for Thailand, as the front-line ASEAN state with the most compelling interests at stake in the conflict. Although these events did not erase lingering concerns regarding the role of external powers in the region, they did have the effect of creating a united ASEAN front, which was used to great diplomatic effect at the UN.

\section{ASEAN vanguard state - external power interest convergence}

On 13 January 1979, several senior staff members of the PLA flew to meet with Thai premier Kriangsak. The following day 'was spent in long sessions discussing the modalities of Sino-Thai cooperation in the Cambodian war ... it was at that secret meeting between Chinese and Thai military leaders that a foundation of de facto Sino-Thai alliance was laid'. ${ }^{190}$ China was in desperate need of Thai support, as noted in a US telegram from the Embassy in China, in which it stated that 'Beijing's strategy is heavily reliant on Thai cooperation ... if the Vietnamese spill over into Thailand, the risk of a major PRC military strike against Vietnam will be commensurately greater'. ${ }^{191}$ As part of the Sino-Thai alliance, Kriangsak agreed to allow the Chinese use of Thai territory to support the Khmer guerrillas. ${ }^{192}$ This arrangement began as soon as cooperation between the two was formalized. With Thailand and the Khmer Rouge, China had created a united front against Hanoi expansionism.

China and the ASEAN states also encouraged a continued American regional presence. In a conversation between President Carter and Vice Premier Deng on 29 January 1979, Carter confirmed that the US is 'encouraging the ASEAN countries to stand united against Vietnam, and we are increasing military aid to Thailand'. ${ }^{193}$ Deng agreed with this approach, stating that, 'at least a majority of ASEAN countries assesses this [as] an extremely grave matter ... ASEAN countries are now in the front line'. Throughout 1979, China continually stressed the importance of Thailand in the fight against the Vietnamese. In July 1979, National Security Council Staff members Nicholas Platt and Richard Holbrooke visited Beijing to meet Foreign Minister Huang Hua. On his return, Platt reported to US National Security Advisor Brzezinski that Hua 'stressed the threat to Thailand, where seven Vietnamese divisions are poised on the border. If Thailand goes, "the rest of ASEAN will fall like dominoes"”. ${ }^{94}$ 
In an August 1979 meeting between US Vice President Walter Mondale and Chinese Vice-Premier Deng, Mondale stated that in Indochina, we share the same objectives: to create an independent Kampuchea that is not threatening to its neighbors, to prevent Laos from falling further under Vietnam and Soviet sway, to protect Thailand and other ASEAN states, and to show Vietnam that its increasing dependence upon Moscow will hurt badly over time and should be abandoned.' 195 Mondale stated that the US 'understand Thai and other ASEAN concern ... the US stands ready to work closely with China and with ASEAN in making progress to this end'. Deng was adamant that the most important 'conditions for a political settlement must be the genuine independence of Kampuchea and the withdrawal of Vietnamese troops from the country'. Deng insisted that 'any political settlement that departs from these two preconditions is in fact aiding the Vietnamese and aiding the Russians'.

The Sino-Thai alliance did not mean that Bangkok and Beijing always shared the same view. Unlike China, 'it was not ASEAN's objective to humiliate Vietnam'. ${ }^{196}$ Vietnam was only perceived as a threat due to its invasion of Cambodia. Singapore stated its desire for 'a strong, independent and prosperous Vietnam, rather than a Vietnam which was a satellite of China'. ${ }^{197}$ This difference in SinoASEAN viewpoints provided Thailand with an additional, diplomatic role, whereby Thailand could 'serve as a link and facilitator between China and Southeast Asia'. ${ }^{198}$ In an October 1980 visit to Beijing, Thai Prime Minister Prem Tinsulanond secured Chinese 'willingness to consider ASEAN's proposal to create a coalition resistance government that would include non-communist forces as well as the Khmer Rouge'. ${ }^{199}$ Thailand also sought to alleviate tensions between the PRC and ASEAN at a UN international conference in July 1981. Thailand persuaded ASEAN countries to move closer to the Chinese position on the need for the Khmer Rouge, as well as patching up misunderstandings, and alleviating lingering concerns regarding China's true intentions. ${ }^{200}$

\section{ASEAN vanguard state resistance to sovereignty violation}

In an August 1979 meeting between US Vice President Walter Mondale and Chinese Vice-Premier Deng, Mondale informed Deng that the US have 'placed major emphasis on the closest consultation with ASEAN countries including improved security assistance to Thailand, more modern planes, more economic assistance and 
military assistance'. ${ }^{201}$ Deng agreed with Mondale's support for the ASEAN states, stating that 'ASEAN countries particularly Thailand, Malaysia, and the Philippines have expressed their apprehension that the Vietnamese may attack them, and I told them in the event of an attack against the ASEAN countries, we will stand on their side. And I told them that we mean what we say'. Thailand was at the forefront of this support. In a meeting between President Carter and Premier Hua in July 1980, Carter informed Hua that the US 'had expedited shipment by air to Thailand of some weapons they had ordered'. ${ }^{202}$ Hua stated that China was making "every effort to assist the Thais, including shipments of "natural resources". China was also "taking pressure off Thailand by tying down 29 SRV [Soviet Republic of Vietnam] infantry divisions along the Sino-Vietnamese border'. As an added element of security, Hua had informed 'the Thais that the PRC would "side with them" if Vietnam made another large-scale attack into Thailand'.

Security cooperation was clearly in the interests of both Thailand and China following Vietnam's invasion of Cambodia. The informal security alliance that developed between Thailand, ASEAN, China, the US and the ousted Khmer Rouge was a counter-encirclement strategy that sought to contain the Soviet and Vietnamese threat. ${ }^{203}$ Although China received permission from Thailand to aid the Khmer Rouge through Thai territory, Thailand received security guarantees that greatly enhanced its ability to resist Vietnamese aggression. ${ }^{204}$ Thailand was now in a position to 'report Vietnamese shellings or attacks on the Thai border and expect that within six hours the Chinese troops on the Sino-Vietnamese border would repay the Vietnamese in kind'. ${ }^{205}$

While it is unclear whether Vietnam would have invaded Thailand, thus violating Thai sovereignty, there existed the belief, both regionally and among the external powers, that Thailand could be the next domino to fall. If this did occur, the rest of Southeast Asia was under increased threat. China, the US, Malaysia and Indonesia all promised to assist Thailand in case of a Vietnamese attack. ${ }^{206}$ While ASEAN could provide 'collective political defence,' it could not provide 'countervailing power'. ${ }^{207}$ As such, Thai responses to the Vietnamese invasion of Cambodia 'involved large power diplomacy'. ${ }^{208}$ As an ASEAN vanguard state, Thailand played the important and necessary function of actively seeking and supporting great power intervention in regional affairs, which was consistent with the interests of both Thailand and the external actor in question, China. By doing so, Thailand, as an ASEAN vanguard state, had an active and substantial role in resisting sovereignty violations from a Soviet-backed Vietnam. 


\section{The regional environment 1980-1991}

Without the capabilities to provide a military response to Vietnam's invasion of Cambodia, ASEAN resorted to a diplomatic initiative at the UN. It was vital that ASEAN portray a united front, to prevent international recognition of the Heng Samrin puppet regime in Phnom Penh. This diplomatic initiative began in 1979, and continued for the duration of the conflict, with the ASEAN states also lobbying the UN repeatedly regarding refugee flows from Cambodia, and Vietnamese incursions into Thai territory. The credentials of the delegation of Democratic Kampuchea also became a topic for debate at the UN, which were examined by the Credentials Committee on 22 September 1980. ${ }^{209}$ Singapore took the position that 'if Democratic Kampuchea were to lose its seat in the United Nations, it would be tantamount to saying that it is permissible for a powerful military state to invade its weaker neighbour, to overthrow its government and to impose a puppet regime on it'. ${ }^{210}$ China, Singapore and the US stated that 'Democratic Kampuchea was a Member State of the United Nations and its Government was the sole legal representative of Kampuchea; therefore its credentials were in order'. ${ }^{211}$ However, 'both Singapore and the United States indicated that they continued to deplore that Government's human rights record'. ${ }^{212}$

This had been a point of contention among the US, China and the ASEAN states. Deng argued that 'in deciding to form a united front we cannot exclude Pol Pot because Democratic Kampuchea is practically the only force of resistance now in Kampuchea' ${ }^{213}$ However, the United States claimed that 'if Pol Pot is the sole focal point of resistance to Heng Samrin, the situation is likely to get worse'. ${ }^{214}$ In July 1979, the US announced a policy of recognizing neither the Pol Pot nor the Heng Samrin governments. ${ }^{215}$ The Assembly voted to reject any amendment to the credentials of Democratic Kampuchea by a vote of 35 in favour to 74 against, with 32 abstentions. ${ }^{216}$ Democratic Kampuchea said that 'rejection of the amendment had helped to prevent Viet Nam from legalizing its invasion of Kampuchea'. ${ }^{217}$ In October 1980, the General Assembly adopted resolution 35/6, by which it decided to convene in 1981 'an international conference on Kampuchea to seek a political settlement'. ${ }^{218}$

The International Conference on Kampuchea was held in New York on 13-17 July 1981, with a mandate to seek a comprehensive political settlement of the Cambodian problem. ${ }^{219}$ At the conference, 79 member states participated. A proposal by Singapore that 'three political groups be invited to participate without vote was approved with respect to the 
Khmer People's National Liberation Front [KPNLF] and the National United Front for an Independent, Neutral, Peaceful and Co-operative Cambodia'. The Conference 'referred to its Bureau the question of the participation of the People's Revolutionary Party of Kampuchea'. The KPNLF was a political front formed by Son Sann, a former Prime Minister of Cambodia, who opposed the Heng Samrin regime. Prince Sihanouk formed the National United Front for an Independent Neutral Peaceful and Co-operative Cambodia with the encouragement of the ASEAN states, which hoped to provide a more credible alternative for Cambodia than that offered by the ousted Khmer Rouge.

The International Conference on Kampuchea adopted a Declaration setting out elements for negotiation and resolution of the conflict, which included 'withdrawal of all foreign forces from Kampuchea; restoration and preservation of its independence, sovereignty and territorial integrity; and a commitment by all states to noninterference in its internal affairs'. The Declaration was approved on 21 October 1981 by the General Assembly, which adopted resolution 36/5 by a recorded vote of 100 to 25 , with 19 abstentions. This resolution reiterated that 'withdrawal of all foreign forces and the Kampuchean people's right to determine their own destiny were principal components of any resolution of the problem'. The Assembly also noted a joint statement issued by Singapore on 4 September, in which 'Prince Norodom Sihanouk, Son Sann and Khieu Samphan [a leading figure within the Khmer Rouge] expressed the desire to form a coalition Government of Democratic Kampuchea'.

\section{Stalemate at the United Nations}

In a communiqué on the Kampuchea situation issued on 18 June 1981, the ASEAN Foreign Ministers 'proposed a political settlement including United Nations peacekeeping forces, foreign troop withdrawal and the disarming of all Khmer factions' ${ }^{220}$ Following elections held by the Vietnamese regime in Cambodia, the Philippines Foreign Minister, as Chairman of the ASEAN Standing Committee, transmitted a statement on 25 March 'by which the ASEAN members denounced the elections as an attempt by the Heng Samrin regime to legitimize itself'. ${ }^{221}$ Thailand also continued to make submissions to the UN Secretary General complaining of incursions from Cambodian territory by Vietnamese-Heng Samrin forces. This included over 80 separate violations between June 1980 and January 1981,222 something vigorously denied by Vietnam. 
On 22 June 1982, Prince Sihanouk, Khieu Samphan, and Son Sann signed the Declaration of the Formation of the Coalition Government of Democratic Kampuchea (CGDK) at Kuala Lumpur. Under the coalition, these became President, Vice President in charge of Foreign Affairs and Prime Minister, respectively. ${ }^{223}$ Vietnam responded to the Coalition Government by calling it a 'farce that had been in production by China and the United States for over a year, and it regretted support of that farce by the Association of Southeast Asian Nations'. ${ }^{224}$ Despite the formation of the CGDK, 'virtually all Chinese supplies were channelled only to the Khmer Rouge'. ${ }^{225}$ China blamed 'the Sihanouk forces' lack of organization and the KPNLF's factionalism as explanations for China's refusal of military assistance to them' ${ }^{226}$

Having reached a stalemate, the Cambodian crisis remained unresolved for the majority of the 1980s. The General Assembly continued to call for a lasting solution to the conflict, ${ }^{227}$ and the ASEAN Foreign Ministers continued to release joint statements appealing to 'efforts towards a just solution of the Kampuchea situation so as to restore Kampuchea's status as an independent and sovereign state'. ${ }^{228}$ The ASEAN states also continued to call upon Vietnam to engage in talks with the Coalition Government of Democratic Kampuchea. In a joint statement issued 8 July 1985 by the ASEAN Foreign Ministers, it was reported that the 'Coalition Government of Democratic Kampuchea had informed them that it was ready to enter into exploratory indirect or "proximity" talks with Viet Nam ... to discuss the basic elements of a comprehensive, political settlement'. ${ }^{229}$ In a 9 October 1985 letter from the Chairman of the ASEAN Standing Committee, it was reported that 'Viet Nam had not responded positively to ASEAN's proposal'. ${ }^{230}$

\section{Indonesia's diplomatic initiatives: the Kuantan principle}

Despite committing itself to providing a united ASEAN response to the invasion of Cambodia, Indonesia believed 'that a compromize should be reached between ASEAN and Vietnam', and this 'was reflected in Indonesia's unilateral diplomatic attempts to soften Vietnam's position'. ${ }^{231}$ Within Jakarta, there existed some resentment regarding the 'shift in the political centre of gravity of the Association from Jakarta to Bangkok ... [which] had the effect of diminishing Indonesia's assumed position of corporate leadership'. ${ }^{232}$ For Jakarta, Thailand's Vietnam policy 'and its implication for ASEAN ... had been described as "the Thai tail that wags the ASEAN dog". ${ }^{233}$ Still 
motivated by fear of China, Indonesia and Malaysia continued to seek a diplomatic settlement with Vietnam that deviated from China's 'bleed Vietnam white' strategy. ${ }^{234}$ These attempts were articulated in March 1980 in the Kuantan principle, which was largely a reiteration of the 1971 ZOPFAN declaration. ${ }^{235}$ In an effort to reduce great power influence in the region, the principle proposed that 'Vietnam would agree to cut its Soviet ties ... if Thailand delinked from China and the Khmer Rouge'. ${ }^{236}$ The statement also 'pointedly took cognizance of Vietnam's security interests in Indochina'. ${ }^{237}$

In doing so, Indonesia and Malaysia confirmed that they were prepared to accept Vietnamese hegemony in Cambodia, in return for reduced tensions at the Thai-Cambodian border and a reduction in great power meddling in the region. ${ }^{238}$ Despite Indonesian and Malaysian efforts, the Kuantan principle was never implemented. This was largely due to a failure to gain either Chinese or Vietnamese endorsement for the proposal. ${ }^{239}$ The declaration also 'proved to be totally unacceptable to Bangkok'. ${ }^{240}$ As the state most threatened by Vietnam, Thailand would 'quietly sabotage any initiative that it perceived as against Thai interest'. ${ }^{241}$ During a tour of ASEAN capitals, General Prem Tinsulanond, 'went out of his way in both Kuala Lumpur and Jakarta to indicate hostility to the Kuantan message'. ${ }^{242}$ ASEAN concessions were not acceptable to Thailand or Singapore, which 'publicly stood by the earlier ASEAN resolution calling for a complete withdrawal of Vietnamese forces'. ${ }^{243}$ Ultimately, President Suharto 'was not prepared to test the cohesion of the Association for the sake of a divisive joint formulation whose practical application was uncertain'. 244

\section{Jakarta Informal Meeting (JIM)}

Despite the failure of the Kuantan principle, Indonesia maintained its efforts to engage with Vietnam diplomatically. Recognizing this, the ASEAN states designated Jakarta the role 'official ASEAN interlocutor' with Vietnam. ${ }^{245}$ Indonesia made two unpublicized trips to Hanoi in 1980 and 1982 to find a compromize to the Cambodian conflict. A third, official, trip came on 13-15 February $1984 .{ }^{246}$ From 25-28 July 1988, Indonesia invited representatives from the four Cambodian parties, Prince Sihanouk from the National United Front for an Independent Neutral Peaceful and Co-operative Cambodia, Son Sann from the KPNLF, Khieu Samphan from the Party of Democratic Kampuchea, and authorities in Phnom Penh, headed by Hun Sen - 
as well as the Lao People's Democratic Republic, Vietnam and six members of ASEAN to meet for discussions at a cocktail party in Jakarta, later titled the Jakarta Informal Meeting (JIM). One positive outcome from the JIM was that all parties to the Cambodian crisis met for the first time, 'even though their respective positions remained incompatible'. ${ }^{247}$ For Indonesia, the process was 'an opportunity to take a higher international profile'. ${ }^{248}$ However, this did not mean Suharto had deviated from ASEAN's collective approach to the conflict. Suharto recognized that 'the unity and solidarity of ASEAN is more important than the maintenance of good bilateral relations with Vietnam'. ${ }^{249}$ A second Jakarta Informal Meeting (JIM II) took place from 19-21 February 1989. Singapore noted 'a more substantive convergence of interests amongst the three - Indonesia, Vietnam and the PRK - to work out a "regional solution" which could resist SinoSoviet pressure' ${ }^{250}$

Thailand, on the other hand, 'adopted a generally low-key role at JIM II which they were not supportive of in the first place'. ${ }^{251}$ Singapore also noted that 'the JIM process reflected the Indonesian assessment that Indonesia and Vietnam, as the two major powers in the region, should shape regional order and not let the external powers dominate'. ${ }^{252}$ However, the meeting revealed disagreements on certain aspects of the settlement of the Cambodia conflict, particularly 'the establishment of a provisional quadripartite authority of national reconciliation under the leadership of Prince Sihanouk'. ${ }^{253}$ Despite failing to provide a diplomatic solution to the Cambodian problem, and despite continued difference among the ASEAN member states, Suharto continued to maintain public solidarity with ASEAN on the issue of Cambodia. ${ }^{254}$

\section{The end of the Third Indochina War}

On 5 April 1989, Vietnam announced the decision to withdraw all of its troops from Cambodia by the end of September. ${ }^{255}$ Vietnam announced that this had been completed between 21 to 26 September 1989. ${ }^{256}$ These steps towards conciliation coincided with a change in Soviet leadership. Mikhail Gorbachev became leader of the Soviet Union in March 1990. Faced with increased domestic and economic problems, Gorbachev realized that 'ameliorating the Sino-Soviet conflict and disengaging China from the Western security system was a far more important objective than having good relations with Vietnam and significant influence in Indochina'. ${ }^{257}$ China placed conditions on 
normalization of relations with the Soviet Union, one of which was that Moscow cease support of Vietnam in Cambodia. ${ }^{258}$

A subsequent reduction in Soviet economic and military aid left Vietnam effectively abandoned. Military aid to Vietnam was 'almost exclusively' Soviet. ${ }^{259}$ By the 1980 s the Soviet Union was providing Vietnam with 97 percent of its military hardware. This was a marked increase from 1975, when the Soviet Union was only providing 75 percent. ${ }^{260}$ Vietnam was unable to support its wartime economic and military policy in Cambodia without Soviet aid. Faced with a change in the status quo, Vietnam had little option but to capitulate to China. Beijing offered 'reduced border tension and lower defence costs in return for Vietnamese withdrawal from Cambodia'. ${ }^{261}$ As Vietnam began to withdraw all of its troops from Cambodia, China eased tensions along the Sino-Vietnamese border and began to improve diplomatic relations between the two. In August 1990, the four Cambodian parties accepted a framework for a comprehensive political settlement, drawn up by the five permanent members of the UN Security Council. ${ }^{262}$ The Cambodian parties agreed to form a Supreme National Council (SNC) that would represent Cambodia at the United Nations. ${ }^{263}$ With the basis for a Cambodian settlement arranged, and with an end to the Cold War in sight, the Third Indochina War came to an official end on 23 October 1991.

\section{Theoretical assessment of the Third Indochina War (1978-1991)}

After many years of seeking a diplomatic solution to the Cambodian conflict, the ASEAN states ultimately had little say in its conclusion. This was because the conflict was essentially a product of great power Cold War rivalry. However, ASEAN and its supporters maintain the view that the Association played a key role in preventing the Vietnamese regime in Cambodia from receiving international recognition. Undoubtedly, Thailand, and by extension ASEAN, played an important role in the conflict. They did so in order to secure Thailand's own interests, which were to prevent sovereignty violations from a Soviet-backed Vietnam. Thailand therefore had an active and substantial role in resisting sovereignty violations from other external powers. But an equally important factor is the role played by China, and to a lesser extent, the US. Had it not been for the informal alliance that developed, it is highly likely that Thailand would have resigned itself to Vietnamese domination in Indochina. ASEAN alone did not 
have the capabilities to reverse Vietnam's Cambodia policy, or to stand against Vietnam if it had sought to expand into Thailand. This suggests that convergence of both ASEAN vanguard state and external actor interests are necessary to secure ASEAN vanguard state resistance to sovereignty violation.

The case of the Third Indochina War can be understood in terms of a realist theoretical logic. The Soviet Union and Vietnam posed a clear threat to the external powers and to the ASEAN states. They responded to this threat by engaging in external and internal balancing strategies, to secure the vital state interest of autonomy and security. This interest convergence between an ASEAN vanguard state and external actor caused ASEAN vanguard state resistance to sovereignty violation, from actors external to the region. Can ASEAN be conceptualized as a unitary actor when Thailand was the vanguard state? Based on the foregoing analysis, ASEAN can be conceptualized as an actor during those periods when ASEAN displayed a united front in support of vanguard state interests. Evidence of minor deviations from cohesion should not result in denial of group actor designation. ${ }^{264}$ Accordingly, those deviations from unitary action made by Indonesia and Malaysia during the Cambodian conflict do not result in denial of group actor status, because these deviations did not compromize the united front that ASEAN portrayed from late 1979 till the end of the conflict in 1991.

Analysis has shown that in the case of the Third Indochina War, behavioural cohesion was a response to the external threat posed by the Soviet Union and Vietnam. According to Stephen Walt, 'external threats are the most frequent cause of international alliances' ${ }^{265}$ Facing a threat, states seek to engage in balancing behaviour because 'they place their survival at risk if they fail to curb a potential hegemon before it becomes too strong'. ${ }^{266}$ State interests are therefore premised on the basic point of seeking survival. This is consistent with the work of Crawford and Press, who define vital state interests as involving 'self-preservation, political independence, and, by extension, defence of strategically vital areas'. ${ }^{267}$ As the evidence has shown, in its pursuit of survival, Thailand actively sought maximum great-power commitment to its security interests. ${ }^{268}$ In conjunction with the rest of ASEAN, Thailand was able to affect the regional distribution of power by adding to the resources of China and the US while constraining that of Vietnam and the Soviet Union. ${ }^{269}$ The case in question therefore meets vanguard state theory's expectations. 


\section{Contrasting theoretical arguments}

The consensus among the constructivists studying ASEAN is that the organization's governing norms emphasize dialogue, consensusbuilding and non-confrontation. What happens when the organization's norms are challenged? Constructivist theorists interpret the Third Indochina War as a challenge to ASEAN norms, cohesion and unity. ${ }^{270}$ However, their accounts of this case are at times limited, suggesting a need to look for alternative explanations. Ba states, 'Vietnam's action clearly challenged the idea of a unified and resilient Southeast Asia', while Thailand's subsequent alliance relationship with China 'represented a real test of the regional autonomy goals'. ${ }^{271}$ Ba concedes that 'it would take some rhetorical contortions to make Thai actions consistent with what was agreed should be the ASEAN project of regional resilience'. ${ }^{272}$ However, she continues to maintain that their ability to work together 'provided an important affirmation of their efforts and [italics in text] their solidarity as a group'. ${ }^{273}$

Despite challenges, Ba maintains that 'shared ideas of region and the importance of regional unity might ... have been the only [italics in text] significant thing that kept them [ASEAN] working together toward a common solution'. ${ }^{274}$ In this view, ideas about Southeast Asia's 'division and foreign intervention' find expression in 'ideas of resilience and "One Southeast Asia". ${ }^{275}$ Arguably, this overestimates the role of ideas in the historical record of this case study. Evidence presented here suggests that ASEAN cooperation was actually based on regional security concerns, rather than shared ideas of regional unity. Ba's analysis of the conflict also underemphasizes the important role played by external powers. Ba acknowledges that Thai actions 'legitimat[ed] China's involvement in Southeast Asia'. ${ }^{276}$ However, she fails to examine the critical role China, and the US, played in the conflict's resolution. This presents an account of the conflict that is at odds with this period of Southeast Asia's history.

Other constructivists maintain that the Third Indochina War was a success for ASEAN, which emerged from the conflict strengthened in its mission and core norms. According to Acharya, ASEAN 'presented the Vietnamese invasion as a gross violation of the principle of nonintervention in the internal affairs of states as well as the principle of non-use of force in interstate relations'. ${ }^{277}$ As events developed, the conflict gave 'a more substantive meaning to ASEAN political and security cooperation', ${ }^{278}$ while also having 'positive effects for ASEAN's pursuit of a regional identity'. ${ }^{279}$ In this view, the conflict 'motivated ASEAN members to overcome conflicting security interests 
and territorial disputes within the grouping, thereby moving it further on the path towards a security community'. ${ }^{280}$ The account presented here does not deny the record of ASEAN cooperation, but emphasizes that it has been misinterpreted. To be specific, the role of ASEAN has been elevated, while that of external powers has been systematically downplayed, with important theoretical consequences. Indeed, Jürgen Haacke, who has studied ASEAN's diplomacy in the Third Indochina War, reaches a very different conclusion to Acharya, noting that ultimately, 'all of ASEAN had to bow to the pressure of major powers and accept the political compromize [sic] that was presented as a fait accompli'. ${ }^{281}$

A second strand in the literature is represented by the realist perspective. Michael Leifer, David Martin Jones and Michael Smith contend that ASEAN's preference for consensus and conflict avoidance has lent itself to extra-regional actors manipulating ASEAN norms to serve their own best interests. ${ }^{282}$ Leifer, Jones and Smith all view ASEAN's role in the Cambodia conflict as subordinate to that of the external powers. According to Leifer, the role of China represented a 'much more effective means by which to challenge Vietnam's hegemonic position than the diplomatic support of ASEAN'. ${ }^{283}$ Because of this, the position 'adopted by the Association favoured China's interests, above all'. ${ }^{284}$ Jones and Smith also minimize ASEAN's role in the resolution of the Third Indochina War, maintaining that the eventual settlement 'represented an archetypal manifestation of great power politics'. ${ }^{285}$ According to this view, 'ASEAN's actual contribution to the Cambodian settlement reveals its role to be both ambiguous and ultimately limited'. ${ }^{286}$ The Association only appeared effective 'because its actions coincided with superpower interests', with ASEAN acting as 'a convenient front for external actors and interests'. ${ }^{287}$ For Jones and Smith, the fact that China and the Soviet Union effectively resolved the conflict through bilateral diplomacy, illustrated 'the region's continuing dependence upon external actors and the illusory character of ASEAN's attempt to erect a cordon sanitaire around Southeast Asia'.288

This perspective advanced by Leifer, Jones and Smith is difficult to reconcile with the facts. China and the US clearly saw ASEAN, and Thailand in particular, as a critical actor in opposing Vietnam. Any account of this case must therefore focus on the importance of SinoThai cooperation. While Leifer does give some consideration to the 'differential impact on the actual security interests' of the ASEAN member states, these are viewed as relatively ineffective. ${ }^{289}$ Thus, the alternative approaches to resolving the problem of Vietnam's invasion 
are interpreted as arising 'from a natural divergence of strategic perspectives, which has been an important factor in denying the Association a conventional security role'. ${ }^{290}$ The critical point to note is that Leifer does not seek to develop a connection between external power and regional state interests. As such, ASEAN state interests remain hostage to those of China, and regional autonomy remains wholly reliant on external actors. For Jones and Smith, ASEAN only appeared effective because its actions coincided with the interests of China and the US. This approach takes an overly restrictive view of ASEAN autonomy and the role of ASEAN states. As this chapter has shown, Thailand also sought to secure its own interests as a response to the Vietnamese threat, and worked with ASEAN to prevent a Vietnamese fait accompli. Jones and Smith offer an accurate portrayal of the role of great powers in Indochina during the Cold War; they minimize the ASEAN role. As such, there remain limitations in their analysis.

For Lee Jones, ASEAN responded to Vietnam's invasion of Cambodia 'not to defend its non-interference principle, but rather to contain revolution in Indochina'. ${ }^{291}$ To this end, the ASEAN states 'engaged in counter-intervention, fomenting civil war inside Cambodia to keep Vietnamese forces pinned down and unable to support revolutionary movements outside Indochina'. ${ }^{292}$ The Vietnamese threat is 'not understood in conventional, military, balance-of-power terms' but in terms of 'the likely consequences of the invasion for the balance of forces within their own societies'. ${ }^{293}$ The differing ASEAN responses to the Vietnamese invasion are explained as 'stemming from intra-elite splits and differences in domestic social conflicts'. ${ }^{294}$ Despite these differences, Jones maintains that 'a shared determination to uphold capitalist social order in the region underpinned ASEAN's basic cohesion'. ${ }^{295}$

Jones' overwhelming focus on social conflict within individual ASEAN states leaves a number of important factors under-theorized. By focusing predominantly on the domestic politics of regional states, the role of external powers in the conflict has been minimized. Jones makes no mention of the role of the Soviet Union, despite the integral part Moscow had in the conflict. While Jones refers to China's desire to counter 'Soviet-initiatives' in his narrative, his focus on the Sino-Thai relationship seems to consist largely of China's reduced support for the CPT in Thailand, and the effect this had on Thailand's social order. ${ }^{296}$ This focus on domestic factors underemphasizes the mutual security concerns of Thailand, China and the US, and deemphasizes legitimate and real fears of Vietnamese expansion on the 
part of ASEAN states. Moreover, as evidence provided in this chapter has shown, ASEAN's basic cohesion in the aftermath of the invasion was less to do with a determination to uphold capitalist social order, and more to do with concerns for regional security. These concerns were exacerbated after the influx of refugees into the region, and Vietnamese incursions into Thai territory. These important facets of the Third Indochina War case study are missing from Jones' argument, suggesting the need for an additional approach.

As this chapter has instead attempted to show, a realist external actorASEAN interest convergence model is effective in explaining ASEAN's resistance to sovereignty violation during the Third Indochina War. Interest convergence between Thailand and China regarding the Vietnamese threat meant that Thailand (and by extension ASEAN) was able to resist sovereignty violation from an expansionist Vietnam. Conversely, China was able to use Thailand, and by extension ASEAN, to support its Vietnam policy in Southeast Asia.

\section{Notes}

1 Content from this chapter originally published in Journal of Asian Security and International Affairs, Vol. 2 No. 2. Copyright 2015 (C) SAGE Publications India Private Limited, New Delhi. All rights reserved. Reproduced with the permission of the copyright holders and the publishers, SAGE Publications India Pvt. Ltd, New Delhi.

2 William Turley and Jeffrey Race, “The Third Indochina War", Foreign Policy 38 (Spring, 1980), 92.

3 Turley and Race, "The Third Indochina War", 92.

4 US Department of State, Foreign Relations of the United States, 19771980, Vol. XIII, China, ed. David P Nickles (Washington: United States Government Printing Office, 2013), 205.

5 US Department of State, Foreign Relations of the United States, Vol. XIII, 205.

6 Nicholas Khoo, Collateral Damage: Sino-Soviet Rivalry and the Termination of the Sino-Vietnamese Alliance (Columbia University Press: New York, 2011). 131.

7 Kosal Path, "China's Economic Sanctions against Vietnam, 1975-1978”, The China Quarterly 212 (December 2012), 1044.

8 Khoo, Collateral Damage, 111.

9 Leszek Buszynski, Soviet Foreign Policy and Southeast Asia (New York: St. Martin's Press, 1986), 156.

10 Douglas Pike, "Communist vs. Communist in Southeast Asia", International Security 41, no. 1 (Summer, 1979), 25. 
11 Leszek Buzynski, “Vietnam Confronts China”, Asian Survey 20, no. 8 (1980), 831.

12 Pike, "Communist vs. Communist", 30.

13 Nayan Chanda, Brother Enemy: The War after the War (New York: Harcourt Brace Jovanovich Publishers, 1986), 95.

14 Khoo, Collateral Damage, 115.

15 Ben Kiernan, How Pol Pot Came to Power: Colonialism, Nationalism, and Communism in Cambodia, 1930-1975, 2nd ed. (New Haven, CT: Yale University Press, 2004), 297-300.

16 Chanda, Brother Enemy, 42.

17 Chanda, Brother Enemy, 64.

18 Paul R. Bartrop and Steven Leonard Jacobs, eds., Modern Genocide: The Definitive Resource and Document Collection (Santa Barbara, CA: ABC-CLIO, 2015), 530.

19 Bartrop and Jacobs, eds. Modern Genocide, 530.

20 Chanda, Brother Enemy, 4.

21 Khoo, Collateral Damage, 50.

22 Douglas Pike, Vietnam and the Soviet Union: Anatomy of an Alliance (London: Westview Press, 1987), 62.

23 Khoo, Collateral Damage, 55.

24 Khoo, Collateral Damage, 67.

25 Kissinger Transcripts, A Verbatim Record of US Diplomacy 1969-1977, The Digital National Security Archive, KT00663, http://gateway. proquest.com/openurl?url_ver=Z39.88-2004\&res_dat=xri:dnsa\&rft_ dat=xri:dnsa:article:CKT00663.

26 US Department of State, Foreign Relations of the United States, 1969-1976, Vol. XVIII, China 1973-1976, ed. David P Nickles (Washington, DC: United States Government Printing Office, 2008), 136.

27 US Department of State, Foreign Relations of the United States, Vol. XIII, 109.

28 US Department of State, Foreign Relations of the United States, Vol. XIII, 138.

29 US Department of State, Foreign Relations of the United States, Vol. XIII, 93.

30 US Department of State, Foreign Relations of the United States, Vol. XIII, 109.

31 US Department of State, Foreign Relations of the United States, Vol. XIII, 34, 35.

32 Turley and Race, "The Third Indochina War", 96.

33 Leifer, ASEAN and the Security of South-East Asia, 22.

34 US Department of State, Foreign Relations of the United States, Vol. E-12, 16. 

162.

36 (Canberra: ANU, 1984), 57-9.

41 Ang, Singapore, ASEAN and the Cambodia Conflict, 7.

42 Ang, Singapore, ASEAN and the Cambodia Conflict, 7.

43 Wikileaks Cable, "Meeting with Thai Foreign Minister Charunphan", The Wikileaks Public Library of US Diplomacy, 08 January 1975, 1975BANGKO00355_b. URL: https://www.wikileaks.org/plusd/ cables/1975BANGKO00355_b.html.

44 US Department of State, Foreign Relations of the United States, Vol. E-12, 15.

45 Following excerpts from FM Chatchai and Dr Kissinger meeting obtained from: National Security Archive, "Digitized Set of 2,100 Henry Kissinger "Memcons" Recounting the Secret Diplomacy of the Nixon-Ford Era", in National Security Archive Briefing Book No.193, ed. William Burr, 26 May 2006, http://nsarchive.gwu.edu/NSAEBB/NSAEBB193/, document 17.

46 Wikileaks Cable, "Visit of Thai FonMin Chatchi", The Wikileaks Public Library of US Diplomacy, 07 August 1975, 1975WELLIN02277_b, https:// wikileaks.org/plusd/cables/1975WELLIN02277_b.html.

47 Wikileaks Cable, "Thai FonMin Chartchai's Talks with Miki and Miyazawa", The Wikileaks Public Library of US Diplomacy, 07 October 1975, 1975TOKYO14290_b, https://wikileaks.org/plusd/ cables/1975TOKYO14290_b.html.

48 Wikileaks Cable, "Thai FonMin Chartchai's Talks with Miki and Miyazawa", 1975TOKYO14290_b.

49 Ang, Singapore, ASEAN and the Cambodia Conflict, 7.

50 Wikileaks Cable, "General Brown Meeting with General Panggabean", The Wikileaks Public Library of US Diplomacy, 08 April 1975, 1975JAKART04135_b, https://wikileaks.org/plusd/ cables/1975JAKART04135_b.html.

51 Wikileaks Cable, “General Brown Meeting with General Panggabean”, 1975JAKART04135_b.

52 Wikileaks Cable, "GOI Views on Cambodia and Vietnam", The Wikileaks Public Library of US Diplomacy, 11 April 1975, 1975JAKART04295_b, https://wikileaks.org/plusd/cables/1975JAKART04295_b.html. 
53 Wikileaks Cable, "GOM Recognizes PRG", The Wikileaks Public Library of US Diplomacy, 03 May 1975, 1975KUALA02386_b, https://wikileaks. org/plusd/cables/1975KUALA02386_b.html.

54 Wikileaks Cable, “GOM Recognizes PRG”, 1975KUALA02386_b.

55 Following excerpts from PM Lee and Dr Kissinger meeting in May 1975 obtained from: US Department of State, Foreign Relations of the United States, Vol. E-12, 297-298.

56 Wikileaks Cable, "Lee Kuan Yew Visits Thailand", The Wikileaks Public Library of US Diplomacy, 25 April 1975, 1975BANGKO07412_b, https:// wikileaks.org/plusd/cables/1975BANGKO07412_b.html.

57 Wikileaks Cable, "Lee Kuan Yew Visits Thailand”, 1975BANGKO07412_b.

58 US Department of State, Foreign Relations of the United States, Vol. E-12, 16.

59 Chanda, Brother Enemy, 35.

60 Chanda, Brother Enemy, 318.

61 Chanda, Brother Enemy, 318.

62 Michael Leifer, "Post Mortem on the Third Indochina War", The World Today 35, no. 6, (1979), 254.

63 Turley and Race, “The Third Indochina War”, 99.

64 Turley and Race, "The Third Indochina War", 99.

65 Chanda, Brother Enemy, 319.

66 Buszynski, "The Soviet Union and Southeast Asia”, 538.

67 Buszynski, "The Soviet Union and Southeast Asia”, 536-7.

68 Buszynski, Soviet Foreign Policy and Southeast Asia, 113.

69 Donald Weatherbee, "The Diplomacy of Stalemate", in Southeast Asia Divided: The ASEAN-Indochina Crisis, ed. Donald Weatherbee (Boulder: Westview Press, 1985), 8.

70 Buszynski, Soviet Foreign Policy and Southeast Asia, 88.

71 US Department of State, Foreign Relations of the United States, Vol. E-12, 16.

72 Buszynski, "The Soviet Union and Southeast Asia", 538.

73 Buszynski, "The Soviet Union and Southeast Asia", 539.

74 Buszynski, "The Soviet Union and Southeast Asia", 539.

75 Allen Whiting, "ASEAN Eyes China: The Security Dimension", Asian Survey 37, no. 4 (April 1997), 302.

76 Whiting, "ASEAN Eyes China”, 302.

77 Wikileaks Cable, "PRC's Emerging Policy in Southeast Asia", The Wikileaks Public Library of US Diplomacy, 15 October 1975, 1975HONGK12216_b, https://wikileaks.org/plusd/cables/1975HONGK12216_b.html.

78 Wikileaks Cable, "PRC's Emerging Policy in Southeast Asia", 1975HONGK12216_b. 
79 Rizal Sukma, Indonesia and China: The Politics of a Troubled Relationship (London: Routledge, 1999), 93.

80 US Department of State, Foreign Relations of the United States, Vol. E-12, 299.

81 Sukma, Indonesia and China, 93.

82 Sukma, Indonesia and China, 4, 94.

83 US Department of State, Foreign Relations of the United States, Vol. XVIII, 136.

84 US Department of State, Foreign Relations of the United States, Vol. XVIII, 136.

85 US Department of State, Foreign Relations of the United States, Vol. E-12, 297.

86 Wikileaks Cable, "Meeting with Thai Foreign Minister Charunphan", 1975BANGKO00355_b.

87 US Department of State, Foreign Relations of the United States, Vol. E-12, 424.

88 Chambers, "The Chinese and the Thai are Brothers", 610.

89 Chambers, "The Chinese and the Thai are Brothers", 610.

90 Pavin Chachavalpongpun, "Embedding Embittered History: Unending Conflicts in Thai-Cambodian Relations", Asian Affairs 43, no. 1 (2012): 81-102.

91 Chachavalpongpun, "Embedding Embittered History", 84.

92 Chanda, Brother Enemy, 51.

93 Stephen Morris, Why Vietnam Invaded Cambodia: Political Culture and the Causes of War (Stanford: Stanford University Press, 1999), 83.

94 Ang, Singapore, ASEAN and the Cambodia Conflict, 10.

95 Chambers, "The Chinese and the Thai are Brothers", 610.

96 Xiaoming Zhang, "China's 1979 War with Vietnam: A Reassessment", The China Quarterly, 184 (December 2005), 856.

97 Morris, Why Vietnam Invaded Cambodia, 39.

98 Morris, Why Vietnam Invaded Cambodia, 39-40.

99 Khoo, Collateral Damage, 92.

100 Chanda, Brother Enemy, 71.

${ }^{101}$ Edward O'Dowd, Chinese Military Strategy in the Third Indochina War: The Last Maoist War (London: Routledge, 2007), 33.

102 Khoo, Collateral Damage, 92.

103 Chanda, Brother Enemy, 73.

104 Chanda, Brother Enemy, 80.

${ }^{105}$ US Department of State, Foreign Relations of the United States, Vol. E-12, 95.

106 US Department of State, Foreign Relations of the United States, Vol. E-12, 95. 
107 US Department of State, Foreign Relations of the United States, Vol. E-12, 95.

108 Kiernan, 'The Demography of Genocide in Southeast Asia", 585.

109 Chanda, Brother Enemy, 83-84.

110 Khoo, Collateral Damage, 78.

111 Khoo, Collateral Damage, 92.

112 Ben Kiernan, The Pol Pot Regime: Race, Power, and Genocide in Cambodia under the Khmer Rouge, 1975-79 (New Haven, CT: Yale University Press, 1996), 128.

113 Kiernan, The Pol Pot Regime, 129.

114 Kiernan, The Pol Pot Regime, 129.

115 Chanda, Brother Enemy, 99.

116 Morris, Why Vietnam Invaded Cambodia, 85-86.

117 Following excerpts from November 1978 US Interagency Intelligence Memorandum obtained from: US Department of State, Foreign Relations of the United States, Vol. XIII, 152.

118 Leifer, "Post Mortem on the Third Indochina War", 249.

119 Leifer, "Post Mortem on the Third Indochina War", 249.

${ }^{120}$ Leifer, "Post Mortem on the Third Indochina War", 250.

${ }^{121}$ US Department of State, Foreign Relations of the United States, Vol. XIII, 125.

122 Pike, "Communist vs. Communist in Southeast Asia”, 27.

123 Pike, "Communist vs. Communist in Southeast Asia", 33.

${ }^{124}$ Khoo, Collateral Damage, 2011.

125 Buszynski, "Vietnam Confronts China”, 838.

126 Khoo, Collateral Damage, 126.

127 Khoo, Collateral Damage, 127.

128 Chambers, "The Chinese and the Thai are Brothers", 613.

129 Chambers, "The Chinese and the Thai are Brothers", 613.

130 Turley and Race, "The Third Indochina War", 98.

131 Pike, "Communist vs. Communist in Southeast Asia”, 31.

132 Pike, "Communist vs. Communist in Southeast Asia”, 31.

133 Turley and Race, "The Third Indochina War", 92.

${ }^{134}$ John Funston, "The Third Indochina War and Southeast Asia", Contemporary Southeast Asia 1, no. 3 (December 1979), 268.

${ }^{135}$ Funston, "The Third Indochina War and Southeast Asia”, 268.

136 Yearbook of the United Nations 1979, Vol. 33 (New York: Office of Public Information United Nations, 1979), 271.

137 Yearbook of the United Nations 1979, 271.

138 Yearbook of the United Nations 1979, 272.

139 Yearbook of the United Nations 1979, 273.

140 Yearbook of the United Nations 1979, 276. 
141 Yearbook of the United Nations 1979, 272.

${ }^{142}$ US Department of State, Foreign Relations of the United States, Vol. XIII, 205.

143 Zhang, "China's 1979 War with Vietnam: A Reassessment”, 859.

${ }^{144}$ Following excerpts from Premier Deng and President Carter's meetings of 29 and 30 January obtained: US Department of State, Foreign Relations of the United States, Vol. XIII, 205-206, 2012 (undated).

145 Chanda, Brother Enemy, 324.

146 US Department of State, Foreign Relations of the United States, Vol. XIII, 233.

147 Yearbook of the United Nations 1979, 280.

148 Yearbook of the United Nations 1979, 280.

149 Yearbook of the United Nations 1979, 280.

150 Zhang, "China's 1979 War with Vietnam: A Reassessment”, 863.

151 O'Dowd, Chinese Military Strategy in the Third Indochina War, 3.

152 Zhang, "China's 1979 War with Vietnam: A Reassessment”, 865.

153 Zhang, "China's 1979 War with Vietnam: A Reassessment”, 866.

154 Zhang, "China's 1979 War with Vietnam: A Reassessment”, 866.

155 Zhang, "China's 1979 War with Vietnam: A Reassessment”, 867.

156 Yearbook of the United Nations 1979, 272.

157 Yearbook of the United Nations 1979, 272.

158 Association of Southeast Asian Nations, "Joint Press Statement, Special ASEAN Foreign Ministers Meeting on Indochinese Refugees”, Bangkok, 13 January 1979.

159 Following details of ASEAN's UN correspondence and General Committee deliberations and resolutions is obtained from: Yearbook of the United Nations 1979, 276, 284, 290, 293.

160 Buszynski, "The Soviet Union and Southeast Asia”, 543.

161 Buszynski, "The Soviet Union and Southeast Asia”, 544.

162 Turley and Race, "The Third Indochina War", 102, 98.

163 Pike, Vietnam and the Soviet Union, 208.

164 Buszynski, "The Soviet Union and Southeast Asia”, 541.

165 Chanda, Brother Enemy, 325.

166 Funston, "The Third Indochina War and Southeast Asia", 280.

167 Sukma, Indonesia and China, 96.

168 Leifer, ASEAN and the Security of South-East Asia, 102-3.

169 Leifer, "Post Mortem on the Third Indochina War", 255.

170 Sheldon Simon, "The Two Southeast Asias and China: Security Perspectives", Asian Survey 24, no. 5 (1984), 527.

${ }^{171}$ Funston, "The Third Indochina War and Southeast Asia", 282.

${ }^{172}$ Leifer, ASEAN and the Security of South-East Asia, 96.

173 Yearbook of the United Nations 1979, 276. 
174 Yearbook of the United Nations 1979, 277.

175 Pike, Vietnam and the Soviet Union, 212-13.

176 Yearbook of the United Nations 1979, 279.

177 Yearbook of the United Nations 1979, 279.

178 Leifer, ASEAN and the Security of South-East Asia, 108.

179 Leifer, ASEAN and the Security of South-East Asia, 108, 97.

${ }^{180}$ Funston, "The Third Indochina War and Southeast Asia", 281.

181 Turley and Race, "The Third Indochina War”, 109.

182 Turley and Race, “The Third Indochina War", 109.

183 Weatherbee, "The Diplomacy of Stalemate", 11.

${ }^{184}$ Sheldon Simon, "The Superpowers in Southeast Asia: A Security Assessment", in Southeast Asia Divided, 75.

185 Buszynski, "The Soviet Union and Southeast Asia”, 542-3.

186 Turley and Race, "The Third Indochina War", 108.

187 Turley and Race, "The Third Indochina War”, 108.

188 Simon, "The Superpowers in Southeast Asia", 76-77.

189 Simon, "The Superpowers in Southeast Asia”, 76-77.

190 Chanda, Brother Enemy, 348-9.

${ }^{191}$ US Department of State, Foreign Relations of the United States, Vol. XIII, 275.

192 Chambers, "The Chinese and the Thai are Brothers", 614.

193 Following excerpts from President Carter and Vice Premier Deng January 1979 conversation obtained from: US Department of State, Foreign Relations of the United States, Vol. XIII, 205.

194 US Department of State, Foreign Relations of the United States, Vol. XIII, 252.

${ }^{195}$ Following excerpts from VP Walter Mondale and Vice Premier Deng August 1979 meeting obtained from: US Department of State, Foreign Relations of the United States, Vol. XIII, 265.

196 Ang, Singapore, ASEAN and the Cambodia Conflict, 163.

197 Ang, Singapore, ASEAN and the Cambodia Conflict, 163.

198 Chambers, "The Chinese and the Thai are Brothers", 601.

199 Chambers, "The Chinese and the Thai are Brothers", 618.

200 Chambers, "The Chinese and the Thai are Brothers", 618-9.

${ }^{201}$ Following excerpts from VP Mondale and Vice Premier Deng August 1979 meeting obtained from: US Department of State, Foreign Relations of the United States, Vol. XIII, 265.

202 Following excerpts from President Carter and Premier Hua July 1980 meeting obtained from: US Department of State, Foreign Relations of the United States, Vol. XIII, 313.

${ }^{203}$ Khoo, Collateral Damage, 91. 
${ }^{204}$ Robert Ross, "China and the Cambodian Peace Process: The Value of Coercive Diplomacy”, Asian Survey 31, no. 12 (1991), 1176.

205 Chambers, "The Chinese and the Thai are Brothers", 616.

206 Turley and Race, "The Third Indochina War", 108.

207 Leifer, ASEAN and the Security of South-East Asia, 91.

${ }^{208}$ Leifer, ASEAN and the Security of South-East Asia, 91.

209 Yearbook of the United Nations 1980, 331.

210 Michael Leifer, Singapore's Foreign Policy: Coping with Vulnerability (London: Routledge, 2000), 86.

211 Yearbook of the United Nations 1980, 331.

212 Yearbook of the United Nations 1980, 331.

213 US Department of State, Foreign Relations of the United States, Vol. XIII, 265.

${ }^{214}$ US Department of State, Foreign Relations of the United States, Vol. XIII, 265.

215 Funston, "The Third Indochina War and Southeast Asia”, 271.

216 Yearbook of the United Nations 1980, 331.

217 Yearbook of the United Nations 1980, 331.

218 Yearbook of the United Nations 1980, 320.

219 The following details relating to the International Conference on Kampuchea and subsequent resolution has been obtained from: Yearbook of the United Nations 1981, Vol. 35 (New York: Office of Public Information United Nations, 1981), $239-249$.

220 Yearbook of the United Nations 1981, 240.

221 Yearbook of the United Nations 1981, 240.

222 Yearbook of the United Nations 1981, 249

${ }^{223}$ Yearbook of the United Nations 1982, Vol. 36 (New York: Office of Public Information United Nations, 1982), 335.

224 Yearbook of the United Nations 1982, 335.

225 Simon, "The Two Southeast Asias and China", 526.

226 Simon, "The Two Southeast Asias and China", 526.

227 Yearbook of the United Nations 1984, Vol. 38 (New York: Office of Public Information United Nations, 1984), 214.

228 Yearbook of the United Nations 1983, Vol. 37 (New York: Office of Public Information United Nations, 1983), 227.

229 Yearbook of the United Nations 1985, Vol. 39 (Dordrecht: Martinus Nijhoff Pub, 1985), 230.

230 Yearbook of the United Nations 1985, 230.

231 Sukma, Indonesia and China, 95.

232 Leifer, ASEAN and the Security of South-East Asia, 101.

233 Ang, Singapore, ASEAN and the Cambodia Conflict, 105.

${ }^{234}$ Ang, Singapore, ASEAN and the Cambodia Conflict 162. 
235 Weatherbee, "The Diplomacy of Stalemate", 12.

236 Simon, "The Two Southeast Asias and China", 528.

${ }^{237}$ Leifer, ASEAN and the Security of South-East Asia, 106.

238 Weatherbee, "The Diplomacy of Stalemate", 12.

239 Buszynski, Soviet Foreign Policy and Southeast Asia, 224.

${ }^{240}$ Leifer, ASEAN and the Security of South-East Asia, 106.

241 Ang, Singapore, ASEAN and the Cambodia Conflict, 88.

${ }^{242}$ Leifer, ASEAN and the Security of South-East Asia, 106.

243 Buszynski, "The Soviet Union and Southeast Asia", 544.

${ }^{244}$ Leifer, ASEAN and the Security of South-East Asia, 107.

245 Ross, "China and the Cambodian Peace Process", 1178.

246 Ang, Singapore, ASEAN and the Cambodia Conflict, 74.

247 Ang, Singapore, ASEAN and the Cambodia Conflict,110.

248 Ang, Singapore, ASEAN and the Cambodia Conflict,110.

249 Ang, Singapore, ASEAN and the Cambodia Conflict,110.

250 Ang, Singapore, ASEAN and the Cambodia Conflict, 120-121.

251 Ang, Singapore, ASEAN and the Cambodia Conflict, 120-121.

252 Ang, Singapore, ASEAN and the Cambodia Conflict, 121.

253 Yearbook of the United Nations 1989, Vol. 43 (The Hague: Martinus Nijhoff Pub, 1989), 178.

254 Ang, Singapore, ASEAN and the Cambodia Conflict, 161-2.

255 Yearbook of the United Nations 1989, 178.

256 Yearbook of the United Nations 1989, 178.

257 Ross, "China and the Cambodian Peace Process", 1174.

258 Ross, "China and the Cambodian Peace Process", 1174.

259 Pike, Vietnam and the Soviet Union, 200.

260 Pike, Vietnam and the Soviet Union, 200.

261 Ross, "China and the Cambodian Peace Process", 1175.

262 Yearbook of the United Nations 1990, Vol. 44 (The Hague: Martinus Nijhoff Pub, 1990), 211.

263 Yearbook of the United Nations 1990, 211.

${ }^{264}$ Frey, "The Problem of Actor Designation in Political Analysis", 144.

265 Walt, The Origins of Alliances, 148.

266 Walt, The Origins of Alliances, 18.

267 Crawford, Pivotal Deterrence, 31.

${ }^{268}$ Ciorciara, The Limits of Alignment, 2.

269 Ciorciara, The Limits of Alignment, 1.

270 Acharya, Constructing a Security Community, 79; Ba, [Re]Negotiating East and Southeast Asia, 85; Haacke, ASEAN's Diplomatic and Security Culture, 111.

${ }^{271} \mathrm{Ba},[$ Re]Negotiating East and Southeast Asia, 86.

$272 \mathrm{Ba},[$ Re]Negotiating East and Southeast Asia, 86.

$273 \mathrm{Ba},[$ Re]Negotiating East and Southeast Asia, 87. 
${ }^{274} \mathrm{Ba},[R e]$ Negotiating East and Southeast Asia, 87.

$275 \mathrm{Ba}$, [Re]Negotiating East and Southeast Asia, 29.

${ }^{276} \mathrm{Ba},[$ Re]Negotiating East and Southeast Asia, 86.

277 Acharya, Constructing a Security Community, 92.

278 Acharya, The Making of Southeast Asia, 195.

279 Acharya, Constructing a Security Community, 92.

280 Acharya, Constructing a Security Community, 92.

${ }^{281}$ Haacke, ASEAN's Diplomatic and Security Culture, 111.

282 Jones and Smith, "Making Process, Not Progress", 150.

283 Leifer, ASEAN and the Security of South-East Asia, 97.

${ }^{284}$ Leifer, ASEAN and the Security of South-East Asia, 98.

285 Jones and Smith, ASEAN and East Asian International Relations, 55.

${ }^{286}$ Jones and Smith, ASEAN and East Asian International Relations, 54.

287 Jones and Smith, ASEAN and East Asian International Relations, 55.

288 Jones and Smith, ASEAN and East Asian International Relations, 55.

${ }^{289}$ Leifer, ASEAN and the Security of South-East Asia, 90.

${ }^{290}$ Leifer, ASEAN and the Security of South-East Asia, 90

${ }^{291}$ Jones, ASEAN, Sovereignty and Intervention in Southeast Asia, 76.

${ }^{292}$ Jones, ASEAN, Sovereignty and Intervention in Southeast Asia, 76.

${ }^{293}$ Jones, ASEAN, Sovereignty and Intervention in Southeast Asia, 78.

${ }^{294}$ Jones, ASEAN, Sovereignty and Intervention in Southeast Asia, 89.

${ }^{295}$ Jones, ASEAN, Sovereignty and Intervention in Southeast Asia, 89.

${ }^{296}$ Jones, ASEAN, Sovereignty and Intervention in Southeast Asia, 89. 


\section{4 \\ The East Timor Humanitarian Crisis}

At the time of Indonesia's 1975 invasion and occupation of East Timor, and in the two decades that followed, the US and Australia maintained consistent support for the Suharto regime. Despite UN condemnation of Indonesia's actions with respect to East Timor, these external powers sought to mute international criticism, whilst strengthening relations with a state deemed to be of continued strategic significance. However, a sea change was in evidence by the late 1990s. While Indonesia maintained the backing of the ASEAN states, it had lost support from the US and Australia, its key external power allies. In the context of the Asian Financial Crisis of 1997, ${ }^{1}$ Indonesia was pressured by these powerful non-ASEAN states into allowing a popular consultation in East Timor in 1999. The subsequent humanitarian crisis resulted in these external powers, in conjunction with the UN and wider international community, forcing Indonesia to accept external intervention by way of a UN-sponsored peacekeeping force. This act significantly undermined ASEAN autonomy. ${ }^{2}$ Had external intervention not occurred, it is unlikely that Indonesia would have permanently withdrawn its forces from East Timor.

Through analysis of the humanitarian crisis in East Timor, evidence will be provided to support the hypothesis that in 1999, ASEAN's failure to resist violations to the sovereignty of Indonesia was a consequence of low interest convergence between Indonesia and the external powers. During this period, Indonesia continued to have the most compelling interests at stake in the future of East Timor, having incorporated the territory as the archipelago's 27th province in 1976. As the vanguard state, Indonesia was able to apply continued pressure on the ASEAN states to obtain strong regional support for Indonesia's East Timor policy, and to portray a united ASEAN front in the face of 
external intervention. However, the key factor explaining Indonesia's failure to resist sovereignty violation in 1999 resides in the critical role played by external actors.

Following the Asian Financial Crisis of 1997, the regional repercussions of Indonesia's economic and domestic instability generated concern in the US and Australia. Interest divergence led these external powers to apply pressure on Indonesia to elicit change over East Timor. In a weakened state, Indonesia was coerced into accepting an international peacekeeping force in East Timor, despite asserting that such a force would constitute an unacceptable breach of its state sovereignty. Critically, ASEAN institutional cohesion alone was not sufficient to prevent Indonesian sovereignty violation. This supports the view that, as a collection of weak states, ASEAN is unable to affect the international security landscape on its own. ${ }^{3}$ Indeed, as one commentator noted, the crisis consolidated the view held by many that ASEAN was 'chronically incapable of taking meaningful action even when its own interests are directly engaged'. As this chapter will attempt to show, ASEAN autonomy is much more contingent than currently portrayed in much of the existing non-realist literature.

The chapter will begin with an assessment of Indonesia's position in the post-Cold War regional environment. During this period, which was characterized by a continuation of human rights abuses in East Timor, Indonesia continued to receive support from external powers such as the US and Australia. Interest convergence between Indonesia, Australia and the US regarding the formers' East Timor policy remained high. Indonesia was also able to maintain pressure on the ASEAN states to support its East Timor policy, thus spearheading a united ASEAN front. The discussion will subsequently show the devastating impact of the 1997 Asian Financial Crisis on Indonesia's economy and domestic system. At this time, there was a loss of confidence in the Indonesian regime, and a divergence in interests between Indonesia, Australia, and the US. Despite this external power interest divergence, ASEAN maintained its support for Indonesia during a period of great regional economic instability. This support was ultimately to the detriment of the Association.

The chapter will then examine the pressure external powers placed on Indonesia to accept a process of consultation in East Timor after the financial crisis. It will consider East Timor's subsequent vote for independence, the devastating humanitarian crisis that ensued, and the international community's responses to the crisis. Particular attention will focus on the additional pressure placed on Indonesia, which ultimately paved the way for external intervention in the territory. 
The analysis will then address Indonesia's failure to resist sovereignty violation by way of a UN mandated peacekeeping force, and the period of UN sovereignty in East Timor approved by the Security Council in October 1999. The chapter will conclude with a theoretical assessment of the findings and consideration of the contending arguments for the humanitarian crisis in East Timor.

\section{Indonesia in the post-Cold War regional environment}

In the period after 1975, Indonesia was largely successful in keeping East Timor off the international agenda. This was due to two reasons. First, as will be shown, Indonesia maintained the support of key external powers such as the US and Australia. These powers were proactive in deflecting negative attention away from Indonesia's East Timor policy. Second, Indonesia was able to ban foreign journalists from entering East Timor, thus cutting the region off from the international community. ${ }^{5}$ When journalists were allowed to enter the region, this was always in the company of Indonesian officials. ${ }^{6}$

East Timorese cultural and political resistance increased through the 1980s. Fighting between FALINTIL, the military wing of FRETILIN, and Indonesian armed forces continued throughout this period. The severity of FRETILIN resistance led Indonesian President Suharto to increase troop levels in East Timor to 14,000-20,000 in 1984, and to declare a state of emergency in the region on 9 September 1985. ${ }^{7}$ Suharto attempted to normalize Jakarta's control in East Timor in 1988, when he declared that the territory had equal status with Indonesia's other 26 provinces. ${ }^{8}$ As such, East Timor was provided with a government structure identical to Indonesia's other provinces. Travel restrictions were also lifted, which allowed East Timorese to leave the region, and Indonesian and foreign visitors to enter. This was exemplified by a visit from Pope John Paul II in October 1989.

Despite normalisation, East Timorese political factions staged public protests while engaging in support for FALINTIL. ${ }^{9}$ One such demonstration against the Indonesian government occurred at the Santa Cruz cemetery in the East Timor capital of Dili on 12 November 1991. More than 2000 unarmed East Timorese were present at the cemetery, to commemorate the death of an underground member killed by Indonesian security forces. ${ }^{10}$ The memorial procession was attacked by Indonesian troops after the demonstrators chanted slogans, displayed independence banners and unfurled the FRETILIN flag. ${ }^{11}$ 
The official death toll was initially declared at 19 and later revised to $50 .{ }^{12}$ Local activists claimed as many as 273 deaths, with many more injured, and up to 255 missing after large-scale arrests. ${ }^{13}$ For some commentators, the massacre was the 'critical turning point in East Timor's path to independence'. ${ }^{14}$ The relaxation of the ban on foreign journalists in the area meant that many witnessed and recorded the violence. Max Stahl, an activist journalist, was filming at the cemetery when Indonesian troops opened fire. Stahl was able to hide this film and smuggle it from the country with the assistance of a foreign aid worker. As Kingsbury notes, when the footage aired, Indonesia's 'woeful human rights record was back in the international spotlight', putting 'the question of East Timor firmly back on the international agenda'. ${ }^{15}$

The death of an Australian human rights activist during the massacre came as a particular embarrassment for the Australian government, which had officially recognized Indonesian sovereignty over East Timor in December 1989, by signing the Timor Gap 'Zone of Cooperation Agreement', allowing for joint exploration of Timor Gap natural resources. ${ }^{16}$ As international condemnation of Indonesia increased, the government went into 'public relations damage control mode', where an inquiry was held and a regional commander relieved of his post. ${ }^{17}$ However, this did little to silence Indonesia's critics. These changes in events culminated in the Nobel Peace Prize for 1996 being awarded to the East Timorese Bishop Carlos Felipe Ximenes Belo and Foreign Minister in exile José Ramos-Horta, for 'their work towards a just and peaceful resolution to the conflict in East Timor'. ${ }^{18}$ This was specifically intended to 'spur efforts to find a diplomatic solution to the conflict in East Timor based on the people's right to self-determination'. ${ }^{19}$

While the Santa Cruz massacre in 1991 was an important event in Indonesia's occupation of East Timor, it is important to note that, despite worldwide condemnation of Indonesia, there were no serious calls for intervention following the massacre. Despite evidence of ongoing and serious human rights abuses against the East Timorese people, it would be eight more years before the international community would attempt to intervene in East Timor. This suggests that while the Santa Cruz massacre was an important factor in East Timor's eventual independence, it was not the 'critical turning point' claimed by some. ${ }^{20}$ There were no calls for intervention in 1991 because Indonesia maintained the support of two important external powers: the US and Australia. With external power support, Indonesia was able to maintain its control over East Timor for the majority of 
the 1990s. It would take a catalytic event before Indonesia lost this external power support, an event that would directly impinge on external power state interests.

\section{Indonesia-state interest convergence in the post- Cold War period}

In the wake of the Santa Cruz massacre, US Senators Claiborne Pell, the chairman of the Senate Foreign Relations Committee, and David Boren, chairman of the Select Committee on Intelligence, visited Indonesia. There, they stated that despite being concerned by the killings, any specific steps to reconciliation with the East Timorese 'were a matter for the Indonesian government to decide because this was an internal affair of the country'. ${ }^{21}$ Similar sentiments were echoed by the US Ambassador in Jakarta, Robert Barry. In 1994, Mr Barry stated that 'the human-rights issue will not be detrimental to the future of ties between the US and Indonesia', and that his government 'from the start accepted [East Timor's] incorporation into Indonesia'. ${ }^{22}$

From March 1992, US support for the Indonesian regime came under greater Congressional scrutiny. ${ }^{23}$ Both the US House of Representatives and the Senate within US Congress placed restrictions on the supply of arms and military aid to Indonesia. However, in 1997 the House Foreign Operations Appropriations Subcommittee 'heard administration testimony that the Pentagon sold Indonesia military training without congressional notification or consent throughout 1996' ${ }^{24}$ In 1998, released Pentagon documents showed that 'US Army and Marine personnel had trained Indonesian soldiers under the Joint Combined Exchange Training (JCET) program every few months since 1992' ${ }^{25}$ As part of this training, 'Indonesian troops were trained in air assault, urban warfare, and psychological operations thirty-six times [italics in text] between 1992 and 1997 without congressional knowledge or approval'. ${ }^{26}$ Much of this training went to Indonesia's Kopassus troops, widely acknowledged as having instigated numerous human rights violations during the invasion of East Timor. ${ }^{27}$

In addition to military training, the US continued to sell arms to the Indonesian government. In the year immediately after the Dili massacre, 'the State Department licensed more than 300 military sales to Indonesia'. ${ }^{28}$ President Bill Clinton met with Suharto annually from 1992 to 1998, at which times he would always raise the issue of human rights in East Timor. ${ }^{29}$ However, this stance was undoubtedly undermined by continued arms sales and continued joint military 
training. The foregoing analysis suggests that despite intense pressure from Congress, and despite acknowledged human rights abuses in East Timor, the US government's policy towards Indonesia and its occupation of East Timor had not significantly changed in the pre1997 period.

\section{Indonesia-Australia interest convergence}

Like the Clinton administration, the Australian government also continued its support for Indonesia in the period following the 1991 Santa Cruz massacre. In April 1992, Australian Prime Minister Paul Keating met Suharto in Jakarta, where the Santa Cruz massacre was not discussed. ${ }^{30}$ Keating confirmed in 1994 that 'no country is more important to Australia than Indonesia. If we fail to get this relationship right, and nurture and develop it, the whole web of our foreign relations is incomplete'. ${ }^{31}$ In 1995, Australian Foreign Affairs head Richard Woolcott claimed that 'the East Timor lobby should accept that the time for an act of self-determination after 20 years has passed and that demanding independence is a lost cause which raises false hopes, prolongs conflict and costs lives'. ${ }^{32}$

Bilateral ties were strengthened between Australia and Indonesia in 1992, with the establishment of an Australia-Indonesia Ministerial Forum designed to provide a platform for the expansion of economic ties, including agreements on investments and copyright protection. ${ }^{33}$ Canberra made it clear that Indonesian human rights abuses would not be allowed to affect bilateral trade and investment. Australian Foreign and Trade Minister Gareth Evans stated that 'Australia did not think it appropriate to make "routine linkages" between the two as that would be counterproductive'. ${ }^{34}$ In addition to enhanced trade and economic linkages, Australia was also focusing on 'building a much deeper and more consequential military and security relationship' with Indonesia. ${ }^{35}$ During this same period, the newly elected Australian Prime Minister Paul Keating travelled to Washington, at a time when Congress was seeking to restrict defence sales and training between the US and Indonesia, with the express intention of urging Clinton to withdraw human rights considerations from the drafting of defence contracts. ${ }^{36}$

By 1995, Indonesia held more military exercises with Australia than with any other country. ${ }^{37}$ The Royal Australian Navy (RAN) and Indonesian Navy conducted maritime warfare exercises four times a year. The Royal Australian Air Force (RAAF) and Indonesian Air Force conducted joint exercises annually. ${ }^{38}$ Kopassus units travelled to 
Australia for counter-terrorism and counter-hijacking training, 'despite objections that the force has been linked to serious human rights abuses'. ${ }^{39}$ In 1995, the Australian Defence Force (ADF) became 'the most important foreign provider of military training to Indonesia, having displaced the United States'. ${ }^{40}$ Increased relations between Australia and Indonesia culminated in the signing of a secret 'watershed treaty', in December 1995, known as the Australia-Indonesia Agreement on Maintaining Security. ${ }^{41}$ This treaty committed the Australian and Indonesian governments to consult at ministerial level about matters affecting their common security, consult each other in the case of adverse challenges to either party, or to their common security interests, and promote cooperative activities in the security field. ${ }^{42}$

A powerful Jakarta lobby, consisting of bureaucrats, academics and journalists, also had a significant impact on Australia's foreign policy with respect to Indonesia. The Jakarta lobby 'long regarded Australia's relationship with Indonesia as an exceptional case requiring careful management by "experts" with a proper sympathy for and understanding of Jakarta's difficulties'. ${ }^{43}$ This was a stance reflected by Richard Woolcott in 1995, when he confirmed that 'we cannot allow foreign policy to be made in the streets, by the media or by the unions'. ${ }^{44}$ The Jakarta lobby 'insisted that [Suharto's] human rights "failures" should be balanced against his economic achievements'. ${ }^{45}$

Following the massacre in Dili, the Jakarta lobby made 'concerted efforts to offset community outrage'. ${ }^{46}$ Richard Woolcott and journalist Greg Sheridan took steps to blame Portugal for the killings. An Australian National University Economics Professor stated that the massacre was a tragedy, not due to the loss of life, but because of the anti-Indonesian hate campaigns it had inflamed. ${ }^{47}$ The Jakarta lobby also took steps to minimize the number of victims of the massacre, and dismissed evidence of further massacres committed by Indonesian troops against the East Timorese. Clearly, in the post-Cold War period, Australia continued to view Indonesia as a key strategic regional partner. Canberra therefore prioritized good relations with Indonesia over concerns for human rights abuses committed by Indonesian forces in East Timor.

\section{Indonesia-ASEAN state interest convergence}

Despite the massacre of unarmed demonstrators in Santa Cruz, the ASEAN states continued their support for Indonesia's East Timor 
policy, taking whatever steps were necessary to obstruct further protest movements. The Nobel Peace prize award-giving ceremony in 1996, where East Timorese Bishop Carlos Felipe Ximenes Belo and Foreign Minister in exile José Ramos-Horta were to be honoured, was held in Oslo, Norway. Thailand, as the only ASEAN state to have an Embassy in Norway besides Indonesia, refused to attend the ceremony, making it clear that the Thai ambassador's attendance at the function would be 'inappropriate'. ${ }^{48}$ In May 1994, the Philippine President Fidel Ramos, responding to pressure from Jakarta, tried to ban an international conference on East Timor human rights in Manila. ${ }^{49}$ Jakarta warned the Philippines that 'the holding of such a conference in Manila may impair the friendly relations between the two countries' ${ }^{50}$

In an effort to placate Jakarta, President Ramos confirmed that 'the Philippines considers East Timor part of Indonesia as its 27 th province. This is a position which we took a long time ago'. ${ }^{51}$ Despite the Philippines constitution providing for freedom of association and free speech, Manila confirmed it would do everything it could, within the constitution's limits, to avoid damaging relations with Jakarta. ${ }^{52}$ Philippines' Secretary Raul Manglapus stated that Manila 'will not support any secessionist movement in Indonesia'. ${ }^{53}$ Ultimately, the Philippines made the decision to ban foreign participation at the conference. This meant that Mr Jose Ramos-Horta was blacklisted from attending. Indonesian Foreign Minister Ali Alatas welcomed the Philippines decision. Alatas argued that the conference had been 'inspired, planned and engineered by East Timorese exiles', and that the conference was 'leaning towards interference in Indonesia's territorial integrity'. ${ }^{54}$ The Chairman for the Asia-Pacific Coalition for East Timor (APCET) argued that the Philippines' decision was evidence of Manila's 'clear surrender to Indonesian pressure. Indonesia has succeeded in invading the Philippines - not in military terms ... but in foreign policies and diplomatic work' ${ }^{55}$ However, President Ramos affirmed that 'the Philippine government has acted, as it will always act, in accordance with the national interest'. ${ }^{56}$

Plans for a human rights conference to be hosted by the Southeast Asian Human Rights Network (SEANET) in Thailand were met with similar consternation. The Thai government stepped up its control over the operations of international non-governmental organisations, requiring them to apply for permission for any planned activities 30 days in advance. ${ }^{57}$ This meant that SEANET conference organizers were unable to find a venue for the meeting. Thai officials feared that Bangkok might be used as a venue to criticize Indonesia in its handling of East Timor. ${ }^{58}$ As such, the Thai government sent 
plainclothes police to "monitor the movements of a group of foreign human rights organisation members' ${ }^{59}$ Thai Foreign Minister Prasong Soonsiri urged the human rights group 'to consider the adverse effects the meeting may have on relations between Thailand and Indonesia ... the meeting will not only strain relations between the two countries' ${ }^{6}{ }^{6}$

Ali Alatas informed the Thai Foreign Ministry that he may 'decide against attending the ASEAN meeting if the SEANET meeting is held in Bangkok' ${ }^{61}$ Indonesia also protested against a Thai newspaper, The Nation, after it 'carried two editorials critical of Indonesian policy on East Timor'. ${ }^{62}$ Thailand's Special Branch Police Bureau Assistant Commissioner Yothin Mattayomnan stated that 'police had been instructed to intervene and make arrests if the activities of NGO [Non-governmental Organisation] members threaten national security and the country's international relations' ${ }^{63}$ The Thai Prime Minister Chuan Leekpai denied that his administration was contravening its policy to promote human rights. Leekpai argued that Thailand 'must place the national interest before anything else while upholding the rights and freedom of all'. ${ }^{64}$

Manila banned Ramos-Horta from entering the country for a second time in October 1996, fearing he may disturb an upcoming Asia-Pacific Economic Cooperation (APEC) meeting scheduled for November. The House of Representative Speaker Jose de Venecia said that the decision had been taken 'in the national interest and in the ASEAN interest, out of respect for President Suharto, and in order to maintain serenity within APEC' ${ }^{65}$ Ramos-Horta was also banned from entering Bangkok in 1995 to teach a programme at a local university. In November 1996, the youth wing of the ruling government, the United Malays National Organisation (UMNO), broke up the AsiaPacific Conference on East Timor, convened in Kuala Lumpur. The Malaysian police went on to arrest more than 100 people, including 47 foreigners. ${ }^{66}$ These foreigners were subsequently deported. Indonesia expressed its 'highest appreciation' to the Malaysian government for shutting down the conference. ${ }^{67}$ The Malaysian decision 'reflected the ASEAN members' commitment not to interfere in the affairs of other countries, and their highest solidarity'. ${ }^{68}$

In December 1996, ASEAN warned the European Union that continued scrutiny of extraneous issues such as East Timor could aggravate relations between the two organisations. This statement was the first time ASEAN as a group 'formally cautioned another grouping against poaching into the affairs of one of its members' ${ }^{69}$ This statement had the desired effect. During EU-ASEAN dialog in February 1997, EU foreign ministers skirted the issue of East Timor, 
despite initially expressing a determination to press the topic. ${ }^{70}$ ASEAN officials expressed their satisfaction that 'East Timor was not included in the agenda'. ${ }^{71}$ According to Jakarta, 'ASEAN countries are aware East Timor would have been far worse off without Indonesian intervention. No ASEAN country would have endorsed a "Cuba" on Indonesia's doorstep' ${ }^{72}$ It is apparent from these findings that ASEAN support was a key component in Indonesia's East Timor policy. Within the region, Indonesia was determined to keep East Timor off the agenda, by any means necessary. The ASEAN states recognized this, and did everything in their power to placate Jakarta. Maintaining positive relations with Indonesia was as a key national interest at this time.

\section{The Asian Financial Crisis (1997) - a catalyst for change}

Relations between Indonesia, Australia and the US remained strong in the period up to 1997, despite a change in the regional environment following the end of the Cold War. Levels of interest convergence had been maintained in the absence of a common unifying threat, through joint exports and direct investments. The US had strong economic ties with Indonesia, with US exports between 1986 and 1993 tripling from US $\$ 795$ million to US $\$ 2.8$ billion. ${ }^{73}$ AustraliaIndonesia two-way trade also grew rapidly, from $\$ A U 2.2$ billion in 1990-91 to \$AU4.3 billion in 1995-96, a growth rate of approximately 14.5 percent a year. ${ }^{74}$ Australia also had direct investments in Indonesia totalling some AUS $\$ 2.5$ billion. ${ }^{75}$ Clearly, the US and Australia had much at stake in Indonesia. It was in external power interests to see a strong and stable Indonesia in Southeast Asia. The Asian Financial Crisis of 1997 acted as a catalyst for change, with Indonesia's subsequent economic and domestic collapse seriously impacting external power interests. Following the crisis, a decrease in interest convergence between Indonesia and these external powers would lead to the first significant calls for intervention in East Timor, and would culminate in Indonesia's failure to resist sovereignty violation from actors external to the region.

\section{Background to the Asian Financial Crisis}

The Asian Financial Crisis first manifested in Thailand, in early 1997. At that time, the Thai baht began to crumble as a result of a number of 
factors, including 'imprudent domestic lending practices, an imbalance between short-term and long-term financing, and an unrealistic exchange rate pegged to the US dollar. ${ }^{76}$ When doubts grew regarding Thailand's ability to maintain the baht to the dollar, investors began to sell their currency. Despite the Bank of Thailand attempting to float the baht on the international money market, it fell quickly by 10 percent. As it continued to weaken, confidence in the value of the currency was further undermined. By August 1997, evidence of similar short-term debt financing became apparent in Indonesia. In the late 1980s, a large number of private banks were created within Indonesia, which were 'poorly managed and prone to making risky or politically motivated loans.' ${ }^{77}$ During the 1990s, Indonesia's foreign debt increased to approximately US $\$ 80$ billion, with much of this short-term debt financing speculative investments in real estate. ${ }^{78}$ The Suharto government supported cronyism, unsound banking practices and maintained market-distorting monopolies, something the World Bank was reportedly aware of. ${ }^{79}$

The Suharto regime's record of economic growth also failed to take into account the poor distribution of wealth or the excessive accumulation of wealth to a small number of elites. ${ }^{80}$ These practices increased the Suharto family's estimated worth to over US $\$ 30$ billion. ${ }^{81}$ After devaluation of the Thai baht, investors questioned the strength of the rupiah, which they subsequently sold to buy the US dollar. As in Thailand, the Indonesian Central Bank attempted to float the rupiah on the international money market. This led to a rapid depreciation of the currency, which lost 81 percent. ${ }^{82}$ Collapse of the rupiah devastated the Indonesian economy. As a result, borrowers were unable to repay debts, banks were unable to secure foreign loans in an attempt to foster regrowth, and manufacturers were no longer able to afford raw materials to continue production.

\section{Indonesia's economic and domestic crisis}

As a result of Indonesia's economic crisis, inflation reached 80 to 100 percent. The rupiah reached its lowest point, at 17,000 to the US dollar. ${ }^{83}$ Banks became insolvent and businesses went bankrupt. Coupled with depreciation of the rupiah, International Monetary Fund (IMF) rates of interest reached as high as 50 to 60 percent, forcing further companies into insolvency. ${ }^{84}$ In 1997, unemployment in Indonesia passed 40 percent. Food shortages due to adverse weather the previous year meant that by early 1998, there were predictions 
that Indonesia would require 4 to 5 million tons of rice before 1999 to prevent starvation of vulnerable citizens ${ }^{85}$ Ultimately, Indonesia's failing economy led to mass unemployment, poverty and malnutrition, with nearly two-thirds of Indonesians in danger of falling below the poverty line in $1999 .{ }^{86}$ As a result of the crisis, Indonesia was forced to seek help from the IMF, which offered economic aid but demanded greater democratic and microeconomic reforms by return.

As part of the IMF support package, Indonesia was required to 'restructure certain banks, dismantle a quasi-governmental monopoly on all commodities (except rice), cut fuel subsidies, increase electricity rates, increase the transparency of public policy and budget-making processes, and speed up privatisation and reform of state enterprizes' ${ }^{87}$ Suharto openly criticized the stringent IMF package, informing the international community that no reform changes would be made. Indonesian government official Dim Syamsudin stated: 'I'm afraid there's a communications breakdown between us and the IMF. Our people will say "go to hell with your aid" ${ }^{88}$ As a response to stringent IMF reforms, Suharto threatened to renege on regional free-trade agreements, and shut off Indonesia's banking system from the rest of the region, creating an Islamic banking system with no interest charges ${ }^{89}$ Such changes could precipitate the total collapse of the Indonesian economy, sparking regional instability and a domino effect whereby other countries such as Thailand would seek to renegotiate their own IMF bailout packages. ${ }^{90}$ As a result of Suharto's actions, 'international confidence in the regime, already at an all-time low, simply collapsed ... as Suharto's domestic support began to collapse, his international support evaporated'.$^{91}$

Following the Asian Financial Crisis, domestic support for Suharto's New Order evaporated. Large sections of Indonesian society abandoned Suharto. Despite domestic upheaval, Suharto had himself reappointed president by Indonesia's Consultative Assembly for a seventh term in March 1998. ${ }^{92}$ Suharto then made the decision 'to appoint a new cabinet which included his eldest daughter, a notorious businesswoman, and other cronies'. ${ }^{93}$ Student-led demonstrations against the Indonesian government's handling of the economic crisis began in May 1998. ${ }^{94}$ On 12 May, Indonesian troops fired on students as they returned to their university campus, killing four. The following day, riots broke out in the capital's Chinese commercial centre, with approximately 1200 people killed. ${ }^{95}$ Subsequently, thousands of Chinese families fled the country. As protests grew within Indonesia, plans were made to hold a mass meeting of over one million Indonesian citizens on 20 May 1998. Commander-in-Chief General Wiranto 
threatened to create a 'Tiananmen' tragedy if the meeting were to take place, and plans were subsequently abandoned. ${ }^{96}$ As a result of mass public protests, General Suharto had little option but to resign from office. He did so on 21 May 1998, appointing his Vice President, Bacharuddin Jusuf Habibie, to succeed him. ${ }^{97}$

Political turmoil in Indonesia, followed by Suharto's eventual resignation, led to an increased number of secessionist movements in Indonesia's provinces, including East Timor, Aceh and West Papua. On 6 June 1998, the first public meeting to discuss the future of Timor was convened in Dili. ${ }^{98}$ Some 3,000 people, including all Timorese political factions, attended the meeting. ${ }^{99}$ The following week, a student demonstration attended by more than 3,000 people was held at the University of East Timor. ${ }^{100}$ East Timorese student-led demonstrations were also held at the ministries of Foreign Affairs and Justice in Jakarta. During demonstrations in Dili in June and July 1998, calls for a referendum on independence intensified. ${ }^{101}$ Bishop Belo met with President Habibie to discuss East Timor's future in June 1998. Bishop Belo left the meeting announcing that 'President Habibie had promised ABRI [Armed Forces of the Republic of Indonesia] troops would be removed from East Timor little by little'. ${ }^{102}$ However, it would take significant pressure from external powers before agreement on a referendum would be reached. Analysis of external power interests following the Asian Financial Crisis in 1997 will highlight two important factors: first, as a specific result of the financial crisis, interest convergence between Indonesia, the US and Australia began to decrease; and second, that this decrease in interest convergence led to external powers pressuring President Habibie into holding a referendum on East Timor's independence.

\section{Indonesia - external power interest divergence}

Following the financial crisis of 1997, the US was forced to re-evaluate its relationship with Indonesia. ${ }^{103}$ Despite significant pressure from Congress, which had steadily increased since the Santa Cruz massacre in Dili in 1991, the Clinton administration had continued to supply arms and military training to Indonesia. However, Indonesian domestic and economic instability following the Asian financial crisis had a significant impact on US state interests. A Congressional Research Service (CRS) report, written on 6 February 1998, provides several reasons why the effects of the financial crisis in Indonesia were of interest to the US government. ${ }^{104}$ First, due to the interlinking of 
financial markets, instability in the Asian financial markets might affect US markets. American banks and companies were also significant lenders and/or investors in the region. It was feared that turmoil would affect US imports and exports as well as capital flows and the value of the US dollar, in addition to exposing weaknesses in many regional Asian financial institutions. The crisis had a region-wide effect, spreading to South Korea, Hong Kong and Malaysia, with economic problems also adversely affecting Japan, and potentially spreading to Latin America and the US. The crisis might also impede the progress of trade and investment liberalisation under the World Trade Organisation and the APEC forum.

Ultimately, the US had a 'great interest in a prosperous and stable Indonesia that continue[d] to evolve toward democracy' ${ }^{105}$ By helping Indonesia with its economic recovery, the US could 'foster a broader economic recovery in Asia'. ${ }^{106}$ Indonesia was also important to the US in terms of Asian security, largely because the archipelago 'sits astride vital sea lanes through which 40 percent of the world's shipping passes, including 80 percent of Japan's oil supply and 70 percent of South Korea's'. ${ }^{107}$ By offering assistance to Indonesia, the US could 'help Indonesians emerge from their crisis and perhaps build the world's third-largest democracy. An economically reformed and democratic Indonesia would make a worthy strategic partner for the US in Asia'. ${ }^{108}$

Suharto's resistance to the IMF's economic aid and reform package was particularly disconcerting for the US, considering its interests in seeing a stable and prosperous Indonesia in Southeast Asia. As a response, Washington pushed Suharto to accept the IMF reform package. By March 1998, the US stated it would 'refuse dispersal of IMF loans to Indonesia without appropriate progress on dealing with monopolies, subsidies, monetary policies and [its] approach to the financial system'. ${ }^{109}$ It is therefore apparent that, by early 1998, the US had taken a stronger stance against Indonesia. Whereas Indonesia was once a vital component in Washington's regional defence against Cold War threats, it now constituted a threat by itself, capable of destabilising the region and its economy.

When President Habibie replaced General Suharto in May 1998, Habibie inherited an economy in vital need of recovery. The US threat to refuse dispersal of IMF loans, if actualized, would put Jakarta in an intolerable situation. Like Suharto, Habibie had been in support of East Timor's integration with Indonesia. However, occupation of East Timor was costing the Indonesian government approximately US\$1 million per day in $1998 .{ }^{110}$ In the post financial crisis environment, this figure was unsustainable. The US also began 
to press Indonesia on its human rights abuses in East Timor, urging UN-sponsored talks between the two parties aimed at settling East Timor's political status. ${ }^{111}$ In June 1998, less than three weeks after the resignation of Suharto and with external power support diminishing, President Habibie announced that a 'new status for East Timor should be contemplated'. ${ }^{112}$ In particular, Habibie announced that 'he was willing to consider autonomy for East Timor in exchange for international recognition of Indonesian sovereignty'. ${ }^{113}$

Habibie's announcement was closely followed by US Senate Resolution 237, which was unanimously adopted on 10 July $1998 .{ }^{114}$ In this resolution, the Senate stated that President Clinton should, 'encourage the new political leadership in Indonesia to promote and protect the human rights and fundamental freedoms of all the people of Indonesia and East Timor ... [and] support an internationally supervised referendum on self-determination'. ${ }^{115}$ Clearly for the US, the Asian financial crisis and Suharto's subsequent resignation from power were a turning point. Congress had been pushing the President to take action with regard to Indonesia's human rights abuses in East Timor since 1991. The Senate increased this demand following Suharto's resignation. This pressure from Congress, coupled with Washington's desire to safeguard economic and security interests, ultimately led President Clinton to adopt a new policy with regard to Jakarta. The US would refuse dispersal of much-needed aid to Indonesia, unless Habibie allowed a referendum on self-determination in East Timor. This revaluation of the US-Indonesia relationship meant Indonesian occupation of East Timor lacked the international support it once had. Holding a fragile grip on power, and in need of continued foreign economic aid, Habibie came under pressure from the US, which saw an opportunity to push Indonesia towards a change in its East Timor policy.

\section{Australia interest divergence}

Developments in Indonesia and changes in the US-Indonesia relationship were being closely followed in Canberra. The Howard government had adopted a different stance towards Asia since gaining power in 1996. According to this view, engagement with Asia would only be pursued if in the national interest, and if it did not involve the abandonment of other values such as the international rule of law. ${ }^{116}$ Prior to 1997, high levels of import and export trade with Indonesia, coupled with high foreign direct investment, meant that it remained in 
the national interest to foster good relations with Indonesia. However, the regional financial crisis overturned the long-held foreign policy assumption that a prosperous Asia would bring Australia into its economic orbit. ${ }^{117}$ As investments were threatened, regional instability increased, and the crisis 'threatened to undermine Canberra's attempts at fostering regional organisations.'. ${ }^{118}$

Like the US, the Australian government pushed Indonesia to implement IMF reforms. Refusal to accept reforms could 'lead to instability in the region and precipitate a complete economic catastrophe'. ${ }^{119}$ Australia was also concerned about the change of leadership in Indonesia. According to Hugh White, Deputy Secretary in the Australian Department of Defence, Canberra believed that Dr Habibie 'appeared erratic and weak ... his relationship with TNI [Indonesia's National Armed Forces] was especially problematic ... even if TNI did not seize power directly, it seemed likely to be a critical player in Indonesia's political evolution' ${ }^{120}$ It was therefore determined that 'Australia's priorities in the post-Suharto era was to support Indonesia's democratic transformation, and to sustain a good relationship with TNI'. ${ }^{121}$

Suharto's departure, precipitated by the financial crisis, also offered Australia an opportunity to address its East Timor policy. ${ }^{122}$ In May 1998, the Australian Labour opposition party debated the question of East Timor, adopting the policy that the East Timorese had a right to self-determination. ${ }^{123}$ This was one of the first times a government party had challenged the prevailing consensus that Indonesia had sovereignty over East Timor. ${ }^{124}$ At the same time, links between the Australian Defence Force and Indonesia's Kopassus force were suspended, after the latter's involvement in violence against Indonesian pro-democracy protestors and demonstrators at the time of Suharto's resignation. ${ }^{125}$ In October 1998, following an Australian federal election, Australian Foreign Minister Alexander Downer initiated a re-examination of Australia's East Timor policy. In November 1998, parliamentary sessions held by the Australian Department of Foreign Affairs and Trade granted the motion adopted by the federal Senate to lead a review of the Timor issue. During this review, 'the opinions of refugee and political leaders were sought on the future shape of an autonomous or independent East Timor, and on what support would be needed if the territory was ever to become self-sufficient'. ${ }^{126}$ The review found that the East Timorese would not accept any connection with Indonesia without a referendum. As such, the decision was taken that Canberra should seek to influence policy in Jakarta more directly. ${ }^{127}$ 


\section{The Howard letter}

Australian Prime Minister John Howard took Canberra's first step to influence policy in Jakarta in December 1998. By this time, it had become apparent to the Howard government that the status quo Australia and Indonesia had maintained with regard to their East Timor policy was no longer sustainable. As such, Howard wrote to Habibie, suggesting East Timor be granted autonomy and the right to self-determination. On the surface, this appeared to constitute a total policy reversal by Canberra. However, this is not the case. While Howard did recommend autonomy for East Timor, this was to be an extensive period of autonomy of up to ten years, before the holding of a referendum. ${ }^{128}$ In addition to this, Howard expressed his 'Government's preference for autonomy within Indonesia rather than independence'. ${ }^{29}$ As such, the Howard letter actually demonstrated the continuity of Australia's foreign policy with relation to Indonesia and East Timor. Primarily, the letter intended to 'encourage Indonesia to find a longterm and incremental solution to the problem of East Timor'. ${ }^{130}$

For the Australian government, East Timor autonomy within Indonesia was preferable to independence for two reasons. First, there was a growing concern in Canberra that 'an independent East Timor would be economically unviable and politically unstable, and thus a liability to regional security for which Australia would have to take prime responsibility'. ${ }^{131}$ Second, East Timor autonomy within Indonesia would prevent Indonesian Balkanisation. By 1997, Indonesia was still described as 'a key determinant of Australia's security in the years ahead'. ${ }^{132}$ Australian defence analyst Paul Dibb confirmed that 'a unified Indonesia is vital to Australia's national interest' and that Balkanisation is 'something we must make absolutely sure doesn't happen'. ${ }^{133}$ Both Richard Woolcott and Alexander Downer echoed this view, with the former claiming that 'it is foolish to suggest the fragmentation of Indonesia into a number of independent states need not concern Australia'. ${ }^{134}$

What the Howard government could not predict was Habibie's response to the letter, which inadvertently 'generated outcomes that it had specifically sought to avoid'. ${ }^{135}$ For Jakarta, the Howard letter 'although couched in cautious, diplomatic language ... constituted an unmistakable shift in policy as it suggested acceptance of the idea of self-determination for the people of East Timor, albeit after a delay of time'. ${ }^{136}$ According to Indonesia's Foreign Minister Ali Alatas, Habibie was 'visibly agitated with the implications of the letter', rejecting the idea that Indonesia could continue to fund East Timor. ${ }^{137}$ Habibie 
preferred rapid action to resolve the issue so as not to play 'rich uncle' to East Timor, ${ }^{138}$ or to 'leave a time bomb' for his successor. ${ }^{139}$ Clearly, financial pressures and constraints were forcing Habibie's hand. A lengthy period of East Timor autonomy within Indonesia, as preferred by Australia, was not a viable option for Jakarta at that time. A quick act of self-determination for East Timor was 'the exact opposite of what the Howard letter sought to achieve'. ${ }^{140}$ Habibie's proposal 'was a bid to win the support of the international community, whose backing Indonesia badly needed if it was to rebound from the financial crisis' ${ }^{141}$

Habibie's decision to move quickly presented Australia with a fait accompli, giving the government very little option but to go along with it. ${ }^{142}$ A senior Australian diplomat in the Jakarta embassy 'was instructed to leak the [Howard] letter to an Australian newspaper reporter based in Jakarta'. ${ }^{143}$ Alexander Downer then called a press conference 'to announce what he called an historic policy shift' with regard to Australia's East Timor policy. ${ }^{144}$ In what was essentially a 'damage-limitation exercise' by Canberra, following nearly a quarter of a century of support for Indonesia's East Timor policy, the Howard government recognized East Timorese right to self-determination on 5 January 1999. ${ }^{145}$ For the Habibie government, Australia's announcement was 'the final straw', and contributed to a dramatic announcement from Jakarta that a referendum to determine East Timor independence would be held in August 1999. ${ }^{146}$

\section{ASEAN institutional cohesion}

Notably absent from the foregoing analysis is the role of the ASEAN states, who maintained the same policy regarding East Timor in 1999 as they had after Indonesia's initial invasion in 1975. The ASEAN states 'had little to say publicly' on the matter, refraining from discussing the topic and maintaining silent support for Indonesia. ${ }^{147}$ In April 1999, Rodolfo Severino Jr, the Secretary General of ASEAN, stated that the problem of East Timor 'was for the Indonesians and the international community to resolve'. ${ }^{148}$

Indonesian stability was vital for ASEAN state security. In a May 1999 meeting, convened at the Philippine presidential palace by members of President Joseph Estrada's cabinet, fears were expressed at the 'prospect of a political or social disintegration in Indonesia [which] would threaten not only the security of Southeast Asia but also the unity of ASEAN'. ${ }^{149}$ A disintegrating Indonesia could herald the end of the Association. There also remained concerns over the 
possibility that 'separatist groups elsewhere in Southeast Asia might draw succour and inspiration from FRETILIN's success' ${ }^{150}$ Separatist movements could damage domestic stability, and allow external powers a foothold in the region. For the Southeast Asian states, solidarity with Indonesia was vital. Cambodian officials argued that 'the important thing is we need to have good cooperation with Jakarta. We don't have any clear position [on East Timor] ... because it is the internal affair of Indonesia'. ${ }^{151}$ A Philippine diplomat expressed similar sentiments, confirming that 'the Philippines would not be risking a long-time ally on any one issue'. ${ }^{152}$

At an APEC meeting held on 9 September 1999, the ASEAN states were reported to be 'furious that APEC forum organizers had allowed East Timor talks to side-track the trade summit'. ${ }^{153}$ Senior Thai Foreign Ministry official Kopsak Chutikul confirmed that 'no ASEAN countries will attend [the East Timor talks] because it is a non-APEC issue'. ${ }^{154}$ Similarly, Singapore Prime Minister Goh Chok Tong stated that ASEAN 'had not met to discuss East Timor', ${ }^{155}$ with Thai Foreign Minister Surin Pitsuwan arguing that 'ASEAN should contribute [to the East Timor crisis] in a way that we think is effective and appropriate. At this point, we think through the UN process is most effective and most appropriate. Let us keep it at that level'. ${ }^{156}$ It is apparent that if there was to be a resolution to the matter of Timorese independence, it was not going to be orchestrated by ASEAN.

\section{East Timor's vote for independence}

On 27 January 1999, Indonesia's Foreign Minister Ali Alatas announced that Indonesia would allow a referendum to determine East Timor's political future. If the majority of East Timorese rejected autonomy in favour of independence in a 'process of consultation', Indonesia would grant that independence. ${ }^{157}$ However, not all elements within the Indonesian government approved of Habibie's decision to allow a referendum. This is especially true of Indonesia's National Armed Forces, the TNI, formerly the ABRI, and their commander-in-chief General Wiranto. Wiranto disagreed with Habibie's East Timor decision, and like most of the military 'did not regard the political aspirations of the East Timorese as legitimate'. ${ }^{158}$ In order to get the military's consent for an August referendum, conditions were laid down 'that there be no revision of the historical judgment that the army's conduct of the intervention was beyond reproach, and that its casualties were not in vain'. ${ }^{159}$ 


\section{UN-brokered negotiations: United Nations mission in East Timor}

Consultations between Indonesia and East Timor's former colonial power Portugal began with UN-brokered talks for popular consultations. Although an initial draft plan was produced, 'differences on provisions for a referendum, a future constitution, and an interim UN presence prevented the principals from signing the document'. ${ }^{160}$ $\mathrm{UN}$-assisted negotiations continued between Indonesia and Portugal in New York in March 1999. On 12 March, UN Secretary General Kofi Annan announced that the parties had agreed upon a method of direct ballot, to ascertain whether the people of East Timor accepted or rejected a proposal for autonomy. It was agreed that a UN presence would assist the ballot. As the UN pushed Indonesia and Portugal towards finalized negotiations, the situation in East Timor was gradually deteriorating. In March and April 1999, 'militia groups backed by the TNI and police forces began to assault and detain known advocates of independence, and to burn down the houses of those thought to be supporting them'. ${ }^{161}$ On 6 April, militia members killed at least 50 East Timorese who had taken refuge in a Catholic church in Liquiçá. ${ }^{162}$ Present at the massacre were TNI troops and local police, which not only failed to prevent the attack, but - which many claim - helped to organize it and carry it out. ${ }^{163}$

Amidst reports of violence in East Timor, the UN pushed Indonesia and Portugal to reach a conclusion on negotiations. These efforts culminated in an agreement signed by the two governments on 5 May 1999, entrusting the UN Secretary General with 'the organisation and conduct of a popular consultation for the purpose of ascertaining whether the East Timorese people ... accept or reject a proposed constitutional framework providing for a special autonomy for East Timor within the unitary Republic of Indonesia'. ${ }^{164}$ Under Article 5 of the Agreement, if the people of East Timor approved the proposal for special autonomy, the Indonesian government would initiate the constitutional measures required for the implementation of the autonomy framework. The question of East Timor would also be removed from the UN Security Council and General Assembly agenda. Under Article 6 of the Agreement, should the people of East Timor reject the proposal for special autonomy, the Indonesian government would take the necessary steps to terminate Indonesia's links with East Timor. The governments of Indonesia and Portugal would also agree with the Secretary General on arrangements for a peaceful and orderly transfer of authority in East Timor to the UN, which would begin a process of enabling East Timor to transition to independence. 
Under Article 7 of the Agreement, the Secretary General noted that 'it is foreseen that the United Nations will maintain an adequate presence in East Timor during the interim period'. 165 The Agreement stipulated that the ballot would take place on 9 August 1999, and that the Indonesian authorities would have the responsibility for maintaining law and order. Upon signature of the agreement, the UN would deploy personnel to East Timor, adequate for the execution of the various phases of the consultation process. This agreement formed the basis of the United Nations Mission in East Timor (UNAMET). Authorized by the UNSC on 11 June 1999, the role of UNAMET was to organize and conduct a popular consultation. ${ }^{166}$

The UNSC authorized the deployment of up to 280 civilian police officers in East Timor, to act as advisors to the Indonesian police and to escort the ballot papers and boxes from the polling sites. ${ }^{167}$ It was a contentious decision to allow the Indonesian authorities responsibility for controlling law and order during the ballot. Indonesia made it clear that it would not allow East Timor security to be an international responsibility. Habibie informed Howard that if a peacekeeping force 'was imposed on Indonesia then it would abandon East Timor and the ballot and unilaterally withdraw'. ${ }^{168}$ It was implicit that 'had Habibie accepted a pre-ballot PKF [peacekeeping force], this might have precipitated a civil-military showdown and posed the grave risk of a TNI coup'. ${ }^{169}$ However, some commentators asserted that an independent peacekeeping force should be put in place for the ballot, because 'referendums have a poor record as peace-building mechanisms in conflict situations, because they are a "zero-sum game"; that is, there is always a big winner and a big loser, and loss of face is inevitable'. ${ }^{170}$ The idea that East Timor may require peacekeepers was steadfastly refuted by the US government, which was worried that pressure for a peacekeeping force might threaten the vote itself. ${ }^{171}$ It was also refuted by Canberra, which did not want to endanger Australia's strategic objectives by precipitating a potential TNI coup. ${ }^{172}$

\section{TNI militia violence before and after the vote}

As UNAMET staff arrived in East Timor and began to witness the level of violence being perpetrated by the TNI and militia, many argued strongly against proceeding with an August ballot. Instead, they suggested a postponement pending a significant improvement in the security situation. ${ }^{173}$ However, external powers were concerned that, given more time, Habibie may change his mind about the ballot. 
The domestic situation in Indonesia also remained unstable. In June 1999, elections were held in Indonesia for the People's Representative Council. Habibie's party came second to Megawati Sukarnoputri, who had openly criticized Habibie's actions in relation to East Timor. ${ }^{174}$ Indonesia's People's Consultative Assembly was due to meet on 29 August to select a new president, with Sukarnoputri likely to be chosen. This put further pressure on the timing of the vote.

Despite the presence of UNAMET in the region, pro-Indonesia militias continued to terrorize the inhabitants of East Timor in the lead-up to the ballot, hoping to affect its final outcome. UNAMET observers witnessed TNI officers training and conducting joint operations with militia groups. ${ }^{175}$ Militias were also seen carrying firearms and wearing new TNI uniforms. The Indonesian police routinely failed to investigate militia violence, and informed UN officers that they were constrained from doing so by the TNI. ${ }^{176}$ This was a fact already known to the Australian government, whose intelligence community 'concluded that ABRI had armed various prointegrationist militia groups and was planning to use them against East Timorese who supported moves towards independence'. ${ }^{177}$ Australia remained convinced however that 'Canberra's special relationship with Jakarta ... would ensure that the Indonesian authorities remained both frank and responsive in their dealings with Canberra over East Timor'. ${ }^{178}$ Australia maintained this stance despite the continued evidence of Indonesian complicity in militia violence.

Within East Timor, voter registration began on 16 July. This coincided with a lull in militia violence, which supported what some within UNAMET and the UN believed was a 'genuine change in government and TNI policy' brought about by 'concerted international political pressure at the beginning of July'. ${ }^{179}$ The high East Timorese turnout for registration supported this view, and UNAMET moved ahead with the second stage of voter registration on 26 July. However, this second stage was more volatile, involving politically motivated violence directed against civilians, and serious militia attacks on UNAMET staff. On the morning prior to the ballot, a public ceremony at UNAMET headquarters was held between FALINTIL and the militias. It was announced that an agreement had been reached between the two parties, which promised 'to refrain from recourse to violence, and abide by the outcome of the vote'. ${ }^{180}$ Despite this agreement, TNI commander Colonel Tono Suratman warned that 'if the pro-independents do win ... all will be destroyed $\ldots$ it will be worse than 23 years ago' ${ }^{181}$

On the day of the Timorese independence ballot, 98.6 percent of the enrolled voters cast their votes. ${ }^{182}$ Of that 98.6 percent, 
78.5 percent chose in favour of independence, effectively ending Indonesia's claim to the territory. Before the results were announced, militia violence began to escalate, with violence aimed at UNAMET staff and East Timorese civilians. As the security situation in certain Timorese districts worsened, UNAMET staff had to evacuate to Dili on the morning of 3 September. The result of the ballot was officially announced on 4 September 1999. Following the results, a three-week campaign named Operation Clean Sweep began, in which Indonesian armed forces and locally organized militia undertook a scorched earth policy, executing hundreds, possibly thousands of East Timorese. ${ }^{183}$ Over three-quarters of East Timor's population were forcibly displaced, and over 70 percent of the infrastructure was destroyed. ${ }^{184}$ Between 5 September and 14 September, the UNAMET compound in Dili came under siege, preventing UN staff from stopping the violence, and risking the lives of several hundred staff. ${ }^{185}$ Indonesian authorities claimed that the militias 'had formed spontaneously in response to provocation by pro-independence activists'. ${ }^{186}$ However, all the evidence demonstrates that 'the militias were mobilized, trained, supplied and backed by Indonesian authorities'. ${ }^{187}$

\section{Calls for external intervention in East Timor}

As violence continued to spread through East Timor, UNAMET was forced to withdraw its personnel from the region. By midday on 10 September, 444 international and local UN staff had been airlifted to safety in Darwin, leaving 81 international staff inside the Dili compound. ${ }^{188}$ With violence raging in East Timor, President Habibie came under intense pressure from the UN to allow a peacekeeping coalition to intervene in the area. Habibie acknowledged that international assistance might be required to restore peace, ${ }^{189}$ and on 6 September, the Secretary General asked Prime Minister Howard to lead a multinational intervention force in East Timor. ${ }^{190}$ The UN Secretary General was adamant that Indonesian 'claims of national sovereignty must not be allowed to stand in the way of effective international action in defence of human rights'. ${ }^{191}$

\section{US response to the humanitarian crisis}

It took several days of pressure by the UN Secretary General before certain states changed their posture towards intervention in East 
Timor. External powers, specifically the US, continued to argue that Indonesian armed forces should be in charge of the restoration of power in East Timor, and called upon Indonesian leaders to control the violence. ${ }^{192}$ The US resisted an international peacekeeping force for days after violence erupted, indicating that it wanted Australia to take the leading role in any East Timor intervention. ${ }^{193}$ A number of reasons for US delays in supporting a peacekeeping force are plausible. First, there was a reluctance to fund the endeavour. ${ }^{194}$ Second, the US had placed strict conditions on its support for peacekeeping missions following the deaths of US soldiers in Somalia in 1993.

By 8 September, the US opinion regarding an East Timor peacekeeping force had started to shift. At this time, commander-inchief of the US forces in the Pacific, Admiral Dennis Blair, met with General Wiranto in Jakarta and told him 'that military ties between the US and Indonesia were to be suspended'. ${ }^{195}$ Additionally, in advance of an upcoming APEC meeting, President Clinton stated that 'if Indonesia does not end the violence, it must invite - it must invite the international community to assist in restoring security ... it would be a pity if the Indonesian recovery was crashed by this'. ${ }^{196}$ Nor was this an empty threat. The US told Indonesian officials that the World Bank would withhold future crisis funding if security was not returned to East Timor. The IMF also suspended a visit to Jakarta to discuss financial crisis aid. On 12 September, at a scheduled APEC meeting between Asian leaders and the US, President Clinton stated that 'the Indonesian military has aided and abetted militia violence in East Timor ... we are ready to support an effort led by Australia to mobilize a multinational force to help bring security to East Timor under UN auspices'. ${ }^{197}$

\section{Australian response to the humanitarian crisis}

By mid-September the Australian government had also come to the conclusion that the benefits of intervention now outweighed the costs. Initially, Australia had been reluctant to endorse a peacekeeping force in East Timor, since to do so 'would have been to effectively renounce support for Indonesian sovereignty of East Timor' ${ }^{198}$ Despite evidence of violence in East Timor, Australia continued to believe that 'pressure from interested members of the international community, including Australia, would lead to an improvement in the security situation'. ${ }^{199}$ The government had been under mounting pressure to take action in East Timor from domestic movements and NGOs, ${ }^{200}$ which had been particularly vocal on the topic of Timorese autonomy. ${ }^{201}$ These groups 
had been active since Indonesia's initial invasion of the territory, and had stepped up domestic pressure in the period following the Santa Cruz massacre in 1991.

However, evidence suggests that domestic pressures did not play a key role in Canberra's decision-making regarding Indonesia and East Timor. This was evident in 1995, when the Australian government signed the secret security agreement with the Indonesian government, without allowing the public to participate in the decision-making process. The Jakarta lobby argued that this was 'a fantastic slap in the face for the anti-Indonesian protest groups ... it declares definitively that the protest groups cannot set the agenda in the Australia-Indonesia relationship'. ${ }^{202}$ The timing of Australia's decision to intervene in East Timor suggests that the Howard government took a similar stance to domestic movements. Despite a long period of domestic pressure, Australia did not decide to intervene in East Timor until 7 September, one day after the UN Secretary General requested that Australia lead a multinational intervention force. ${ }^{203}$ This suggests that popular pressure was not the deciding factor in Australia's decision, and that instead 'the government's attention shifted to securing Australia's interests in East Timor directly'. ${ }^{204}$ Hugh White confirmed that 'if East Timor proves to be a viable country and a reasonable neighbour, with stable internal politics and responsible international relationships, then Australia's original concerns about the threats to regional stability posed by a non-viable East Timor will have proved unfounded'. ${ }^{205}$

\section{Habibie rejects a peacekeeping coalition}

Faced with mounting UN and external power pressure to accept a peacekeeping coalition in East Timor, President Habibie remained adamantly opposed to intervention. The Indonesian government stated that the presence of international forces 'would represent an unacceptable violation of Indonesian sovereignty, and if foreign troops tried to land without prior Indonesian agreement, they would have to fight their way ashore'. ${ }^{206}$ Despite the 'dubious legal basis' for Indonesia's sovereignty claim, both Australia and the US respected Indonesian wishes at that time. ${ }^{207} \mathrm{~A}$ number of important factors conspired to change Indonesia's position: the loss of external power support; the loss of institutional financial assistance; the suspension of British military supplies on 13 September; and a general arms boycott lodged by the European Union. The culmination of these pressures left Habibie in an untenable situation. 
The President of the World Bank wrote to Habibie in early September, stating the belief that Indonesia [must] 'act swiftly to restore order'. ${ }^{208}$ Following a threat of economic aid suspension, the World Bank announced its decision to freeze $\$ 300$ million of Indonesian economic aid recovery. Similarly, the IMF informed Indonesia of its decision to halt the disbursement of some $\$ 460$ million. ${ }^{209}$ Heavily reliant upon foreign economic and military aid, Habibie met with his military officials on 12 September to discuss the crisis in East Timor. This meeting came the same day as President Clinton's speech at APEC, where it was announced that the US would support an effort to mobilize a multinational force in East Timor. It also came the day after an open debate was held on East Timor in the UNSC, where some 50 states spoke in favour of urgent international intervention in East Timor. With the support of General Wiranto, President Habibie reluctantly 'proposed that Indonesia should now permit an international force to assist in restoring order in East Timor'. ${ }^{210}$ The Indonesian view was relayed to the UN Secretary General, effectively ending the crisis by sanctioning a UN-sponsored peacekeeping force to enter East Timor.

\section{Indonesian failure to resist sovereignty violation}

On 15 September 1999, the UNSC adopted Resolution 1264. Invoking Chapter VII of the UN Charter, the Resolution expressed concern at the 'widespread and flagrant violations of international humanitarian and human rights law'. ${ }^{211}$ As such, the Resolution authorized 'the establishment of a multinational force under a unified command structure'. ${ }^{212}$ The remit of the force was 'to restore peace and security in East Timor, to protect and support UNAMET in carrying out its tasks and, within force capabilities, to facilitate humanitarian assistance operations'. ${ }^{213}$ The International Force for East Timor (INTERFET), established under an Australian command structure, was given the authority to use all necessary means to restore security in East Timor. The multinational peacekeeping taskforce first entered East Timor on 21 September 1999, less than one week after the Security Council Resolution. INTERFET's task was to address the humanitarian crisis in East Timor, until a more permanent UN peacekeeping force could be assembled. Australian Foreign Minister Alexander Downer made concerted efforts to encourage troops from different countries to join this 'coalition of the willing'. Despite this, Australian personnel comprised the core of the peacekeeping taskforce. ${ }^{214}$ Hugh White summarized Canberra's decision to lead the 
INTERFET force, stating that 'there was a sense that if Australia didn't lead, no one else would'. ${ }^{215}$

For the Australian government, returning East Timorese stability was vital 'to avoid having yet another weak and fragile state in what is already a difficult neighbourhood'. ${ }^{216}$ Australian Prime Minister John Howard cemented his beliefs in the 'Howard Doctrine', which he announced the same week that INTERFET entered East Timor. Howard's conviction was that, post-Timor, Australia would seek to upgrade its defence forces and embrace a new role as the US' peacekeeping 'deputy' in Asia, with involvement in East Timor helping to 'cement Australia's place in the region'. ${ }^{217}$ Having reinforced Canberra's role as lead command of the peacekeeping force, INTERFET began to round up militias in East Timor, in some cases killing them. ${ }^{218}$ Whilst this approach elicited protests from some within Indonesia, INTERFET met with very little resistance, either from the militias or the TNI. ${ }^{219} \mathrm{~A}$ measure of security was restored to East Timor relatively quickly, with INTERFET taking till 16 November to secure the region. Despite this success, INTERFET was not 'intended or equipped to resolve the many problems of administration or reconstruction'. ${ }^{220}$ As such, UNAMET re-established a presence in the region from 29 September, until a more comprehensive effort could be authorized and mobilized.

Despite Canberra explicitly seeking a Southeast Asian contingent for INTERFET, the states of ASEAN were notably reluctant to take part in an East Timor peacekeeping force. As Lee Kuan Yew confirmed, intervention in East Timor was 'a task no country in the region would have undertaken'. ${ }^{221}$ While Lee acknowledged that 'it did not make sense' for the TNI to devastate East Timor, he stated that 'many things that did not make sense had happened, which is why Singapore, like the others in ASEAN, had stayed out of the East Timor issue'. ${ }^{222}$ The ASEAN states were particularly reluctant to intervene in East Timor without prior permission from Indonesia, and were also uncomfortable with the unprecedented power afforded to INTERFET. As Singapore Prime Minister Goh Chok Tong argued, East Timor 'was not a problem created by ASEAN, it was and is an international problem that remains an issue with the United Nations. It never started off as an ASEAN problem'. ${ }^{223}$

These were sentiments felt by the majority of ASEAN states. The member states were, 'suspicious of Western attempts to internationalize the dispute [and concerned] ... that East Timor could set a precedent for Western interference in the internal affairs of other member states using the norm of humanitarian intervention as justification'. ${ }^{224}$ Prime Minister Mahathir of Malaysia was particularly outspoken on the topic of Western 
interference in the internal affairs of states. Of specific concern was the implication that in times of humanitarian crisis, the use of military force against a sovereign state could be determined and sanctioned by a concert of Western states. ${ }^{25}$ This concern was echoed throughout Southeast Asia and the Third World, where states worried that humanitarian intervention could allow the West 'to call into question the legitimacy of governments and regimes not of their liking'. ${ }^{226}$

Blaming the US and UN for the East Timor crisis, Mahathir argued that President Habibie had been, 'pressured to allow an act of selfdetermination even though many East Timorese had reconciled themselves to integration with Indonesia'. ${ }^{227}$ According to Mahathir, there had been 'no killings' before the ballot, and pro-Indonesia Timorese had felt 'cheated' by the quick vote and 'responded in the only way they knew how'. ${ }^{228}$ Mahathir also expressed the view that 'the West would like to see Indonesia broken up into smaller countries' with Australia 'the main beneficiary'. ${ }^{229}$ Coupled with these concerns were a number of more pragmatic considerations related to sending troops to take part in INTERFET. Some ASEAN countries worried about the potential consequences for ASEAN troops if they were to exchange fire with Indonesian troops or Indonesian-backed militias. ${ }^{230}$ Others were concerned about the expense of participating in an intervention, with some making participation in INTERFET conditional on financial support from Australia and Japan. ${ }^{231}$

Indonesia was suspicious of Australia's intentions in the region after Canberra's policy shift on East Timor's right to self-determination. These suspicions intensified after Australia agreed to lead the INTERFET force into East Timor. The Indonesians tore up the 1995 security pact signed with Australia on 16 September 1999, the day after the UN Security Council approved INTERFET. ${ }^{232}$ The 'Howard Doctrine' in particular drew angry reactions from many within Southeast Asia. This can best be summarized by Malaysian Democratic Action Party Secretary General Lim King Siang, who argued that, 'Asia does not want, nor has it recognized, the US as the policeman of the world, what's more, one needing a deputy'. ${ }^{233}$ For Jakarta, Howard's remarks acted as a potential agent of interference in Indonesia's internal affairs. ${ }^{234}$

\section{Indonesia requests an ASEAN contingent in INTERFET}

Canberra's role in INTERFET led to 'assaults on Australian personnel and property within Indonesia, as Jakarta's former ally was considered 
to have its own designs on East Timor's resources'. ${ }^{235}$ Ultimately, Indonesia's perception of its 'nation's humiliation at the white hands of Canberra', meant that it sought to minimize Australia's influence in East Timor. ${ }^{236}$ It did so by expressly requesting an ASEAN presence within INTERFET. Habibie approached Thailand initially, requesting an ASEAN contribution to the force. This left ASEAN with little option but to engage with the INTERFET force. Not to do so would sour relations with Indonesia and invite international condemnation. In addition to a Thai contingent to INTERFET, Malaysia, Singapore and the Philippines also agreed to contribute troops to the multinational force.

As ASEAN troops prepared for deployment, Mahathir met with the UN Secretary General to discuss a scaling back of Australian troops within INTERFET, stating that 'there are other ways of solving problems besides pointing guns at people'. ${ }^{237}$ Similarly, Thailand advocated restraint from the Australian troops, suggesting that Asian troops would be more 'gentle'. ${ }^{238}$ Canberra confirmed that it wanted to scale back Australian troops and include more troops from ASEAN. However, this could not be implemented because ASEAN countries were weeks away from deployment and were unwilling to foot the bill for a lengthy involvement. ${ }^{239}$ ASEAN's eventual contribution to INTERFET numbered approximately 2500 of the 9900 force. ${ }^{240}$ Thai troops formed the second largest contingent to the force of about 1500 troops, including the force's deputy-commander. ${ }^{241}$ In an effort to maintain good relations with Indonesia, the Philippine government declared its official designation as a 'Humanitarian task force', sending only non-combatant forces of engineering and medical units. ${ }^{242}$

Despite the eventual contribution to INTERFET, ASEAN's slow response to the crisis raised serious questions regarding the Association's ability to respond to regional conflicts. Without Western intervention, it is highly unlikely the East Timor crisis would have been resolved. This enhanced the view held by many in the West that ASEAN was "chronically incapable of taking meaningful action even when its own interests are directly engaged'. ${ }^{243}$ Evidence suggests that the ASEAN states learnt very little from the crisis in East Timor. In a July 2000 ASEAN Joint Communiqué, ASEAN foreign ministers 'commended Indonesia for all its efforts in resolving the East Timor issue'. ${ }^{244}$ This led at least one commentator to argue that 'there was no suggestion of lessons learned or mistakes to be avoided'. ${ }^{245}$ 


\section{East Timor's formal independence}

On 25 October 1999, the UNSC established a United Nations Transitional Administration in East Timor (UNTAET), which was given overall responsibility for administration of the country. ${ }^{246}$ East Timor became formally independent on 20 May 2002, at which time the state was renamed Timor-Leste. Upon independence, UNTAET ended, to be replaced by the UN Mission of Support in East Timor (UNMISET), established to provide assistance to core administrative structures and to provide interim law enforcement. Although initially established for a period of 12 months, the mandate was extended until 20 May 2005. At this time, all UN personnel left the region. However, Timor-Leste remained weak and vulnerable, with many important nation-building tasks still uncompleted. Timor-Leste descended into internal and factional conflict in 2006, necessitating an International Stabilisation Force (ISF), which was unable to leave the country until 22 November 2012. Timor-Leste remains a vulnerable state, still attempting to grapple with independence.

\section{INTERFET as a violation of Indonesian sovereignty}

Did intervention in East Timor by way of a UN-mandated peacekeeping force constitute a violation of Indonesian sovereignty? There are two potential arguments against intervention in East Timor constituting a breach of Indonesian sovereignty. First, because Indonesia's claim to sovereignty in East Timor was not recognized by the UN, intervention by a peacekeeping force could not constitute a breach of Indonesian sovereignty. Second, Indonesia's sovereignty could not have been violated, because Indonesia agreed to the peacekeeping force entering East Timor.

\section{UN recognition of Indonesia's claim to sovereignty}

With respect to the first argument, there are a number of important factors to consider. First, Indonesia clearly believed that it exercized sovereignty over East Timor, making it clear that discussion of East Timor would represent an unacceptable violation of Indonesian sovereignty. Second, and related to the first, Indonesia's claim of sovereignty over East Timor was recognized by members of the 
international community. All ASEAN states supported Indonesia's East Timor policy, believing the matter to be an internal affair of Indonesia. This provided strong regional support for Indonesia's claim of sovereignty over East Timor. External powers also recognized Indonesian sovereignty over East Timor. Australia acknowledged Indonesia's sovereignty over the territory when it signed the Timor Gap 'Zone of Cooperation Agreement'. Evidence suggests that the US also supported Indonesia's claims over East Timor. The US Ambassador to Jakarta, Mr Robert Barry, stated that the US government had from the start accepted East Timor's incorporation into Indonesia. ${ }^{247}$ The US also sought to frustrate UN attempts to resolve the East Timor issue post1975, and helped to keep the Timor issue off the international agenda. Third, members of the international community made it clear that they would not move ahead with an intervention force in East Timor without Indonesian approval; the implication being that to intervene without Indonesian approval would constitute a breach of Indonesia's rights. Despite a lack of UN recognition, Indonesia, ASEAN and the international community recognized Indonesian sovereignty in East Timor. For Indonesia, this validated its occupation of the territory.

\section{Indonesia's agreement to a peacekeeping force}

A basic principle of UN peacekeeping is that 'operations are deployed with the consent of the main parties to the conflict'. ${ }^{248}$ This is a legal necessity, so as not to violate Article 2(7) of the UN Charter, which states that the UN has no authority 'to intervene in matters which are essentially within the domestic jurisdiction of any state'. ${ }^{249}$ Thus, it might be surmised that Indonesia's consent to a UN peacekeeping force in East Timor legitimized intervention. However, the conditions under which this consent was given should be brought into question. According to Krasner, violations of sovereignty can occur through coercion or imposition. ${ }^{250}$ In situations of coercion, there is the threat, 'to impose sanctions on another if the target ruler does not alter his or her policies. The target can reject these demands, in which case it suffers sanctions, or accept them. In either case the target is worse off' ${ }^{251}$ Violation through imposition 'involves a situation in which the target has no choice but to accept the demands of the initiator ... the target is so weak that it cannot effectively resist' ${ }^{252}$ Coercion and imposition violate state sovereignty because a state would never voluntarily accept an arrangement that leaves them worse off. Imposition can only occur when interests are different and power asymmetries high. 
Krasner's definition can be used to support the claim that during the East Timor humanitarian crisis, Indonesia's sovereignty was violated. Through coercion, Indonesia had little option but to consent to a UN peacekeeping force. After the financial crisis caused external power interest divergence, the status quo had irreparably changed. Indonesia was weakened by economic and domestic instability. External powers such as Australia and the US used this opportunity to push Jakarta into allowing a vote for independence in East Timor and, subsequently, to accept a UN-mandated peacekeeping force. They did so, despite Habibie clearly stating that this would represent an unacceptable violation of Indonesian sovereignty. As violence escalated in the region, these external powers imposed sanctions on Indonesia, to coerce the state into altering its East Timor policy. By threatening to withhold much needed military and economic aid, Indonesia had little choice but to compromize its sovereignty and accept external power demands. It could even be argued that Indonesia was so weak that it had no option but to consent to peacekeepers entering the region. Despite Indonesian consent, we can argue that coercive measures by external powers caused Indonesia's failure to resist sovereignty violation from actors external to the region.

\section{Theoretical assessment of the East Timor crisis (1999)}

The foregoing analysis has shown that, during the East Timor humanitarian crisis of 1999, decreased interest convergence between Indonesia and the US and Australia caused Indonesia's failure to resist sovereignty violation by actors external to the region. Prior to the Asian Financial Crisis of 1997, external power interests were convergent with Indonesian interests, causing these states to acquiesce to Indonesia's activities in East Timor. Nor did domestic pressures, such as Congressional restraints or the activities of NGOs and other domestic protest movements, significantly impact on these interests. During this period, Indonesia remained the ASEAN vanguard state. Indonesia, believing East Timor to be its 27 th province, clearly had the most compelling interests at stake with regard to the territory. The ASEAN states, often under the watchful eye of Jakarta, continued to maintain support for Indonesia's East Timor policy.

The 1997 Asian financial crisis acted as a catalyst for external power interest change. It was in the interests of Australia and the US to have a strong and stable Indonesia in the region. Indonesia's economic and 
domestic instability now posed a significant threat to the regional environment. The subsequent downfall of Suharto also represented an opportunity for the US and Australia to play a direct role in helping to implement transitional democratic reform in Indonesia. This was a secondary interest of these states that the more benign post-Cold War environment allowed them to pursue. In doing so, East Timorese right to self-determination came to dominate the agenda. It became apparent to the US and Australia that the benefits of action in relation to Indonesia and its East Timor policy far outweighed the costs of inaction. These states ultimately sought to secure their own interests, and to prevent a regional power vacuum.

To elicit a change in Indonesia's East Timor policy, these external powers were able to use two key strategies to their advantage. First, they openly stated that Indonesia should allow the East Timorese a right to self-determination. In doing so, Indonesia automatically lost Western power support, which had lent a large degree of credibility to Indonesia's claim over East Timor. Second, the US and Australia used Indonesia's economic situation to their advantage. Specifically, coercive measures to withhold economic aid were used in order to implement changes in line with external power interests. These strategies had the required effect. Indonesia capitulated to external power pressure, stating it would allow the East Timorese a referendum to determine East Timor independence. This set in motion a chain of events that would ultimately lead to a devastating humanitarian crisis and external intervention by way of a UN-mandated peacekeeping force. Despite external power interest change, Indonesia remained the vanguard state, and maintained support within ASEAN, many of whom feared the ramifications of potential Indonesian Balkanisation at a time of severe economic instability. Indonesia and the ASEAN states also feared Western intervention in the region under the auspices of humanitarianism. This was regarded as a way for external powers to secure their own interests in the region. As an Association, ASEAN continued its support for Indonesia in the face of international condemnation.

Significantly, support within ASEAN for Indonesia's East Timor policy was not enough to prevent Indonesia's eventual sovereignty violation. This raises questions about ASEAN and its ability to maintain regional autonomy under challenge from sufficiently powerful external actors. It also suggests that external powers play a vital role in the dynamics of ASEAN state resistance to sovereignty violation. Analysis of the regional environment in 1999 supports the hypothesis that a decrease in interest convergence between a vanguard state and 
designated external actors caused a failure of ASEAN vanguard state resistance to sovereignty violation, from powers external to the region.

\section{Contrasting theoretical arguments}

The humanitarian crisis that devastated East Timor is noticeably underemphasized in the existing constructivist literature, which emphasizes ASEAN autonomy and 'regional solutions for regional problems, with minimal intervention by outside powers'. ${ }^{253}$ However, in the case presented here, there appears little evidence that ASEAN adhered to this norm. Acharya states that the 'regional solutions to regional problems' norm must not be conflated with self-reliance, 'but rather with the right not to be ignored or sidelined by outside powers ... in the management of Southeast Asian affairs' ${ }^{254}$ ASEAN's challenge is therefore 'not to achieve self-reliance, but to coordinate the seeking and channelling of outside support'. ${ }^{255}$ The East Timor case is a clear example of ASEAN's failure to achieve this goal. External power intervention occurred without ASEAN support, and despite vocal opposition from the ASEAN member states.

All constructivist authors frame the East Timor crisis with respect to the norm of non-interference. Acharya takes the stance that ASEAN's 'reluctance to dilute its non-interference doctrine' prevented the ASEAN states from providing an effective response to the humanitarian crisis. $^{256}$ In this view, ASEAN state reluctance to contribute to INTERFET, despite Indonesia's request 'further attested to the continued salience of non-intervention' ${ }^{257}$ For Acharya, the East Timor crisis is an example of ASEAN's inability to respond to the crisis due to its respect for the Association's norms. That ASEAN state adherence to non-interference actually exacerbated regional instability is underemphasized. Indeed, this is a point made by Alice Ba, who refers briefly to East Timor, stating that the emerging crisis 'destabilized' ASEAN's established norm and practice of not interfering in their neighbour's affairs and added another layer to already difficult intra-ASEAN debates'. ${ }^{258}$ Missing from Acharya's and Ba's discussion of East Timor is an admission that, by adhering to the non-intervention norm, these states effectively invited external intervention into the region. In doing so, they contravened the ASEAN norm of regional autonomy. This suggests a flaw in the conceptualization of ASEAN's norms.

Only Haacke appears to highlight the tension between these two norms. Haacke acknowledges the significance of ASEAN state participation in intervention forces such as INTERFET, admitting that 
some of the shared understanding 'intrinsic to ASEAN's long-standing diplomatic and security culture have been relaxed, particularly the principle of non-interference'. ${ }^{259}$ Haacke also notes that the Australialed international force, 'demonstrated ASEAN's incapacity to address regional problems on its own terms' ${ }^{260}$ However, he argues that 'it seems premature to consider the [INTERFET] participation ... as evidence of the demise of ASEAN's diplomatic and security culture'. ${ }^{261}$ For Haacke, the norms associated with the 'ASEAN Way' are 'still perceived to serve the important and necessary function of ... limiting interference by non-ASEAN states'. ${ }^{262}$ The evidence presented here does not validate Haacke's conclusion.

As a case study, the East Timor humanitarian crisis of 1999 conforms well to realist expectations. According to Michael Leifer, 'regional order in the grand sense has been beyond the capacity of ASEAN'. ${ }^{263}$ One reason for this is that 'the Association was established as the institutional fruit of conflict resolution'. ${ }^{264}$ Since this time, there has been 'an absence of any distinctive ... peace process in respect of any intra-mural dispute'. ${ }^{265}$ In the period following 1997, 'ASEAN's round of troubles had only just begun as a period of regional economic turmoil ensued ... which has been well beyond the competence of the Association to address on any exclusive basis'. ${ }^{266}$ This was compounded by the resignation of Suharto in 1998, which 'left an enlarged and less cohesive ASEAN in a diminished condition'. ${ }^{267}$ The ASEAN of the 1990s was therefore 'a much more diverse and cumbersome entity; while the changes in its scale means that an earlier intimacy in political communication and consultation is no longer possible'. ${ }^{268}$

Taking a similar view, David Jones and Michael Smith argue that in the period after the financial crisis, the Association's purpose 'seemed to consist of concealing fundamental differences of view among its members under the guise of consensus and non-interference'. ${ }^{269}$ This supports their assessment that 'since 1997, the security situation in East Asia reveals ... that the ASEAN states possess no clear strategy to respond to the challenges the organisation currently faces'. ${ }^{270}$ For Jones and Smith, 'ASEAN has floundered in its attempts to manage both the regional economic crisis and its legacy of intercommunal violence and separatist struggles'. ${ }^{271}$ The ASEAN norm of non-interference 'has only intensified the failure'. ${ }^{272}$ This is because 'non-interference negates the expression of a region. It merely denotes recognition of a collocation of independent sovereign states' ${ }^{273}$

Jones and Smith contend that 'only since 1997 has Canberra begun to ask how to stabilize a disintegrating Southeast Asia rather than integrate itself with a rapidly integrating region'. ${ }^{274}$ Similarly, it is only 
after the East Timor crisis in 1999 that 'Canberra and Washington realized how important a proactive Australia and a supportive US are to the maintenance of a regional balance'. ${ }^{275}$ Ultimately, 'the members of a hollow ASEAN need an American and Australian presence far more than the US and Australia need them, as the stabilisation of East Timor - where ASEAN proved utterly ineffectual - demonstrated' ${ }^{276}$ The realist assessment of ASEAN's role in the post-1997 period is persuasive. As evidence provided in this chapter shows, ASEAN was unable to provide a response to the East Timor crisis of 1999, and external powers played a key role in maintaining regional stability. Ultimately, ASEAN unity was unable to prevent Indonesian sovereignty violation from actors external to the region.

For critical theorist Lee Jones, the application of non-interference to East Timor was 'coercively enforced by the Suharto regime and its allies in neighbouring countries' oligarchic classes, as a means of limiting scope of conflict over East Timor'. ${ }^{277}$ This application of non-interference 'emerged out of a coercive struggle involving states, business groups and civil society organizations'. ${ }^{278}$ Jones similarly argues that ASEAN's response to the 1999 crisis was 'principally due to their fear of contagion from the social and economic unrest spreading from Indonesia'. ${ }^{279}$ At this time, 'core ASEAN states, which had been most badly affected by the Asian crisis and the growing unrest in Indonesia ... felt compelled to intervene'. ${ }^{280}$ They therefore 'actively encouraged and participated in a humanitarian intervention in East Timor', ${ }^{281}$ becoming 'increasingly involved in Indonesia's "internal" affairs'. ${ }^{282}$ This culminated in the ASEAN states rapidly 'preparing for a peace-enforcement intervention, committing their forces before [italics in text] Western states did'. ${ }^{283}$

There are two limitations to Jones' argument. First, there is evidence to suggest that Jones has overemphasized the role of ASEAN in the crisis. Evidence presented in this chapter actually contradicts Jones' argument, and shows how the ASEAN states vocally opposed Western intervention in East Timor on the grounds of humanitarianism. Although Australia attempted to gain an early ASEAN contingent to INTERFET, it failed to do so because of ASEAN unwillingness to become involved in the conflict. Arguably, ASEAN had very little role in resolving the humanitarian crisis, hence the need for external power intervention. Jones also fails to address the fact that Indonesia requested an ASEAN contingent to INTERFET. It was only after Indonesia requested an ASEAN presence that the ASEAN states supplied troops to the peacekeeping force. It can therefore be argued that non-interference was not contravened in this case. 
Second, Jones argues that the ASEAN states intervened in the humanitarian crisis because the core ASEAN states 'felt that the fate of their societies and economies was bound up with events in East Timor'. ${ }^{284}$ This argument is less compelling. While it is true that the financial crisis and Indonesian instability had an impact on the ASEAN states, this was by no means uniform. Whereas certain regional states, such as Thailand, were badly affected by the crisis, other core ASEAN states were much less affected. Despite its open economy, the effects of the financial crisis in Singapore were less severe than other states. ${ }^{285}$ Similarly, contraction in the Philippines 'was considerably less severe than those experienced by its neighbours'. ${ }^{286}$ While Jones stresses the fear of separatism as a driving force behind the Philippines' intervention in Indonesia, ${ }^{287}$ this explanation does not sit well with Singapore, which did not have similar domestic considerations. In reality, the Asian Financial Crisis impacted on state interests, acting as a catalyst for change. A subsequent decrease in interest convergence caused a decrease in Indonesian resistance to sovereignty violation from actors external to the region. Although domestic factors can and do play a role, the deciding factor in this case was the role played by external powers. ASEAN support for Indonesia was ultimately of little consequence.

\section{Notes}

1 Jürgen Rüland, "ASEAN and the Asian Crisis: Theoretical Implications and Practical Consequences for Southeast Asian Regionalism", The Pacific Review 13, no. 3 (2000): 421-451.

2 Dupont, "ASEAN's Response to the East Timor Crisis", 163-70.

3 Ciorciari, The Limits of Alignment, 1.

4 Dupont, "ASEAN's Response to the East Timor Crisis", 167.

5 Hidayat Djajamihardja, "A Reporter's View", in Guns and Ballot Boxes, 102.

6 Djajamihardja, “A Reporter’s View”, 104.

7 Kiernan, Genocide and Resistance in Southeast Asia, 132.

8 Kiernan, Genocide and Resistance in Southeast Asia, 132.

9 Damien Kingsbury, East Timor: The Price of Liberty (New York: Palgrave Macmillan, 2009), 60.

10 Damien Kingsbury, East Timor: The Price of Liberty (New York: Palgrave Macmillan, 2009), 60.

11 Kingsbury, East Timor: The Price of Liberty, 61.

12 Cotton, East Timor, Australia and Regional Order, 15.

13 Cotton, East Timor, Australia and Regional Order, 15.

14 Robinson, If You Leave Us Here, We Will Die, 66. 
15 Kingsbury, East Timor, 61.

16 Cotton, East Timor, Australia and Regional Order, 14-15.

17 Kingsbury, East Timor, 62.

18 Nobel Peace Prize Press Release, Oslo, 11 October 1996.

19 Nobel Peace Prize Press Release, 1996.

20 Robinson, If You Leave Us Here, We Will Die, 66.

21 Straits Times, "Ties with Jakarta on the mend, say US senators", 24 April 1992.

22 Straits Times, "Human-rights issue "will not impair US-Indonesia ties", 04 March 1994.

23 Scheiner, "The United States: From Complicity to Ambiguity", 121.

24 Indonesia Diplomatic Handbook. 5th ed. (Washington DC, International Business Publications, 2008), 46.

25 Scheiner, "The United States: From Complicity to Ambiguity", 122.

26 Indonesia Diplomatic Handbook, 46.

27 Indonesia Diplomatic Handbook, 46.

28 Scheiner, "The United States: From Complicity to Ambiguity”, 123.

29 Scheiner, "The United States: From Complicity to Ambiguity", 124.

30 Cotton, East Timor, Australia and Regional Order, 44.

31 Cotton, East Timor, Australia and Regional Order, 44.

32 Burchill, "East Timor, Australia and Indonesia", 174.

33 Paul Jacob, "Australia and Indonesia strengthen bilateral ties", Straits Times, 18 November 1992.

34 Jacob, "Australia and Indonesia strengthen bilateral ties", 1992.

35 Cotton, East Timor, Australia and Regional Order, 45.

36 Aubrey, "Canberra: Jakarta's Trojan Horse in East Timor", 144.

37 David Jenkins, “Australia's helping hand in Indonesia's military muscle”, Sydney Morning Herald, 04 December 1995.

38 Jenkins, "Australia's helping hand in Indonesia's military muscle".

39 Jenkins, "Australia's helping hand in Indonesia's military muscle".

40 Jenkins, "Australia's helping hand in Indonesia's military muscle".

41 Alan Dupont, "The Australia-Indonesia Security Agreement", The Australian Quarterly 68, no. 2 (Winter 1996), 49.

42 Dupont, "The Australia-Indonesia Security Agreement", 49.

43 Burchill, "East Timor, Australia and Indonesia", 170.

44 Burchill, "East Timor, Australia and Indonesia", 170.

45 Burchill, "East Timor, Australia and Indonesia”, 171.

46 Burchill, "East Timor, Australia and Indonesia", 172.

47 Burchill, "East Timor, Australia and Indonesia", 173.

48 Anuraj Manibhandu, "Thailand shuns ceremony", Bangkok Post, 10 December 1996.

49 Cotton, East Timor, Australia and Regional Order, 134. 
50 Xinhua News Agency, "Indonesia has sovereignty over East Timor-Ramos", 11 May 1994.

51 Xinhua News Agency, "Indonesia has sovereignty over East Timor-Ramos".

52 Paul Jacob, "Alatas warns Manila not to allow East Timor meeting”, Straits Times, 17 May 1994.

53 Jacob, "Alatas warns Manila not to allow East Timor meeting".

54 Paul Jacob, “Alatas hails Philippines' decision”, Straits Times, 21 May 1994.

55 Nirmal Ghosh, "Ramos defuses crisis, bans non-Filipinos from meeting", Straits Times, 21 May 1994.

56 Xinhua News Agency, "Ramos defends Manila's action on East Timor conference", 25 May 1994.

57 Bangkok Post, "Govt tightens curbs on NGO activities", 16 July 1994.

58 Bangkok Post, "Govt tightens curbs on NGO activities".

59 Bangkok Post, "Govt threatens to arrest errant rights activists", 20 July 1994.

60 Bangkok Post, "Prasong firm on East Timor Policy", 19 July 1994.

61 Bangkok Post, "Govt threatens to arrest errant rights activists".

62 Sydney Morning Herald, "Jakarta's bungled Timor diplomacy", 10 June 1994.

63 Bangkok Post, "Govt threatens to arrest errant rights activists".

64 Bangkok Post, "Govt threatens to arrest errant rights activists".

65 Nirmal Ghosh, "Laureate barred from Manila during APEC meet", Straits Times, 22 October 1996.

66 Susan Sim, "Jakarta thanks KL for closing Timor meet", Straits Times, 12 November 1996.

67 Jakarta Post, "Indonesia appreciates Malaysian attitude", 12 November 1996.

68 Jakarta Post, "Indonesia appreciates Malaysian attitude".

69 Jakarta Post, "EU warned not to scrutinize East Timor", 1 December 1996.

70 Medyatama Suryodiningrat, "EU dodges East Timor issue in talks", Jakarta Post, 14 February 1997.

71 Suryodiningrat, "EU dodges East Timor issue in talks".

72 Bilveer Singh, "Reports on East Timor not yet neutral", Jakarta Post, 29 November 1994.

73 Thomas Ambrosio, "East Timor Independence: The Changing Nature of International Pressure", in Transforming East Asian Domestic and International Politics, ed. Robert Compton Jr (Aldershot: Ashgate, 2002), 124.

74 Huyn Ngo, "Trade with Indonesia and the Philippines", Northern Territory of Australia Department of Primary Industry and Fisheries, Technical Bulletin No.258, March 1997, 2.

75 Ambrosio, "East Timor Independence", 124. 
76 John T Dori, “Indonesia's Economic and Political Crisis: A Challenge for the US Leadership in Asia", The Heritage Foundation Backgrounder: Executive Summary, 17 August 1998.

77 Dori, “Indonesia's Economic and Political Crisis”, 1998.

78 Dori, "Indonesia's Economic and Political Crisis", 1998.

79 Dori, “Indonesia’s Economic and Political Crisis”, 1998.

80 Kingsbury, East Timor, 65.

81 Dori, "Indonesia's Economic and Political Crisis", 1998.

82 Rüland, "ASEAN and the Asian Crisis", 6.

83 Dori, "Indonesia's Economic and Political Crisis", 1998.

84 Dori, "Indonesia's Economic and Political Crisis", 1998.

85 Dori, "Indonesia's Economic and Political Crisis", 1998.

86 Rüland, "ASEAN and the Asian Crisis", 426.

87 Dick K Nanto, “The 1997-98 Asian Financial Crisis”, CRS Report for Congress No. 97-1021 E, updated 06 February 1998.

88 Michael Shari, "Commentary: For Suharto, A Most Dangerous Game”, Bloomberg Businessweek, 22 March 1998.

89 Shari, "Commentary: For Suharto, A Most Dangerous Game”, 1998.

90 Shari, "Commentary: For Suharto, A Most Dangerous Game", 1998.

91 Ambrosio, "East Timor Independence”, 128.

92 Carmel Budiardjo, "The Legacy of the Suharto Dictatorship", in The East Timor Question, 60.

93 Budiardjo, "The Legacy of the Suharto Dictatorship", 60-1.

94 Dori, "Indonesia's Economic and Political Crisis", 1998.

95 Budiardjo, "The Legacy of the Suharto Dictatorship", 61.

96 Budiardjo, "The Legacy of the Suharto Dictatorship", 62.

97 Kingsbury, East Timor, 66.

98 Geoff Forrester and Ronald James May, The Fall of Soeharto (London: C Hurst \& Co, 1998), 80.

99 Forrester and May, The Fall of Soeharto, 80.

100 Forrester and May, The Fall of Soeharto, 81.

101 Pietsch, "Australian Imperialism and East Timor", 13.

102 Forrester and May, The Fall of Soeharto, 82.

103 Ambrosio, "East Timor Independence", 128.

104 Nanto, "The 1997-98 Asian Financial Crisis".

105 Dori, "Indonesia's Economic and Political Crisis", 1998.

106 Dori, “Indonesia's Economic and Political Crisis", 1998.

107 Dori, “Indonesia's Economic and Political Crisis", 1998.

108 Dori, "Indonesia's Economic and Political Crisis", 1998.

109 Ambrosio, "East Timor Independence”, 124.

110 Pietsch, "Australian Imperialism and East Timor", 14.

111 Ambrosio, "East Timor Independence”, 130. 
112 Cotton, East Timor, Australia and Regional Order, 55.

113 Iain Henry, "Unintended consequences: an examination of Australia's 'historic policy shift' on East Timor”, Australian Journal of International Affairs 68, no. 1 (2014), 56.

114 Senate Resolution 237, "Expressing the Sense of the Senate Regarding the Situation in Indonesia and East Timor", Senate, 22 May 1998, Congressional Record Page S5459, http://etan.org/action/237sres.htm.

115 Senate Resolution 237, "Expressing the Sense of the Senate".

116 Cotton, East Timor, Australia and Regional Order, 46.

117 Cotton, East Timor, Australia and Regional Order, 46.

118 Cotton, East Timor, Australia and Regional Order, 46.

119 Ambrosio, "East Timor Independence", 129.

${ }^{120}$ Hugh White, “The Road to INTERFET: Reflections on Australian Strategic Decisions Concerning East Timor, December 1998-September 1999", Security Challenges 4, no. 1 (Autumn 2008), 71.

121 White, “The Road to INTERFET", 71.

122 White, “The Road to INTERFET", 71.

123 Cotton, East Timor, Australia and Regional Order, 89.

${ }^{124}$ Robert Manne, The Howard Years (Melbourne: Black Inc. Agenda, 2004), 272.

125 Manne, The Howard Years, 272.

126 Henry, "Unintended Consequences", 57.

127 Henry, "Unintended Consequences", 57.

128 Burchill, "East Timor, Australia and Indonesia”, 173.

129 Burchill, "East Timor, Australia and Indonesia”, 173.

${ }^{130}$ Henry, "Unintended Consequences", 53.

131 White, “The Road to INTERFET", 73.

132 Henry, "Unintended Consequences", 54.

133 Burchill, "East Timor, Australia and Indonesia", 174.

134 Burchill, "East Timor, Australia and Indonesia", 175.

135 Siti Rahil Dollah, "Downer warns against Indonesia becoming like Balkans”, Kyodo News, 23 February 1999.

136 Alatas, The Pebble in the Shoe, 148.

137 Alatas, The Pebble in the Shoe, 149.

${ }^{138}$ Lee, From Third World to First, 390.

139 Alatas, The Pebble in the Shoe, 150.

${ }^{140}$ Henry, "Unintended Consequences", 64.

${ }^{141}$ Robinson, If You Leave Us Here, We Will Die, 94.

${ }^{142}$ Henry, "Unintended Consequences", 65.

${ }^{143}$ Clinton Fernandes, "The Road to INTERFET: Bringing the Politics Back In”, Security Challenges 4, no. 3 (Spring 2008), 87.

${ }^{144}$ Fernandes, "The Road to INTERFET", 87. 
145 Aubrey, “Canberra: Jakarta's Trojan Horse in East Timor", 146.

146 Aubrey, "Canberra: Jakarta's Trojan Horse in East Timor", 146.

147 Dupont, "ASEAN's Response to the East Timor Crisis", 163.

148 Xinhua News Agency, "ASEAN wants peaceful settlement of East Timor issue", 12 April 1999.

149 Dario Agnote, "Manila Expresses Concern Over Turmoil in Indonesia”, Kyodo News, 5 May 1999.

${ }^{150}$ Dupont, “ASEAN's Response to the East Timor Crisis", 164.

${ }^{151}$ Kyodo News, "East Timor changes future for ASEAN, Indonesia", 4 September 1999.

${ }^{152}$ Kyodo News, "Japan, US welcome E.Timor result, ASEAN cautious", 5 September 1999.

153 Christopher Dore, "Unfuriated [sic] neighbours", The Australian, 9 September 1999.

154 Dore, "Unfuriated neighbours".

155 Dore, "Unfuriated neighbours".

156 Tim Johnson, "ASEAN wants E.Timor crisis tackled by Indonesia, U.N”, Kyodo News, 09 September 1999.

157 Kingsbury, East Timor, 67.

158 Cotton, East Timor, Australia and Regional Order, 62.

159 Cotton, East Timor, Australia and Regional Order, 63.

160 Cotton, East Timor, Australia and Regional Order, 91.

161 Robinson, If You Leave Us Here, We Will Die, 106.

162 Robinson, If You Leave Us Here, We Will Die, 107.

163 Robinson, If You Leave Us Here, We Will Die, 107.

${ }^{164}$ United Nations General Assembly, "Question of East Timor: Report of the Secretary General”, A/53/951, S/1999/513, 5 May 1999.

${ }^{165}$ UNGA "Question of East Timor: Report of the Secretary General".

166 United Nations Security Council, "Resolution 1246 (1999)", S/ RES/1246, 11 June 1999.

167 UNSC, "Resolution 1246 (1999)".

${ }^{168}$ Iain Henry, "Playing Second Fiddle on the Road to INTERFET: Australia's East Timor Policy Throughout 1999", Security Challenges 9, no. 1 (2013), 96.

${ }^{169}$ Henry, "Playing Second Fiddle on the Road to INTERFET", 97.

170 William Maley, "Australia and the East Timor Crisis: Some Critical Comments”, Australian Journal of International Affairs 54, no. 2 (2000), 156.

${ }^{171}$ Henry, "Playing Second Fiddle on the Road to INTERFET", 99.

${ }^{172}$ Henry, "Playing Second Fiddle on the Road to INTERFET", 99.

173 Robinson, If You Leave Us Here, We Will Die, 115.

${ }^{174}$ Henry, "Playing Second Fiddle on the Road to INTERFET", 100.

175 Robinson, If You Leave Us Here, We Will Die, 119. 
176 Robinson, If You Leave Us Here, We Will Die, 119.

177 Desmond Ball, "Silent Witness: Australian Intelligence and East Timor", The Pacific Review 14, no. 1 (2001), 43.

178 Ball, "Silent Witness", 45.

179 Robinson, If You Leave Us Here, We Will Die, 132.

${ }^{180}$ Robinson, If You Leave Us Here, We Will Die, 148.

${ }^{181}$ Burchill, "East Timor, Australia and Indonesia", 179.

182 Robinson, If You Leave Us Here, We Will Die, 153.

183 Janet Chopra, “The UN's Kingdom of East Timor”, Survival 42, no. 3 (Autumn 2000), 27.

${ }^{184}$ Chopra, "The UN's Kingdom of East Timor", 27.

185 Robinson, If You Leave Us Here, We Will Die, 161, 163.

186 Geoffrey Robinson, "People's War: Militias in East Timor and Indonesia”, South East Asia Research 9, no. 3 (2001), 275.

187 Robinson, "People's War”, 275.

188 Robinson, If You Leave Us Here, We Will Die, 182.

189 Robinson, If You Leave Us Here, We Will Die, 191.

190 Bill Nicol, Timor: A Nation Reborn (Indonesia: Equinox, 2002), 321.

${ }^{191}$ Robinson, If You Leave Us Here, We Will Die, 194.

192 Robinson, If You Leave Us Here, We Will Die, 181, 185, 192.

193 Kingsbury, East Timor, 74.

${ }^{194}$ Robinson, If You Leave Us Here, We Will Die, 189.

195 Kingsbury, East Timor, 74.

196 Kingsbury, East Timor, 74.

197 Kingsbury, East Timor, 194.

198 Pietsch, "Australian Imperialism and East Timor", 21.

199 Cotton, East Timor, Australia and Regional Order, 123.

200 See Clinton Fernandes, "R2P and the East Timor Intervention", in Responsibility to Protect and Sovereignty, ed. Charles Sampford and Ramesh Thakur (Surrey: Ashgate, 2013).

201 Jakarta Post, "Anti-Indonesia Protests Held in Australia over East Timor", 7 September 1999.

202 Burchill, "East Timor, Australia and Indonesia”, 177.

203 Pietsch, "Australian Imperialism and East Timor", 18.

204 Pietsch, "Australian Imperialism and East Timor", 18.

205 White, “The Road to INTERFET”, 85.

206 Robinson, If You Leave Us Here, We Will Die, 191.

207 Robinson, If You Leave Us Here, We Will Die, 191.

208 Robinson, If You Leave Us Here, We Will Die, 196.

${ }^{209}$ Robinson, If You Leave Us Here, We Will Die, 196.

${ }^{210}$ Robinson, If You Leave Us Here, We Will Die, 198. 
${ }^{211}$ United Nations Security Council, "Resolution 1264 (1999)", 15 September 1999, S/RES/1264 (1999).

212 UNSC, "Resolution 1264 (1999)".

${ }^{213}$ UNSC, "Resolution 1264 (1999)".

${ }^{214}$ Kingsbury, East Timor, 74.

215 White, “The Road to INTERFET”, 75.

${ }^{216}$ Cotton, East Timor, Australia and Regional Order, 138.

217 Scoop Independent News, “Australia to Become America's Peacekeeping Deputy”, 23 September 1999.

218 Robinson, If You Leave Us Here, We Will Die, 205.

219 Robinson, If You Leave Us Here, We Will Die, 205.

220 Cotton, East Timor, Australia and Regional Order, 79.

${ }^{221}$ Lee, From Third World to First, 393.

222 Lee, From Third World to First, 393.

223 Sonny Inbaraj, “ASEAN's commitment to East Timor Faces Tough Test”, Asia Times Online, 01 February 2000.

${ }^{224}$ Dupont, "ASEAN's Response to the East Timor Crisis", 164.

225 Dupont, "ASEAN's Response to the East Timor Crisis", 165.

${ }^{226}$ Dupont, "ASEAN's Response to the East Timor Crisis", 165.

227 Dupont, "ASEAN's Response to the East Timor Crisis", 165.

${ }^{228}$ Farhan Haq, "Mahathir calls for reduced Australian presence in Timor", Asia Times Online, 01 October 1999.

229 Cotton, East Timor, Australia and Regional Order, 82.

230 Narine, Explaining ASEAN, 173.

231 Narine, Explaining ASEAN, 173.

232 Lee, From Third World to First, 392.

233 Asia Times Online, "Howard Doctrine provokes Malaysian Rage", 25 September 1999.

234 Cotton, East Timor, Australia and Regional Order, 140.

235 Aubrey, "Canberra: Jakarta's Trojan Horse in East Timor", 147.

236 Donald Emmerson, “Moralpolitik: The Timor Test", National Interest 58 (1999/2000), 67.

${ }^{237}$ Haq, "Mahathir calls for reduced Australian presence in Timor".

${ }^{238}$ Haq, "Mahathir calls for reduced Australian presence in Timor".

${ }^{239}$ Haq, "Mahathir calls for reduced Australian presence in Timor".

${ }^{240}$ Dupont, "ASEAN's Response to the East Timor Crisis", 166.

${ }^{241} \mathrm{Haq}$, "Mahathir calls for reduced Australian presence in Timor".

242 Cotton, East Timor, Australia and Regional Order, 126.

${ }^{243}$ Dupont, "ASEAN's Response to the East Timor Crisis", 167.

${ }^{244}$ Association of Southeast Asian Nations, "Joint Communique of the 33rd ASEAN Ministerial Meeting”, Bangkok, 24-25 July 2000.

245 Cotton, East Timor, Australia and Regional Order, 84. 
246 United Nations Security Council, "Resolution 1272 (1999)”, 25 October 1999, S/RES/1272 (1999).

247 Straits Times, "Human-rights issue "will not impair US-Indonesia ties".

${ }^{248}$ United Nations Department of Peacekeeping Operations and Department of Field Support, "United Nations Peacekeeping Operations: Principles and Guidelines", Peacekeeping Best Practices Section, January 2008, 1-100.

${ }^{249}$ United Nations Charter, “Chapter I: Purposes and Principles”, Article 2(7).

${ }^{250}$ Krasner, Sovereignty: Organized Hypocrisy, 26.

${ }^{251}$ Krasner, Sovereignty: Organized Hypocrisy, 26.

${ }^{252}$ Krasner, Sovereignty: Organized Hypocrisy, 26.

253 Acharya, Constructing a Security Community, 80.

254 Acharya, Constructing a Security Community, 258.

255 Acharya, Constructing a Security Community, 258.

256 Acharya, Constructing a Security Community, 152.

257 Acharya, Whose Ideas Matter? 133.

258 Ba, [Re]Negotiating East and Southeast Asia, 211.

259 Jürgen Haacke, "ASEAN's Diplomatic and Security Culture: a Constructivist Assessment", International Relations in the Asia-Pacific 3, no. 1 (2003), 57.

${ }^{260}$ Haacke, ASEAN's Diplomatic and Security Culture, 200.

${ }^{261}$ Haacke, "ASEAN's Diplomatic and Security Culture", 68.

262 Haacke, "ASEAN's Diplomatic and Security Culture", 57.

${ }^{263}$ Chin and Suryadinata, Michael Leifer: Selected Works, 105. Reprinted in abridged form from Michael Leifer, “ASEAN's Search for Regional Order", Faculty of Arts and Social Sciences Lecture 12, National University of Singapore, 1987.

${ }^{264}$ Chin and Suryadinata, Michael Leifer: Selected Works, 121. Reprinted in abridged form from Michael Leifer, "The ASEAN Peace Process: A Category Mistake", The Pacific Review 12, no. 1 (1999): 25-38.

265 Chin and Suryadinata, Michael Leifer: Selected Works, 127-8.

266 Chin and Suryadinata, Michael Leifer: Selected Works, 132.

267 Chin and Suryadinata, Michael Leifer: Selected Works, 133.

${ }^{268}$ Chin and Suryadinata, Michael Leifer: Selected Works, 134.

${ }^{269}$ Jones and Smith, "ASEAN's Imitation Community", 103.

270 Jones and Smith, ASEAN and East Asian International Relations, 71.

271 Jones and Smith, ASEAN and East Asian International Relations, 71.

272 Jones and Smith, ASEAN and East Asian International Relations, 71.

${ }^{273}$ Jones and Smith, ASEAN and East Asian International Relations, 72.

${ }^{274}$ Jones and Smith, “ASEAN's Imitation Community”, 108.

275 Jones and Smith, “ASEAN's Imitation Community”, 108-9. 
276 Jones and Smith, "ASEAN's Imitation Community", 109.

277 Jones, ASEAN, Sovereignty and Intervention in Southeast Asia, 151.

278 Jones, ASEAN, Sovereignty and Intervention in Southeast Asia, 155.

279 Jones, ASEAN, Sovereignty and Intervention in Southeast Asia, 151-2.

${ }^{280}$ Jones, ASEAN, Sovereignty and Intervention in Southeast Asia, 165.

${ }^{281}$ Jones, ASEAN, Sovereignty and Intervention in Southeast Asia, 157.

282 Jones, ASEAN, Sovereignty and Intervention in Southeast Asia, 159.

283 Jones, ASEAN, Sovereignty and Intervention in Southeast Asia, 159.

${ }^{284}$ Jones, ASEAN, Sovereignty and Intervention in Southeast Asia, 165.

285 Chia Siow Yue, "The Asian Financial Crisis: Singapore's Experience and Response", ASEAN Economic Bulletin 15, no. 3 (1998), 297.

${ }^{286}$ Marcus Noland, "The Philippines in the Asian Financial Crisis: How the Sick Man Avoided Pneumonia”, Asian Survey 40, no. 3 (2000), 401.

287 Jones, ASEAN, Sovereignty and Intervention in Southeast Asia, 171-3. 


\section{The South China Sea Dispute ${ }^{1}$}

The South China Sea dispute (1992 to present) is a long-standing and ongoing maritime sovereignty dispute involving China, Taiwan and the ASEAN states of Brunei, Malaysia, the Philippines, and Vietnam. Tensions over the region's waters have fluctuated since the Cold War period, with instances of conflict linked to a variety of factors, including surging economic growth and corresponding military modernization in China, enhanced competition for maritime resources, China's status as a rising power, increased great power rivalry with the US, and the consolidation of power under China's current President Xi Jinping. ${ }^{2}$ With increased tensions linked to 'renewed Chinese assertiveness', ${ }^{3}$ the South China Sea is 'on the way to becoming the most contested body of water in the world'. ${ }^{4}$

At the forefront of this struggle for autonomy ${ }^{5}$ in the South China Sea sit the ASEAN states of the Philippines and Vietnam. As Southeast Asia's 'frontline states' in the South China Sea dispute, ${ }^{6}$ these states have had their maritime sovereignty violated by China, which has increasingly pushed its own sovereignty claims over the region's rocks, islands and reefs. China took control of the Paracel Islands, also claimed by Vietnam, by force in 1974, establishing a presence on Fiery Cross Reef in 1987. China went on to occupy Mischief Reef in 1995, actions which resulted in military confrontation with the Philippines due to conflicting sovereignty claims over the same territory. Since this period, there have been numerous maritime clashes between Chinese, Vietnamese and Filipino armed forces, of varying levels of intensity. The purpose of this chapter is to assess the ability of the Philippines and Vietnam to resist sovereignty violation from an increasingly assertive China over three separate time periods: 1992-2012, 2012-2016, and 2016 to present.

In the first of these time periods, evidence will show how the US, as the only external power with 'the wherewithal to seriously counter 
China', ${ }^{7}$ was insufficiently concerned with events in the South China Sea to cooperate with either the Philippines or Vietnam in their bid to resist sovereignty violations from China. At the same time, ASEAN failed to reach a consensus on what its own role in the South China Sea dispute should be. Significantly, without a credible security commitment from an external power such as the US, ASEAN was unable to provide an effective response to the dispute. Despite the Philippines and Vietnam having the most compelling interests at stake in the dispute, and therefore increasingly taking on the role of joint vanguard state, both continued to have their sovereignty violated at this time.

A sea change was in evidence from 2012. From this period to 2016, the US increasingly recognized its own vital interests at stake in preventing Chinese expansion and militarization in the South China Sea. Characterized by a foreign policy 'pivot', the Obama Administration recognized the Philippines and Vietnam as the region's frontline states, and increased economic, military, and political cooperation to each accordingly. Despite this, the period can at best be characterized as one of partial interest convergence. Increasing interest convergence between the ASEAN vanguard states and the US did not reach the levels required to prevent the Philippines and Vietnam from having their sovereignty violated by China. This was compounded by relatively weak ASEAN support of vanguard state policy, with the Association still fragmented over how to deal with repeated Chinese transgressions.

From 2016 onwards, shifting US and Philippines' interests heralded a change in each state's China and South China Sea policy, thus exposing the fragility of interest convergence. This has left Vietnam largely isolated, seeking to resist violations to its sovereignty while unsure of US security commitments and the support from ASEAN and its fellow vanguard state. The argument made here is that if Vietnam and the Philippines, in their role as vanguard states, hope to resist sovereignty violations from China, they need to focus on re-engaging the US and developing greater ASEAN cohesion. Failure to do so will result in these states increasingly ceding maritime sovereignty to China.

The chapter will begin by discussing the background to the maritime dispute, including detail of the various regional state interests and the sovereignty claims of each party. It will then provide evidence of ASEAN vanguard state-external power interest divergence between 1992 and 2012. During this period, Chinese land reclamation and militarization of a number of contested islands in the South China Sea sparked conflict with both the Philippines and Vietnam, which gradually emerged as the ASEAN vanguard states. Analysis of the 
period from 2012 to 2016 will show the way in which increasing interest convergence between the US, the Philippines and Vietnam led to increased cooperation regarding the South China Sea dispute. This partial interest convergence was supported by the Obama Administration's 'Asia pivot' policy, and arbitration legal proceedings undertaken by the Philippines. Subsequent analysis of the period 2016 to present will highlight the impact of changing administrations in the Philippines and the US, which contributed to a change in interests towards China and the South China Sea. Evidence will show that this interest divergence has contributed to the ASEAN vanguard states continuing to have their maritime sovereignty violated. The chapter will conclude with a theoretical discussion of the South China Sea dispute since 1992, a summary of the chapter's findings, and consideration of the contrasting theoretical arguments, and their applicability to this case.

\section{Background to the maritime dispute}

China historically considers all territory in the South China Sea to be under its control, despite competing claims with a number of Southeast Asian states. A law was passed to this effect in 1992, in which China asserted its claims to the South China Sea, as well as reserving the right to use force to enforce these claims. ${ }^{8}$ The disputed islands themselves are little more than rocky outcrops in the South China Sea, and are of relatively little land value. This is a view supported by the 1982 United Nations Convention on the Law of the Sea (UNCLOS), which has confirmed that many of the disputed features in the Spratly Islands should be classified as rocks. ${ }^{9}$ Contested sovereignty claims are driven by hydrocarbons and minerals beneath the seabed, in addition to the strategic geographic position of the various islands that straddle vital sea-lanes and trade routes. ${ }^{10}$ China bases its claim to sovereignty on a map produced in 1949 'indicating nine undefined, discontinued and dashed line'. ${ }^{11}$ China claims sovereignty over all features within this 'nine-dash line', despite questions over the legality of China's claim and the exact location of the line's coordinates. ${ }^{12}$ Both China and Vietnam claim sovereignty over the Paracel Islands, which China occupied by force in 1974. The Spratly Islands are also subject to a number of conflicting sovereignty claims, with various islands, rocks and reefs occupied by China, Malaysia, the Philippines, Taiwan and Vietnam. ${ }^{13}$

China has calculated that the South China Sea has the potential to yield 130 billion barrels of oil, which if true would place the region 
second behind Saudi Arabia in terms of oil reserves. ${ }^{14}$ China is in need of this energy, with "Chinese oil reserves account[ing] for only 1.1 percent of the world total, while it consumes over 10 percent of world oil production' ${ }^{15}$ It is also estimated that the South China Sea provides approximately 10 percent of the global catch, which is a significant source of protein for the region's population. ${ }^{16}$ The dispute has also increasingly 'become an issue of dissension between the US and China', with the former seeking to maintain a foothold in the region, while the latter increasingly seeks to exert its influence over the region. ${ }^{17}$ There has been a notable reduction in the size of the US Navy since the 1980s, and a dramatic growth in the size of the Chinese Navy. ${ }^{18}$ For Kaplan, Chinese expansionism 'is a declaration that it never again intends to let foreigners take advantage of it, as they did in the previous two centuries'. ${ }^{19}$

In pursuit of this goal, the period from 2013 has seen accelerated Chinese construction and militarization in the South China Sea. This has included increased land reclamation in the Spratly Islands, the installation of various weapon systems and defence fortifications on all seven of its artificial islands built in the South China Sea, the deployment of surface-to-air missile launchers to Woody Island in the Paracels ${ }^{20}$ and the installation of structures intended to house missile systems on Fiery Cross Reef, Mischief Reef and Subi Reef, all of which have 'military-grade airfields' ${ }^{21}$ China's actions raise a number of important questions regarding future peace and stability in the region, China's regional and international ambitions as a rising power, the continued role of the US as a Pacific power, and the degree to which competition between the two could impact the states of Southeast Asia. For Hayton, the South China Sea is symbolic in that it is 'the first place where Chinese ambition has come face to face with American strategic resolve'. ${ }^{22}$ What remains to be seen is the degree to which these states will seek to pursue these interests, and the extent to which regional ASEAN States will hinder or support this.

\section{ASEAN'S failure to secure interest convergence (1992-2012)}

Despite sovereignty disputes over territory in the South China Sea existing since at least the 1970s, the dispute became more pronounced when Beijing passed the Territorial Waters Law, in February 1992. Adopted at the 24th meeting of the Standing Committee of the 
National People's Congress, the law states China's right to exercize sovereignty over its territorial sea, incorporating offshore islands such as Taiwan, Diaoyu Island, Penghu Islands, Dongsha Islands, Xisha Islands, Nansha (Spratly) Islands and other islands that belong to China. ${ }^{23}$ The legislation was indicative of China's shift towards a new military strategy towards the end of the Cold War. From 1992, conflict over territorial seas and islands was designated of special importance, and the People's Liberation Army Navy (PLAN) were tasked with enhancing offshore defence, and 'over the long term, building a survivable, sea-based nuclear retaliatory force'. ${ }^{24}$

\section{China's creeping assertiveness (1995-1999)}

China's ability to project force was evident in February 1995, when nine vessels were sent to take control of Panganiban atoll, also known as Mischief Reef, territory long claimed by the Philippines. Critically, this was the first time China had moved to occupy maritime territory claimed by an ASEAN country, having previously targeted territory claimed by Vietnam, which did not become an ASEAN member until 1995. While the Philippines lodged a 'strong diplomatic protest' with Beijing, its position was a weak one, and not supported by an ally with the military power to intimidate China. ${ }^{25}$ A US state department spokesperson responded to the incident by confirming that the US 'takes no position on the merits of the competing claims in the South China Sea'. ${ }^{26}$ Michael Leifer accurately summarized the challenge for the Philippines, noting that regional states believed the US had 'lost the will to uphold the regional balance of power', and that ASEAN's own 'inability ... to adopt a common position over the South China Sea' could encourage China's 'creeping assertiveness' ${ }^{27}$

In the aftermath of the Mischief Reef incident, representatives from the Philippines and China met in Manila on 9-10 August 1995 to engage in consultations on the South China Sea. A joint statement was subsequently released, detailing a code of conduct designed to 'build confidence and trust between the two parties'. ${ }^{28}$ Despite the Philippines' hope that this would prevent any further Chinese unilateral action in the region, the 1997 sighting of Chinese warships near Philippine-occupied islands in the Spratlys, in addition to the discovery of further structures on a nearby reef, thwarted these hopes. More Chinese structures were erected in January 1999, this time constructed in concrete, including construction of what appeared to be a helicopter landing-pad. ${ }^{29}$ 
The US response to Chinese gains in the South China Sea was largely one of disinterest. In a 1991 interview held in Malaysia, US Pacific Commander-in-Chief Admiral Charles Larson made a number of comments regarding the Spratly Islands dispute, including the fact that 'there was no interest for the US to intervene', that it was 'a regional issue', and that it was up to ASEAN and countries in the region to 'resolve the issue through political channels'. ${ }^{30}$ With the US preoccupied with securing its interests in the Middle East and North Africa, the Philippines' military chief General Angelo Reyes 'publicly stated that the Philippines could not rely on the US for its defence'. ${ }^{31}$ Nor were the Philippines able to elicit help from its regional neighbours, with ASEAN providing minimal tangible support following the dispute. The Philippines Foreign Affairs Under-Secretary Lauro Baja Jr confirmed that 'on Mischief Reef, we were left alone. The other countries said that while they sympathize and understand our situation, the issue is only a Philippine-China problem'. ${ }^{32}$ Baja explicitly highlighted ASEAN reluctance to become involved in the dispute, stating that 'even some of our ASEAN friends are either mute, timid or cannot go beyond espousal of general principle of peaceful settlement of disputes and polite words of understanding given in the corridors or meeting rooms'. ${ }^{33}$

Despite Chinese actions, it was Malaysia's belief that China was 'fundamentally benign', feelings echoed by Singapore, which did 'not see China's actions as truly threatening'. ${ }^{34}$ Left without the support of traditional allies, compounded by the 1991 termination of US basing rights in Filipino territory, the Ramos Administration focused on developing its own defensive capabilities. ${ }^{35}$ This included modernization of the Armed Forces of the Philippines (AFP). This took the form of a proposal for a $\$ 2$ billion upgrade of the AFP, with a focus on improved military hardware for external defence, and weapons system upgrades for the Navy and Air Force. ${ }^{36}$ The modernization programme particularly focused on the Philippines' Navy (PN), 'designed so that the PN would get most of the program funds to develop its capability for inshore and offshore patrol, surface warfare, detection, and maritime surveillance'. ${ }^{37}$

ASEAN calls for a code of conduct (1992-1999)

ASEAN's first declaration on the potential for conflict in the South China Sea and ways in which this might be ameliorated came in July 1992, in the aftermath of Beijing's passing of the Territorial Waters 
Law. At the 25th ASEAN Foreign Ministers meeting, an 'ASEAN Declaration on the South China Sea' was adopted, in which the Foreign Ministers called for a code of international conduct over the South China Sea. ${ }^{38}$ By July 1996, Ministers became more explicit in their call for a code of conduct, with calls for a plan of action reiterated in the $1998 \mathrm{Ha}$ Noi [sic] plan of action. Concrete steps were made in March 1999, when the Philippines and Vietnam were assigned the task of designing a draft document. ${ }^{39}$ However, trying to obtain ASEAN or Chinese consensus was to prove difficult. Following recommendations made by ASEAN officials in May, the Philippines submitted a 'draft Regional Code of Conduct' for consideration of the 'ASEAN Senior Officials Meeting [SOM] Working Group on ZOPFAN and SEANWFZ [Southeast Asian Nuclear Weapon Free Zone]'. ${ }^{40}$ ASEAN officials finally agreed on a draft code in November 1999, which was then sent to China for consideration.

China agreed to explore the possibility of a joint code of conduct in May 1999. This was in stark contrast to China's traditional preference for settling regional sovereignty disputes bilaterally. China's shifting stance can be attributed to the realization 'that if it continued to stand outside the forum, it risked either being isolated or being a laggard that had no other choice but to accept the previously settled formalities and principles'. ${ }^{41}$ Fears of intervention by external interested parties, most notably the US and Japan, helped drive Chinese decision-making, as did the hope that a code of conduct could serve China's own interests, and avoid the risk of being dictated to by other countries in the region. ${ }^{42} \mathrm{~A}$ protracted period of negotiations followed, with parties disagreeing on the code of conduct's scope, in addition to whether the code should be legally binding or not, something that China steadfastly resisted. To overcome this impasse, Malaysia proposed a non-binding 'Declaration on the Conduct of Parties in the South China Sea'. This approach was subsequently seized upon by China, which insisted upon the adoption of a non-binding code of conduct. ${ }^{43}$ At a stalemate, 'the other ASEAN members had to give in, accepting a political declaration as a stepping-stone towards a formal code of conduct'. ${ }^{44}$

The Foreign Ministers of ASEAN and the People's Republic of China adopted the 'Declaration of the Conduct of Parties in the South China Sea' at the 8th ASEAN Summit in Phnom Penh on 4 November 2002. ${ }^{45}$ The Code of Conduct declared the parties' respect for the freedom of navigation in the South China Sea, and their desire to exercise restraint and resolve territorial disputes without resorting to the threat or use of force. ${ }^{46}$ Despite these provisions, the 
2002 DOC has been subject to misinterpretation and abuse. Most notable is the self-restraint provision, which 'suggests that the parties are to refrain from new occupations'. ${ }^{47}$ However, 'the parties seem to have interpreted the self-restraint clause to imply that they can continue enhancing their presence on features they already occupy'. ${ }^{48}$ Therefore, actions taken to build structures on occupied islands are consistent within the code of conduct declaration. A further major flaw of the 2002 DOC is that it lacks any enforcement mechanisms for non-compliance, in addition to any dispute-settlement mechanisms 'to deal with differences which may arise over the interpretation or application of the provisions in the declaration'. ${ }^{49}$

Despite concerns regarding the applicability of the DOC, the immediate period following its signing saw a general reduction of regional tensions, with China seeking to 'burnish its credentials' with ASEAN 'by launching a "charm offensive". 50 This period saw China enhance multilateral initiatives, including cooperation in the 2005 East Asia Summit (EAS), enhance economic cooperation and Southeast Asian foreign aid, and increase ASEAN-China dialogue. As evidence of this period's reduction in tensions, Chinese exports to and imports from ASEAN countries grew by 450 percent and 625 percent respectively between 1997 and 2006, with a framework agreement for an ASEAN-China Free Trade Area signed in 2002. ${ }^{51}$ In the South China Sea, China, the Philippines and Vietnam signed a Joint Marine Seismic Undertaking (JMSU) in 2004-05, an agreement that sought to undertake joint seismic studies for oil and gas exploration. ${ }^{52}$ Unfortunately, strained relations with Vietnam and increased US activity in the South China Sea meant that this period of calm was not to last.

\section{Tensions in the Sino-Vietnamese relationship}

Vietnam and China's fraught relations were evident during an 18-20 January meeting in 2007. Held between the Chinese and Vietnamese Vice Foreign Ministers, the latter reported being 'extremely disappointed with Chinese preparation for and conduct of the negotiations', which resulted in the Chinese walking out of the session. ${ }^{53}$ A number of multinational energy companies subsequently became embroiled in the two countries' territorial dispute. In a telegram sent from the US Embassy in Hanoi, China was charged with coercing a number of energy companies, including Chevron and British Petroleum (BP), to pull out of offshore gas concessions in 
disputed waters. ${ }^{54}$ According to one Chevron executive, Xiu Dong Jia, China's Political Counselor in Washington summoned Chevron's executive to the Chinese Embassy in Washington DC. There, he warned them that China, had 'indisputable rights over the area, including Nansha Island', and that further activity by them would be a 'grave violation of China's sovereignty'. ${ }^{55}$ Vietnam, unhappy with Chevron's decision to accede to Chinese demands, 'urged the company to proceed and promised the Vietnamese Navy for protection'. ${ }^{56}$

Increased tensions between China and Vietnam over disputed territory in the South China Sea fanned the flames of antiChina nationalism in Vietnam. Over two weekends in December 2007, students in Ho Chi Minh City and Hanoi met in front of China's consulate to demonstrate against China's decision to set up administrative control over the Paracel and Spratly Islands. ${ }^{57}$ In the past, the Vietnamese government had been quick to quash such protests in order to maintain good relations with China. In this case, however, 'political elites in Vietnam, especially nationalist pragmatists, increasingly saw the benefits of popular patriotism to show tenacity against China's creeping expansions and attract international attention'. ${ }^{58}$

\section{The Obama Administration's China policy (2008-2012)}

A change in US policy towards China was evident following the election of President Barack Obama in 2008. Although this did not immediately translate into any explicit move towards interest convergence with interested South China Sea parties, it did highlight US growing interests in the region, and the beginning of a policy designed to pushback against China's expansionism. From 2008 onwards, the US recognized the important interests it had at stake in maintaining a strong presence in the Pacific, with 'renewed US interest in the territorial disputes ... driven by its own goals of re-engagement and sustaining its primacy in the long term, ${ }^{59}$

Tensions between the two powers escalated in 2009, when it was reported that the US ocean surveillance ship Impeccable was harassed by Chinese naval ships in March, with China claiming the US' vessel was in China's exclusive economic zone. The US responded to the incident by stating that they would "continue to operate in those international waters and we expect the Chinese to observe international laws around them' ${ }^{60}$ Events came to a head in early 2010, after it was reported that Chinese officials had referred to the South China Sea as a "core 
interest' in a private meeting with senior US officials in Beijing in March 2010. ${ }^{61}$ If true, the maritime sovereignty dispute would have been elevated to the same importance as Taiwan and Tibet, and would imply that 'Beijing would be willing to use force or the threat of force to defend its sovereignty'. ${ }^{6}$ The report was followed by confusion as to whether officials did in fact delegate South China Sea 'a core interest', with Chinese leaders neither explicitly endorsing nor denying the comment. ${ }^{63}$

The statement was lent credence by Hillary Clinton, who stated that Dai Bingguo, a Chinese senior foreign policy official, made the statement to her in a meeting in May 2010. According to Clinton, 'I immediately responded and said, "We don't agree with that"" ${ }^{64}$ The US added fuel to the fire in July 2010 comments made by Secretary of State Clinton at a meeting of the ASEAN Regional Forum in Vietnam. Apparently 'encouraged by some ASEAN members who had grown uneasy over Chinese intentions in the South China Sea', Clinton gave perhaps the strongest statement to date on the US position on the South China Sea. ${ }^{65}$ Stating that the region 'was pivotal to US national interests', the comments represented a 'radical policy shift' for the US, due to its 'direct regional involvement' in the dispute. ${ }^{66}$ The comments elicited an immediate response from China's Foreign Minister Yang Jiechi, whose accused 'the US of orchestrating an anti-China plot and threatened economic punishment for Southeast Asian nations that sought to stand up to Beijing' ${ }^{67} \mathrm{He}$ is reported to have stated that 'China is a big country and other countries are small countries, and that is just a fact' ${ }^{68}$

\section{$A$ downturn in regional relations: a hamstrung ASEAN}

China's volatile response was not lost on the ASEAN member states present. Singapore's Foreign Minister George Yeo stated that 'there was quite an interesting and sharp exchange between the Americans and Chinese' ${ }^{69}$ The exchange caused some concern within ASEAN over a heavy-handed US involvement in the dispute, with fears of an exacerbation of tensions. As one ASEAN state official confirmed, 'China is a geographic fact that ASEAN has to live with, whereas the US is both far away and fickle'. ${ }^{70}$ The tense exchange also elicited a strong domestic response in China. The People's Daily website posted an online survey asking its readers whether the South China Sea should indeed be designated a 'core interest' ${ }^{71}$ By January 2011, 97 percent of approximately 4,300 respondents had responded in the affirmative. ${ }^{72}$ 
The period from 2008 to 2012 saw a downturn in stability in the South China Sea. This began with a lapse in the Joint Marine Seismic Undertaking between China, the Philippines and Vietnam, as tensions in the region's waters escalated. ${ }^{73}$ Relations between the Philippines and China deteriorated in April 2012, when a Filipino warship became engaged in a standoff with Chinese surveillance ships in the disputed Scarborough Shoal. The Philippines' naval ship remained on the spot for two days before withdrawing, in the hope that this would diffuse tensions. However, China failed to reciprocate, and instead deployed a well-equipped and heavily armed patrol vessel. ${ }^{74}$ Despite filing a diplomatic protest with the Chinese Embassy, the standoff did not ease until two months later, when vessels withdrew due to the arrival of typhoon season, in what was described as a 'carefully choreographed withdrawal'. ${ }^{75}$ The Chinese position was that its maritime vessels were 'in the area fulfilling the duties of safeguarding Chinese maritime rights and interests', and that Scarborough Shoal was 'an integral part of the Chinese territory'. ${ }^{76}$

The 2012 maritime incident triggered an anti-Chinese backlash in the Philippines, where Filipinos staged 'anti-Chinese bullying' demonstrations. ${ }^{77}$ Similar, small-scale, rallies broke out in China, which also sought to punish the Philippines by imposing travel restrictions and non-tariff barriers against its agricultural produce. ${ }^{78}$ For De Castro, the incident reflected China's 'fervent nationalism, growing naval prowess and unilateral moves ... directed against a militarily weak Philippines'. ${ }^{79}$ Nor did the dispute occur out of the blue. In reality, China had been increasing its naval activities in the region's waters since as early as 2010. Filipino fisherman reported a number of incidents of Chinese harassment, in addition to evidence of Chinese construction, in 2011. In one instance, members of the Armed Forces of the Philippines observed Chinese naval ships unloading building materials and erecting posts in the Army Douglas Bank. ${ }^{80}$ The Philippines protested to the Chinese Embassy in Manila, to which China responded that the Philippines must stop 'harming China's sovereignty and maritime rights and interests' ${ }^{\prime}{ }^{81}$

What the 2012 incident at Scarborough Shoal did do, was make 'it obvious to the Filipinos - if it wasn't obvious by then - that they needed a substantial military alliance with the US', ${ }^{82}$ In addition to securing external security commitments from the US, both the Philippines and Vietnam also sought cooperation from ASEAN. However, ASEAN remained hamstrung over how best to respond to China. This was evident at the 45th ASEAN Ministerial Meeting in July 2012, held in the aftermath of the Scarborough shoal standoff. 
The Philippines and Vietnam requested that the Joint Communiqué include references to their maritime disputes with China. However, Cambodia's foreign minister Hor Nam Hong, as ASEAN chair, blocked any mention of the dispute, claiming that these were bilateral issues and should therefore not be included. ${ }^{83}$ Unable to reach an agreement, the Association failed to release a Joint Communiqué for the first time in its 45-year history. This was evidence of China's ability to exploit its close relationship with Cambodia to keep the South China Sea from featuring prominently at ASEAN meetings. ${ }^{84}$

Summary: 1992-2012

Notwithstanding a brief reduction in tensions following the signing of the 2002 DOC, during which time China's unprecedented economic growth allowed it to consolidate power regionally, the period under analysis witnessed increased friction between China and the ASEAN frontline states and, from 2008 onwards, the US. Without a strong regional balance of power, China's creeping expansionism, evidenced by incidents in Mischief Reef and Scarborough Shoal, was largely able to go unchecked. Notable during this period is the lack of interest convergence between the US, Philippines and Vietnam. Evidence presented here suggests that this, coupled with ASEAN's inability to elicit a common response to the crisis, caused the latter states to have their sovereignty in the South China Sea increasingly violated.

\section{ASEAN-US partial interest convergence (2012- 2016)}

From 2012, the US began to take on a greater balancing role visà-vis China in Southeast Asia. As this analysis will show, this was actively encouraged by the Philippines and Vietnam, which sought US security commitments in an effort to prevent further sovereignty violation by an expansionist China. According to Professor Carlyle Thayer, Vietnam saw 'the US presence as a hedge against China's rising military power'. ${ }^{85}$ The Vietnamese viewed themselves as having a role in facilitating this, with a desire to allow a US military presence at Cam Ranh Bay to counter the growing Chinese threat. ${ }^{86}$ While the Vietnamese would have 'like[d] ASEAN to be stronger, in order to be a counterweight to China, they are realistic' ${ }^{87}$ Similarly, following China's actions in Mischief Reef in 1995, the Philippines, confronted 
by China's 'power-politics approach', implemented 'a delicate balancing act'. ${ }^{88}$ This began by seeking enhanced military ties with the US, hoping that the 'presence of the US would deter any Chinese tendency toward regional hegemony'. ${ }^{89}$

\section{The US 'pivot' (2011)}

By late 2011, there was a pronounced shift in US policy towards the Asia-Pacific. In an address to the Australian Parliament on 17 November 2011, President Barack Obama formally outlined his Asia Pacific foreign policy strategy. This reflected a 'broader shift' away from a focus on the Middle East, to what President Obama referred to as 'the vast potential of the Asia Pacific region' ${ }^{90}$ President Obama highlighted five core underlying principles, which would shape the US' strategic shift towards Asia. These were an emphasis on the US' commitment to security in the region, re-engagement with regional organizations, continued efforts to build a cooperative relationship with China, the advancements of US-Asia shared prosperity through free trade and the Trans-Pacific Partnership (TPP), and a support for fundamental rights of every human being. ${ }^{91}$ This 'strategic rebalance' was given further shape by defence secretary Leon Panetta in June 2012 during the Shangri-La Dialogue in Singapore. There, Panetta referenced deepening cooperation with a number of Southeast Asian states. This included multilateral military exercises with Thailand, further military engagement with the Philippines, including work to improve the Philippines maritime presence, the implementation of forward deployment of the Littoral Combat Ships to Singapore, and the advancement of bilateral defence cooperation with Vietnam.

The US Asia-Pacific rebalance was met with some apprehension in Asia, despite the benefits that a more engaged US could bring to the region. Although traditional allies, such as Japan, welcomed the move, some states in Southeast Asia feared an increase in security competition with China that could destabilize the region. Indonesia's foreign minister warned of the dangers of a 'vicious cycle of tensions and mistrust', a feeling echoed by Malaysia and Singapore, with the latter's foreign minister stressing that ASEAN wanted to avoid getting 'caught between the competing interests' of major powers. ${ }^{92}$ These feelings were undoubtedly compounded by regional state fears of American decline, with concerns that the pivot could prove to be an 'empty promise'. ${ }^{93}$ The pivot was greeted more warmly by those states in conflict with China in the South China Sea. These states 
immediately benefited from the US' new posture. In 2012, the US tripled its military funding to the Philippines from $\$ 15$ million to $\$ 30$ million, ${ }^{94}$ and began a $\$ 41$ million cleanup of Agent Orange in Vietnam, the first such cleanup operation conducted by the US. ${ }^{95}$

\section{The Philippines takes a firm stance}

Following the Obama Administration's articulation of its new Asia pivot strategy, and responding to the 2012 Scarborough Shoal standoff, 'hardliners' in Manila began to push the Benigno Aquino III Administration to take a more assertive stance towards China, particularly with regard to Chinese expansion into Philippines' maritime territory ${ }^{96}$ It did so through the use of three counter-measures: international diplomatic pressure, the initiation of legal proceedings against China, and support of the Obama Administration's 'Pivot to Asia' foreign policy strategy, whereby President Aquino, 'sought to fortify defense relations with America in order to deter further Chinese assertiveness' ${ }^{97}$ The Aquino government also sought to improve its own military capabilities, including a 'border protection programme' centred around enhanced air force, naval and coastguard surveillance, patrol and deterrence capabilities. ${ }^{98}$ The Philippines' stance on the South China Sea dispute was formally expressed in January 2013, when the government confirmed that it would bring China before the Permanent Court of Arbitration (PCA) under Article 287 and V II of the 1982 UNCLOS to "clearly establish the sovereign rights and jurisdiction of the Philippines over its maritime entitlements in the West Philippine Sea. ${ }^{9}{ }^{9}$

The Philippines requested that the arbitration tribunal address four key points. First, that the 'Tribunal resolve a dispute between the Parties concerning the source of maritime rights and entitlements in the South China Sea', thereby directly seeking to challenge China's 'nine-dash line' claim. ${ }^{100}$ Second, that the Tribunal address entitlements to maritime zones and certain maritime features claimed by both parties, including submerged banks and low-tide elevations. Third, that the Tribunal address the 'lawfulness of China's actions in the South China Sea', with a specific focus on Chinese interference in Philippines' fishing, navigation and exploration rights, in addition to its failure to protect the marine environment. ${ }^{101}$ Finally, that the Tribunal find 'that China has aggravated and extended the disputes between the Parties', through its maritime construction and land-reclamation efforts. ${ }^{102}$ In light of the fact that the UNCLOS does not address land-based sovereignty claims, the Tribunal confirmed that it would 
not 'make any ruling as to which State enjoys sovereignty over any land territory in the South China Sea', including the Spratly Islands and Scarborough Shoal. ${ }^{103}$ Nor does it propose to delimit maritime boundaries between the two parties, something that China excluded from the dispute settlement process in 2006.

\section{State responses to the PCA}

China reacted angrily to the Philippines arbitration case. On 20 February 2013, China's Foreign Ministry Spokesperson Hong Lei stated that China 'would continue to 'unswervingly safeguard national sovereignty and interests'. ${ }^{104}$ On 7 December 2014, China's Ministry of Foreign Affairs released a 'Position Paper', not formally submitted to the Tribunal, which elaborated on the reasons why China believed the Arbitration Court lacked jurisdiction with respect to the case. These positions were that the subject matter of territorial sovereignty over maritime features was beyond the scope of the Convention, that the Philippines had breached its obligation under international law to settle relevant disputes through bilateral negotiations, and that, even assuming the subject matter were concerned with the application of the Convention, it would constitute maritime delimitation between the two countries, which China had excluded from compulsory arbitration in 2006. ${ }^{105}$ China made it clear that the release of the position paper 'shall not be regarded as China's acceptance of or its participation in the arbitration'. ${ }^{106}$

In support of the Philippines case, and evidence of growing interest convergence between the two ASEAN states, Vietnam independently joined the arbitration case in December 2014, albeit not as a coplaintiff. Vietnam's Ministry of Foreign Affairs Le Hai Binh confirmed that 'to protect its legal rights and interests in the East Sea which may be affected in the South China Sea arbitration case, Viet Nam [sic] has ... requested the Tribunal to pay attention to the legal rights and interests of Viet Nam'. ${ }^{107}$ Detailing these interests, he confirmed that Vietnam 'has full historical evidence and legal foundation to reaffirm its sovereignty over the Hoang Sa and Truong Sa archipelagos', and that Vietnam fully rejected 'China's claiming of 'historic rights' to the waters, sea-bed and subsoil within the "dotted line" unilaterally stated by China'. ${ }^{108}$ China's Foreign Ministry Spokesperson spoke out against Vietnam's involvement in the arbitration case, stating that the 'Chinese side urges the Vietnamese side to earnestly respect China's territorial sovereignty and maritime rights and interests'. ${ }^{109}$ 
The US, whilst not becoming directly involved in the arbitration, made its support for the Philippines and Vietnam clear. President Obama publicly stated his support for the Philippines' decision to start arbitration proceedings in April 2014, remarking at a Joint Press Conference in Manila that he and President Aquino had 'reaffirmed the importance of resolving territorial disputes in the region peacefully ... in that spirit, I told him that the US supports his decision to pursue international arbitration concerning territorial disputes in the South China Sea'. ${ }^{110}$ In April 2015, President Obama stated that 'where we [the US] get concerned with China is where it is not necessarily abiding by international norms and rules and is using its sheer size and muscle to force countries into subordinate positions' ${ }^{111}$ He concluded that, 'just because the Philippines or Vietnam are not as large as China doesn't mean that they can just be elbowed aside'. ${ }^{112}$

ASEAN state responses to the Philippines' decision to begin arbitration proceedings against China were generally unfavourable. This is evidence that, despite increasing interest convergence between the Philippines, Vietnam and the US, a cohesive ASEAN policy remained elusive. As Tang Siew Mun highlights, Manila's decision 'was seen in 2013 by ASEAN as a wrong tactical step that undermined its efforts towards engaging China multilaterally in striving for a binding Code of Conduct'. ${ }^{113}$ In addition to this, there was a 'sense of disappointment within ASEAN circles that Manila neglected to undertake prior consultation with the grouping'. ${ }^{114}$ In comments to media following the Philippines' initiation of arbitration against China, Singapore's Minister for Foreign Affairs stated that 'what the Philippines has done is a national decision', and that 'Singapore first knew about this action from media reports'. ${ }^{115}$ The Minister stated Singapore's position, which was that it is 'not a claimant state and that by their very nature, the specific territorial disputes in the South China Sea could only be settled by the parties directly concerned'. ${ }^{116}$

\section{Vietnam and US adopt an aggressive China policy}

The need for a coordinated response to the South China Sea dispute took on a degree of urgency in May 2014, when tensions between China and Vietnam threatened to descend into open armed conflict. A clash between Vietnamese and Chinese shipping vessels broke out, following China's deployment of an oilrig in disputed waters 130 nautical miles off the Vietnamese coast. China, accusing Vietnam of ramming its ships, reciprocated and fired water cannons on its 
crew. ${ }^{117}$ The clash damaged a number of vessels on both sides, with at least six Vietnamese casualties reported. ${ }^{118}$ It was followed by antiChinese riots held in Vietnam, which resulted in at least four deaths and over 100 people injured. ${ }^{119}$ Amid the violence, China was forced to evacuate several thousand Chinese workers from the country. ${ }^{120}$ Further clashes in the waters around the oilrig continued into late May, when a Chinese vessel rammed and sank a Vietnamese boat. In the aftermath, China's vice foreign minister stated that 'being the lifeline for China, the South China Sea is far more important to China than to other countries'. ${ }^{121}$

Statements made by Ashton Carter during an annual security policy forum held in Singapore in May 2015 suggested the adoption of a more aggressive US posture. Carter characterized the Chinese islands as 'massive outposts' and warned against 'militarization' of the China Sea: the 'bluntest warnings yet to Beijing'. ${ }^{122}$ The US conducted Freedom of Navigation (FON) operations in the South China Sea in October 2015, January 2016 and May 2016, something which China expressed 'strong dissatisfaction and opposition' to. ${ }^{123}$ In the wake of the October 2015 USS Lassen operation, the Philippines stated that it had "no issue as to this US naval ship traversing under international law'. ${ }^{124}$ These sentiments were echoed by a Vietnamese spokesperson, Malaysia's Defense Minister Hishammuddin Hussein, and Singapore's Minister of Foreign Affairs. ${ }^{125}$ At the Shangri-La conference in May 2015, US Secretary of Defence Ashton Carter confirmed that it 'would not be deterred' from exercising its right to freedom of navigation in the South China Sea. ${ }^{126}$ Undeterred, China continued its militarization policy in the South China Sea. Satellite photos emerged in December 2016 of new anti-aircraft guns and missile defence systems on a number of contested islands. This is in addition to numerous Chinese naval ships operating in the region's waters. Reports in September 2016 also hinted at continued dredging and land reclamation around Scarborough Shoal, a move denied by Chinese officials. ${ }^{127}$

\section{Increased vanguard-US interest convergence}

By late 2015, there was increasing evidence of interest convergence between the US and the Philippines. An Enhanced Defense Cooperation Agreement (EDCA) was signed between the two countries in April 2014 to 'allow for the enhanced rotational presence of US forces at agreed locations in the Philippines'. ${ }^{128}$ The Philippines 
Supreme Court upheld the agreement in January 2016, at which point it went into the implementation phase, with the Philippines offering the US eight bases to build equipment facilities, some based on the island of Luzon. ${ }^{129}$ The EDCA is significant in that it "conveyed a strong diplomatic signal to Beijing that it would have to take account of American military presence in the Philippines if it was to use force against Manila'. ${ }^{130}$ The implementation of the EDCA came one year after more than 100 Navy ships docked in Subic Bay in a regional show of force and US-Philippines cooperation. ${ }^{131}$

President Obama and President Aquino held a bilateral meeting on 18 November 2015 in Sofitel, to discuss enhanced defence alliance between the two states. In a speech made after the meeting, Obama iterated US desire to 'reaffirm ... unwavering commitment to the security and defence of the Philippines', and confirmed commitment 'to ensuring maritime security in the region'. ${ }^{132}$ In a bid to enhance the Philippines defence, Obama outlined US plans to increase 'maritime security assistance to the Philippines to record levels, including two new vessels'. ${ }^{133}$ When asked if he was comfortable with an enhanced US presence in the South China Sea, President Aquino responded: 'I think everybody would welcome a balance of power anywhere in the world'. ${ }^{134}$ The Philippines announced in 2015 that it would spend a record $\$ 552$ billion on defence spending to 'purchase frigates, surveillance planes, and radar equipment to improve surveillance and detection', in disputed areas of the South China Sea, ${ }^{135}$ in addition to stepped-up joint patrols with the US. ${ }^{136}$

Similar growing interest convergence was evident between the US and Vietnam. President Truong Tan Seng travelled to the White House in July 2013 for a bilateral meeting with President Obama, where the two discussed enhanced political, economic and military-to-military cooperation. On the South China Sea, Truong stated his appreciation for 'US support for our stance in this matter, as well as the stance of ASEAN'. ${ }^{137}$ Following the visit, the two countries implemented a Comprehensive Partnership, signed in July 2013. This framework for bilateral relations included a commitment of $\$ 32.5$ million in maritime capacity building assistance for Southeast Asia, with $\$ 18$ million to enhance Vietnamese coastal patrols. ${ }^{138}$ The Vietnamese president 'welcomed the US' enhanced cooperation in the Asia-Pacific, which contributes to the peace, stability, and prosperity of the region'. ${ }^{139}$

In 2015 the two countries implemented a Joint Vision Statement, which stated both sides 'commit[ment] to maximizing shared interests', in addition to recognition of the need to uphold international law and maritime security in the South China Sea. ${ }^{140}$ President Obama 
reciprocated Vietnam's visit in May 2016, with a trip to Hanoi to meet with Vietnam's President Quang. It was announced during this trip that the US would 'completely lift the ban on lethal weapon sales to Vietnam ... clear proof that both countries have completely normalized relations'. ${ }^{141}$ Obama confirmed that 'this change will ensure that Vietnam has access to the equipment it needs to defend itself and removes a lingering vestige of the Cold War'. ${ }^{142}$ This was a significant step, demonstrating a deeper phase of defence cooperation between the two states that would help Vietnam face the perceived Chinese threat. The President of Vietnam's Centre for Strategic Studies confirmed the move to be 'of great importance to Vietnam', continuing that 'China should think twice over anything they can do to Vietnam or the South China Sea ... they should get the message'. ${ }^{143}$

Evidence has also been apparent of increasing interest convergence between the Philippines and Vietnam, as ASEAN's joint vanguard states. On September 2015, Vietnamese Ambassador to the Philippines Truong Trieu Duong stated that Vietnam and the US would 'deepen ... cooperation in order to solve all the issues concerning the South China Sea in a most peaceful way in accordance with international law'. ${ }^{144}$ During an Asia-Pacific Economic Cooperation summit, held on 17 November in Manila, the two countries elevated their relationship through the signing of a strategic partnership. As President Truong stated, 'President [Aquino] and I shared our concerns over the recent developments in the East Sea or the South China Sea, affecting trust, peace, security and stability in the region. We also reaffirmed the importance of ensuring the stability, maritime security, safety and freedom of navigation and of flight in the South China Sea' ${ }^{145}$ Aquino echoed Truong sentiments, stating that 'in terms of defence relations, we [the Philippines] welcome the active engagement and cooperation between our respective defense and military establishments' ${ }^{146}$

While ASEAN remained fragmented over how to respond to sovereignty violations in the South China Sea, thus falling short of the cohesion and mobilization needed to support vanguard state interests, this did not stop the US from attempting to garner a deeper level of cooperation with the Association. In February 2016, President Obama invited all ASEAN leaders to an ASEAN Summit at Sunnylands resort in California, the first Summit to be held in the US. In a joint statement released following the summit, the leaders called for a 'shared commitment to peaceful resolution of disputes', in addition to 'ensuring maritime security and safety ... as well as non-militarization and self-restraint in the conduct of activities'. ${ }^{147}$ President Obama confirmed that 'we discussed the need for tangible 
steps in the South China Sea to lower tensions including a halt to further reclamation, new construction and militarization of disputed areas ... when ASEAN speaks with a clear and unified voice, it can help advance security, opportunity and human dignity' ${ }^{148}$

Summary: 2012-2016

Momentum towards enhanced interest convergence grew from 2012 onwards, with increased instances of cooperation and military coordination between the Philippines, the US, and Vietnam. Evidence of enhanced cooperation between the Philippines and Vietnam also confirms the two states' burgeoning role as joint ASEAN vanguard states. Missing from the equation was a robust ASEAN response, with the Philippines and Vietnam unable to mobilize the Association in support of their own interests. Instead, China was able to use its influence among certain ASEAN states to frustrate efforts to coordinate a joint policy. The period can therefore be best understood as one of partial interest convergence. ASEAN states might have more openly supported the Philippines and Vietnamese position, if this were backed by a powerful US regional presence. However, US re-engagement was tempered by Obama Administration concerns 'of triggering an allout confrontation with China'. ${ }^{149}$ ASEAN concerns are exemplified by March 2016 comments made by Singapore's Prime Minister Lee Hsien Loong, who stated that there 'must be no doubt in anybody's mind that America is a Pacific power, that you have an interest in the region'. ${ }^{150}$ Lee concluded that the US 'do have serious interests at stake. And you have to speak with one coherent voice'. ${ }^{151}$

\section{The arrival of Trump and Duterte - interest divergence (2016 to present)}

The advent of a newly elected leader in the Philippines in May 2016 transpired to derail this burgeoning interest convergence. In the aftermath of his electoral victory, President Rodrigo Duterte announced that he would be 'chartering [sic] a [new] course [for the Philippines] on its own and will not be dependent on the US'. ${ }^{152}$ Duterte made it clear that he would 'open alliances with China' and Russia, and would 'open up the Philippines for them to do business, alliances of trade and commerce'. ${ }^{153}$ This shift towards improved relations with China in exchange for economic support was clearly at 
the expense of the Philippines' territorial claims in the South China Sea. As rumours of human rights abuses committed during Duterte's war on drugs began to circulate to the international community, ${ }^{154}$ the relationship between the Philippine President and his American counterpart began to deteriorate.

These strained relations served as backdrop to the Permanent Court of Arbitration ruling, which was announced on 12 July 2016. A press release issued on that day provided a brief overview of the Tribunal's decision. This confirmed that China's claim to historic rights to resources in the South China Sea, was 'incompatible with the exclusive economic zones provided for in the convention', and that 'there was no evidence that China had historically exercised exclusive control over the waters [italics in text] or their resources'. ${ }^{155}$ As such, 'there was no legal basis' for China to claim historic rights within the nine-dash line. ${ }^{156}$ The Tribunal also found that none of the features claimed by China are capable of generating an entitlement to extended maritime zones, and that certain sea areas form part of the exclusive economic zone of the Philippines, 'because those areas are not overlapped by any possible entitlement of China'. ${ }^{157}$ The Tribunal could therefore confirm that 'China had violated the Philippines' sovereign rights in its exclusive economic zone', by interfering with Filipino fishing and exploration, and through its construction of artificial islands. ${ }^{158}$

\section{An ASEAN divided}

President Duterte's response to this landmark ruling in support of the Philippines position was noticeably muted. This was significant evidence of his shifting stance towards China. Duterte stated in December 2016 that he would 'set aside the arbitral ruling. I will not impose anything on China'. ${ }^{159}$ This was echoed by the Philippines' Foreign Secretary Perfecto Yasay Jr, who stated that he wanted 'to make sure that there will be no further actions that will heighten the tensions between the two countries, particularly in the Scarborough Shoal'. ${ }^{160}$ Yasay concluded that 'we cannot stop China at this point in time ... we will continue to pursue peaceful means' to the dispute. ${ }^{161}$ This approach was welcomed by China, which had dismissed the PCA ruling as a 'null and void decision', and 'nothing more than a piece of paper'. ${ }^{162}$ For Cruz De Castro, 'the Philippines government's cautious reaction to the PCA awards was due to the Duterte administration's fear that flaunting its legal victory against China might force the latter to react adversely against Filipino fishermen' in the South China Sea. ${ }^{163}$ 
In the wake of the PCA ruling, Duterte stepped up his denigration of the US, while simultaneously dropping attempts to push the South China Sea as an agenda item at ASEAN meetings. In advance of an August 2017 ASEAN Summit to be held in Laos, Duterte confirmed that be would not push for a multilateral response to the dispute, stating 'I will only bring the issue when we are face to face ... because if you quarrel with them now and you claim sovereignty, make noise here and there, they might not just even want to talk'. ${ }^{164}$ This clear nod towards China's preference to manage the dispute bilaterally rather than multilaterally has damaged ASEAN confidence in the Philippines, with Duterte's efforts to woo China having 'eroded the Philippines' influence in the ASEAN on the South China Sea issue'. ${ }^{165}$ The Laos Summit concluded without the adoption of a joint statement on the South China Sea dispute. ${ }^{166}$ An official statement issued at the close of the Summit made brief reference to the maritime tensions, but omitted referring to China by name, and failed to explicitly mention the July, South China Sea Arbitration ruling. ${ }^{167}$

Disagreements between the ten ASEAN states were also evident at the previous Foreign Ministers Meeting, held in the immediate wake of the Permanent Court of Arbitration ruling. Both the Philippines and Vietnam requested that the Joint Communiqué mention the PCA ruling. ${ }^{168}$ However, any mention of the ruling was blocked by Cambodia, which claimed the dispute should be dealt with on a bilateral basis. ${ }^{169}$ An extended deadlock ensued, during which it was feared ministers would be unable to agree a joint statement. A watered-down statement was eventually released, devoid of any mention of China's maritime activities, or the PCA ruling. ${ }^{170}$ This was widely viewed as a diplomatic coup for China. In the aftermath of the July meeting, Cambodia's Council of Ministers spokesman Phay Siphan asked, 'why are those individuals, which tend to support the US, pushing Cambodia to support this or that? ... They have a trend of supporting the US, which is against China, but they accuse Cambodia because Cambodia is a close friend to China' ${ }^{171}$ It is perhaps notable that in the immediate aftermath of the PCA ruling, and in advance of the ASEAN foreign ministers summit, Cambodia's Prime Minister Hun Sen met with the Chinese Prime Minister 'to discuss a strengthening of cooperation' between the two 'on issues in the region and internationally which both parties are paying attention to'. ${ }^{172}$ It was subsequently announced that the government was to receive $\$ 600$ million of Chinese grant aid, to be used for 'electoral processes, health, education, clean water and wells' ${ }^{173}$ 


\section{Duterte's false hope in China}

Responding to a perceived lack of US commitment, President Duterte declared in September 2016 that upcoming war games to be held between the two countries would be the last, and that he would instead establish new alliances for trade with Russia and China. ${ }^{174}$ On 3 October 2016, Philippines President Rodrigo Duterte blasted the US during a speech in Manila, telling President Barack Obama that he could 'go to hell' for refusing to sell the Philippines weapons, which he confirmed he could readily receive from Russia or China. ${ }^{175}$ Duterte claimed that he would 'break up with America', and realign his country's foreign policy. ${ }^{176}$ In this same month, during a visit to China, President Duterte succeeded in securing $\$ 24$ billion in Chinese trade and investment commitments. ${ }^{177}$ China also offered the Philippines' military a $\$ 500$ million loan, with China's Foreign Minister hailing a 'golden period of fast development' between the two. ${ }^{178}$

This shift in the Philippines' China policy coincided with a presidential election in the US in late 2016. The election of Donald Trump as US President only served to enhance uncertainty in Southeast Asia over the US' role in the region, with concerns over whether America would 'move towards a parochial and even isolationist foreign policy', for which 'both sides of the Pacific would have to pay dearly'. ${ }^{179}$ Seeking to allay regional fears, US Secretary of Defence Jim Mattis criticized China's action in the South China Sea at the Shangri-La Dialogue in Singapore in June 2017, stating 'artificial island construction and indisputable militarization of facilities on features in international waters undermine regional stability'. ${ }^{180}$ Focusing his attention on China, Mattis stated that Chinese actions differed from other claimant states due to the "nature of its militarization ... its disregard for international law, its contempt for other nations' interests, and its efforts to dismiss non-adversarial resolution of issues'. ${ }^{181}$ China responded to say 'it was resolutely opposed' to the comments, and urged 'concerned parties to stop issuing irresponsible remarks'. ${ }^{182}$ The comments came one month before the US sailed a warship less than 12 miles from an island in the Paracels in a freedom of navigation demonstration, something China called 'a serious political and military provocation'. ${ }^{183}$

The Duterte Administration's hope that engagement with China would ameliorate tensions in the South China Sea has largely proved to be unfounded. Despite the brokering of a 'status quo' between the two states, with China purportedly agreeing to halt further expansion in the South China Sea, reports from November 2017 suggest that 
China has continued to develop facilities in the Paracel Islands, in addition to a military buildup in the Spratly Islands. ${ }^{184}$ At the ASEAN Summit held in Manila in November 2017, Duterte confirmed that 'the South China Sea is better left untouched, nobody can afford to go to war'. ${ }^{185}$ In the same month, the Philippines ordered its officials to halt construction of a shelter for Filipino fishermen on a sandbar in disputed waters, following a Chinese complaint that the construction constituted the occupation of a new feature. ${ }^{186}$ In the words of one former Filipino marine captain, 'this is part of Duterte's strategy of silence, inaction and subservience to China's actions in the South China Sea' ${ }^{187}$

\section{Vietnam struggles as sole vanguard state}

Meanwhile, Vietnam has been left to face China without its covanguard backing, with limited success. In June 2017, China demanded that Vietnam halt drilling by a subsidiary Spanish energy company, Repsol, off the southern Vietnamese coast. ${ }^{188}$ Pushing back against Chinese demands, Vietnam's Foreign Ministry spokeswoman Le Thi Thu Hang stated that 'Vietnam's petroleum-related activities take place in the sea entirely under the sovereignty and jurisdiction of Vietnam established in accordance with international law'. ${ }^{189}$ This position was not sustainable, however, with China reportedly threatening to attack Vietnamese bases in the Spratlys if it did not halt the drilling. ${ }^{190}$ China's harsh rhetoric paid off, with Vietnam forced to suspend the drilling project. Crucially, the US failed to respond to China's actions vis-à-vis Vietnam. Indeed, according to Hayton, the reason Vietnam capitulated to China was the realization that 'the Trump administration could not be relied upon to come to Hanoi's assistance in the event of a confrontation with China'. ${ }^{191}$ This was indicative of a general feeling across Southeast Asia, that 'the US is not prepared to put skin in the game', and that the US 'either does not understand or sufficiently care about the interests of its friends and potential partners in Southeast Asia to protect them against China'. ${ }^{192}$ This has 'left the region drifting in the direction of Beijing'. ${ }^{193}$

Relations with China soured further after Vietnam made an unsuccessful attempt to include a note on the need for a legally binding maritime code of conduct into the ASEAN Foreign Ministers joint communiqué in August 2017. ${ }^{194}$ The move infuriated China, which responded by cancelling a planned bilateral meeting. ${ }^{195}$ Chinese media accused Vietnam of attempting to 'sow seeds of discord', and of being 
a 'thief crying stop thief'. ${ }^{196}$ Recognizing its weak position compared to China, Vietnam has continued to seek external power support from the US, despite uncertainty regarding US commitment following the election of Donald Trump. In an August 2017 meeting between Secretary of Defense Jim Mattis and the Vietnamese Minister of National Defense Ngo Xuan Lich, it was confirmed that the US and Vietnam would deepen defence cooperation, including the expansion of maritime cooperation, and work towards arranging a visit from a US aircraft carrier in 2018, the first such visit since $1975 .{ }^{197}$

Chinese threats have not been solely directed towards Vietnam. In May 2017, prior to Vietnam's clash with China, Philippines President Rodrigo Duterte referenced a discussion he had with China's Xi Jinping over oil exploration in disputed waters. According to Duterte, he informed $\mathrm{Xi}$ that 'we intend to drill oil there, if it's yours, well, that's your view, but my view is, I can drill the oil'. ${ }^{198} \mathrm{Xi}$ reportedly responded: 'we're friends, we don't want to quarrel with you, we want to maintain the presence of warm relationship [sic], but if you force the issue, we'll go to war' ${ }^{199}$ In a damage limitation exercise, the Philippines Foreign Secretary Alan Peter Cayetano released his own interpretation of the meeting, stating 'I will not contradict the president's words. I'm just telling you ... my interpretation in that meeting is that, there was no bullying, no pushing around. It wasn't a threat ... it was more the threat of conflict will always be there if we do not dialogue'. ${ }^{200}$

\section{The future of interest convergence?}

With the Philippines' sovereignty in the South China Sea still being violated, despite improved relations with China, Duterte has been forced to reconsider his attitude towards the US. In October 2017, the Philippines' military chief described the US as the Philippines' 'number one ally', and announced a return to regular war games. ${ }^{201}$ Duterte is reported to have stated that his dispute with the Obama administration was 'water under the bridge', and that the Filipino leader wanted to pursue a closer relationship. ${ }^{202}$ Although the Philippines' military chief also stated that the Philippines would pursue closer defence ties with China, the move remains indicative of what could be a more permanent change in the Philippines' position. ${ }^{203}$

So far, this has been complicated by a lack of clarity over US intentions towards China and the Southeast Asian region under the Trump Administration. President Trump has oscillated between a 
combative stance with China over what he believes to be an unfair trade deficit between the two countries, to a conciliatory approach in the hope that China can pressure North Korea to halt its nuclear weapons programme. In what was undoubtedly an attempt to reassure regional allies, President Trump embarked on a 12-day tour of Asia in November 2017, to include stops at the Philippines and Vietnam. In Manila, Trump hailed his 'great relationship' with Duterte. ${ }^{204}$ In Vietnam, Trump made reference to the South China Sea dispute, stating that 'if I can help mediate or arbitrate, please let me know' ${ }^{205}$ This statement came after comments made at an APEC Summit in Vietnam, where Trump referred to China's 'territorial expansion'. ${ }^{206}$ However, Trump's decision to skip the East Asia Summit on the final day of the tour will have left other regional allies unsure of US commitment. ${ }^{207}$ As Thayer notes, the decision was an 'act of political vandalism' ${ }^{208}$ Thayer continued: 'the US claims the US is a resident power, China claims it is an outside power. Trump's actions will speak louder than his words'. ${ }^{209}$

The Trump Administration articulated a 'free and open Indo-Pacific' strategy in early 2018. US Secretary of State Mike Pompeo fleshed out this strategy in an Indo-Pacific Business Forum in July 2018. In doing so, he paid particular attention to defining the strategy's terms, where 'free' was defined as the ability of all regional states 'to be able to protect their sovereignty from coercion by other countries', in addition to 'good governance' and the maintenance of citizen 'fundamental rights and liberties'. ${ }^{210}$ An 'open' strategy was defined as the ability of all states to 'enjoy open access to seas and airways', including the 'peaceful resolution of territorial and maritime disputes', in addition to 'fair and reciprocal trade, open investment ... and improved connectivity to drive regional ties' ${ }^{211}$ Although the strategy does not name China directly, its focus on maritime security and the protection of state sovereignty leaves little doubt that the policy seeks to directly challenge China's regional dominance and maritime expansion.

While this strategy to counterbalance Chinese power may come as some consolation to the states of Southeast Asia, other aspects of Trump's regional policy may prove more unsettling. The strategy's emphasis on bilateral free trade deals reflects President Trump's rejection of multilateral coalitions. Under his 'America First' policy agenda, he withdrew the US from the TPP trade deal in January 2017, claiming the deal would benefit large corporations at the expense of American workers. This decision came as a blow to the regional states of Southeast Asia, raising questions over US continued commitment to the region. In comments made in April 2018, Singaporean Ambassador Tommy Koh stated that Trump's trade policies were 'a concern for 
the whole of Asia', confirming that 'all of us have benefited from free trade and all of us oppose protectionism so we're very concerned by the policies of the current administration in Washington'. ${ }^{212}$

President Trump's ensuing trade war with China, fuelled by accusations of currency manipulation and unfair trading practices, has only served to exacerbate these concerns. Asian states' reliance on regional supply chains make them particularly vulnerable to a full-scale trade war. Singapore's Prime Minister Lee Hsien Loong confirmed that any trade war would have a 'big, negative impact' on his country, with growth rates potentially halved. ${ }^{213}$ Donald Trump's subsequent decision to skip the 18-nation ASEAN Summit and APEC East Asia Summit in November 2018 only serves to undermine his strategy for the region. In the words of Oh Ei Sun, senior advisor at the Asian Strategy and Leadership Institute in Kuala Lumpur, Donald Trump's absence 'would doubtlessly solidify the impression that America has essentially abandoned its traditional presence in the Asia Pacific, not to mention the non-starter Indo-Pacific' ${ }^{214}$ China will be seeking to capitalize on this absence, with Xi Jinping planning to hold his own summit at APEC with a number of Pacific leaders. President Trump's trade war has confirmed the view held by many within China that the US seeks to limit its growth and expansion. This was confirmed in the People's Daily, which reported that the 'US' intention to disrupt China's development process has been thoroughly exposed'. ${ }^{215}$

For Kaplan, Donald Trump's trade policies have hindered, rather than helped US security strategy in the South China Sea. He argues that we should not "believe for a moment that the US can use trade as a lever against China in the South China Sea, where Beijing has a wellgrounded, long-term grand strategy, as opposed to Trump's zigzagging whims'. ${ }^{216}$ The contents of the 'Indo-Pacific' strategy suggest that the Trump Administration has finally realized the vital interests at stake in preventing China from securing a fait accompli in the region's waters. In reality, however, the protectionist and inconsistent nature of the Trump Administration's policies and actions risk alienating regional allies. As noted by Gupta, 'without an altogether more wholehearted embrace of the Asia's ASEAN-centred security multilateralism as well as deeper integration within the Asia-Pacific's emerging community-style economic order, the US will find itself relegated to the sidelines'. ${ }^{217}$ One unintended result would see Southeast Asian states forced to 'conclude separate understandings with China', in lieu of a strong commitment from the US. ${ }^{218}$

Meanwhile, ASEAN's struggle to coordinate a policy on the South China Sea has revived talks of the need for a legally binding code of 
conduct. As Storey notes, "more than a decade after it was signed, the DOC has yet to be even partially implemented and most of the claimants have violated the spirit of the agreement through unilateral and provocative actions'. ${ }^{219}$ It is for these reasons that ASEAN member states, in conjunction with interested external parties, have pushed for the creation of a legally binding declaration. ${ }^{220}$ In August 2017, foreign ministers from Australia, Japan and the US called on ASEAN and China to establish rules that are 'legally binding, meaningful, effective and consistent with international law', while they also 'voiced their strong opposition to coercive unilateral actions that could alter the status quo and increase tensions'. ${ }^{221}$ Singapore's foreign minister Vivian Balakrishnan echoed these sentiments, stating 'surely when we move into the COC [Code of Conduct], it has got to have some additional or significant legal effect'. ${ }^{222}$

Reports from mid-2017 suggest some progress on a framework for talks on a binding code of conduct. In August 2017, it was announced that "the regional bloc was ready to begin "substantive" negotiations on a code of conduct'. ${ }^{223}$ However, concerns remain amongst certain ASEAN claimants over the long-term interests China might be trying to secure through a more binding code. It was reported that ASEAN ministers had debated over how to respond to China, 'with Vietnam said to be strongly resisting an agreement on the framework for a code of conduct as pushed by Beijing'. ${ }^{224}$ Although the move to a more binding code could enhance stability, it is important to note that the parties have to date only agreed on a framework to begin negotiations, and there is no clarity on whether this would be a legally binding code, something which China still resists.

\section{Summary: 2016-present}

Since 2016, Southeast Asia has been in flux. Changing administrations in the Philippines and the US have contributed towards a changing China and South China Sea policy, with the Duterte administration preferring a policy of engagement with China, and the Trump administration seeking to cooperate with China on matters on the Korean peninsula. As a consequence, sovereignty disputes in the South China Sea have taken a backseat, something that has allowed China to continue its provocative actions in the region. Crucially, this lack of strong interest convergence between the US and the Philippines has caused the latter to continue to have its maritime sovereignty violated. Vietnam has had little success in resisting China on its own, 
and has received minimal backing from other members of ASEAN, which has remained divided. Evidence therefore suggests a lack of intra-ASEAN and external power interest convergence from the 2016 period onwards.

While it might be tempting to abandon vanguard state theory in this instance, events towards the end of 2017 suggest its continued utility. As China has continued to pursue its own interests in the region, at the expense of US and Filipino domestic policies, President Trump and Duterte have perhaps began to recognize the significance of the South China Sea as a domain where they too have vital interests to secure. With ASEAN making small, albeit limited, steps towards further negotiations on a DOC, and the Philippines, Vietnam and the US engaging in further cooperation, the vanguard states of Southeast Asia may well yet be able to resist violations to their sovereignty from an assertive China. What is clear, is that without this intra-ASEAN and external power interest convergence, the Philippines and Vietnam will continue to have their sovereignty violated.

\section{Theoretical assessment of the South China Sea dispute: interest convergence theory}

The South China Sea case is an example of ASEAN vanguard stateexternal power partial interest convergence. The Philippines and Vietnam, as the ASEAN states with the most compelling interest at stake in the South China Sea dispute, have increasingly had their sovereignty violated by an expansionist China since 1992. This has undoubtedly constituted a regional threat. The states have struggled to generate interest convergence, either with a powerful external actor with the capability to help prevent this sovereignty violation, or from regional neighbouring states. As this analysis has shown, it was not until 2012 that the US recognized the vital interests it had at stake in the South China Sea dispute, and was willing to act upon them to support the ASEAN vanguard states. ASEAN's preference for dialogue and confidence-building measures, and its inability to prevent China from using the Association to serve its own best interests, ${ }^{225}$ has left it fragmented and unable to mobilize support for its member states under threat.

From 2012 onwards, the ASEAN vanguard states actively sought great power security commitments from an increasingly engaged US. As Cruz De Castro confirms, 'confronted by China's preponderant economic and military power, the Philippines and Vietnam have 
no other recourse but to pursue a regional balance of power where the US remains a resident Pacific power and a major 21st century strategic player'. ${ }^{226}$ By engaging in such balancing behaviour, these small powers have hoped to 'win asymmetric conflicts', and 'affect the regional power equilibrium as they engage other powers outside of the system'. ${ }^{227}$ As momentum grew throughout 2015 and 2016, it seemed that the region was on the brink of a shift in power dynamics. Clearly, there existed symmetry of interests at this time. The US recognized in the Philippines and Vietnam like-minded states, hoping to curtail Chinese assertiveness in the South China Sea. If this ASEAN vanguard state-external power interest convergence had been able to continue, it is feasible that steps might have been taken to prevent any further ASEAN state sovereignty violation. As it stands, the growing interest convergence evident at this time was partial at best. Low levels of ASEAN support for the Philippines and Vietnam compounded this. As noted by Beeson, 'competing geo-political imperatives' ${ }^{228}$ have caused divisions amongst ASEAN, which as a result has left it struggling to maintain 'a sense of unity or collective purpose', ${ }^{229}$ with 'an effective, coherent, consistent and collective response to the challenge of China ... likely to prove beyond ASEAN's abilities'. ${ }^{230}$ This has left the Philippines 'especially exercised about ASEAN's inability to demonstrate solidarity in the face of a looming external threat from a much more powerful state'. ${ }^{231}$

A change of administrations in the Philippines and the US from 2016 onwards has served to derail this partial interest convergence. This period has seen a decrease in interest convergence, as these states have sought to secure varying regional interests. According to Heydarian, because President Duterte, 'is constitutionally the Philippines' chief diplomatic architect', his election 'represented nothing less than a volte-face for Philippines foreign policy'. ${ }^{232}$ The analysis presented here, while acknowledging the impact that domestic politics can play in such instances, shows that, whereas Duterte and Trump may well have initially sought to push their own nationalist agenda, systemic constraints imposed by the international system have increasingly prevented them from doing so. China, as a rising power, has continued to occupy and militarize territory also claimed by the Philippines. It has done so at the expense of US and Filipino preoccupation with domestic politics. Until the US and the Philippines recognize this fact, the argument presented here is that maritime sovereignty will continue to be violated.

For the purpose of this chapter, the Philippines and Vietnam are the ASEAN vanguard states, and the US the external power. This 
is not to say that there are not other interested parties to the South China Sea sovereignty dispute. The question might be raised as to why Malaysia and Brunei are not classed as vanguard states, in light of their own conflicting sovereignty claims with China. However, Malaysia and Brunei have pursued a different approach to territorial disputes with China. ${ }^{233}$ For Storey, 'Malaysia and Brunei's relatively relaxed positions over the South China Sea is partly due to cordial political ties and partly because of the luxury of distance from China compared to Vietnam and the Philippines'. ${ }^{234}$ As such, they can not be classed as vanguard states in this instance.

It is also true that external states such as Japan, India and Australia have their own interests in the region, and have lent economic and military support to the vanguard states accordingly. Despite a downturn in relations with the US, the Philippines 'continued its comprehensive engagement' with Japan, including a Philippine-Japan security partnership, maritime security cooperation, and the provision to the Philippines of Japanese military equipment and training. ${ }^{235}$ Japan has also sought to internationalize the dispute, particularly at multilateral forums, to enhance cooperation and capacity building with affected ASEAN states, and to coordinate policy with external powers such as the US, Australia and India. ${ }^{236}$ Vietnam has strengthened its defence relationship with India, including joint oil exploration, and the two elevated their relationship to that of a comprehensive strategic partnership in 2016. ${ }^{237}$ Undoubtedly, these regional states have an important role to play in the ASEAN vanguard state strategy to balance China in the South China Sea. However, these external states do not have the necessary power to balance China alone. Any effective counterbalance strategy requires the US, as the dominant power in the international system. As a Pacific power, the US has compelling interests at stake in preventing China from achieving regional dominance. However, until the US recognizes this, interest convergence and ASEAN resistance to sovereignty violation will remain elusive.

\section{Contrasting theoretical arguments}

All constructivist authors concede that the South China Sea dispute has tested ASEAN's norms. For Ba, the South China Sea dispute 'would in fact become the defining issue of ASEAN-China relations in the $1990 s^{\prime}{ }^{238}$ Similarly, Haacke argues that China, in seeking to enforce its territorial claims, has appeared to challenge ASEAN's norms on 
the non-use of force and restraint. ${ }^{239}$ Acharya admits that the South China Sea dispute 'posed a serious test of ASEAN's unity and its norms concerning the peaceful settlement of disputes' ${ }^{240}$ However, all authors still contend that ASEAN has upheld its norms and maintained its autonomy. For Haacke, China has 'incrementally allowed discussions on the Spratlys to deepen', and ASEAN has 'succeeded in allaying the remaining fears of the Chinese about the purpose of ASEAN's multilateral venture $[\mathrm{s}]{ }^{\prime} .{ }^{241}$ For $\mathrm{Ba}$, ASEAN rejected traditional alliances and security arrangements when confronted by China's challenge to ASEAN on the South China Sea dispute. ${ }^{242}$ Success has accompanied ASEAN's focus on socializing China through an enhanced security dialogue based on existing ASEAN frameworks, notably the ASEAN Regional Forum. ${ }^{243}$ Indeed, Acharya states that since the mid-1990s, China began 'to take a more supportive role in multilateralism and the ARF'. ${ }^{244}$ Specifically, 'ASEAN was able to secure an agreement from Beijing to conduct Sino-ASEAN multilateral consultations on security issues' ${ }^{245}$ In this view, 'China has come to acknowledge the usefulness of the ARF as the only multilateral venue available to it where it can discuss and share its security concerns and approach with Asia-Pacific countries'. ${ }^{246}$ Accordingly, ASEAN can also 'claim some success in dealing with China on the Spratlys issue'. ${ }^{247}$

The foregoing claims are difficult to reconcile with the actual record of Sino-ASEAN interaction on the South China Sea issue. ${ }^{248}$ ASEAN's multilateral diplomacy at the ARF and related ASEAN fora has consistently failed to make substantive headway on the dispute. Instead of ASEAN's norms socializing China, or enhancing regional unity, China has succeeded in dividing the ASEAN states and advancing its position in the South China Sea. Significantly, in 2012, the ASEAN states were unable to reach an agreement on the South China Sea, and failed to issue a joint communique for the first time in ASEAN's history. More importantly, ASEAN's maritime sovereignty continues to be violated by China. To counter this, regional states have increasingly sought external power security guarantees, most notably from the US. ${ }^{249}$ This leads us to examine other perspectives to explain ASEAN's record on regional autonomy.

Realist scholars take a very different view of ASEAN's regional autonomy. According to Leifer, the ASEAN aphorism of 'regional solutions for regional problems' is more 'a slogan serving a particular interest than an operational policy accepted and applied on a regional basis in any common interest'. ${ }^{250}$ In this view, the underlying behaviour of ASEAN actually conforms to the realist power-politics model. ${ }^{251}$ According to Jones, Khoo and Smith, the 'actual resolution of the 
South China Sea dispute remained stalemated in the ARF's preferred strategy of managing problems rather than solving them'. ${ }^{252}$ This stalemate 'serves China's rather than ASEAN's long-term strategic interest'. ${ }^{253}$ Rather than pursuing cooperative security through the ARF, there has been a 'classic recourse to hedging by weaker ASEAN states in an area of growing great power rivalry'. ${ }^{254}$ The dispute therefore demonstrates 'how more powerful actors can manipulate ASEAN's pliable norms to advance grand strategic interests'. ${ }^{255}$

For Leifer, a major problem is that in addition to a 'lack of political will' to resolve the dispute, there is an 'absence of any regional machinery for addressing the complex contention' in the South China Sea. ${ }^{256}$ Leifer argues that the South China Sea issue 'is symptomatic of the problem of regional order in a strategically-fused East and South East Asia, which lacks a security architecture'. ${ }^{257}$ Ultimately, Leifer doubts ASEAN's capability to effectively deal with the South China Sea dispute. Instead, 'the role of the US remains critical'. ${ }^{258}$ In this view, 'regional security would seem to require that such countervailing power, if it cannot be generated locally on a cooperative basis, should be available from an acceptable external source for which there is only one candidate'. ${ }^{259}$

Realist scholars offer a strong counter-argument to the constructivist view. ASEAN regional institutions have demonstrably been incapable of resolving the South China Sea dispute. Instead, China has succeeded in dividing the ASEAN states, and utilizing the existing institutional incoherence for its strategic advantage. These analysts' emphasis on the role of an external actor, the US, is indeed a necessary one. China's gains in the South China Sea have been predicated on an insufficiently robust US response. ${ }^{260}$ However, while the role of external powers remains a critical factor in the story, the fact is that regional states possess a greater capacity to secure their own interests than has been acknowledged by the realists cited previously. In theoretical terms, ASEAN states have greater autonomy, and hence state power, than they currently allow for. As this analysis shows, particularly in the post-2013 period, the Philippines and Vietnam actively sought, and partially secured, security commitments from the US, and a variety of external powers including Japan and India. This aspect of regional dynamics requires further theorizing.

Jones advances a perspective where regional autonomy is highly circumscribed, but in ways that depart from the realist understanding. ${ }^{261}$ For Jones, external 'intervention and the non-interference principle can be explained as the outcome of struggles between and within ASEAN's most powerful social forces'. ${ }^{262}$ However, this perspective 
appears unable to adequately account for the empirical record of SinoASEAN South China Sea interactions. In two important respects, the South China Sea dispute represents a challenge to the view that sovereignty is contingent upon the role of ASEAN domestic forces. First, the dispute involves key external powers, most notably China and the US. The interaction of these states with regional powers is integral to any analysis of the conflict. Second, it is not clear what impact, if any, ASEAN domestic groups have had on the conflict, with Jones' work omitting any discussion of the dispute. This raises questions about the relevance of the critical theory approach to an analysis of this central issue in ASEAN's post-Cold War international relations.

\section{Notes}

1 Content from this chapter originally co-authored with Nicholas Khoo, and published in Journal of Asian Security and International Affairs, Vol. 3 No. 2. Copyright 2016 C SAGE Publications India Private Limited, New Delhi. All rights reserved. Reproduced with the permission of the copyright holders and the publishers, SAGE Publications India Pvt. Ltd, New Delhi.

2 Ian Storey and Cheng-yi Lin, "Introduction", in The South China Sea Dispute: Navigating Diplomatic and Strategic Tensions, ed. Ian Storey and Lin Cheng-yi (Singapore: ISEAS - Yusof Ishak Institute, 2016), 1.

3 Storey and Lin, "Introduction", 8.

4 Robert D Kaplan, Asia's Cauldron: The South China Sea and the End of a Stable Pacific (New York: Random House, 2014), 14.

5 Donald E Weatherbee, International Relations in Southeast Asia: The Struggle for Autonomy. 2nd ed. (Maryland: Rowman \& Littlefield, 2009).

6 Ian Storey, "Rising Tensions in the South China Sea: Southeast Asian Responses", in The South China Sea Dispute: Navigating Diplomatic and Strategic Tensions, 147.

7 Southgate and Khoo, "Enter the Vanguard State", 228.

8 Andrew TH Tan, Security Strategies in the Asia-Pacific: The US' "Second Front” in Southeast Asia (New York: Palgrave Macmillan, 2011), 147.

9 Storey and Lin, "Introduction", 2.

10 Ian Storey, The US and ASEAN-China Relations: All Quiet on the Southeast Asian Front (Strategic Studies Institute, October 2007), 22-23.

11 Hasjim Djalal, "ASEAN Claimant's Position in the South China Sea", in Entering Unchartered Waters? ASEAN and the South China Sea, ed. Pavin Chachavalpongpun (Singapore: Institute Southeast Asian Studies, 2014), 70 .

12 Djalal, "ASEAN Claimant's Position in the South China Sea”, 70.

13 Djalal, "ASEAN Claimant's Position in the South China Sea", 69-70. 
14 Kaplan, Asia's Cauldron, 10.

15 Kaplan, Asia's Cauldron, 10.

16 Storey and Lin, "Introduction", 3.

17 Storey and Lin, "Introduction", 6.

18 Kaplan, Asia's Cauldron, 14.

19 Kaplan, Asia's Cauldron, 21.

20 Aza Wee Sile, "China sends missiles to contested South China Sea", CNBC News, 16 February 2016, https://www.cnbc.com/2016/02/16/ china-appears-to-have-deployed-missiles-on-woody-island-in-southchina-sea-us.html.

21 Jesse Johnson, “Beijing continuing 'steady pattern of militarization' in South China Sea", Japan Times, 24 February 2017, https://www. japantimes.co.jp/news/2017/02/24/asia-pacific/beijing-continuingsteady-pattern-militarization-south-china-sea/\#.WiQZnbSFjeQ.

22 Bill Hayton, The South China Sea: The Struggle for Power in Asia (New Haven, CT: Yale University Press, 2014), xvi.

23 "Law of the Territorial Sea and the Contiguous Zone of 25 February 1992", Article 2, United Nations Legislation and Treaties, http://www. un.org/depts/los/LEGISLATIONANDTREATIES/PDFFILES/ CHN_1992_Law.pdf.

24 Paul HB Godwin, "From Continent to Periphery: PLA Doctrine, Strategy and Capabilities Towards 2000”, The China Quarterly 146 (1996), 469.

25 Ang Cheng Guan, "The South China Sea Dispute Revisited”, Australian Journal of International Affairs 54, no. 2 (2000), 205.

26 Ang Cheng Guan, “The South China Sea Dispute Revisited”, 205.

27 Michael Richardson, "Chinese Gambit: Seizing Spratly Reef Without a Fight”, New York Times, 17 February 1995, http://www.nytimes. com/1995/02/17/news/17iht-sprat_1.html.

28 "Joint Statement of the RP-PRC Consultations on the South China Sea and on Other Areas of Cooperation, 9-10 August 1996", in International Law in East Asia, ed. Zou Keyuan and Jianfu Chen (New York: Routledge, 2016), 273.

29 Terry McCarthy, "Reef Wars", Time, 08 March 1999, http://content. time.com/time/world/article/0,8599,2054240,00.html.

30 Ang, "The South China Sea Dispute Revisited”, 208.

31 Richard Javad Heydarian, "Tragedy of Small Power Politics: Duterte and the Shifting Sands of Philippine Foreign policy", Asian Security, 13, no 3,5 .

32 Ang, "The South China Sea Dispute Revisited", 209.

33 Ang, "The South China Sea Dispute Revisited", 209-210.

34 Mark J. Valencia, China and the South China Sea Disputes, Adelphi Paper 298 (Oxford: International Institute for Strategic Studies, 1995), 48-49. 
35 Renato Cruz De Castro, "Adjusting to the Post-US Bases Era: The Ordeal of the Philippine Military's Modernization Program”, Armed Forces and Society 26, no. 1 (1999), 119.

36 Andrew Yeo, Activists, Alliances, and Anti-US Base Protests (Cambridge: Cambridge University Press, 2011), 154.

37 Cruz De Castro, "Adjusting to the Post-US Bases Era", 131.

38 "1992 ASEAN Declaration on the South China Sea." Adopted by the Foreign Ministers at the 25th ASEAN Ministerial Meeting, Manila, 22 July 1992, 35, http://www.assidmer.net/doc/Documents-on-ASEANand-South-China-Sea-as-of-June-2011.pdf.

39 Do Thanh Hai, Vietnam and the South China Sea: Politics, Security and Legality (New York: Routledge, 2017), 111.

40 "1999 Joint Communiqué of the 32nd ASEAN Ministerial Meeting", Singapore, 23-24 July 1999, 28, http://www.assidmer.net/doc/ Documents-on-ASEAN-and-South-China-Sea-as-of-June-2011.pdf.

41 Hai, Vietnam and the South China Sea, 112.

42 Hai, Vietnam and the South China Sea, 112.

43 Hai, Vietnam and the South China Sea, 113.

44 Hai, Vietnam and the South China Sea, 113.

45 "2002 Declaration on the Conduct of Parties in the South China Sea", Phnom Penh, 4 November 2002, 23, http://www.assidmer.net/doc/ Documents-on-ASEAN-and-South-China-Sea-as-of-June-2011.pdf.

46 "2002 Declaration on the Conduct of Parties in the South China Sea", 4 November 2002.

47 Robert C Beckman, "ASEAN and the South China Sea Dispute", in Entering Unchartered Waters? ASEAN and the South China Sea, 29.

48 Beckman, "ASEAN and the South China Sea Dispute", 29

49 Beckman, "ASEAN and the South China Sea Dispute", 30.

50 Storey, The US and ASEAN-China Relations, 6.

51 Thomas Lum, Wayne M Morrison and Bruce Vaughn, "CRIS Report for Congress: China's 'Soft Power' in Southeast Asia”, 04 January 2008, Order Code RL34310, CRS-9, https://fas.org/sgp/crs/row/RL34310.pdf.

52 Lum, Morrison and Vaughn, "CRIS Report for Congress”, 24-25.

53 Wikileaks Cable, "Latest Round of China-Vietnam Border Talks Break Down”, The Wikileaks Public Library of US Diplomacy, 26 January 2007, 07BEIJING598_a, https://wikileaks.org/plusd/cables/07BEIJING598_a. html.

54 Wikileaks Cable, "Sino-Vietnam Territorial Dispute Entangles Multiple Multinational Energy Firms", Wikileaks Public Library of US Diplomacy, 07 September 2007, 07HANOI1599_a, https://wikileaks.org/plusd/ cables/07HANOI1599_a.html. 
55 Wikileaks Cable, "Sino-Vietnam Territorial Dispute Entangles Multiple Multinational Energy Firms", 07HANOI1599_a.

56 Wikileaks Cable, "Sino-Vietnam Territorial Dispute Entangles Multiple Multinational Energy Firms”, 07HANOI1599_a.

57 Wikileaks Cables, "Patriotic HCMC and Hanoi Rallies Nevertheless Challenge GVN Sense of Order", Wikileaks Public Library of US Diplomacy, 21 December 2007, 07HOCHIMINHCITY1266_a, https://wikileaks. org/plusd/cables/07HOCHIMINHCITY1266_a.html.

58 Hai, Vietnam and the South China Sea, 166.

59 Aileen SP Baviera, "An ASEAN Perspective on the South China Sea" China-ASEAN Collision or China-US Hegemonic Competition?” in Entering Unchartered Waters? ASEAN and the South China Sea, 100.

60 David Morgan, "US says Chinese vessels harassed Navy ship", Reuters, 09 March 2009, https://www.reuters.com/article/us-usa-china-navy/us-says-chinese-vessels-harassed-navy-ship-idUSTRE52845A20090309.

${ }^{61}$ Michael D Swaine, "China's Assertive Behaviour. Part One: On Core Interests”, China Leadership Monitor, Carnegie Endowment for International Peace, 15 November 2010, 8.

62 Barry Wain, "The US position in the South China Sea", in Entering Unchartered Waters? ASEAN and the South China Sea, 254.

63 Edward Wong, "China Hedges Over Whether South China Sea Is a 'Core Interest' Worth War”, New York Times, 30 March 2011, http://www. nytimes.com/2011/03/31/world/asia/31beijing.html.

64 Wong, "China Hedges Over Whether South China Sea Is a 'Core Interest", 30 March 2011.

65 Wain, "The US position in the South China Sea", 249.

66 Whasun Jho and Soo A Chae, "Hegemonic Disputes and the Limits of the ASEAN Regional Forum”, Pacific Focus: Inha Journal of International Studies 29, no. 2 (2014), 246.

67 Wain, "The US position in the South China Sea", 257.

68 Wain, "The US position in the South China Sea", 257.

69 Wain, "The US position in the South China Sea", 256.

70 Wain, "The US position in the South China Sea", 258.

71 Wong, "China Hedges Over Whether South China Sea Is a 'Core Interest', 30 March 2011.

72 Wong, "China Hedges Over Whether South China Sea Is a 'Core Interest”, 30 March 2011.

73 Southgate and Khoo, "Enter the Vanguard State", 229.

74 Renato Cruz De Castro, "Facing up to China's Realpolitik Approach in the South China Sea Dispute: The Case of the 2012 Scarborough Shoal Stand-Off and its Aftermath", Journal of Asian Security 3, no. 2 (2016), 158. 
75 Jane Perlez, "Philippines and China Ease Tensions in Rift at Sea", New York Times, 18 June 2012, http://www.nytimes.com/2012/06/19/world/ asia/beijing-and-manila-ease-tensions-in-south-china-sea.html.

76 Cruz De Castro, "Facing up to China's Realpolitik Approach in the South China Sea Dispute”, 158.

77 Marga Ortigas, "Scarborough Shoal stand-off sparks protests", Al Jazeera, 13 May 2012, http://www.aljazeera.com/indepth/ features/2012/05/2012512191343212584.html.

78 Heydarian, "Tragedy of Small Power Politics", 8.

79 Cruz De Castro, "Facing up to China's Realpolitik Approach in the South China Sea Dispute”, 167.

80 Cruz De Castro, "Facing up to China's Realpolitik Approach in the South China Sea Dispute", 168.

81 Cruz De Castro, "Facing up to China's Realpolitik Approach in the South China Sea Dispute”, 168.

82 Kaplan, Asia's Cauldron, 128.

83 Carlyle A Thayer, "ASEAN, China and the Code of Conduct in the South China Sea”, SAIS Review of International Affairs 33, no. 2 (2013), 78.

84 Robert Sutter and Chin-hao Huang, "China-Southeast Asia Relations: China Gains and Advances in South China Sea", Comparative Connections 14, no. 3 (2012), 69.

85 Carlyle Thayer, "Vietnam's Defensive Diplomacy", Wall Street Journal, 19 August 2010, https://www.wsj.com/articles/SB10001424052748703 649004575438474083884494.

86 Kaplan, Asia's Cauldron, 62.

87 Kaplan, Asia's Cauldron, 63.

88 Renato Cruz De Castro, "The Philippines Confronts China in the South China Sea: Power Politics vs. Liberalism-Legalism”, Asian Perspective 39, no. 1 (2015), 72.

89 Tan, Security Strategies in the Asia-Pacific, 149.

90 "Remarks by President Obama to the Australian Parliament", The White House Office of the Press Secretary, Parliament House Canberra, Australia, November 17, 2011, https://obamawhitehouse.archives.gov/the-pressoffice/2011/11/17/remarks-president-obama-australian-parliament.

91 "Remarks by President Obama to the Australian Parliament", November 17, 2011.

92 Richard C Bush, "The Response of China's Neighbours to the US "Pivot" to Asia”, Brookings, 31 January 2012, https://www.brookings.edu/on-therecord/the-response-of-chinas-neighbors-to-the-u-s-pivot-to-asia/.

93 Ernest Bower and Derwin Pereira, "Convince ASEAN countries that US pivot to Asia is no empty promise", Straits Times, 21 April 2014, http:// 
www.straitstimes.com/opinion/convince-asean-countries-that-us-pivotto-asia-is-no-empty-promise.

94 Manuel Mogato, "US triples military aid to Philippines in 2012", Reuters, 03 May 2012, https://www.reuters.com/article/us-philippines-usa/u-striples-military-aid-to-philippines-in-2012-idUSBRE8420IU20120503.

95 Reuters, "US starts its first Agent Orange cleanup in Vietnam", 09 August 2012, https://www.reuters.com/article/us-vietnam-usaagentorange/u-s-starts-its-first-agent-orange-cleanup-in-vietnamidUSBRE87803K20120809.

96 Heydarian, "Tragedy of Small Power Politics", 8.

97 Heydarian, "Tragedy of Small Power Politics", 9.

98 Renato Cruz De Castro, "The Strategic Balance in East Asia and the Small Powers: The Case of the Philippines in the Face of the South China Sea Dispute", Pacific Focus: Inha Journal of International Studies 31, no. 1 (2016), 139.

99 "Republic of the Philippines Department of Foreign Affairs Manila: Notification and Statement of Claim”, No. 13-0211, 22 January 2013, https://www.dfa.gov.ph/images/UNCLOS/Notification\%20and\%20 Statement\%20of\%20Claim\%20on\%20West\%20Philippine\%20Sea.pdf.

100 "In the Matter of the South China Sea Arbitration before an Arbitral Tribunal Constituted Under Annex VII to the 1982 United Nations Convention on the Law of the Sea between the Republic of the Philippines and the People's Republic of China”, Permanent Court of Arbitration Award, PCA Case No. 2013-19, 12 July 2016, 2, https://pca-cpa.org/ wp-content/uploads/sites/175/2016/07/PH-CN-20160712-Award.pdf. 101 "In the Matter of the South China Sea Arbitration", PCA Case No. 201319, 12 July 2016, 3.

102 "In the Matter of the South China Sea Arbitration", PCA Case No. 201319, 12 July 2016, 3.

103 "In the Matter of the South China Sea Arbitration", PCA Case No. 201319, 12 July 2016, 1-2.

104 “Foreign Ministry Spokesperson Hong Lei’s Regular Press Conference on February 20, 2013”, Consulate-General of the People's Republic of China in Toronto, http://toronto.china-consulate.org/eng/fyrthhz/t1015425. htm.

105 "Position Paper of the Government of the People's Republic of China on the Matter of Jurisdiction in the South China Sea Arbitration Initiated by the Republic of the Philippines", Ministry of Foreign Affairs of the People's Republic of China, 7 December 2014, http://www.fmprc.gov. cn/mfa_eng/zxxx_662805/t1217147.shtml. 
106 "Position Paper of the Government of the People's Republic of China on the Matter of Jurisdiction in the South China Sea Arbitration Initiated by the Republic of the Philippines", 7 December 2014.

107 "Remarks by MOFA Spokesperson Le Hai Binh on the South China Sea Arbitration Case", Ministry of Foreign Affairs, 11 December 2014, http:// www.mofa.gov.vn/en/tt_baochi/pbnfn/ns141212143709.

108 "Remarks by MOFA Spokesperson Le Hai Binh on the South China Sea Arbitration Case", 11 December 2014.

109 “Foreign Ministry Spokesperson Hong Lei's Remarks on Vietnam's Statement on the Chinese Government's Position Paper on Rejecting the Jurisdiction of the Arbitral Tribunal Established at the Request of the Philippines for the South China Sea Arbitration", Ministry of Foreign Affairs of the People's Republic China, 12 December 2014, http://www. fmprc.gov.cn/mfa_eng/xwfw_665399/s2510_665401/t1218756.shtml.

110 "Remarks by President Obama and President Benigno Aquino III of the Philippines in Joint Press Conference", The White House Office of the Press Secretary, 28 April 2014, https://obamawhitehouse.archives.gov/ the-press-office/2014/04/28/remarks-president-obama-and-presidentbenigno-aquino-iii-philippines-joi.

111 The Guardian, "Obama says China bullying smaller nations in South China Sea row”, 10 April 2015, https://www.theguardian.com/world/2015/ apr/10/obama-says-china-bullying-smaller-nations-in-south-china-searow.

112 The Guardian, "Obama says China bullying smaller nations in South China Sea row", 10 April 2015.

113 Tang Siew Mun, "What is at stake for ASEAN?" ISEAS Yusof Ishak Institute: ASEAN Focus Special Issue on the South China Sea Arbitration, Responses and Implications, July 2016, 16, ISSN: 2424-8045, https://iseas. edu.sg/images/pdf/ASEANFocusSChinaSeaArbitration.pdf.

114 Tang, "What is at stake for ASEAN?" July 2016, 16.

115 “MFA Spokesman's comments in response to media queries on the Philippines' initiation of arbitration proceedings against China under Article 287 and V II of the 1982 United Nations Convention on the Law of the Sea (UNCLOS)", Permanent Mission of the Republic of Singapore, Ministry of Foreign Affairs, 23 January 2013, https://www. $\mathrm{mfa}$. gov.sg/content/mfa/overseasmission/asean/press_statements_ speeches/2013/201301/press_20130123.html.

116 “MFA Spokesman's comments in response to media queries on the Philippines' initiation of arbitration proceedings against China”, 23 January 2013.

${ }^{117}$ Jonathan Kaiman, "China accuses Vietnam of ramming its ships in South China Sea”, The Guardian, 8 May 2014, https://www.theguardian.com/ 
world/2014/may/08/china-accuses-vietnam-ships-south-china-sea-oilrig.

118 Kaiman, "China accuses Vietnam of ramming its ships in South China Sea”, 8 May 2014.

119 Jane Perlez, "China and Vietnam Point Fingers After Clash in the South China Sea”, New York Times, 27 May 2014, https://www.nytimes. com/2014/05/28/world/asia/vietnam.html.

${ }^{120}$ Jane Perlez, "China and Vietnam Point Fingers”, 27 May 2014.

${ }^{121}$ Jane Perlez, “China and Vietnam Point Fingers”, 27 May 2014.

122 David S Cloud, "Defense Secretary Ashton Carter warns Beijing on South China Sea island-building”, LA Times, 29 May 2015, http://www.latimes. com/nation/la-na-ashton-carter-china-20150529-story.html.

${ }^{123}$ Lynn Kuok, "The US FON program in the South China Sea”, Brookings Centre for East Asia Policy Studies, East Asia Policy Paper 9, June 2016, 15.

${ }^{124}$ Kuok, "The US FON program in the South China Sea", 15.

125 Kuok, "The US FON program in the South China Sea", 15-16.

126 Ashton Carter, "The US and Challenges to Asia-Pacific Security", The Shangri-La Dialogue Report, 30 May 2015, http://www.iiss.org/en/ publications/conference\%20proceedings/sections/shangri-la-aa36/theshangri-la-dialogue-2015-8842/sld15-05-plenary-1-e16c.

127 Katie Hunt and Kathy Quiano, "South China Sea: China building more islands?” CNN, 08 September 2016, http://edition.cnn.com/2016/09/08/ asia/south-china-sea-scarborough-shoal-philippines-china/index.html.

128 "Signing of Enhanced Defense Cooperaiton Agreement", US Embassy in the Philippines, 28 April 2014, https://ph.usembassy.gov/signingenhanced-defense-cooperation-agreement/.

129 Reuters, "Philippines offers eight bases to US under new military deal", 13 January 2016, https://www.reuters.com/article/us-philippines-usabases/philippines-offers-eight-bases-to-u-s-under-new-military-dealidUSKCNOUR17K20160113.

${ }^{130}$ Renato Cruz De Castro, "The Early Duterte Presidency in the Philippines”, Journal of Current Southeast Asian Affairs 35, no. 3 (2016), 140.

${ }^{131}$ Reuters, "Philippines offers eight bases to US under new military deal", 13 January 2016.

132 Philstar, "Full Text: Obama on South China Sea, defense alliance with Philippines", 18 November 2015, http://www.philstar.com/ headlines/2015/11/18/1523292/full-text-obama-south-china-seadefense-alliance-philippines.

133 Philstar, "Full Text: Obama on South China Sea", 18 November 2015.

${ }^{134}$ Raul Dancel, "Nothing provocative in what the US is doing, says Aquino", Straits Times, 28 October 2015, http://www.straitstimes.com/asia/se-asia/ nothing-provocative-in-what-the-us-is-doing-says-aquino. 
135 CNN Philippines, "Philippines eyes record P25B defense spending for 2016”, 21 July 2015, http://cnnphilippines.com/news/2015/07/21/ Philippines-proposes-record-P25B-defense-spending-in-2016.html.

136 Yeganeh Torbati, "US announces ramped-up military presence in Philippines", Reuters, 14 April 2016, https://www.reuters.com/article/ us-southchinasea-philippines-carter/u-s-announces-ramped-up-militarypresence-in-philippines-idUSKCNOXBOQY.

137 "Remarks by President Obama and President Truong Tan Sang of Vietnam after Bilateral Meeting", The White House Office of the Press Secretary, 25 July 2013, https://obamawhitehouse.archives.gov/the-pressoffice/2013/07/25/remarks-president-obama-and-president-truong-tansang-vietnam-after-bila.

138 "Fact Sheet: US-Vietnam Comprehensive Partnership", US Embassy and Consulate in Vietnam, 16 December 2013, https://vn.usembassy. gov/20131216factsheet-us-vietnam-comprehensive-partnership/.

139 "Joint statement by President Barack Obama of the US of America and President Truong Tan Sang of the Socialist Republic of Vietnam", The White House Office of the Press Secretary, 25 July 2013, https:// obamawhitehouse.archives.gov/the-press-office/2013/07/25/jointstatement-president-barack-obama-united-states-america-and-preside.

140 "US-Vietnam Joint Vision Statement", US Embassy and Consulate in Vietnam, 07 July 2015, https://vn.usembassy.gov/u-s-vietnam-jointvision-statement/.

141 "Remarks by President Obama and President Quang of Vietnam in Joint Press Conference", The White House Office of the Press Secretary, 23 May 2016, https://obamawhitehouse.archives.gov/the-pressoffice/2016/05/23/remarks-president-obama-and-president-quangvietnam-joint-press.

142 Remarks by President Obama and President Quang of Vietnam in Joint Press Conference", The White House, 23 May 2016.

143 Tiffany Ap, Jennifer Rizzo and Kevin Liptak, "Obama lifts US arms ban on Vietnam”, CNN Politics, 24 May 2016, http://edition.cnn. com/2016/05/23/politics/obama-vietnam-trip/index.html.

144 Straits Times, "Philippines and Vietnam to be 'strategic partners", 04 September 2015, http://www.straitstimes.com/asia/philippines-andvietnam-to-be-strategic-partners.

${ }^{145}$ Kristine Angeli Sabillo, "PH, Vietnam ink closer defense ties", Inquirer, 17 November 2015, http://globalnation.inquirer.net/131451/phvietnam-sign-statement-on-strategic-partnership-amid-disputes-in-southchina-sea.

146 Sabillo, “PH, Vietnam ink closer defense ties”, 17 November 2015. 
147 "Joint Statement of the US-ASEAN Special Leaders' Summit: Sunnylands Declaration", The White House Office of the Press Secretary, 16 February 2016, https://obamawhitehouse.archives.gov/the-pressoffice/2016/02/16/joint-statement-us-asean-special-leaders-summitsunnylands-declaration.

148 Jeff Mason and Bruce Wallace, "Obama, ASEAN discuss South China Sea tensions, but no joint mention of China", Reuters, 16 February 2016, https://www.reuters.com/article/us-usa-asean/obama-aseandiscuss-south-china-sea-tensions-but-no-joint-mention-of-chinaidUSKCNOVP1F7.

149 Cruz De Castro, "The Philippines Confronts China in the South China Sea", 72.

150 "PM Lee Hsien Loong's interview with Wall Street Journal (WSJ) on 29 March 2016”, Prime Minister's Office Singapore, 29 March 2016, http://www.pmo.gov.sg/newsroom/pm-lee-hsien-loongs-interview-wallstreet-journal-wsj.

151 "PM Lee Hsien Loong's interview with Wall Street Journal (WSJ)", 29 March 2016.

${ }^{152}$ Heydarian, "Tragedy of Small Power Politics", 1.

${ }^{153}$ Heydarian, "Tragedy of Small Power Politics", 1.

154 Al Jazeera, "Rodrigo Duterte: 'I don't care about human rights", 08 August 2016, http://www.aljazeera.com/news/2016/08/rodrigo-duterte-humanrights-160806211448623.html.

155 "Press Release: The South China Sea Arbitration (The Republic of the Philippines v. The People's Republic of China", Permanent Court of Arbitration, The Hague, 12 July 2016, https://pca-cpa.org/wp-content/ uploads/sites/175/2016/07/PH-CN-20160712-Press-Release-No-11English.pdf, 1-2.

156 "Press Release: The South China Sea Arbitration", 12 July 2016, 2.

157 "Press Release: The South China Sea Arbitration", 12 July 2016, 2.

158 "Press Release: The South China Sea Arbitration", 12 July 2016, 2.

$159 \mathrm{Jim}$ Gomez, "Duterte says he'll set aside sea feud ruling against China”, Philstar, 17 December 2016, http://www.philstar.com/ headlines/2016/12/17/1654340/duterte-says-hell-set-aside-sea-feudruling-against-china.

${ }^{160}$ Gomez, "Duterte says he'll set aside sea feud ruling against China", 17 December 2016.

161 Gomez, "Duterte says he'll set aside sea feud ruling against China”, 17 December 2016.

162 Richard Javad Heydarian, "Has Duterte's China engagement backfired?" Asia Times, 14 July 2017, http://www.atimes.com/article/dutertes-chinaengagement-backfired/. 
163 Cruz De Castro, “The Early Duterte Presidency in the Philippines”, 147.

${ }^{164}$ Christopher Bodeen, "Recent developments surrounding the South China Sea dispute”, Philstar, 23 August 2017, http://www.philstar.com/ headlines/2016/08/23/1616443/recent-developments-surroundingsouth-china-sea-dispute.

165 Cruz De Castro, “The Early Duterte Presidency in the Philippines”, 140.

166 Shi Jiangtao, "Has Beijing really 'turned the page' on South China Sea ruling?" South China Morning Post, 09 September 2016, http://www.scmp. com/news/china/diplomacy-defence/article/2018038/has-beijing-reallyturned-page-south-china-sea-ruling.

167 "Turning Vision Into Reality For a Dynamic ASEAN Community", Chairman's Statement of the 28th and 29th ASEAN Summits, Vientiane, 6-7 September 2016, http://asean.org/storage/2016/08/FinalChairmans-Statement-of-the-28th-and-29th-ASEAN-Summits-rev-fin. pdf.

${ }^{168}$ Manuel Mogato, Michael Martina, and Ben Blanchard, "ASEAN Deadlocked on South China Sea, Cambodia Blocks Statement”, Reuters, 25 July 2016, https://www.reuters.com/article/us-southchinasea-rulingasean/asean-deadlocked-on-south-china-sea-cambodia-blocks-statementidUSKCN1050F6.

${ }^{169}$ Mogato, Martina \& Blanchard, "ASEAN Deadlocked on South China Sea", 25 July 2016.

170 "Joint Statement of the Foreign Ministers of ASEAN Member States and China on the Full and Effective Implementation of the Declaration of the Conduct of Parties in the South China Sea", The Association of Southeast Asian Nations, July 2016, http://asean.org/storage/2016/07/ Joint-Statement-on-the-full-and-effective-implementation-of-the-DOCFINAL.pdf.

171 Ananth Baliga and Vong Sokhend, "Cambodia again blocks ASEAN statement on South China Sea", The Phnom Penh Post, 25 July 2016, http://www.phnompenhpost.com/national/cambodia-again-blocksasean-statement-south-china-sea.

172 Khmer Times, "China Gives \$600 Million After South China Sea Support", 15 July 2016, http://www.khmertimeskh.com/news/27292/china-gives-600-million-after-south-china-sea-support/.

173 Khmer Times, "China Gives \$600 Million After South China Sea Support."

${ }^{174}$ Martin Petty, "Duterte declares upcoming Philippine-U.S. war games 'the last one”", Reuters, 28 September 2016, https://www.reuters.com/article/ us-philippines-duterte/duterte-declares-upcoming-philippines-u-s-wargames-the-last-one-idUSKCN11Y1ZI.

175 Martin Petty, "Philippine leader tells Obama 'to go hell', says can buy arms from Russia, China”. Reuters, 04 October 2016, http://www.reuters. 
com/article/us-philippines-duterte-arms/philippine-leader-tells-obamago-to-hell-says-can-buy-arms-from-russia-china-idUSKCN12414A?utm_ content=bufferb48b7\&utm_medium $=$ social\&utm_source $=$ twitter. com\&utm_campaign=buffer.

176 Petty, "Philippine leader tells Obama 'to go hell”, 04 October 2016.

177 Heydarian, "Tragedy of Small Power Politics", 13.

178 Heydarian, “Has Duterte's China engagement backfired?” 14 July 2017.

179 Derwin Periera, "After Trump victory, uncertainty in Asia. If America retreats, will it be China to the fore?" Straits Times, 09 November 2016, http://www.straitstimes.com/opinion/after-trump-victory-uncertaintyin-asia-if-america-retreats-will-it-be-china-to-the-fore.

180 "Remarks by Secretary Mattis at Shangri-La Dialogue", US Department of Defense, 03 June 2017, https://www.defense.gov/News/Transcripts/ Transcript-View/Article/1201780/remarks-by-secretary-mattis-atshangri-la-dialogue/.

181 "Remarks by Secretary Mattis at Shangri-La Dialogue", US Department of Defense, 03 June 2017.

${ }^{182}$ Reuters, "China upset at Mattis' 'irresponsible remarks' on South China Sea”, 05 June 2017, https://www.reuters.com/article/us-asia-securitychina/china-upset-at-mattis-irresponsible-remarks-on-south-china-seaidUSKBN18W00U.

183 The Guardian, “'Serious military provocation' : China angered by US presence in South China Sea”, 03 July 2017, https://www.theguardian. com/world/2017/jul/03/serious-military-provocation-china-angered-byus-presence-in-south-china-sea.

${ }^{184}$ Japan Times, "As attention focuses on North Korean threat, Beijing quietly expanding South China Sea militarization”, 01 November 2017, https://www.japantimes.co.jp/news/2017/11/01/asia-pacific/attentionfocuses-north-korea-threat-beijing-quietly-expanding-south-china-seamilitarization/\#.WiazWLSFjeQ.

${ }^{185} R T$, “'We can't afford war': Duterte recommends leaving South China Sea alone, Trump offers mediation", 12 November 2017, https://www. rt.com/news/409620-duterte-war-south-china-sea/.

${ }^{186}$ Felipe Villamor, "Philippines Halts Work in South China Sea, in a Bid to Appease Beijing”, The New York Times, 08 November 2017, https://www. nytimes.com/2017/11/08/world/asia/philippines-south-china-sea.html.

187 Villamor, "Philippines Halts Work in South China Sea, in a Bid to Appease Beijing”, 08 November 2017.

${ }^{188}$ My Pham, "Vietnam pushes back after threats from Beijing over drilling in the South China Sea", Business Insider, 28 July 2017, http://www. businessinsider.com/r-vietnam-says-others-should-respect-its-right-todrill-for-south-china-sea-oil-2017-7. 
189 Pham, "Vietnam pushes back after threats from Beijing over drilling in the South China Sea”, 28 July 2017.

190 Bill Hayton, "South China Sea: Vietnam halts drilling after 'China threats”, BBC News, 24 July 2017, http://www.bbc.com/news/worldasia-40701121.

${ }^{191}$ Bill Hayton, "The Week Donald Trump Lost the South China Sea", Foreign Policy, 31 July 2017, http://foreignpolicy.com/2017/07/31/theweek-donald-trump-lost-the-south-china-sea/.

192 Hayton, "The Week Donald Trump Lost the South China Sea”, 31 July 2017.

${ }^{193}$ Hayton, "The Week Donald Trump Lost the South China Sea”, 31 July 2017.

194 Bhavan Jaipragas, "ASEAN and China have moved on...Didn't Vietnam get the memo?" South China Morning Post, 13 August 2017, http://www. scmp.com/week-asia/geopolitics/article/2106469/asean-and-china-havemoved-ondidnt-vietnam-get-memo.

195 Jaipragas, “ASEAN and China have moved on”, 13 August 2017.

196 Jaipragas, “ASEAN and China have moved on”, 13 August 2017.

197 "Readout of Secretary Mattis' Meeting with Vietnamese Minister of National Defense Lich”, US Department of State Release No. NR-285-17, 09 August 2017, https://www.defense.gov/News/News-Releases/NewsRelease-View/Article/1272572/readout-of-secretary-mattis-meetingwith-vietnamese-minister-of-national-defens/.

198 Manuel Mogato, "Duterte says China's Xi threatened war if Philippines drills for oil”, Reuters, 19 May 2017, https://www.reuters.com/article/ us-southchinasea-philippines-china/duterte-says-chinas-xi-threatenedwar-if-philippines-drills-for-oil-idUSKCN18F1DJ.

199 Mogato, "Duterte says China's Xi threatened war if Philippines drills for oil”, 19 May 2017.

200 Ina Andolong, "Cayetano: China did not bully PH with threat", CNN, 23 May 2017, http://cnnphilippines.com/news/2017/05/22/cayetanochina-did-not-bully-PH.html.

201 Channel News Asia, "Philippines hails US as top ally, welcomes war games", 05 October 2017, http://www.channelnewsasia.com/news/asiapacific/ philippines-hails-us-as-top-ally--welcomes-war-games-9282364.

202 Channel News Asia, "Philippines hails US as top ally, welcomes war games", 05 October 2017.

203 Channel News Asia, "Philippines hails US as top ally, welcomes war games", 05 October 2017.

204 Oliver Holmes, “Trump hails 'great relationship' with Philippines' Duterte”, The Guardian, 13 November 2017, https://www.theguardian. 
com/us-news/2017/nov/13/trump-hails-great-relationship-withphilippines-duterte.

${ }^{205}$ Shi Jiangtao and Liu Zhen, "Better left untouched': Philippines and Vietnam wary of Trump offer to mediate South China Sea disputes", South China Morning Post, 12 November 2017, http://www.scmp.com/ news/china/diplomacy-defence/article/2119551/better-left-untouchedphilippines-and-vietnam-wary.

206 Jiangtao and Zhen, “'Better left untouched': Philippines and Vietnam wary of Trump offer to mediate South China Sea disputes", 12 November 2017.

207 Oliver Holmes, "Trump skips East Asia Summit on final day of 12-day tour", The Guardian, 14 November 2017, https://www.theguardian.com/ us-news/2017/nov/14/donald-trump-skips-east-asia-summit-on-finalday-of-12-day-tour.

${ }^{208}$ Holmes, "Trump skips East Asia Summit on final day of 12-day tour", 14 November 2017.

${ }^{209}$ Holmes, "Trump skips East Asia Summit on final day of 12-day tour", 14 November 2017.

${ }^{210}$ Remarks on "America's Indo-Pacific Economic Vision" by Michael Pompeo, Indo Pacific Business Forum, Washington DC, US Department of State, July 30, 2018, https://www.state.gov/secretary/ remarks/2018/07/284722.htm.

${ }^{211}$ Remarks on "America's Indo-Pacific Economic Vision”, US Department of State, July 30, 2018.

${ }^{212}$ Nyshka Chandran, "Even if Trump wants to renegotiate the TPP, members may not bite, says Singapore official", CNBC, 18 April 2018, https://www.cnbc.com/2018/04/18/singapore-ministry-of-foreignaffairs-tommy-koh-on-the-trans-pacific-partnership.html.

${ }^{213}$ John Geddie, "Trump's overture to emerging Asia drowned out by trade war", Reuters, 02 August 2018, https://www.reuters.com/article/us-usatrade-asean/trumps-overture-to-emerging-asia-drowned-out-by-tradewar-idUSKBN1KN090.

${ }^{214}$ Joshua Gallu, "Trump's ASEAN summit snub fuels doubts about US commitment", The Sydney Morning Herald, 02 September 2018, https:// www.smh.com.au/world/asia/trump-s-asean-summit-snub-fuels-doubtsabout-us-commitment-20180902-p5019z.html.

215 Anna Fifield, "China thinks the trade war isn't really about trade", The Washington Post, 24 September 2018, https://www.washingtonpost. com/world/asia_pacific/china-thinks-the-trade-war-isnt-really-abouttrade/2018/09/23/67c7b0ec-bb51-11e8-b1c5-7a2126bc722c_story. html?utm_term $=. c 7$ ccbf1 aaa 77 . 
216 Robert D Kaplan, "How President Trump is helping Beijing win in the South China Sea”, The Washington Post, 09 October 2018, https:// www.washingtonpost.com/news/global-opinions/wp/2018/10/09/ how-president-trump-is-helping-beijing-win-in-the-south-chinasea/?noredirect $=$ on\&utm_term $=.556 \mathrm{cb} 534 \mathrm{ba} 9 \mathrm{e}$.

217 Sourabh Gupta, "China scores with ASEAN play as Trump's America loses its way in South China Sea”, South China Morning Post, 03 August 2018, https://www.scmp.com/week-asia/geopolitics/article/2158203/ china-scores-asean-play-trumps-america-loses-its-way-south.

218 Kaplan, "How President Trump is helping Beijing win in the South China Sea”, The Washington Post, 09 October 2018.

219 Storey, "Rising Tensions in the South China Sea", 155.

${ }^{220}$ Manuel Mogato and Christian Shepherd, "Australia, Japan, U.S. call for South China Sea code to be legally binding”, Reuters, 07 August 2017, https://www.reuters.com/article/us-asean-philippines-southchinaseaidUSKBN1ANOTU.

${ }^{221}$ Mogato and Shepherd, "Australia, Japan, U.S. call for South China Sea code to be legally binding”, 07 August 2017.

${ }^{222}$ Mogato and Shepherd, "Australia, Japan, U.S. call for South China Sea code to be legally binding”, 07 August 2017.

${ }^{223}$ Radio Free Asia, "ASEAN, Beijing Agree to Talks on South China Sea Code", 06 August 2017, http://www.rfa.org/english/news/china/aseanscs-08062017182346.html.

${ }^{224}$ Radio Free Asia, "ASEAN, Beijing Agree to Talks on South China Sea Code", 06 August 2017.

225 Jones and Smith, "Making Process, Not Progress", 150.

226 Cruz De Castro, "The Strategic Balance in East Asia and the Small Powers", 128.

227 Cruz De Castro, "The Strategic Balance in East Asia and the Small Powers", 130.

228 Beeson, "Can ASEAN Cope with China?" 7.

229 Beeson, "Can ASEAN Cope with China?" 6.

${ }^{230}$ Beeson, "Can ASEAN Cope with China?" 6-7.

231 Beeson, "Can ASEAN Cope with China?" 21.

${ }^{232}$ Heydarian, "Tragedy of Small Power Politics",1.

233 Storey, "Rising Tensions in the South China Sea", 151.

234 Storey, "Rising Tensions in the South China Sea", 151.

235 Cruz De Castro, "The Early Duterte Presidency in the Philippines", 153-154.

${ }^{236}$ Ian Storey, "Japan's maritime security interests in Southeast Asia and the South China Sea dispute", Political Science 65, no. 2 (2013), 138. 
237 Viet Nam News, "Viet Nam, India hold strategic talks", 25 October 2017, http://vietnamnews.vn/politics-laws/416212/viet-nam-india-holdstrategic-talks.html\#4vmrZtxelGI35uu7.97.

$238 \mathrm{Ba},[$ Re]Negotiating East and Southeast Asia, 161.

${ }^{239}$ Haacke, ASEAN's Diplomatic and Security Culture, 122-123.

240 Acharya, Constructing a Security Community in Southeast Asia, 157.

${ }^{241}$ Haacke, ASEAN's Diplomatic and Security Culture, 125-126.

${ }^{242} \mathrm{Ba},[$ Re]Negotiating East and Southeast Asia, 176-177.

${ }^{243} \mathrm{Ba},[R e]$ Negotiating East and Southeast Asia, 176-177.

244 Acharya, Constructing a Security Community in Southeast Asia, 211.

245 Acharya, Constructing a Security Community in Southeast Asia, 158.

246 Acharya, Constructing a Security Community in Southeast Asia, 211.

247 Acharya, Constructing a Security Community in Southeast Asia, 158.

${ }^{248}$ M. Taylor Fravel, "China's Strategy in the South China Sea”, Contemporary Southeast Asia 33, no. 3 (2011), 292-319.

249 Tan, Security Strategies in the Asia-Pacific, 149.

${ }^{250}$ Michael Leifer, "Regional solutions to regional problems?" in Towards Recovery in Pacific Asia, eds. G Segal and D Goodman (London: Routledge, 2000), 108.

251 Jones and Smith, “ASEAN's Imitation Community", 102.

252 David Jones, Nicholas Khoo and MLR Smith, Asian Security and the Rise of China: International Relations in an Age of Volatility (Cheltenham: Edward Elgar, 2013), 111.

253 Jones, Khoo and Smith, Asian Security and the Rise of China, 111.

${ }^{254}$ Jones, Khoo and Smith, Asian Security and the Rise of China, 112.

255 Jones, Khoo and Smith, Asian Security and the Rise of China, 113.

${ }^{256}$ Michael Leifer, "Stalemate in the South China Sea", in Perspectives on the Conflict in the South China Sea, ed. K Snildal (Oslo: Centre for Development and the Environment, 1999), 7-8.

257 Leifer, "Stalemate in the South China Sea", 8.

${ }^{258}$ Leifer, "Stalemate in the South China Sea", 135.

${ }^{259}$ Leifer, "Stalemate in the South China Sea", 135.

${ }^{260}$ Jones and Smith, "Constructing Communities", 179.

${ }^{261}$ Jones, ASEAN, Sovereignty and Intervention in Southeast Asia.

${ }^{262}$ Jones, ASEAN, Sovereignty and Intervention in Southeast Asia, 2. 



\section{The Future of ASEAN Sovereignty?}

The primary purpose of this book is to construct an explanation, rooted in a realist theoretical perspective, that more convincingly explains the dynamics of ASEAN state resistance to sovereignty violation. In this respect, one question is of particular importance: when has ASEAN state resistance to sovereignty violation succeeded, and when has it failed? This question has been answered with reference to the concept of an ASEAN vanguard state, which is defined as the ASEAN state with the most compelling interests at stake in a given issue. In determining the dynamics of ASEAN resistance to sovereignty violation, two variables are the focus of analysis: Interest convergence and success of resistance to sovereignty violation. As has been argued, a convergence in interests between an ASEAN vanguard state and an external actor accounts for the success of ASEAN vanguard state resistance to sovereignty violation (see Figure 1). Conversely, an absence of convergence accounts for the failure of ASEAN vanguard state resistance to sovereignty violation.

Four case studies were chosen for analysis. These case studies were selected to test the book's central claims and to evaluate them against existing theoretical perspectives. In advancing a realist theoretical approach, the study aims to defend the continued applicability of traditional international relations theory to the field of Southeast Asian regionalism. Analysis began with the underlying premise that the study of interest convergence can yield considerable utility to the field of Southeast Asian international relations. This chapter will summarize the book's findings, evaluating contending explanations for sovereignty violation in Southeast Asia, including those based on constructivist theory, realist theory and critical theory. Our preferred alternative, vanguard state theory, is offered as a more persuasive explanation. In doing so, it will make a strong case for a realist approach to the study of Southeast Asia. 


\section{Contending explanations for sovereignty violation in Southeast Asia}

Constructivist theorists advocate a perspective that strongly emphasizes ASEAN's autonomy and ability to uphold regional order despite challenges. ${ }^{1}$ This perspective rests on collective understandings and outcomes, interaction, and an abiding adherence to norms. The intervening role of external powers and their effect on domestic structures is largely downplayed or ignored. For Acharya, ASEAN norms have a transformative impact, regulating state behaviour, redefining state interests and constituting state identities. ${ }^{2}$ By emphasizing the role of 'regionalism', ${ }^{3}$ Acharya shows how regional cooperation has played a central role in shaping the modern Southeast Asian identity. ${ }^{4}$ Haacke explores the origins and development of a set of norms conceptualized as a diplomatic and security culture. For Haacke, a process of 'mutual recognition and reconciliation's was crucial to the emergence of regional norms, including norms of sovereign equality and non-intervention. ${ }^{6}$ For Ba, ideas about Southeast Asia's 'division and foreign intervention' find expression in 'ideas of resilience and "One Southeast Asia."”7

An assessment of constructivist theorizing with respect to our case studies highlights a number of limitations. Analysis began with Indonesia's invasion of East Timor in 1975. It is surprising that such an important case study is largely absent from the constructivist literature on ASEAN. This is significant, as it represents a hard case for constructivists. If they are able to demonstrate that the variables they focus on can explain the empirical record, they will have secured a major point against alternative theoretical approaches to understanding ASEAN. As it stands, Indonesia's invasion represents a direct challenge to the view that a strong ASEAN norm of non-interference exists. It would also appear to contradict the view that ASEAN's norms and institutions have a largely positive impact on state behaviour. Indonesia could have pushed for East Timor's admission into ASEAN and attempted to socialize it, rather than choosing to invade. That it did not do so raises serious questions about the importance attributed to ASEAN's norms by one of ASEAN's largest and most prominent states.

In respect to our second case, constructivists interpret the Third Indochina War as a challenge to ASEAN norms, cohesion and unity. ${ }^{8}$ These theorists continue to maintain that shared ideas and the importance of regional unity kept the states working together. ${ }^{9}$ In Acharya's view, the conflict 'motivated ASEAN members to overcome conflicting security interests and territorial disputes within 
the grouping, thereby moving it further on the path towards a security community'. ${ }^{10}$ However, the evidence presented here suggests that this position over-estimates the role of ideas and norms, neglects a host of other factors, and elevates the role of ASEAN, even while systematically downplaying that of external powers'. This produces an inaccurate portrayal of the conflict and its impact on the region.

Our third case is the humanitarian crisis that devastated East Timor in 1999. Generally speaking, constructivist theorists place significant emphasis on ASEAN autonomy, and 'regional solutions for regional problems, with minimal intervention by outside powers' ${ }^{11}$ However, evidence presented in this chapter shows that ASEAN was incapable of adhering to this norm. All the authors reviewed here frame the East Timor crisis with respect to the norm of non-interference. Acharya contends that ASEAN's 'reluctance to dilute its non-interference doctrine', prevented the ASEAN states from providing an effective response to the humanitarian crisis in East Timor in $1999 .{ }^{12}$ However, this approach overlooks the way in which ASEAN state adherence to non-interference exacerbated regional instability. By adhering to the non-intervention norm, these states effectively invited external intervention into the region. In doing so, they contravened the ASEAN norm of regional autonomy.

Our fourth case is the South China Sea dispute. While all authors argue that this dispute has tested ASEAN's norms, they maintain that the Association has had some success in socializing China through multilateral forums such as the ARF ${ }^{13}$ However, these claims are difficult to reconcile with the actual record of Sino-ASEAN interaction on the South China Sea issue. ${ }^{14}$ ASEAN's multilateral diplomacy at the ARF has consistently failed to make substantive headway on the dispute. Instead of ASEAN's norms socializing China, or enhancing regional unity, China has succeeded in dividing the ASEAN states and advancing its position in the South China Sea. To counter this, regional states have increasingly sought external power security guarantees, most notably from the US. ${ }^{15}$ These flaws, when taken together, significantly limit constructivism as an effective account of Southeast Asian sovereignty violation.

\section{Realist theory}

Realist theorists emphasize ASEAN's lack of autonomy and reliance on external actors' sufferance. For Leifer, regional organizations have 'reflected the condition of the more important regional relationships 
and, in particular, that between the US and China'. ${ }^{16}$ This has made achieving regional solutions for regional problems 'more a myth than a valid aspiration'. ${ }^{17}$ For Jones and Smith, ASEAN's preference for consensus and conflict avoidance has lent itself to extra-regional actors manipulating ASEAN norms to serve their own best interests. ${ }^{18}$ However, this is a restrictive view of ASEAN autonomy that is arguably at odds with the historical record.

For example, with respect to Indonesia's invasion of East Timor in 1975, Leifer argues that US policy towards Southeast Asia was 'an integral, if subordinate, aspect of a wider design in Asia', ${ }^{19}$ focused on 'a strong flexible military presence to help maintain the balance of power'. ${ }^{20}$ Similarly, Jones and Smith believe that ASEAN initiatives during this period merely revealed 'the organization's continuing ambivalence'. ${ }^{21}$ This was because the ASEAN states 'remained ultimately dependent on continued American security commitments'. ${ }^{22}$ These analysts' emphasis on the role of external powers in the region provides little agency for regional states such as Indonesia. However, there is strong evidence to suggest that Indonesia played an active role in securing its own interests at this time. Indeed, Indonesia, as a large regional power and barrier to further communist advances, ${ }^{23}$ was an essential factor in the 'defence of Western interests'. ${ }^{24}$ From this position, Jakarta was able to utilize external power concerns by consistently describing FRETILIN as 'communist-dominated'. ${ }^{25}$ This allowed Indonesia to secure its own security and expansionist interests in the territory. ASEAN solidarity was a vital component in Indonesia's strategy, as evidenced by the Joint Communiqué released following the Ninth ASEAN Ministerial Meeting in Manila on 24-26 June 1976. This evidence suggests greater agency for Indonesia than is currently acknowledged in the realist literature.

According to Leifer, during the Third Indochina War, the position 'adopted by the Association favoured China's interests, above all'. ${ }^{26}$ This was because China represented a 'much more effective means by which to challenge Vietnam's hegemonic position'. ${ }^{27}$ Jones and Smith also minimize ASEAN's role in the resolution of the Third Indochina War, maintaining that the eventual settlement 'represented an archetypal manifestation of great power politics'. ${ }^{28}$ According to this view, 'ASEAN's actual contribution to the Cambodian settlement reveals its role to be both ambiguous and ultimately limited'. ${ }^{29}$ Although Leifer, Jones and Smith offer an accurate portrayal of the role of great powers in Indochina during the Cold War, they take an overly restrictive view of ASEAN autonomy and the role of ASEAN states. 
As shown in Chapter 3, Thailand was a critical factor in China's strategy to oppose Vietnam, with Beijing 'heavily reliant' on Thai cooperation. ${ }^{30}$ A Sino-Thai alliance clearly favoured Thai interests as much as it favoured China's interests. Thailand was now in a position to 'report Vietnamese shellings or attacks on the Thai border and expect that within six hours the Chinese troops on the SinoVietnamese border would repay the Vietnamese in kind'. ${ }^{31}$ Both China and the US viewed a strong ASEAN as a vital component in their anti-Vietnamese strategy. They placed 'major emphasis on the closest consultation with ASEAN countries', ${ }^{32}$ and believed the development of ASEAN's strength to be a positive development. ${ }^{33}$ This clearly provides Thailand, and ASEAN, with a greater role than currently exists in the realist literature.

As stated in Chapter 1, during periods of decreased interest convergence, our analysis shares the same expectations as Leifer and Jones and Smith, and is consistent with existing realist literature. This is evident with respect to the East Timor humanitarian crisis of 1999, which conforms well to realist expectations. According to Leifer, in the period following 1997, ASEAN's troubles moved 'well beyond the competence of the Association to address on any exclusive basis' ${ }^{34}$ Similarly, Jones and Smith argue that 'since 1997, the security situation in East Asia reveals ... that the ASEAN states possess no clear strategy to respond to the challenges the organization currently faces'. ${ }^{35}$ The realist assessment of ASEAN's role in the post-1997 period is persuasive. Evidence provided in this chapter highlights ASEAN's slow response to the crisis, which raises serious questions regarding the Association's ability to respond to regional conflicts. ${ }^{36}$ ASEAN support for Indonesia during this period was not enough to prevent Indonesia's eventual sovereignty violation, and their contribution to the outcome of the East Timor crisis was minimal. ${ }^{37}$ This suggests that external powers play the vital role in the dynamics of ASEAN state resistance to sovereignty violation.

The South China Sea chapter demonstrates 'how more powerful actors can manipulate ASEAN's pliable norms to advance grand strategic interests' ${ }^{38}$ In this view, China has succeeded in dividing the Association, which has pursued a strategy of managing problems rather than solving them'. ${ }^{39}$ This has been compounded by a 'lack of political will' to resolve the dispute. ${ }^{40}$ Realist scholars offer a strong argument. ASEAN regional institutions have been incapable of resolving the South China Sea dispute. These analysts' emphasis on the role of an external actor, the US, is also a necessary one. China's gains in the South China Sea have been predicated on an insufficiently robust US 
response. ${ }^{41}$ However, ASEAN states have greater autonomy than they currently allow for. As this analysis shows, in the post-2013 period, the Philippines and Vietnam actively sought, and partially secured, security commitments from the US. This aspect of regional dynamics requires further theorizing.

Evidence suggests that the existing realist literature on ASEAN offers a strong counter-argument to constructivist theorizing. However, the existing realist perspective in the literature does not offer a strong explanation for ASEAN state autonomy in the historical record. This highlights a gap in the realist literature, which I seek to fill. Indeed, evidence provided here shows that an ASEAN vanguard state has a substantial role in resisting sovereignty violation, when its interest converges with that of an external actor. This approach provides some autonomy to regional states, while maintaining the critical role played by external powers.

\section{Critical theory}

Critical theorist Lee Jones advocates a perspective of regional intervention that can be explained as the outcome of powerful social forces. For Jones, sovereignty and non-interference can be analysed as a technology of power, which is used by domestic groups to help determine the scope of political conflict in a way that best suits their needs. ${ }^{42}$ Evidence provided in this analysis suggests that Jones actually overemphasizes the impact business groups and social forces have on the state, and fails to advance a non-statist argument that effectively surpasses alternative theorizing. This is evident with respect to the Indonesian invasion of East Timor in 1975. Jones argues that 'Indonesia's invasion and ASEAN's support is best explained by the fear that a leftist state would emerge after Timor's decolonization, providing a possible base for communist "subversion". ${ }^{43}$ In this view, Indonesia's fears 'were conditioned by the conflicts that had given rise to the Suharto regime, the social order it was attempting to defend, and the likely effects of Timorese independence on that order' ${ }^{44}$

However, analysis in Chapter 2 has shown that this assessment fails to consider an abundance of evidence suggesting that Indonesia was well aware that there was little communist influence in East Timor. ${ }^{45}$ That Suharto still wished to annex the territory suggests the existence of ulterior motives, with territorial gain the most convincing. Arguably, in trying to emphasize the role of Indonesia's domestic forces, Jones goes too far in downplaying the role of external powers. External actors 
played a vital role prior to the invasion, when Ford gave Suharto's East Timor policy his 'understanding' in a meeting in December 1975, ${ }^{46}$ and following the invasion, when external powers prevented the UN from providing an effective response to the crisis. ${ }^{47}$ These external powers sought to secure their own interests in regional affairs, a fact consistent with realist expectations.

With regard to the Third Indochina War, Jones argues that ASEAN responded to Vietnam's invasion of Cambodia 'not to defend its noninterference principle, but rather to contain revolution in Indochina'. ${ }^{48}$ The Vietnamese threat is 'not understood in conventional, military, balance-of-power terms', but in terms of 'the likely consequences of the invasion for the balance of forces within their own societies'. ${ }^{49}$ However, evidence shows that Jones has focused a disproportionate amount of his narrative on ASEAN's opposition to the spread of revolution for domestic political reasons. This approach fails to consider a variety of other far more critical factors. First, ASEAN's position in the Cold War regional environment was a clear source of insecurity, with ASEAN unable to influence its wider regional environment'.${ }^{50}$ This had a major impact on regional state actions and behaviour, with ASEAN states concerned that US retrenchment would leave a regional power vacuum, which other great powers may attempt to fill.

Second, the ASEAN states had clear external security concerns, which Jones minimizes. While security fears varied amongst the ASEAN member states, Vietnam's treaty of friendship with the Soviet Union, and subsequent invasion of Cambodia, elicited great concern. This demonstrated that Vietnam, aided by the Soviet Union, was prepared to violate state sovereignty in pursuit of its interests. Third, Vietnam's invasion provided the ASEAN states with external reasons for collaboration with the great powers. As Leifer notes, 'an informal alignment between Thailand, Kampuchea and China was forged by the end of 1975, based on a common interest in containing the extension of Vietnamese influence' ${ }^{51}$ All of these critical factors conform to realist expectations of state behaviour during periods of insecurity and conflict. By underemphasizing these factors in favour of domestic variables, Jones fails to provide a portrayal of the conflict that encompasses all of the relevant facts.

Jones argues that ASEAN's response to the 1999 East Timor humanitarian crisis was 'principally due to their fear of contagion from the social and economic unrest spreading from Indonesia'. ${ }^{52}$ At this time, ASEAN states 'actively encouraged and participated in a humanitarian intervention in East Timor', becoming 'increasingly 
involved in Indonesia's "internal" affairs' ${ }^{53}$ Indeed, there is evidence to suggest that Jones has overemphasized the role of ASEAN in the crisis. As shown in Chapter 4, ASEAN feared that the East Timor crisis would elicit Western interference in the internal affairs of ASEAN states, 'using the norm of humanitarian intervention as justification' ${ }^{54}$ Canberra wanted to scale back its involvement in INTERFET, but this could not be implemented because ASEAN countries were not prepared for deployment and were unwilling to cover the costs of a lengthy involvement. ${ }^{55}$

By overemphasizing the role of domestic factors during the crisis, Jones is also unable to adequately address why external powers changed their East Timor policy following the Asian Financial Crisis of 1997. Suharto's resistance to accepting an IMF economic aid and reform package was disconcerting for the US, which wanted a stable and prosperous Indonesia in Southeast Asia. Washington pushed for reform in Indonesia, to 'foster a broader economic recovery in Asia', ${ }^{56}$ and protect 'vital sea-lanes through which 40 percent of the world's shipping passes'. ${ }^{57}$ Similarly, Australia feared that Suharto's refusal to accept reforms could cause regional instability 'and precipitate a complete economic catastrophe'. ${ }^{58}$ Australia's priorities were therefore to 'support Indonesia's democratic transformation, and to sustain a good relationship with TNI'. ${ }^{59}$ These external powers played a critical role in forcing Indonesia to change its East Timor policy. This is indicative of the impact great powers can have on regional state autonomy when in pursuit of their own interests. This is seriously underemphasized in Jones' analysis in favour of domestic factors and the internal role of ASEAN states.

That Jones fails to provide a non-statist account of the South China Sea dispute leads us to question whether his theory can adequately account for the empirical record of Sino-ASEAN maritime interactions. This is particularly in light of the fact that the dispute involves key external powers, most notably China and the US, the interaction of which is integral to any analysis of the conflict. Critically, it is not clear what impact, if any, ASEAN domestic groups have had on the conflict. This raises questions about the relevance of the critical theory approach to an analysis of this central issue in ASEAN's postCold War international relations, and provides space for an alternative account of sovereignty and intervention in Southeast Asia. 


\section{Vanguard state theory}

The foregoing analysis has shown how constructivist and critical theory approaches provide an incomplete picture of Southeast Asian sovereignty violation. Realist responses are more compelling. However, their overemphasis on ASEAN's lack of autonomy is not totally persuasive. This book has sought to build on these approaches and contribute to the realist argument, by proposing vanguard state theory. According to this theory, ASEAN's sovereignty record is in fact highly dependent on the stance of external actors, whose interests align with the organisation's. The theory focuses on the role of an ASEAN vanguard state, which seeks to set the agenda of ASEAN and garner great power security commitments in order to realize its own state interests.

For the purposes of the analysis, the book began with the assumption that state interests are premised on the basic point of seeking survival. Building on the works of Timothy Crawford ${ }^{60}$ and Daryl Press, ${ }^{61}$ vital state interests were defined as involving 'self-preservation, political independence, and, by extension, defence of strategically vital areas'. ${ }^{62}$ Interest convergence was measured by identifying symmetric or asymmetric interests, ${ }^{63}$ and arrangements for cooperation between states. This was conceptualized as a dynamic process, where small states 'actively seek maximum great-power commitment to their security interests' ${ }^{64}$ The central argument is that when a clear and substantial interest convergence occurs between an ASEAN state and an external power, an ASEAN vanguard state plays the important and necessary function of actively seeking and supporting a great power commitment to regional policies, which is consistent with the interests of both the ASEAN state and the external actor. An ASEAN state can therefore have an active role in resisting sovereignty violation. Without this interest convergence, ASEAN is unable to successfully resist violations to its sovereignty.

Four case studies were selected to test this argument. The findings, summarized here, provide a strong case for the utility of vanguard state theory. Indonesia's invasion of East Timor in 1975 is an example of ASEAN vanguard state success in resisting sovereignty violation. The analysis has shown how the uncertain regional environment of 1975, when 'dramatic communist victories in Indochina were a matter for considerable concern', acted as a catalyst for interest convergence between Indonesia, the US and Australia regarding Indonesia's East Timor policy. ${ }^{65}$ East Timor's proximate location to Indonesia's border, and the vacuum that it represented, constituted 
a threat to Indonesia at a particularly uncertain period in the Cold War. Indonesian interests were also offensive in nature. Jakarta sought to maximize power regionally through expansion. Indonesia actively sought US and Australian approval for the invasion of East Timor and the integration of the territory into the archipelago. For these external powers, Indonesia was a vital component in their own Cold War foreign policies. Indonesia therefore played the important and necessary function of actively seeking and supporting a great power commitment to regional policies, which were consistent with the interests of both Indonesia and the US and Australia. In doing so, Indonesia was able to resist any potential violation to its sovereignty from the international community in the wake of the East Timor invasion.

The Third Indochina War (1978-1991) is also an example of ASEAN vanguard state success in resisting sovereignty violation. The analysis showed how, following Vietnam's invasion of Cambodia in 1978, an informal alliance developed between Thailand, China, the ASEAN states, the ousted Khmer Rouge, and to a lesser extent the US, in an effort to contain Vietnamese and Soviet influence in Southeast Asia. ${ }^{66}$ As a consequence of high interest convergence between Thailand and a designated external power, China, ASEAN was able to resist violations to the sovereignty of Thailand from a Soviet-backed Vietnam. An expansionist and aggressive Vietnam, backed by the Soviet Union, posed a clear threat to the external powers and to the ASEAN states. They responded to this threat by engaging in external and internal balancing strategies, to secure the vital state interest of autonomy.

During the East Timor humanitarian crisis of 1999, substantial interest divergence between Indonesia and the US and Australia caused Indonesia's failure to resist sovereignty violation by actors external to the region. The 1997 Asian Financial Crisis acted as a catalyst for external power interest change. It was in the interests of Australia and the US to have a strong and stable Indonesia in the region. Economic instability, and resulting domestic instability, threatened joint ventures and regional security. Suharto's refusal to accept reform packages was indicative of an asymmetry of interests between Indonesia and these external powers. ${ }^{67}$ INTERFET's subsequent intervention in East Timor comprised a violation of Indonesian sovereignty. Significantly, the available evidence strongly suggests that intervention would not have occurred in the absence of external power interest change. Crucially, support within ASEAN for Indonesia's East Timor policy was not enough to prevent Indonesia's eventual sovereignty violation. This raises questions about ASEAN and its ability to maintain regional 
autonomy under challenge from sufficiently powerful external actors. Indeed, this case provides substantial evidence for our general argument that intervention by external powers has been instrumental for the outcome of the majority of Southeast Asia's regional problems.

The South China Sea Dispute (1992-present) is an example of partial interest convergence between the ASEAN vanguard states of the Philippines and Vietnam, and the US. Despite these ASEAN states having crucial interests at stake with respect to their sovereignty in the South China Sea, they have been unable to generate a robust security commitment from the US, which has largely pursued interests outside of the region. This lack of credible backing has contributed to a divided ASEAN, which has been unable to provide an effective solution to the problem. Despite evidence of increasing interest convergence between 2012 and 2016, this did not reach the levels required to prevent ASEAN vanguard state sovereignty violation. As stated in Chapter 5, without this, these states will continue to cede sovereignty to China in the maritime region.

\section{Dynamics of state interaction}

What does the analysis presented tell us about ASEAN state and external power behavioural strategies during different periods in history? And what are the implications of these findings for states outside of the Southeast Asian region? As the four cases under analysis show, there are some key strategic commonalities in vanguard state behaviour during periods of regional intervention. Both Indonesia and Thailand, in their role as vanguard state, utilized elite diplomatic meetings or exchanges to impress on external powers the need for their understanding and economic assistance in the Cold War period. Notably, these states were adept at utilizing external power geopolitical fears to their own advantage. This is in addition to having an astute awareness of their own position in the regional environment, and how their alignment could shift the regional balance of power. Similar strategic behaviour is evident towards ASEAN, with the vanguard state using diplomatic meetings, in addition to the local media, to express their interests.

There is however one notable difference in vanguard state strategy at the regional level that we do not see at the international level. This is the use of coercive tactics, which both Indonesia and to a lesser extent Thailand engaged in to force other ASEAN states to comply with their interests. Such coercive strategies include boycotting member 
state initiatives within ASEAN, such as refusal to adopt economic proposals, excluding member states from security and intelligence briefings, and denouncing member states in news reports and the media. Significantly, these strategies reflect ASEAN power dynamics, with Indonesia able to utilize such strategies most effectively, and with states such as the Philippines and Vietnam least able to coerce member states to comply with their interests.

We are also able to see a number of key strategic commonalities in the behaviour of external powers towards the vanguard state. These generally include large sums of economic assistance, the transfer of arms to enhance vanguard state capabilities, and the implementation of a variety of comprehensive partnerships, joint vision statements and joint treaties. There is also evidence of external powers seeking to persuade other powers to enhance their vanguard state support. For example, during the Third Indochina War, China consistently sought to persuade the US to enhance support to Thailand to prevent it from falling victim to Vietnamese expansion. Similarly, following Indonesia's invasion of East Timor, the Australian Prime Minister travelled to the US to appeal to President Clinton to withdraw human rights considerations from the drafting of defence contracts. These initiatives come at fairly little cost to the external power, and yet they have a significant impact on an ASEAN vanguard state's ability to pursue its interests.

As the four case studies show, a vanguard state is best able to secure a convergence of interests when there exists a common threat consensus, both regionally and internationally. At such times, ASEAN can be conceptualized as a unitary actor. Due to the disparate interests of states however, such interest convergence is rare. In reality, we can conceptualize ASEAN as a grouping of regional states, where each member seeks to secure its own interests in an uncertain geopolitical environment. This is particularly notable in the post-Cold War period. Indeed, it is no coincidence that in the last two cases under analysis, ASEAN vanguard state-external power interest convergence has been under threat. The reasons for this are varied, although three in particular stand out. First, there is a lack of common threat consensus in the period since the end of the Cold War. The unifying Soviet threat has dissipated, leaving behind a myriad of threats that impact regional states and external powers differently. Related to this, we see a general lack of faith in US engagement in Southeast Asia since the end of the Cold War. The US has been distracted by its own protracted conflicts in the Middle East. This has left the ASEAN states unsure of whether they can rely on the US during periods of crisis 
or intervention. Finally, ASEAN enlargement during this period, to include the states of Vietnam, Laos, Myanmar and Cambodia, has seriously impacted on the Association's ability to act with any degree of consensus. As the South China Sea case has shown, states such as Cambodia have their own interests to pursue, something which external powers such as China can utilize to their own advantage.

Changes in the international environment since the end of the Cold War have necessitated changes in ASEAN vanguard state strategic behaviour. This includes searching for other regional and international allies that can support ASEAN vanguard state interests, as evidenced by Vietnam's enhanced diplomatic relations with states such as India and Japan. This is in addition to an increase in internal balancing through the enhancement of state material capabilities. These steps are undoubtedly necessary but, as the Vietnam case shows, difficult to translate into successful resistance to sovereignty violation in the absence of great power backing. Clearly, these findings have utility beyond the Southeast Asian region. The strategies presented here show the ways in which small states can utilize regional organization membership in an attempt to secure their own interests and uphold their autonomy in an uncertain regional environment.

\section{ASEAN, intervention and the responsibility to protect}

What is the future of ASEAN sovereignty? Will a strict adherence to traditional Westphalian sovereignty continue to be the overriding concern for regional states in the post-Cold War era? Some commentators suggest not. In the past two decades, there has been a growing concern for the rights of the individual, and the duty of a state to protect its citizens. The doctrine of humanitarian intervention and its corollary, the Responsibility to Protect, has subsequently received increased interest from certain areas of the international community. This section will examine this shift towards humanitarian principles. It will consider to what extent the principle of humanitarian intervention has been adopted by the ASEAN states, and whether this might herald the end of the traditional Westphalian sovereignty model. 


\section{Humanitarian intervention and the responsibility to protect}

Humanitarian intervention can be defined as 'the threat or use of force across state borders by a state (or group of states) aimed at preventing or ending widespread and grave violations of the fundamental human rights of individuals other than its own citizens, without the permission of the state within whose territory force is applied'. ${ }^{68}$ Exception to the general rule of non-intervention conflicts with the principle of state sovereignty, which is based upon territoriality and the exclusion of external actors from domestic authority structures. ${ }^{69}$

Inherent in the principle of humanitarian intervention is the belief that 'states that violate human rights do not deserve sovereign immunity from outside interference in their internal affairs' ${ }^{70}$ The concept is not a new one. John Stuart Mill made the case in 1859 that intervention should be permitted to prevent recurring aggressive wars and to end protracted civil wars. ${ }^{71}$ The UN General Assembly unanimously agreed in September 2005 that 'each individual state has the responsibility to protect its populations from genocide, war crimes, ethnic cleansing and crimes against humanity'. ${ }^{72}$ The UNGA encouraged the international community to 'help states exercise this responsibility', and to take 'collective action, in a timely and decisive manner' when there is evidence that a state has manifestly failed in its responsibility to protect. $^{73}$

\section{ASEAN's response to humanitarian intervention and $R 2 P$}

$\mathrm{R} 2 \mathrm{P}$ is the current incarnation of the case for humanitarian intervention. ${ }^{74}$ It signifies a focal shift from the state as the primary actor to the human rights of the individual. The advent of R2P has sparked scholarly debate regarding ASEAN's reception of the norm, and its conflict with the existing regional norm of non-interference. See Seng Tan argues that ASEAN is 'gradually embracing an ethic of sovereignty qua responsibility', ${ }^{75}$ and is specifically embracing 'the logic of responsibility as provision' ${ }^{76}$ However, Tan also notes that the ASEAN states 'continue to maintain and promote sovereignty as an inalienable and unequivocal right rather than as a responsibility'. ${ }^{77}$ It is therefore unclear 'whether responsibility to provide constitutes a stepping stone to R2P in Southeast Asia'. ${ }^{78}$

According to Acharya, through a process of constitutive localisation, local actors are reconstructing foreign ideas and norms to merge with local conditions. ${ }^{79}$ This is an idea mirrored by Bellamy and 
Drummond, who argue that 'many Southeast Asian states are moving away from the traditional notion of sovereignty and towards accepting a localized variant of sovereignty as responsibility'. ${ }^{80}$ Capie disputes this assessment however, arguing that 'neither ASEAN nor the ASEAN Regional Forum has institutionalized R2P in any form'. ${ }^{81}$ For Capie, localization has failed to take place due to an insufficient number of insider actors that are receptive to the norm. It is therefore concluded that many states still view R2P 'as a potential threat to sovereignty and regime security'. ${ }^{82}$

In a July 2000 speech, Rodolfo C Severino, Secretary General of ASEAN, stated that 'national sovereignty and its handmaiden, the principle of non-interference, are the only conceptual bulwarks protecting the small and the weak from domination by the powerful. In the absence of a supranational government, it is indispensable to any sort of international order' ${ }^{83}$ With regard to humanitarian intervention, Severino asked: 'Who decides? There is a tendency for powerful states or groups of them to represent themselves as the "international community". ${ }^{84}$ Governments are therefore able to 'use humanitarian impulses as a cover for intervention that is actually undertaken for national policy objectives' ${ }^{85}$ Severino summarizes his, and by extension, ASEAN's view of intervention, by stating that, 'except in extreme cases in which the international community may have to be mobilized through the United Nations, the welfare of people, particularly in Southeast Asia today, is better served through economic interaction and integration, through the opening of societies to one another, than through blatant intervention and ostentatious gestures, which seldom work anyway' ${ }^{86}$ This highlights an overriding ASEAN state concern with the inviolable sovereignty of the state.

\section{In summary}

For ASEAN, the appeal of Westphalian sovereignty lies in its two fundamental principles: territoriality and the exclusion of external actors from domestic authority structures. ${ }^{87}$ The TAC seeks to enshrine these principles, with the aim of protecting the autonomy of the state. As a collection of weak states, ASEAN is vulnerable to intervention, which can represent a 'thinly veiled quest for renewed Western imperialism', ${ }^{88}$ or even 'Eastern' imperialism, in the case of China in the 21st century. As Prime Minister Mahathir of Malaysia stated, following the advent of peacekeeping forces in East Timor, the implication was that in times of humanitarian crisis, the use of military 
force against a sovereign state could be determined and sanctioned by a concert of Western states. ${ }^{89}$ The legitimisation of intervention could increase great power interference into state affairs, destabilising regime security and undermining state autonomy. Despite Indonesia, Malaysia, Myanmar, the Philippines, Singapore and Vietnam all agreeing to 'the main fundamentals about the R2P' ${ }^{90}$ the Southeast Asian states have stressed that 'the principle should be understood as an ally of sovereignty ... inferring that it does not - and should not - contravene the principle of non-interference'. ${ }^{91}$ Ultimately, for the Southeast Asian states, the costs of intervention are likely to outweigh the humanitarian benefits.

What, therefore, is the future of ASEAN sovereignty? Analysis presented in this chapter suggests that ASEAN's future sovereignty is unlikely to differ substantially from the Association's past. Despite what appeared to be a turn in the post-Cold War period towards humanitarian intervention and a responsibility to protect, in reality, regional states are reluctant to move beyond the traditional Westphalian model of sovereignty. The principle of non-intervention is as important to the states of ASEAN today as it was during the Cold War. This suggests a case for bringing the sovereign state back into the study of regionalism in Southeast Asia. This argument conflicts with the vast majority of ASEAN theorists, who continue to argue a case for regional, rather than state autonomy, despite evidence pointing to the contrary. Vanguard state theory is able to remedy this deficit in the literature, to provide a definitive explanation for the mixed record of resistance to sovereignty violation in Southeast Asia.

\section{Notes}

1 Acharya, Constructing a Security Community, 80.

2 Acharya, Constructing a Security Community, 3.

3 Acharya, The Making of Southeast Asia, 3.

4 Acharya, The Making of Southeast Asia, 1.

5 Haacke, ASEAN'S Diplomatic and Security Culture, 40.

6 Haacke, ASEAN'S Diplomatic and Security Culture, 7.

$7 \mathrm{Ba},[$ Re]Negotiating East and Southeast Asia, 29.

8 Acharya, Constructing a Security Community, 79; Ba, [Re]Negotiating East and Southeast Asia, 85; Haacke, ASEAN's Diplomatic and Security Culture, 111.

$9 \mathrm{Ba},[$ Re]Negotiating East and Southeast Asia, 87.

10 Acharya, Constructing a Security Community, 92.

11 Acharya, Constructing a Security Community, 80.

12 Acharya, Constructing a Security Community, 152. 
$13 \mathrm{Ba}$, Re]Negotiating East and Southeast Asia, 176-177; Acharya, Constructing a Security Community in Southeast Asia, 211.

14 M Taylor Fravel, "China's Strategy in the South China Sea", Contemporary Southeast Asia 33, no. 3 (2011), 292-319.

15 Tan, Security Strategies in the Asia-Pacific, 149.

16 Chin and Suryadinata, Michael Leifer: Selected Works, 151. Reprinted from Leifer, "Regional Solutions to Regional Problems?"

17 Chin and Suryadinata, Michael Leifer: Selected Works, 151. Reprinted from Leifer, "Regional Solutions to Regional Problems?"

18 Jones and Smith, "Making Process, Not Progress", 150.

19 Chin and Suryadinata, Michael Leifer: Selected Works, 222. Reprinted from Leifer, Conflict and Regional Order in Southeast Asia.

20 Chin and Suryadinata, Michael Leifer: Selected Works, 223. Reprinted from Leifer, Conflict and Regional Order in Southeast Asia.

21 Jones and Smith, ASEAN and East Asian International Relations, 51.

22 Jones and Smith, ASEAN and East Asian International Relations, 52.

23 Hansen, "Indonesia 1975: National Resilience and Continuity", 146.

24 Barbedo de Magalhães, East Timor Indonesian Occupation and Genocide, 14.

25 Hanhimäki, The Flawed Architect, 478.

26 Leifer, ASEAN and the Security of South-East Asia, 98.

27 Leifer, ASEAN and the Security of South-East Asia, 97.

28 Jones and Smith, ASEAN and East Asian International Relations, 55.

29 Jones and Smith, ASEAN and East Asian International Relations, 54.

30 US Department of State, Foreign Relations of the United States, Vol. XIII, 275.

31 Chambers, "The Chinese and the Thai are Brothers", 616.

32 US Department of State, Foreign Relations of the United States, Vol. XIII, 265.

33 US Department of State, Foreign Relations of the United States, Vol. XIII, 313.

34 Chin and Suryadinata, Michael Leifer: Selected Works, 132. Reprinted from Leifer, "The ASEAN Peace Process".

35 Jones and Smith, ASEAN and East Asian International Relations, 71.

36 Dupont, "ASEAN's Response to the East Timor Crisis", 167.

37 Cotton, East Timor, Australia and Regional Order, 84.

38 Jones, Khoo and Smith, Asian Security and the Rise of China, 113.

39 Jones, Khoo and Smith, Asian Security and the Rise of China, 111.

40 Leifer, "Stalemate in the South China Sea", 7-8.

41 Jones and Smith, "Constructing Communities", 179.

42 Jones, ASEAN, Sovereignty and Intervention in Southeast Asia, 8.

43 Jones, ASEAN, Sovereignty and Intervention in Southeast Asia, 59.

44 Jones, ASEAN, Sovereignty and Intervention in Southeast Asia, 59. 
Australia Department of Foreign Affairs and Trade, Documents on Australian Foreign Policy, 58.

46 US Department of State, Foreign Relations of the United States, Vol. E-12, 141.

47 Scheiner, "The United States: From Complicity to Ambiguity", 119.

48 Jones, ASEAN, Sovereignty and Intervention in Southeast Asia, 76.

49 Jones, ASEAN, Sovereignty and Intervention in Southeast Asia, 78.

50 Leifer, ASEAN and the Security of South-East Asia, 76.

51 Leifer, ASEAN and the Security of South-East Asia, 97.

52 Jones, ASEAN, Sovereignty and Intervention in Southeast Asia, 151-2.

53 Jones, ASEAN, Sovereignty and Intervention in Southeast Asia, 157, 159.

54 Dupont, "ASEAN's Response to the East Timor Crisis", 164.

55 Haq, "Mahathir calls for reduced Australian presence in Timor".

56 Dori, "Indonesia's Economic and Political Crisis", 1998.

57 Dori, "Indonesia's Economic and Political Crisis", 1998.

58 Ambrosio, "East Timor Independence", 129.

59 White, “The Road to INTERFET", 71.

60 Crawford, Pivotal Deterrence, 30-31.

61 Press, Calculating Credibility, 25-28.

62 Crawford, Pivotal Deterrence, 31.

63 Ross, "Navigating the Taiwan Strait", 48-85.

64 Ciorciari, The Limits of Alignment, 2.

65 Leifer, "Indonesia and the Incorporation of East Timor", 349.

66 Khoo, Collateral Damage, 131.

67 Ross, "Navigating the Taiwan Strait", 48-85.

68 JL Holzgrefe, "The humanitarian intervention debate", in Humanitarian Intervention. Ethical, Legal and Political Dilemmas, ed. JL Holzgrefe and Robert O Keohane (Cambridge: Cambridge University Press, 2003), 18.

69 Krasner, Sovereignty: Organized Hypocrisy, 20.

70 Robert A Pape, "When Duty Calls: A Pragmatic Standard of Humanitarian Intervention”, International Security 37, no. 1 (Summer 2012), 45.

71 John Stuart Mill, "A Few Words on Non-Intervention”, in Essays on Politics and Culture, ed. Gertrude Himmelfarb (Gloucester: Peter Smith, 1973), 368-384.

72 United Nations General Assembly, "2005 World Summit Outcome”, Resolution A/60/L.1, 24 October 2005, paragraphs 138-139.

73 UNGA, "2005 World Summit Outcome”, paragraphs 138-139.

74 Michael W Doyle, "International Ethics and the Responsibility to Protect”, International Studies Review 13 (2011), 73.

75 See Seng Tan, "Providers not Protectors: Institutionalising Responsible Sovereignty in Southeast Asia”, Asian Security 7, no. 3 (2011), 202.

76 Tan, "Providers not Protectors", 213. 
77 Tan, "Providers not Protectors", 202.

78 Tan, "Providers not Protectors", 214.

79 Acharya, Whose Ideas Matter? 15.

80 Alex J Bellamy and Catherine Drummond, "The Responsibility to Protect in Southeast Asia: Between Non-interference and Sovereignty as Responsibility”, The Pacific Review 24, no. 2 (2011), 196.

81 David Capie, "The Responsibility to Protect Norm in Southeast Asia: Framing, Resistance and the Localisation Myth", The Pacific Review 25, no. 1 (March 2012), 89.

82 Capie, "The Responsibility to Protect Norm in Southeast Asia", 76.

83 Rodolfo C Severino, "Sovereignty, Intervention and the ASEAN Way", Address given at the ASEAN Scholars' Roundtable organized by the Konrad Adenauer Foundation and the Singapore Institute of International Affairs, Singapore, 3 July 2000, http://www.asean.org/ resources/2012-02-10-08-47-56/speeches-statements-of-the-formersecretaries-general-of-asean/item/sovereignty-intervention-and-theasean-way-3-july-2000.

84 Severino, "Sovereignty, Intervention and the ASEAN Way".

85 Severino, "Sovereignty, Intervention and the ASEAN Way".

86 Severino, "Sovereignty, Intervention and the ASEAN Way".

87 Krasner, Sovereignty: Organized Hypocrisy, 20.

88 Krasner, Sovereignty: Organized Hypocrisy, 20.

89 Dupont, "ASEAN's Response to the East Timor Crisis", 165.

90 Bellamy and Drummond, "The Responsibility to Protect in Southeast Asia", 194.

91 Bellamy and Drummond, "The Responsibility to Protect in Southeast Asia”, 194. 



\section{References}

Acharya, Amitav. Constructing a Security Community in Southeast Asia: ASEAN and the Problem of Regional Order. 3rd ed., Hoboken,NJ: Taylor \& Francis, 2014.

Acharya, Amitav. The Making of Southeast Asia. New York: Cornell University Press, 2012.

Acharya, Amitav. Whose Ideas Matter? Agency and Power in Southeast Asia. New York: Cornell University Press, 2009.

Agnote, Dario. "Manila Expresses Concern Over Turmoil in Indonesia". Kyodo News, 5 May 1999.

"Agreement between the Government of the Commonwealth of Australia and the Government of the Republic of Indonesia establishing Certain Seabed Boundaries". Signed in Canberra on 18 May 1971.

Al Jazeera. "Rodrigo Duterte: 'I don't care about human rights". 08 August 2016, http://www.aljazeera.com/news/2016/08/rodrigoduterte-human-rights-160806211448623.html.

Alatas, Ali. The Pebble in the Shoe: The Diplomatic Struggle for East Timor. Jakarta: Aksara Karunia, 2006.

Ambrosio, Thomas. "East Timor Independence: The Changing Nature of International Pressure". In Transforming East Asian Domestic and International Politics, edited by Robert Compton Jr, 115-137. Aldershot: Ashgate, 2002.

Andolong, Ina. "Cayetano: China did not bully PH with threat". CNN, 23 May 2017, http://cnnphilippines.com/news/2017/05/22/ cayetano-china-did-not-bully-PH.html.

Aneja, Urvashi. "Interanational NGOs and the Implementation of the Norm for Need-Based Humanitarian Assistance in Sri Lanka”. In Implementation \& World Politics, edited by Alexander Betts and Phil Orchard, 85-104. Oxford: Oxford University Press, 2014.

Ang, Cheng Guan. Singapore, ASEAN and the Cambodia Conflict 19781991. Singapore: NUS Press, 2013.

Ang, Cheng Guan. "The South China Sea Dispute Revisited". Australian Journal of International Affairs 54, no. 2, 2000: 201-215. 
Ap, Tiffany, Jennifer Rizzo and Kevin Liptak. "Obama lifts US arms ban on Vietnam”. CNN Politics, 24 May 2016, http://edition.cnn. com/2016/05/23/politics/obama-vietnam-trip/index.html.

Asia Times Online. "Howard Doctrine provokes Malaysian Rage". 25 September 1999.

Association of Southeast Asian Nations. "Turning Vision Into Reality For a Dynamic ASEAN Community”. Chairman's Statement of the 28th and 29th ASEAN Summits, Vientiane, 6-7 September 2016, http://asean.org/storage/2016/08/Final-Chairmans-Statement-ofthe-28th-and-29th-ASEAN-Summits-rev-fin.pdf.

Association of Southeast Asian Nations. "Joint Statement of the Foreign Ministers of ASEAN Member States and China on the Full and Effective Implementation of the Declaration of the Conduct of Parties in the South China Sea”. July 2016, http://asean.org/ storage/2016/07/Joint-Statement-on-the-full-and-effectiveimplementation-of-the-DOC-FINAL.pdf.

Association of Southeast Asian Nations. "2002 Declaration on the Conduct of Parties in the South China Sea". Phnom Penh, 4 November 2002, http://www.assidmer.net/doc/Documents-onASEAN-and-South-China-Sea-as-of-June-2011.pdf.

Association of Southeast Asian Nations. "Joint Communique of the 33rd ASEAN Ministerial Meeting”. Bangkok, 24-25 July 2000.

Association of Southeast Asian Nations. "1999 Joint Communiqué of the 32nd ASEAN Ministerial Meeting”. Singapore, 23-24 July 1999 , http://www.assidmer.net/doc/Documents-on-ASEAN-and-SouthChina-Sea-as-of-June-2011.pdf.

Association of Southeast Asian Nations. "1992 ASEAN Declaration on the South China Sea". Adopted by the Foreign Ministers at the 25th ASEAN Ministerial Meeting, Manila, 22 July 1992, http:// www.assidmer.net/doc/Documents-on-ASEAN-and-South-ChinaSea-as-of-June-2011.pdf.

Association of Southeast Asian Nations. "Joint Press Statement The Special ASEAN Foreign Ministers Meeting on Indochinese Refugees". Bangkok, 13 January 1979.

Association of Southeast Nations. "Joint Communique of the Ninth ASEAN Ministerial Meeting”. Manila, 24-26 June 1976.

Association of Southeast Asian Nations. Treaty of Amity and Cooperation in Southeast Asia, Indonesia, 24 February 1976. Chapter One, Article 2, http://www.asean.org/news/item/treaty-of-amityand-cooperation-in-southeast-asia-indonesia-24-february-1976-3. 
Association of Southeast Asian Nations. The ASEAN Declaration (Bangkok Declaration) Bangkok, 8 August 1967, http://asean. org/the-asean-declaration-bangkok-declaration-bangkok-8august-1967/.

Aubrey, Jim. "Canberra: Jakarta's Trojan Horse in East Timor". In The East Timor Question: The Struggle for Independence from Indonesia, edited by Paul Hainsworth and Stephen McCloskey, 133-150. London: Tauris, 2000.

Australia Department of Foreign Affairs and Trade. Documents on Australian Foreign Policy: Australia and the Indonesian Incorporation of Portuguese Timor, 1974-1976, edited by Wendy Way. Victoria: Melbourne University Press, 2000.

$\mathrm{Ba}$, Alice. "Institutional divergence and convergence in the AsiaPacific? ASEAN in practice and theory". Cambridge Review of International Affairs 27, no. 2, 2014: 295-318.

$\mathrm{Ba}$, Alice. [Re]Negotiating East and Southeast Asia: Region, Regionalism and the Association of Southeast Asian Nations. Stanford: Stanford University Press, 2009.

Baliga, Ananth, and Vong Sokhend. "Cambodia again blocks ASEAN statement on South China Sea”. The Phnom Penh Post, 25 July 2016, http://www.phnompenhpost.com/national/cambodia-again-blocksasean-statement-south-china-sea.

Ball, Desmond. "Silent Witness: Australian Intelligence and East Timor". The Pacific Review 14, no. 1, 2001: 35-62.

Bangkok Post. "Govt threatens to arrest errant rights activists". 20 July 1994.

Bangkok Post. "Prasong firm on East Timor Policy". 19 July 1994.

Bangkok Post. "Govt tightens curbs on NGO activities". 16 July 1994. Barbedo de Magalhães, António P. East Timor Indonesian Occupation and Genocide. Porto: Oporto University, 1992.

Bartrop, Paul R., and Steven Leonard Jacobs, eds. Modern Genocide: The Definitive Resource and Document Collection. Santa Barbara, CA: ABC-CLIO, 2015.

Baviera, Aileen SP. "An ASEAN Perspective on the South China Sea" China-ASEAN Collision or China-US Hegemonic Competition?" In Entering Unchartered Waters? ASEAN and the South China Sea, edited by Pavin Chachavalpongpun, 88-115. Singapore: Institute of Southeast Asian Studies, 2014.

Beckman, Robert C. "ASEAN and the South China Sea Dispute". In Entering Unchartered Waters? ASEAN and the South China Sea, edited by Pavin Chachavalpongpun, 15-36. Singapore: Institute of Southeast Asian Studies, 2014. 
Beeson, Mark. "Can ASEAN Cope with China?" Journal of Current Southeast Asian Affairs 35, no. 1, 2016: 5-28.

Bellamy, Alex J, and Catherine Drummond. "The Responsibility to Protect in Southeast Asia: Between Non-interference and Sovereignty as Responsibility”. The Pacific Review 24, no. 2, 2011: 179-200.

Betts, Alexander. "From Persecution to Deprivation: How Refugee Norms Adapt at Implementation". In Implementation \& World Politics, edited by Alexander Betts and Phil Orchard, 29-49. Oxford: Oxford University Press, 2014.

Betts, Alexander, and Phil Orchard. "Introduction: The Normative Institutionalization-Implementation Gap”. In Implementation \& World Politics, edited by Alexander Betts and Phil Orchard, 1-28. Oxford: Oxford University Press, 2014.

Betts, Alexander, and Phil Orchard. "Conclusions: Norms and the Politics of Implementation”. In Implementation \& World Politics, edited by Alexander Betts and Phil Orchard, 269-28. Oxford: Oxford University Press, 2014.

Bodeen, Christopher. "Recent developments surrounding the South China Sea dispute". Philstar, 23 August 2017, http://www.philstar. com/headlines/2016/08/23/1616443/recent-developmentssurrounding-south-china-sea-dispute.

Budiardjo, Carmel. "The Legacy of the Suharto Dictatorship". In The East Timor Question: The Struggle for Independence from Indonesia, edited by Paul Hainsworth and Stephen McCloskey, 51-68. London: Tauris, 2000.

Bower, Ernest, and Derwin Pereira. "Convince ASEAN countries that US pivot to Asia is no empty promise”. Straits Times, 21 April 2014, http://www.straitstimes.com/opinion/convince-asean-countriesthat-us-pivot-to-asia-is-no-empty-promise.

Burchill, Scott. "East Timor, Australia and Indonesia". In Guns and Ballot Boxes: East Timor's Vote for Independence, edited by Damien Kingsbury, 169-184. Victoria: Monash Asia Institute, 2000.

Bush, Richard C. "The Response of China's Neighbours to the US "Pivot" to Asia". Brookings, 31 January 2012, https://www.brookings. edu/on-the-record/the-response-of-chinas-neighbors-to-the-u-spivot-to-asia/.

Buszynski, Leszek. "Southeast Asia in the Post-Cold War Era: Regionalism and Security". Asian Survey 32, no. 9. 1992: 830-847. Buszynski, Leszek. Soviet Foreign Policy and Southeast Asia. New York: St. Martin's Press, 1986.

Buszynski, Leszek. "The Soviet Union and Southeast Asia Since the Fall of Saigon”. Asian Survey 21, no. 5, 1981: 536-550. 
Buzynski, Leszek. "Vietnam Confronts China". Asian Survey 20, no. 8, 1980: 829-843.

Canberra Times. "UN resolution on East Timor 'lacked realism"'. Friday 19 November 1976.

Canberra Times. "Mr Whitlam links the demise of Timor with his own downfall". Saturday 25 September 1976.

Canberra Times. "No lone action on Timor: Peacock". Monday 24 May 1976.

Canberra Times. “ASEAN Concern”. Tuesday 6 January 1976.

Canberra Times. "PM 'knew of plan' before invasion". Thursday 11 December 1975.

Canberra Times. "PM, Razak to discuss future of Brunei". Tuesday 14 October 1975.

Capie, David. "The Responsibility to Protect Norm in Southeast Asia: Framing, Resistance and the Localisation Myth". The Pacific Review 25, no. 1, March 2012: 75-93.

Carter, Ashton. "The United States and Challenges to Asia-Pacific Security”. The Shangri-La Dialogue Report, 30 May 2015, http:// www.iiss.org/en/publications/conference\%20proceedings/sections/ shangri-la-aa36/the-shangri-la-dialogue-2015-8842/sld15-05plenary-1-e16c.

Chachavalpongpun, Pavin. "Embedding Embittered History: Unending Conflicts in Thai-Cambodian Relations". Asian Affairs 43, no. 1, 2012: 81-102.

Chalk, Peter. Australian Foreign and Defense Policy in the Wake of the 1999/2000 East Timor Intervention. Santa Monica, CA: RAND, 2001.

Chambers, Michael. “The Chinese and the Thai are Brothers': The Evolution of the Sino-Thai Friendship". Journal of Contemporary China 14, no. 45, 2005: 599-629.

Chanda, Nayan. Brother Enemy: The War after the War. New York: Harcourt Brace Jovanovich Publishers, 1986.

Chandran, Nyshka. "Even if Trump wants to renegotiate the TPP, members may not bite, says Singapore official". CNBC, 18 April 2018, https://www.cnbc.com/2018/04/18/singapore-ministry-offoreign-affairs-tommy-koh-on-the-trans-pacific-partnership.html.

Channel News Asia. "Philippines hails US as top ally, welcomes war games”. 05 October 2017, http://www.channelnewsasia.com/ news/asiapacific/philippines-hails-us-as-top-ally-welcomes-wargames-9282364.

Chin, Kin Wah, and Leo Suryadinata, ed. Michael Leifer: Selected Works on Southeast Asia. Singapore: Institute of Southeast Asian Studies, 2005. 
Chopra, Janet. "The UN's Kingdom of East Timor". Survival 42, no. 3, Autumn 2000: 27-39.

Ciorciari, John D. The Limits of Alignment: Southeast Asia and the Great Powers since 1975. Washington DC: Georgetown University Press, 2010.

Cloud, David S. "Defense Secretary Ashton Carter warns Beijing on South China Sea island-building”. LA Times, 29 May 2015. http:// www.latimes.com/nation/la-na-ashton-carter-china-20150529-story. html.

CNN Philippines. "Philippines eyes record P25B defense spending for 2016”. 21 July 2015, http:// cnnphilippines.com/news/2015/07/21/ Philippines-proposes-record-P25B-defense-spending-in-2016.html. Consulate-General of the People's Republic of China in Toronto.

“Foreign Ministry Spokesperson Hong Lei’s Regular Press Conference on February 20, 2013, http://toronto.china-consulate. org/eng/fyrthhz/t1015425.htm.

Copeland, Dale. "Economic Interdependence and the Future of U.S.-Chinese Relations". In International Relations Theory and the Asia-Pacific, edited by John G Ikenberry and Michael Mastanduno, 323-352. New York: Columbia University Press, 2003.

Cotton, James. East Timor, Australia and Regional Order: Intervention and its Aftermath in Southeast Asia. New York: Routledge, 2004.

Crawford, Timothy. Pivotal Deterrence: Third-Party Statecraft and the Pursuit of Peace. Ithaca, NY: Cornell University Press, 2003.

Cruz De Castro, Renato. "The Early Duterte Presidency in the Philippines". Journal of Current Southeast Asian Affairs 35, no. 3, 2016: 3-14.

Cruz De Castro, Renato. "Facing up to China's Realpolitik Approach in the South China Sea Dispute: The Case of the 2012 Scarborough Shoal Stand-Off and its Aftermath". Journal of Asian Security 3, no. 2, 2016: 157-182.

Cruz De Castro, Renato. "The Strategic Balance in East Asia and the Small Powers: The Case of the Philippines in the Face of the South China Sea Dispute". Pacific Focus: Inha Journal of International Studies 31, no. 1, 2016: 126-149.

Cruz De Castro, Renato. "The Philippines Confronts China in the South China Sea: Power Politics vs. Liberalism-Legalism”. Asian Perspective 39, no. 1, 2015: 71-100.

Cruz De Castro, Renato. "Adjusting to the Post-US Bases Era: The Ordeal of the Philippine Military's Modernisation Program”. Armed Forces and Society 26, no. 1, 1999: 119-137. 
Dancel, Raul. "Nothing provocative in what the US is doing, says Aquino”. Straits Times, 28 October 2015, http://www.straitstimes. $\mathrm{com} / \mathrm{asia} / \mathrm{se}-\mathrm{asia} /$ nothing-provocative-in-what-the-us-is-doingsays-aquino.

Dibb, Paul. "The Key to South-East Asia's Security". International Affairs 77, no. 4, Oct 2001: 829-842.

Djajamihardja, Hidayat. "A Reporter's View". In Guns and Ballot Boxes: East Timor's Vote for Independence, edited by Damien Kingsbury, 99-115. Victoria: Monash Asia Institute, 2000.

Djalal, Hasjim. "ASEAN Claimant's Position in the South China Sea". In Entering Unchartered Waters? ASEAN and the South China Sea, edited by Pavin Chachavalpongpun, 67-88. Singapore: Institute of Southeast Asian Studies, 2014.

Dollah, Siti Rahil. "Downer warns against Indonesia becoming like Balkans”. Kyodo News, 23 February 1999.

Dore, Christopher. "Unfuriated [sic] neighbours". The Australian, 9 September 1999.

Dori, John T. "Indonesia's Economic and Political Crisis: A Challenge for the US Leadership in Asia". The Heritage Foundation Backgrounder: Executive Summary, 17 August 1998.

Doyle, Michael W. "International Ethics and the Responsibility to Protect”. International Studies Review 13, 2011: 72-84.

Dunn, James. Timor: A People Betrayed. Australia: Jacaranda, 1983.

Dupont, Alan. "ASEAN's Response to the East Timor Crisis". Australian Journal of International Affairs 54, no, 2, 2000: 163-170.

Dupont, Alan. "The Australia-Indonesia Security Agreement". The Australian Quarterly 68, no. 2, Winter 1996: 49-62.

East Timor: Including the Report by James Dunn, Former Australian Consul in Dili. New Zealand University Students' Association for the New Zealand Campaign for an Independent East Timor, August 1977, Wellington.

Elman, Colin. "Horses for Courses: Why Not Neorealist Theories of Foreign Policy?” Security Studies 6, no. 1, 1996: 7-53.

Emmerson, Donald. "Moralpolitik: The Timor Test". National Interest 58, 1999/2000: 63-68.

Fernandes, Clinton. "Recognition as a political act: Political considerations in recognizing Indonesia's annexation of East Timor". In Territorial Separatism in Global Politics: Causes, Outcomes and Resolution, edited by Damien Kingsbury and Costas Laoutides, 93-108. Hoboken, NJ: Taylor and Francis, 2015. 
Fernandes, Clinton. "R2P and the East Timor Intervention". In Responsibility to Protect and Sovereignty, edited by Charles Sampford and Ramesh Thakur, 63-84. Surrey: Ashgate, 2013.

Fernandes, Clinton. "The Road to INTERFET: Bringing the Politics Back In”. Security Challenges 4, no. 3, Spring 2008: 83-98.

Fifield, Anna. "China thinks the trade war isn't really about trade". The Washington Post, 24 September 2018, https://www. washingtonpost.com/world/asia_pacific/china-thinks-the-trade-warisnt-really-about-trade/2018/09/23/67c7b0ec-bb51-11e8-b1c57a2126bc722c_story.html?utm_term=.c7ccbf1aaa77.

Finnemore, Martha. National Interests in International Society. Ithaca, NY: Cornell University Press, 1996.

Forrester, Geoff, and Ronald James May. The Fall of Soeharto. London: C Hurst \& Co, 1998.

Fravel, M Taylor. "China's Strategy in the South China Sea". Contemporary Southeast Asia 33, no. 3, 2011, 292-319.

Frey, Frederick. "The Problem of Actor Designation in Political Analysis”. Comparative Politics 17, no. 2, January 1985: 127-152.

Funston, John "The Third Indochina War and Southeast Asia". Contemporary Southeast Asia 1, no. 3, December 1979: 268-289.

Gallu, Joshua. "Trump's ASEAN summit snub fuels doubts about US commitment". The Sydney Morning Herald, 02 September 2018, https://www.smh.com.au/world/asia/trump-s-asean-summit-snubfuels-doubts-about-us-commitment-20180902-p5019z.html.

Ganesan, Narayanan. “ASEAN's Relations with Major External Powers". Contemporary Southeast Asia 22, no. 2, August 2000: 258-278.

Geddie, John. “Trump's overture to emerging Asia drowned out by trade war". Reuters, 02 August 2018, https://www.reuters.com/ article/us-usa-trade-asean/trumps-overture-to-emerging-asiadrowned-out-by-trade-war-idUSKBN1KN090.

Gerard, Kelly. "Crises, Civil Society and Regionalism in Southeast Asia". In Crisis and Institutional Change in Regional Integration, edited by Sabine Saurugger and Fabien Terpan, 192-208. London: Routledge, 2016.

Ghosh, Nirmal. "Laureate barred from Manila during APEC meet". Straits Times, 22 October 1996.

Ghosh, Nirmal. "Ramos defuses crisis, bans non-Filipinos from meeting”. Straits Times, 21 May 1994.

Glas, Aarie, "Habits of Peace: Long-term regional cooperation in Southeast Asia". European Journal of International Relations 23, no. 4, 2017: 833-856. 
Godwin, Paul HB. "From Continent to Periphery: PLA Doctrine, Strategy and Capabilities Towards 2000”. The China Quarterly 146, 1996: 464-487.

Gomez, Jim. “Duterte says he'll set aside sea feud ruling against China”. Philstar, 17 December 2016,: http://www.philstar.com/ headlines/2016/12/17/1654340/duterte-says-hell-set-aside-seafeud-ruling-against-china.

Grieco, Joseph. "State Interests and Institutional Rule Trajectories: A Neorealist Interpretation of the Maastricht Treaty and European Economic and Monetary Union". Security Studies 5, no. 3, March 1996: 261-306.

Grieco, Joseph. "Realist Theory and the Problem of International Cooperation: Analysis with an Amended Prisoner's Dilemma Model”. The Journal of Politics 50, no. 3, 1988: 600-624.

Gruber, Lloyd. Ruling the World: Power Politics and the Rise of Supranational Institutions. Princeton, NJ: Princeton University Press, 2000.

Guardian. "Serious military provocation': China angered by US presence in South China Sea”. 03 July 2017, https://www. theguardian.com/world/2017/jul/03/serious-military-provocationchina-angered-by-us-presence-in-south-china-sea.

Guardian. "Obama says China bullying smaller nations in South China Sea row". 10 April 2015, https://www.theguardian.com/ world/2015/apr/10/obama-says-china-bullying-smaller-nations-insouth-china-sea-row.

Gupta, Sourabh. "China scores with ASEAN play as Trump's America loses its way in South China Sea". South China Morning Post, 03 August 2018, https://www.scmp.com/week-asia/geopolitics/ article/2158203/china-scores-asean-play-trumps-america-loses-itsway-south.

Haacke, Jürgen. ASEAN'S Diplomatic and Security Culture. London: RoutledgeCurzon, 2003.

Haacke, Jürgen. "ASEAN's Diplomatic and Security Culture: a Constructivist Assessment". International Relations in the Asia-Pacific 3, no. 1, 2003: 57-87.

Hai, Do Thanh. Vietnam and the South China Sea: Politics, Security and Legality. New York: Routledge, 2017.

Handel, Michael. Weak States in the International System. London: Frank Cass, 1981.

Hanhimäki, Jussi. The Flawed Architect: Henry Kissinger and American Foreign Policy. Oxford: Oxford University Press, 2004.

Hansen, Gary. "Indonesia 1975: National Resilience and Continuity of the New Order Struggle”. Asian Survey 16, no. 2, 1976: 146-158. 
Haq, Farhan. "Mahathir calls for reduced Australian presence in Timor”. Asia Times Online, 01 October 1999.

Hayton, Bill. "The Week Donald Trump Lost the South China Sea”. Foreign Policy, 31 July 2017, http://foreignpolicy.com/2017/07/31/ the-week-donald-trump-lost-the-south-china-sea/.

Hayton, Bill. "South China Sea: Vietnam halts drilling after 'China threats"”. BBC News, 24 July 2017, http://www.bbc.com/news/ world-asia-40701121.

Hayton, Bill. The South China Sea: The Struggle for Power in Asia. New Haven, CT: Yale University Press, 2014.

Henry, Iain. 'Unintended consequences: an examination of Australia's 'historic policy shift' on East Timor'. Australian Journal of International Affairs 68, no. 1, 2014: 45-68.

Henry, Iain. "Playing Second Fiddle on the Road to INTERFET: Australia's East Timor Policy Throughout 1999”. Security Challenges 9, no. 1, 2013: 87-111.

Heydarian, Richard Javad. "Tragedy of Small Power Politics: Duterte and the Shifting Sands of Philippine Foreign Policy". Asian Security, 13, no.3 (2017): 220-236.

Heydarian, Richard Javad. "Has Duterte's China engagement backfired?" Asia Times, 14 July 2017, http://www.atimes.com/ article/dutertes-china-engagement-backfired/.

Hoadley, Stephen. "East Timor: Civil War-Causes and Consequences". Southeast Asian Affairs, 1976: 411-419.

Holmes, Oliver. "Trump skips East Asia Summit on final day of 12-day tour”. The Guardian, 14 November 2017, https://www.theguardian. com/us-news/2017/nov/14/donald-trump-skips-east-asia-summiton-final-day-of-12-day-tour.

Holmes, Oliver. "Trump hails 'great relationship' with Philippines' Duterte". The Guardian, 13 November 2017, https://www. theguardian.com/us-news/2017/nov/13/trump-hails-greatrelationship-with-philippines-duterte.

Holzgrefe, JL. "The humanitarian intervention debate". In Humanitarian Intervention. Ethical, Legal and Political Dilemmas, edited by JL Holzgrefe and Robert O Keohane, 15-52. Cambridge: Cambridge University Press, 2003.

Hunt, Katie, and Kathy Quiano. "South China Sea: China building more islands?" CNN, 08 September 2016, http://edition.cnn. com/2016/09/08/asia/south-china-sea-scarborough-shoalphilippines-china/index.html.

Inbaraj, Sonny. "ASEAN's commitment to East Timor faces tough test”. Asia Times Online, 01 February 2000. 
Indonesia Diplomatic Handbook. 5th ed. Washington DC, International Business Publications, 2008.

Jacob, Paul. "Alatas hails Philippines' decision”. Straits Times, 21 May 1994.

Jacob, Paul. "Alatas warns Manila not to allow East Timor meeting". Straits Times, 17 May 1994.

Jacob, Paul. "Australia and Indonesia strengthen bilateral ties". Straits Times, 18 November 1992.

Jaipragas, Bhavan. "ASEAN and China have moved on ... Didn't Vietnam get the memo?" South China Morning Post, 13 August 2017, http://www.scmp.com/week-asia/geopolitics/article/2106469/ asean-and-china-have-moved-ondidnt-vietnam-get-memo.

Jakarta Post. "Anti-Indonesia Protests Held in Australia over East Timor”. 7 September 1999.

Jakarta Post. "EU warned not to scrutinise East Timor". 1 December 1996.

Jakarta Post. "Indonesia appreciates Malaysian Attitude". 12 November 1996.

Japan Times. "As attention focuses on North Korean threat, Beijing quietly expanding South China Sea militarisation”. 01 November 2017, https://www.japantimes.co.jp/news/2017/11/01/asia-pacific/ attention-focuses-north-korea-threat-beijing-quietly-expandingsouth-china-sea-militarization/\#.WiazWLSFjeQ.

Jenkins, David. "Australia's helping hand in Indonesia's military muscle”. Sydney Morning Herald, 04 December 1995.

Jho, Whasun, and Soo A Chae. "Hegemonic Disputes and the Limits of the ASEAN Regional Forum”. Pacific Focus: Inha Journal of International Studies 29, no. 2, 2014: 237-259.

Jiangtao, Shi, and Liu Zhen. "'Better left untouched': Philippines and Vietnam wary of Trump offer to mediate South China Sea disputes". South China Morning Post, 12 November 2017, http://www.scmp. com/news/china/diplomacy-defence/article/2119551/better-leftuntouched-philippines-and-vietnam-wary.

Jiangtao, Shi. 'Has Beijing really 'turned the page' on South China Sea ruling?" South China Morning Post, 09 September 2016, http:// www.scmp.com/news/china/diplomacy-defence/article/2018038/ has-beijing-really-turned-page-south-china-sea-ruling.

Job, Brian L, and Anastasia Shesterinina. "China as a Global NormShaper: Institutionalisation and Implementation of the Responsibility to Protect". In Implementation and World Politics, edited by Alexander Betts and Phil Orchard, 144-159. Oxford: Oxford University Press, 2014. 
Johnson, Jesse. "Beijing continuing 'steady pattern of militarisation' in South China Sea”. Japan Times, 24 February 2017, https://www. japantimes.co.jp/news/2017/02/24/asia-pacific/beijing-continuingsteady-pattern-militarization-south-china-sea/\#.WiQZnbSFjeQ.

Johnson, Tim. "ASEAN wants East Timor crisis tackled by Indonesia, UN” Kyodo News, 09 September 1999.

Johnston, Alastair Ian, and Robert S Ross. “Conclusion”. In Engaging China: The Management of an Emerging China, edited by Alastair Ian Johnston and Robert S Ross, 273-296. New York: Routledge, 1999. Joint Statement of the RP-PRC Consultations on the South China Sea and on Other Areas of Cooperation, 9-10 August 1996. In International Law in East Asia, edited by Zou Keyuan and Jianfu Chen. New York: Routledge, 2016.

Jones, David, Nicholas Khoo, and MLR Smith. Asian Security and the Rise of China: International Relations in an Age of Volatility. Cheltenham: Edward Elgar, 2013.

Jones, David M, and Michael LR Smith. "Constructing Communities: The Curious Case of East Asian Regionalism". Review of International Studies 33, no. 1, 2007: 165-186.

Jones, David M, and Michael LR Smith. "Making Process, Not Progress". International Security 32, no. 1, Summer 2007: 148-184.

Jones, David M, and Michael LR Smith. ASEAN and East Asian International Relations: Regional Delusion. Cheltenham: Edward Elgar, 2006.

Jones, David M, and Michael LR Smith. "ASEAN's Imitation Community". ORBIS 46, no. 1, Winter 2002: 93-109.

Jones, Lee. "Sovereignty, Intervention, and Social Order in Revolutionary Times". Review of International Studies 39, no. 1, 2013 : 1149-1167.

Jones, Lee. ASEAN, Sovereignty and Intervention in Southeast Asia. New York: Palgrave Macmillan, 2012.

Kaiman, Jonathan. "China accuses Vietnam of ramming its ships in South China Sea". The Guardian, 8 May 2014, https://www. theguardian.com/world/2014/may/08/china-accuses-vietnam-shipssouth-china-sea-oil-rig.

Kaplan, Robert D. "How President Trump is helping Beijing win in the South China Sea". The Washington Post, 09 October 2018, https:// www.washingtonpost.com/news/global-opinions/wp/2018/10/09/ how-president-trump-is-helping-beijing-win-in-the-south-chinasea/?noredirect $=$ on\&utm_term $=.556 \mathrm{cb} 534 \mathrm{ba} 9 \mathrm{e}$.

Kaplan, Robert D. Asia's Cauldron: The South China Sea and the End of a Stable Pacific. New York: Random House, 2014. 
Khmer Times. "China Gives \$600 Million After South China Sea Support”. 15 July 2016, http://www.khmertimeskh.com/ news/27292/china-gives-600-million-after-south-china-seasupport/.

Khoo, Nicholas. Collateral Damage: Sino-Soviet Rivalry and the Termination of the Sino-Vietnamese Alliance. New York: Columbia University Press, 2011.

Khoo, Nicholas. "Deconstructing the ASEAN Security Community: A Review Essay". International Relations of the Asia-Pacific 4, no. 1, 2004: 35-46.

Kiernan, Ben. Genocide and Resistance in Southeast Asia. London: Transaction, 2008.

Kiernan, Ben. How Pol Pot Came to Power: Colonialism, Nationalism, and Communism in Cambodia, 1930-1975. 2nd ed. New Haven, CT: Yale University Press, 2004.

Kiernan, Ben. "The Demography of Genocide in Southeast Asia: The Death Tolls in Cambodia, 1975-79, and East Timor, 1975-80". Critical Asian Studies 35, no. 4, 2003: 585-597.

Kiernan, Ben. The Pol Pot Regime: Race, Power, and Genocide in Cambodia under the Khmer Rouge, 1975-79. New Haven, CT: Yale University Press, 1996.

King, Gary, Robert O. Keohane, and Sidney Verba. Designing Social Inquiry: Scientific Inference in Qualitative Research. Princeton, NJ: Princeton University Press, 1994.

Kingsbury, Damien. East Timor: The Price of Liberty. New York: Palgrave Macmillan, 2009.

Kingsbury, Damien. Power Politics and the Indonesian Military. New York: RoutledgeCurzon, 2003.

Kissinger Transcripts. A Verbatim Record of US Diplomacy 1969-1977. The Digital National Security Archive, KT00663, http://gateway. proquest.com/openurl?url_ver=Z39.88-2004\&res_dat=xri:dnsa\&rft_ dat $=$ xri:dnsa:article:CKT00663.

Krasner, Stephen. "Rethinking the Sovereign State Model". Review of International Studies 27, no. 5, December 2001: 17-42.

Krasner, Stephen. Sovereignty: Organized Hypocrisy. Princeton, NJ: Princeton University Press, 1999.

Krasner, Stephen. "Sovereignty and Intervention". In Beyond Westphalia? State Sovereignty and International Intervention, edited by Gene M Lyons and Michael Mastanduno, 228-249. Baltimore: Johns Hopkins University Press, 1995. 
Krasner, Stephen. Defending the National Interest: Raw Materials Investments and US Foreign Policy. Princeton, NJ: Princeton University Press, 1978.

Kuok, Lynn. "The US FON program in the South China Sea". Brookings Centre for East Asia Policy Studies, East Asia Policy Paper 9, June 2016.

Kyodo News. "Japan, US welcome East Timor result, ASEAN cautious". 5 September 1999.

Kyodo News. "East Timor changes future for ASEAN, Indonesia". 4 September 1999.

Lake, David A. Hierarchy in International Relations. New York: Cornell University Press, 2009.

Lawless, Robert. "The Indonesian Takeover of East Timor". Asian Survey 16, no. 10 (1976): 948-64.

Lee, Kuan Yew. From Third World to First, The Singapore Story: 19652000. New York: HarperCollins, 2000.

Leifer, Michael. "Regional Solutions to Regional Problems?" In Towards Recovery in Pacific Asia, edited by Gerald Segal and David SG Goodman, 108-118. London: Routledge, 2000.

Leifer, Michael. Singapore's Foreign Policy: Coping with Vulnerability. London: Routledge, 2000.

Leifer, Michael. "Stalemate in the South China Sea". In Perspectives on the Conflict in the South China Sea, edited by K Snildal. Oslo: Centre for Development and the Environment, 1999.

Leifer, Michael. "The ASEAN Peace Process: A Category Mistake". The Pacific Review 12, no. 1, 1999: 25-38.

Leifer, Michael. "Southeast Asia". In The Oxford History of the Twentieth Century, edited by Michael Howard and Wm Roger Louis, 227-239. Oxford: Oxford University Press, 1998.

Leifer, Michael. ASEAN and the Security of South-East Asia. London: Routledge, 1989.

Leifer, Michael. "ASEAN's Search for Regional Order". Faculty of Arts and Social Sciences Lecture 12, National University of Singapore, 1987.

Leifer, Michael. Conflict and Regional Order in Southeast Asia. Adelphi Paper No. 162. London: International Institute for Strategic Studies, 1980.

Leifer, Michael. "Post Mortem on the Third Indochina War". The World Today 35, no. 6, 1979: 249-258.

Leifer, Michael. "Indonesia and the Incorporation of East Timor". The World Today 32, no. 9, 1976: 347-354. 
Lum, Thomas, and Wayne M. Morrison and Bruce Vaughn. "CRIS Report for Congress: China's "Soft Power" in Southeat Asia". 04 January 2008, Order Code RL34310, CRS-9, https://fas.org/ sgp/crs/row/RL34310.pdf.

Maley, William. "Australia and the East Timor Crisis: Some Critical Comments". Australian Journal of International Affairs 54, no. 2, 2000 : 151-162.

Manibhandu, Anuraj. "Thailand shuns ceremony". Bangkok Post, 10 December 1996.

Mann, Michael. "The Autonomous Power of the State: its Origins, Mechanisms and Results". European Journal of Sociology 25, no. 2, November 1984: 185-213.

Manne, Robert. The Howard Years. Melbourne: Black Inc. Agenda, 2004.

Mansfield, Edward D. "International Institutions and Economic Sanctions". World Politics 47, no. 44, 1995: 575-605.

Mason, Jeff, and Bruce Wallace. "Obama, ASEAN discuss South China Sea tensions, but no joint mention of China". Reuters, 16 February 2016, https://www.reuters.com/article/us-usa-asean/obama-aseandiscuss-south-china-sea-tensions-but-no-joint-mention-of-chinaidUSKCNOVP1F7.

Mattheis, Frank, and Uwe Wunderlich. "Regional actorness and interregional relations: ASEAN, the EU and Mercosur". Journal of European Integration 39, no. 6, 2017: 723-738.

McCarthy, Terry. "Reef wars". Time. 08 March 1999, http://content. time.com/time/world/article/0,8599,2054240,00.html.

McCloskey, Stephen. "Introduction: East Timor - From European to Third World Colonialism”. In The East Timor Question: The Struggle for Independence from Indonesia, edited by Paul Hainsworth and Stephen McCloskey, 1-16. London: Tauris, 2000.

Mearsheimer, John. "Structural Realism". In International Relations Theories: Discipline and Diversity 3rd ed., edited by Tim Dunne, Milja Kurki and Steve Smith, 77-93. Oxford: Oxford University Press, 2013.

Mearsheimer, John. The Tragedy of Great Power Politics. New York: WW Norton \& Co., 2001.

Mearsheimer, John. "The False Promise of International Institutions". International Security 19, no. 3, Winter 1994/1995: 5-49.

Merom, Gil. "Realist Hypotheses on Regional Peace". Journal of Strategic Studies 26, no. 1, 2003: 109-135. 
Mill, John Stuart. "A Few Words on Non-Intervention". In Essays on Politics and Culture, edited by Gertrude Himmelfarb, 368-384. Gloucester: Peter Smith, 1973.

Ministry of Foreign Affairs of the People's Republic China. "Foreign Ministry Spokesperson Hong Lei’s Remarks on Vietnam's Statement on the Chinese Government's Position Paper on Rejecting the Jurisdiction of the Arbitral Tribunal Established at the Request of the Philippines for the South China Sea Arbitration”. 12 December 2014, http://www.fmprc.gov.cn/mfa_eng/xwfw_665399/s2510_665401/ t1218756.shtml.

Ministry of Foreign Affairs of the People's Republic of China. "Position Paper of the Government of the People's Republic of China on the Matter of Jurisdiction in the South China Sea Arbitration Initiated by the Republic of the Philippines". 7 December 2014, http://www. fmprc.gov.cn/mfa_eng/zxxx_662805/t1217147.shtml.

Ministry of Foreign Affairs of Vietnam. "Remarks by MOFA Spokesperson Le Hai Binh on the South China Sea Arbitration Case". 11 December 2014, http://www.mofa.gov.vn/en/tt_baochi/pbnfn/ ns141212143709.

Moe, Terry M. "Power and Political Institutions". Perspectives on Politics 3, no. 2, 2005: 215-233.

Mogato, Manuel, and Christian Shepherd. "Australia, Japan, U.S. call for South China Sea code to be legally binding". Reuters, 07 August 2017, https://www.reuters.com/article/us-asean-philippinessouthchinasea-idUSKBN1AN0TU.

Mogato, Manuel. "Duterte says China's Xi threatened war if Philippines drills for oil". Reuters, 19 May 2017, https://www.reuters.com/ article/us-southchinasea-philippines-china/duterte-says-chinasxi-threatened-war-if-philippines-drills-for-oil-idUSKCN18F1DJ. Accessed 17 November 2017.

Mogato, Manuel. "US triples military aid to Philippines in 2012". Reuters, 03 May 2012, https://www.reuters.com/article/usphilippines-usa/u-s-triples-military-aid-to-philippines-in-2012idUSBRE8420IU20120503.

Mogato, Manuel, Michael Martina, and Ben Blanchard. "ASEAN Deadlocked on South China Sea, Cambodia Blocks Statement". Reuters, 25 July 2016, https://www.reuters.com/article/ussouthchinasea-ruling-asean/asean-deadlocked-on-south-china-seacambodia-blocks-statement-idUSKCN1050F6. 
Morgan, David. "US says Chinese vessels harassed Navy ship". Reuters, 09 March 2009. https://www.reuters.com/article/ us-usa-china-navy/u-s-says-chinese-vessels-harassed-navy-shipidUSTRE52845A20090309.

Morgenthau, Hans. Politics Among Nations. 4th ed. New York: Alfred Knopf, 1967.

Morris, Stephen. Why Vietnam Invaded Cambodia: Political Culture and the Causes of War. Stanford, CA: Stanford University Press, 1999.

Nair, KK. ASEAN-Indochina Relations Since 1975: The Politics of Accommodation. Canberra Papers on Strategy and Defence Number 30. Canberra: ANU, 1984.

Nanto, Dick K. “The 1997-98 Asian Financial Crisis". CRS Report for Congress No. 97-1021 E, updated 06 February 1998.

Narine, Shaun. Explaining ASEAN: Regionalism in Southeast Asia. London: Lynne Rienner, 2002.

National Security Archive. "Digitized Set of 2,100 Henry Kissinger "Memcons" Recounting the Secret Diplomacy of the Nixon-Ford Era". In National Security Archive Briefing Book No.193, edited by William Burr, 26 May 2006, http://nsarchive.gwu.edu/NSAEBB/ NSAEBB193/.

National Security Archive. "A Quarter Century of US Support for Occupation”. In National Security Archive Briefing Book No.174, edited by Brad Simpson, 28 November 2005, http://nsarchive.gwu.edu/ NSAEBB/NSAEBB174/\#doc23.

National Security Archive. "East Timor Revisited". In National Security Archive Briefing Book No.62, edited by William Burr and Michael L. Evans, 6 December 2001, http://nsarchive.gwu.edu/NSAEBB/ NSAEBB62/.

Ngo, Huyn. "Trade with Indonesia and the Philippines". Northern Territory of Australia Department of Primary Industry and Fisheries, Technical Bulletin No.258, March 1997.

Nicol, Bill. Timor: A Nation Reborn. Equinox Publishing Ltd: Indonesia, 2002.

Nobel Peace Prize Press Release, Oslo, 11 October 1996.

Noland, Marcus. "The Philippines in the Asian Financial Crisis: How the Sick Man Avoided Pneumonia”. Asian Survey 40, no. 3, 2000: 401-412.

O'Dowd, Edward. Chinese Military Strategy in the Third Indochina War: The Last Maoist War. London: Routledge, 2007.

Ortigas, Marga. "Scarborough Shoal stand-off sparks protests". Al Jazeera, 13 May 2012, http://www.aljazeera.com/indepth/ features/2012/05/2012512191343212584.html. 
Pape, Robert A. "When Duty Calls: A Pragmatic Standard of Humanitarian Intervention”. International Security 37, no. 1, Summer 2012: 41-80.

Parliament of the Commonwealth of Australia. East Timor: Final Report of the Senate Foreign Affairs, Defence and Trade References Committee. Canberra: Senate Printing Unit, December 2000.

Path, Kosal. "China's Economic Sanctions against Vietnam, 19751978”. The China Quarterly 212, December 2012: 1040-1058.

Peou, Sorpong. Human Security in East Asia: Challenges for Collaborative Action. London: Routledge, 2008.

Periera, Derwin. "After Trump victory, uncertainty in Asia. If America retreats, will it be China to the fore?" Straits Times, 09 November 2016, http://www.straitstimes.com/opinion/after-trump-victoryuncertainty-in-asia-if-america-retreats-will-it-be-china-to-the-fore.

Perlez, Jane. "China and Vietnam Point Fingers After Clash in the South China Sea”. New York Times, 27 May 2014, https://www. nytimes.com/2014/05/28/world/asia/vietnam.html.

Perlez, Jane. "Philippines and China Ease Tensions in Rift at Sea". New York Times, 18 June 2012, http://www.nytimes.com/2012/06/19/ world/asia/beijing-and-manila-ease-tensions-in-south-china-sea. html.

Permanent Court of Arbitration. "Press Release: The South China Sea Arbitration. The Republic of the Philippines v. The People's Republic of China". The Hague, 12 July 2016, https://pca-cpa.org/ wp-content/uploads/sites/175/2016/07/PH-CN-20160712-PressRelease-No-11-English.pdf.

Permanent Court of Arbitration Award. "In the Matter of the South China Sea Arbitration before an Arbitral Tribunal Constituted Under Annex VII to the 1982 United Nations Convention on the Law of the Sea between the Republic of the Philippines and the People's Republic of China”. PCA Case No. 2013-19, 12 July 2016, 2, https://pca-cpa.org/wp-content/uploads/sites/175/2016/07/PHCN-20160712-Award.pdf.

Petty, Martin. "Philippine leader tells Obama 'to go hell', says can buy arms from Russia, China”. Reuters, 04 October 2016, http://www.reuters.com/article/us-philippines-duterte-arms/ philippine-leader-tells-obama-go-to-hell-says-can-buy-arms-fromrussia-china-idUSKCN12414A?utm_content=bufferb48b7\&utm_ medium $=$ social\&utm_source $=$ twitter.com\&utm_campaign=buffer. 
Petty, Martin. "Duterte declares upcoming Philippine-US war games 'the last one". Reuters, 28 September 2016, https://www.reuters. $\mathrm{com} /$ article/us-philippines-duterte/duterte-declares-upcomingphilippines-u-s-war-games-the-last-one-idUSKCN11Y1ZI.

Pham, My. "Vietnam pushes back after threats from Beijing over drilling in the South China Sea". Business Insider, 28 July 2017, http:// www.businessinsider.com/r-vietnam-says-others-should-respect-itsright-to-drill-for-south-china-sea-oil-2017-7.

Philstar. "Full Text: Obama on South China Sea, defense alliance with Philippines”. 18 November 2015, http://www.philstar.com/ headlines/2015/11/18/1523292/full-text-obama-south-china-seadefense-alliance-philippines.

Pietsch, Sam. "Australian Imperialism and East Timor". Marxist Interventions 2, 2010: 7-38.

Pike, Douglas. Vietnam and the Soviet Union: Anatomy of an Alliance. London: Westview Press, 1987.

Pike, Douglas. "Communist vs. Communist in Southeast Asia". International Security 41, no. 1, Summer, 1979: 20-39.

Pollard, Vincent K. “ASA and ASEAN, 1961-1967: Southeast Asian Regionalism”. Asian Survey 10, no. 3, 1970: 244-255.

Press, Daryl G. Calculating Credibility: How Leaders Assess Military Threats. Ithaca, NY: Cornell University Press, 2005.

Prime Minister's Office Singapore. "PM Lee Hsien Loong's interview with Wall Street Journal on 29 March 2016”. 29 March 2016, http:// www.pmo.gov.sg/newsroom/pm-lee-hsien-loongs-interview-wallstreet-journal-wsj.

Prime Minister's Office Singapore. Speech by Mr Lee Kuan Yew, Minister Mentor, at the S Rajaratnam Lecture, 09 April 2009, $5.30 \mathrm{pm}$ at Shangri-La Hotel, https://www.pmo.gov.sg/newsroom/ speech-mr-lee-kuan-yew-minister-mentor-s-rajaratnam-lecture-09april-2009-530-pm-shangri.

Radio Free Asia. "ASEAN, Beijing Agree to Talks on South China Sea Code". 06 August 2017, http://www.rfa.org/english/news/china/ asean-scs-08062017182346.html.

Ramos-Horta, José Manuel. Funu: The Unfinished Saga of East Timor. Trenton NJ: Red Sea Press, 1987.

Rathbun, Brian. "A Rose by Any Other Name: Neoclassical Realism as the Logical and Necessary Extension of Structural Realism”. Security Studies 17, no. 2, 2008: 294-321. 
Republic of the Philippines Department of Foreign Affairs. "Notification and Statement of Claim”. No. 13-0211, 22 January 2013. https:// www.dfa.gov.ph/images/UNCLOS/Notification\%20and\%20 Statement\%20of\%20Claim\%20on\%20West\%20Philippine\%20Sea. pdf.

Republic of Singapore Ministry of Foreign Affairs. "MFA Spokesman's comments In response to media queries on the Philippines' initiation of arbitration proceedings against China under Article 287 and V II of the 1982 United Nations Convention on the Law of the Sea (UNCLOS)". 23 January 2013, https://www. mfa.gov.sg/content/mfa/overseasmission/asean/press_statements_ speeches/2013/201301/press_20130123.html.

Reuters. "China upset at Mattis' "irresponsible remarks" on South China Sea”. 05 June 2017, https://www.reuters.com/article/usasia-security-china/china-upset-at-mattis-irresponsible-remarks-onsouth-china-sea-idUSKBN18W00U.

Reuters. "Philippines offers eight bases to US under new military deal". 13 January 2016, https://www.reuters.com/article/us-philippinesusa-bases/philippines-offers-eight-bases-to-u-s-under-new-militarydeal-idUSKCNOUR17K20160113.

Reuters. "US starts its first Agent Orange cleanup in Vietnam". 09 August 2012, https://www.reuters.com/article/us-vietnam-usaagentorange/u-s-starts-its-first-agent-orange-cleanup-in-vietnamidUSBRE87803K20120809.

Richardson, JL. "Problems of Australian Foreign Policy: January to June 1976". Australian Journal of Politics and History 22, 1976: 327-337.

Richardson, Michael. "Chinese Gambit: Seizing Spratly Reef Without a Fight”. New York Times, 17 February 1995. http://www.nytimes. com/1995/02/17/news/17iht-sprat_1.html.

Robinson, Geoffrey. If You Leave us Here, We Will Die: How Genocide was Stopped in East Timor. Princeton, NJ: Princeton University Press, 2010.

Robinson, Geoffrey. "People's War: Militias in East Timor and Indonesia”. South East Asia Research 9, no. 3, 2001: 271-318.

Roff, Sue. Timor's Anschluss: Indonesian and Australian Foreign Policy in East Timor, 1974-1976. Lampeter: Edwin Mellen Press, 1992.

Rose, Gideon. "Neoclassical Realism and Theories of Foreign Policy”. World Politics 51, no. 1, 1998: 144-172.

Ross, Robert S. "Navigating the Taiwan Strait: Deterrence, Escalation, Dominance, and U.S.-China Relations". International Security 27, no. 2, 2002: 48-85. 
Ross, Robert. "China and the Cambodian Peace Process: The Value of Coercive Diplomacy". Asian Survey 31, no. 12, 1991: 1170-1185. $R T$. "'We can't afford war': Duterte recommends leaving South China Sea alone, Trump offers mediation”. 12 November 2017, https:// www.rt.com/news/409620-duterte-war-south-china-sea/.

Rüland, Jürgen. "Inter- and Transregionalism; Remarks on the State of the Art of a New Research Agenda". National Europe Centre Paper 35, Paper prepared for the workshop on Asia-Pacific Studies in Australia and Europe: A Research Agenda for the Future, ANU, July 5-6, 2002. Rüland, Jürgen. "ASEAN and the Asian Crisis: Theoretical Implications and Practical Consequences for Southeast Asian Regionalism". The Pacific Review 13, no. 3, 2000: 421-451.

Sabillo, Kristine Angeli. "PH, Vietnam ink closer defense ties". Inquirer, 17 November 2015, http://globalnation.inquirer.net/131451/phvietnam-sign-statement-on-strategic-partnership-amid-disputes-insouth-china-sea.

Salla, Michael. "Australian Foreign Policy and East Timor". Australian Journal of International Affairs 49, no. 2, 1995: 207-222.

Scheiner, Charles. "The United States: From Complicity to Ambiguity". In The East Timor Question: The Struggle for Independence from Indonesia, edited by Paul Hainsworth and Stephen McCloskey, 117-32. London: Tauris, 2000.

Schelling, Thomas. "An Essay on bargaining". The American Economic Review 46, no. 3, 1956: 281-306.

Schweller, Randall, and David Priess. "A Tale of Two Realisms: Expanding the Institutions Debate". Mershon International Studies Review 41, no. 1, May 1997: 1-32.

Schweller, Randall, and William Wohlforth. "Power test: Evaluating realism in response to the end of the Cold War". Security Studies 9, no. 3, 2000: 60-107.

Scoop Independent News. "Australia to Become America's Peacekeeping Deputy”. 23 September 1999.

Senate Resolution 237. "Expressing the Sense of the Senate Regarding the Situation in Indonesia and East Timor". Senate, 22 May 1998, Congressional Record Page S5459, http://etan.org/action/237sres. htm. 
Severino, Rodolfo C. "Sovereignty, Intervention and the ASEAN Way”. Address given at the ASEAN Scholars' Roundtable organised by the Konrad Adenauer Foundation and the Singapore Institute of International Affairs, Singapore, 3 July 2000, http://www.asean. org/resources/2012-02-10-08-47-56/speeches-statements-of-theformer-secretaries-general-of-asean/item/sovereignty-interventionand-the-asean-way-3-july-2000.

Severino, Rodolfo C. "ASEAN Beyond Forty: Towards Political and Economic Integration”. Contemporary Southeast Asia 29, no. 3, 2007 : 406-423.

Shari, Michael. "Commentary: For Suharto, A Most Dangerous Game”. Bloomberg Businessweek, 22 March 1998.

Sidell, Scott. "The United States and Genocide in East Timor". Journal of Contemporary Asia 11, no. 1, 1981: 44-61.

Sim, Susan. "Jakarta Thanks KL for closing Timor Meet". Straits Times, 12 November 1996.

Simon, Sheldon. "The Superpowers in Southeast Asia: A Security Assessment". In Southeast Asia Divided: The ASEAN-Indochina Crisis, edited by Donald Weatherbee, 65-81. Boulder: Westview Press, 1985.

Simon, Sheldon. "The Two Southeast Asias and China: Security Perspectives”. Asian Survey 24, no. 5, 1984: 519-534.

Simpson, Bradley. 'Denying the 'First Right': The United States, Indonesia, and the Ranking of Human Rights by the Carter Administration, 1976-1980". The International History Review 31, no. 4, 2009: 798-826.

Simpson, Bradley. "Illegally and Beautifully: The United States, the Indonesian Invasion of East Timor and the International Community, 1974-76”. Cold War History 5, no. 3, August 2005: 281-315.

Singh, Bilveer. "Reports on East Timor not yet neutral". Jakarta Post, 29 November 1994.

Southgate, Laura. "ASEAN and the Dynamics of Resistance to Sovereignty Violation: The Case of the Third Indochina War, 1978-1991". Journal of Asian Security and International Affairs 2, no. 2, 2015: 200-221.

Southgate, Laura and Nicholas Khoo. "Enter the Vanguard State: Reinterpreting ASEAN's Response to the South China Sea Issue". Journal of Asian Security and International Affairs 3, no. 2, 2016: 221-244. Stinchcombe, Arthur. Constructing Social Theories. New York: Harcourt, Brace \& World Inc., 1968. 
Storey, Ian. "Rising Tensions in the South China Sea: Southeast Asian Responses". In The South China Sea Dispute: Navigating Diplomatic and Strategic Tensions, edited by Ian Storey and Lin Cheng-yi, 134-161. Singapore: ISEAS - Yusof Ishak Institute, 2016.

Storey, Ian. "Japan's maritime security interests in Southeast Asia and the South China Sea dispute". Political Science 65, no. 2, 2013: 135-156.

Storey, Ian. Southeast Asia and the Rise of China: The Search for Security. London: Routledge, 2011.

Storey, Ian. The United States and ASEAN-China Relations: All Quiet on the Southeast Asian Front. Carlisle Barracks, PA: Strategic Studies Institute, US Army War College, October 2007.

Storey, Ian, and Cheng-yi Lin. "Introduction". In The South China Sea Dispute: Navigating Diplomatic and Strategic Tensions, edited by Ian Storey and Lin Cheng-yi, 1-21. Singapore: ISEAS - Yusof Ishak Institute, 2016.

Straits Times. "Philippines and Vietnam to be "strategic partners". 04 September 2015, http://www.straitstimes.com/asia/philippinesand-vietnam-to-be-strategic-partners.

Straits Times. "Human-rights issue "will not impair US-Indonesia ties"”. 04 March 1994.

Straits Times. "Ties with Jakarta on the mend, say US senators". 24 April 1992.

Sukma, Rizal. Indonesia and China: The Politics of a Troubled Relationship. London: Routledge, 1999.

Sutter, Robert, and Chin-hao Huang. "China-Southeast Asia Relations: China Gains and Advances in South China Sea". Comparative Connections 14, no. 3, 2012: 1-9.

Suryodiningrat, Medyatama. "EU dodges East Timor issue in talks". Jakarta Post, 14 February 1997.

Sutter, Robert, and Chin-hao Huang. "China-Southeast Asia Relations: China Gains and Advances in South China Sea”. Comparative Connections 14, no. 3, 2012: 69-77.

Swaine, Michael D. “China's Assertive Behaviour. Part One: On Core Interests”. China Leadership Monitor, Carnegie Endowment for International Peace, 15 November 2010.

Sydney Morning Herald. "Jakarta's bungled Timor diplomacy". 10 June 1994.

Taliaferro, Jeffrey. Balancing Risks: Great Power Intervention in the Periphery. Ithaca, NY: Cornell University Press, 2004.

Tan, Andrew TH. Security Strategies in the Asia-Pacific: The United States' "Second Front" in Southeast Asia. New York: Palgrave Macmillan, 2011. 
Tan, See Seng. "Providers not Protectors: Institutionalising Responsible Sovereignty in Southeast Asia”. Asian Security 7, no. 3, 2011: 201-217. Tang Siew Mun. "What is at stake for ASEAN?" ISEAS Yusof Ishak Institute: ASEAN Focus Special Issue on the South China Sea Arbitration, Responses and Implications, July 2016, 16, ISSN: 2424-8045, https:// iseas.edu.sg/images/pdf/ASEANFocusSChinaSeaArbitration.pdf.

Thayer, Carlyle A. "ASEAN, China and the Code of Conduct in the South China Sea”. SAIS Review of International Affairs 33, no. 2, 2013: 75-84.

Thayer, Carlyle A. "Vietnam's Defensive Diplomacy". Wall Street Journal, 19 August 2010, https://www.wsj.com/articles/SB100014 24052748703649004575438474083884494.

Thies, Cameron. "State Socialisation and Structural Realism". Security Studies 19, no. 4, 2010: 689-717.

Torbati, Yeganeh. "US announces ramped-up military presence in Philippines”. Reuters, 14 April 2016, https://www.reuters.com/ article/us-southchinasea-philippines-carter/u-s-announces-rampedup-military-presence-in-philippines-idUSKCNOXB0QY.

Turley, William, and Jeffrey Race. "The Third Indochina War". Foreign Policy 38, Spring 1980: 92-116.

United Nations Charter. "Chapter I: Purposes and Principles". Article 2.

United Nations Department of Peacekeeping Operations and Department of Field Support. "United Nations Peacekeeping Operations: Principles and Guidelines". Peacekeeping Best Practices Section, January 2008, 1-100.

United Nations General Assembly. "2005 World Summit Outcome”. Resolution A/60/L.1, 24 October 2005.

United Nations General Assembly. "Question of East Timor: Report of the Secretary General”. A/53/951, S/1999/513, 5 May 1999.

United Nations General Assembly. "Question of Timor". Resolution 3485, 12 December 1975.

United Nations General Assembly. "Declaration on Principles of International Law Concerning Friendly Relations and Co-operation among States in Accordance with the Charter of the United Nations". Resolution 2625, 24 October 1970.

United Nations Legislation and Treaties. Law of the Territorial Sea and the Contiguous Zone of 25 February 1992". Article 2. http://www. un.org/depts/los/LEGISLATIONANDTREATIES/PDFFILES/ CHN_1992_Law.pdf.

United Nations Security Council. "Resolution 1272 (1999)," Resolution S/RES/1272, 25 October 1999. 
United Nations Security Council. "Resolution 1264 (1999)". Resolution S/RES/1264, 15 September 1999.

United Nations Security Council. "Resolution 1246 (1999)". Resolution S/RES/1246, 11 June 1999.

United Nations Security Council. "Resolutions on East Timor (1975-76)”. Resolution S/RES/389, 22 April 1976.

United Nations Security Council. "Resolutions on East Timor (1975-76)”. Resolution S/RES/384, 22 December 1975.

US Department of Defense. "Remarks by Secretary Mattis at Shangri-La Dialogue”. 03 June 2017, https://www.defense.gov/ News/Transcripts/Transcript-View/Article/1201780/remarks-bysecretary-mattis-at-shangri-la-dialogue/.

US Department of State. Remarks on “America's Indo-Pacific Economic Vision” by Michael Pompeo, Indo Pacific Business Forum, Washington DC, July 30, 2018, https://www.state.gov/secretary/ remarks/2018/07/284722.htm.

US Department of State. "Readout of Secretary Mattis' Meeting with Vietnamese Minister of National Defense Lich”. Release No. NR-285-17, 09 August 2017, https://www.defense.gov/News/ News-Releases/News-Release-View/Article/1272572/readoutof-secretary-mattis-meeting-with-vietnamese-minister-of-nationaldefens/.

US Department of State. Foreign Relations of the United States, 19771980, Volume XIII, China, edited by David P Nickles. Washington: United States Government Printing Office, 2013.

US Department of State. Foreign Relations of the United States, 1969-1976, Volume E-12, Documents on East and Southeast Asia, 1973-1976, edited by Bradley Lynn Coleman, David Goldman and David Nickles. Washington: United States Government Printing Office, 2011.

US Department of State. Foreign Relations of the United States, 19691976, Volume XVIII, China 1973-1976, edited by David P Nickles. Washington, DC: United States Government Printing Office, 2008. US Embassy and Consulate in Vietnam. "US-Vietnam Joint Vision Statement”. 07 July 2015, https://vn.usembassy.gov/u-s-vietnamjoint-vision-statement/.

US Embassy and Consulate in Vietnam. "Fact Sheet: US-Vietnam Comprehensive Partnership". 16 December 2013, https:// vn.usembassy.gov/20131216factsheet-us-vietnam-comprehensivepartnership/. 
US Embassy in the Philippines. "Signing of Enhanced Defense Cooperation Agreement”. 28 April 2014, https://ph.usembassy.gov/ signing-enhanced-defense-cooperation-agreement/.

Valencia, Mark J. China and the South China Sea Disputes. Adelphi Paper 298. Oxford: International Institute for Strategic Studies, 1995.

Van Evera, Stephen. Guide to Methods for Students of Political Science. London: Cornell University Press, 1997.

Vatikiotis, Michael RJ. Indonesian Politics under Suharto: The Rise and Fall of the New Order. 3rd ed. London: Routledge, 1998.

Viet Nam News. "Viet Nam, India hold strategic talks". 25 October 2017, http://vietnamnews.vn/politics-laws/416212/viet-nam-indiahold-strategic-talks.html\#4vmrZtxelGI35uu7.97.

Villamor, Felipe. "Philippines halts work in South China Sea, in a bid to appease Beijing”. The New York Times, 08 November 2017, https://www.nytimes.com/2017/11/08/world/asia/philippinessouth-china-sea.html.

Viviani, Nancy. "Australians and the Timor Issue". Australian Journal of International Affairs 30, no. 2, 1976: 197-226.

Wain, Barry. "The US position in the South China Sea". In Entering Unchartered Waters? ASEAN and the South China Sea, edited by Pavin Chachavalpongpun, 247-265. Singapore: Institute of Southeast Asian Studies, 2014.

Walt, Stephen. The Origins of Alliances. London: Cornell University Press, 1987.

Waltz, Kenneth. Theory of International Politics. New York: McGraw Hill, 1979.

Weatherbee, Donald E. International Relations in Southeast Asia: The Struggle for Autonomy. 2nd ed. Maryland: Rowman \& Littlefield, 2009. Weatherbee, Donald. "Southeast Asia and ASEAN: Running in Place". Southeast Asian Affairs, 2012: 3-22.

Weatherbee, Donald. "The Diplomacy of Stalemate". In Southeast Asia Divided: The ASEAN-Indochina Crisis, edited by Donald Weatherbee, 1-31. Boulder, CO: Westview Press, 1985.

Wee Sile, Aza. "China sends missiles to contested South China Sea”. CNBC News, 16 February 2016. https://www.cnbc. com/2016/02/16/china-appears-to-have-deployed-missiles-onwoody-island-in-south-china-sea-us.html.

White House Office of the Press Secretary. "Remarks by President Obama and President Quang of Vietnam in Joint Press Conference". 23 May 2016, https://obamawhitehouse.archives.gov/the-pressoffice/2016/05/23/remarks-president-obama-and-president-quangvietnam-joint-press. 
White House Office of the Press Secretary. "Joint Statement of the US-ASEAN Special Leaders' Summit: Sunnylands Declaration”. 16 February 2016, https://obamawhitehouse.archives.gov/thepress-office/2016/02/16/joint-statement-us-asean-special-leaderssummit-sunnylands-declaration.

White House Office of the Press Secretary. "Remarks by President Obama and President Benigno Aquino III of the Philippines in Joint Press Conference". 28 April 2014, https://obamawhitehouse.archives. gov/the-press-office/2014/04/28/remarks-president-obama-andpresident-benigno-aquino-iii-philippines-joi.

White House Office of the Press Secretary. "Remarks by President Obama and President Truong Tan Sang of Vietnam after Bilateral Meeting". 25 July 2013, https:/ / obamawhitehouse.archives.gov/thepress-office/2013/07/25/remarks-president-obama-and-presidenttruong-tan-sang-vietnam-after-bila.

White House Office of the Press Secretary. "Joint statement by President Barack Obama of the United States of America and President Truong Tan Sang of the Socialist Republic of Vietnam". 25 July 2013, https://obamawhitehouse.archives.gov/the-pressoffice/2013/07/25/joint-statement-president-barack-obama-unitedstates-america-and-preside.

White House Office of the Press Secretary. "Remarks by President Obama to the Australian Parliament". Parliament House Canberra, Australia, November 17, 2011, https://obamawhitehouse.archives. gov/the-press-office/2011/11/17/remarks-president-obamaaustralian-parliament.

White, Hugh. "The Road to INTERFET: Reflections on Australian Strategic Decisions Concerning East Timor, December 1998September 1999”. Security Challenges 4, no. 1, Autumn 2008: 69-87. Whiting, Allen. "ASEAN Eyes China: The Security Dimension". Asian Survey 37, no. 4, April 1997: 299-322.

Whitlam, Gough. "Australia, Indonesia and Europe's Empires". Australian Outlook 34, no. 1, 1980: 3-12.

Wikileaks Cable. "Patriotic HCMC and Hanoi Rallies Nevertheless Challenge GVN Sense of Order". The Wikileaks Public Library of US Diplomacy. 21 December 2007, 07HOCHIMINHCITY1266_a. https://wikileaks.org/plusd/cables/07HOCHIMINHCITY1266_a. html.

Wikileaks Cable. "Sino-Vietnam Territorial Dispute Entangles Multiple Multinational Energy Firms". Wikileaks Public Library of US Diplomacy, 07 September 2007, 07HANOI1599_a, https://wikileaks. org/plusd/cables/07HANOI1599_a.html. 
Wikileaks Cable. "Latest Round of China-Vietnam Border Talks Break Down". The Wikileaks Public Library of US Diplomacy. 26 January 2007, 07BEIJING598_a, https://wikileaks.org/plusd/ cables/07BEIJING598_a.html.

Wikileaks Cable. "Timor". The Wikileaks Public Library of US Diplomacy, 28 January 1976, 1976CANBER00646_b, https://wikileaks.org/ plusd/cables/1976CANBER00646_b.html.

Wikileaks Cable. "ASEAN: Singapore/Indonesian Relations". The Wikileaks Public Library of US Diplomacy, 06 January 1976, 1976SINGAP00046_b, https://search.wikileaks.org/plusd/ cables/1976SINGAP00046_b.html.

Wikileaks Cable. "Relations between Singapore and Indonesia". The Wikileaks Public Library of US Diplomacy, 29 December 1975, 1975JAKART15794_b, https://search.wikileaks.org/plusd/ cables/1975JAKART15794_b.html.

Wikileaks Cable. "Malaysian Government Backs Indonesia on Timor”. The Wikileaks Public Library of US Diplomacy, 22 December 1975, 1975KUALA07442_b, http://search.wikileaks.org/plusd/ cables/1975KUALA07442_b.html.

Wikileaks Cable. "Razak Visit". The Wikileaks Public Library of US Diplomacy, 23 October 1975, 1975CANBER07142_b, https://search. wikileaks.org/plusd/cables/1975CANBER07142_b.html.

Wikileaks Cable. "PRC's Emerging Policy in Southeast Asia". The Wikileaks Public Library of US Diplomacy, 15 October 1975, 1975HONGK12216_b, https://wikileaks.org/plusd/ cables/1975HONGK12216_b.html.

Wikileaks Cable. "Rajaratnam's Talks with FRG Foreign Minister". The Wikileaks Public Library of US Diplomacy, 10 October 1975, 1975STATE242323_b, https://wikileaks.org/plusd/ cables/1975STATE242323_b.html.

Wikileaks Cable. "Thai FonMin Chartchai's Talks with Miki and Miyazawa”. The Wikileaks Public Library of US Diplomacy, 07 October 1975, 1975TOKYO14290_b, https://wikileaks.org/plusd/ cables/1975TOKYO14290_b.html.

Wikileaks Cable. "PM says no need for Malaysian troops in Timor; Brunei People's Party denounces Singapore". The Wikileaks Public Library of US Diplomacy, 04 September 1975, 1975KUALA05302_b, https://search.wikileaks.org/plusd/cables/1975KUALA05302_b. html.

Wikileaks Cable. "Visit of Thai FonMin Chatchi". The Wikileaks Public Library of US Diplomacy, 07 August 1975, 1975WELLIN02277_b, https://wikileaks.org/plusd/cables/1975WELLIN02277_b.html. 
Wikileaks Cable. "GOM Recognises PRG". The Wikileaks Public Library of US Diplomacy, 03 May 1975, 1975KUALA02386_b, https:// wikileaks.org/plusd/cables/1975KUALA02386_b.html.

Wikileaks Cable. "Lee Kuan Yew Visits Thailand". The Wikileaks Public Library of US Diplomacy, 25 April 1975, 1975BANGKO07412_b, https://wikileaks.org/plusd/cables/1975BANGKO07412_b.html.

Wikileaks Cable. "GOI Views on Cambodia and Vietnam". The Wikileaks Public Library of US Diplomacy, 11 April 1975, 1975JAKART04295_b, https://wikileaks.org/plusd/cables/1975JAKART04295_b.html.

Wikileaks Cable. "General Brown Meeting with General Panggabean". The Wikileaks Public Library of US Diplomacy, 08 April 1975, 1975JAKART04135_b, https://wikileaks.org/plusd/ cables/1975JAKART04135_b.html.

Wikileaks Cable. "US Views on Portuguese Timor". The Wikileaks Public Library of US Diplomacy, 06 March 1975, 1975JAKART02814_b, https://www.wikileaks.org/plusd/cables/1975JAKART02814_b. html.

Wikileaks Cable. "Meeting with Thai Foreign Minister Charunphan". The Wikileaks Public Library of US Diplomacy, 08 January 1975, 1975BANGKO00355_b, https://www.wikileaks.org/plusd/ cables/1975BANGKO00355_b.html.

Wolfers, Arnold. "National Security as an Ambiguous Symbol". Political Science Quarterly 67, no. 4, 1952: 481-502.

Wong, Edward. "China Hedges Over Whether South China Sea Is a 'Core Interest' Worth War'. New York Times, 30 March 2011, http:// www.nytimes.com/2011/03/31/world/asia/31beijing.html.

Xinhua News Agency. "ASEAN wants peaceful settlement of E.Timor issue". 12 April 1999.

Xinhua News Agency. "Ramos defends Manila's action on East Timor conference”. 25 May 1994.

Xinhua News Agency. "Indonesia has sovereignty over East Timor Ramos". 11 May 1994.

Yearbook of the United Nations 1990, Volume 44. The Hague: Martinus Nijhoff, 1990.

Yearbook of the United Nations 1989, Volume 43. The Hague: Martinus Nijhoff, 1989.

Yearbook of the United Nations 1985, Volume 39. Dordrecht: Martinus Nijhoff, 1985.

Yearbook of the United Nations 1984, Volume 38. New York: Office of Public Information United Nations, 1984.

Yearbook of the United Nations 1983, Volume 37. New York: Office of Public Information United Nations, 1983. 
Yearbook of the United Nations 1982, Volume 36. New York: Office of Public Information United Nations, 1982.

Yearbook of the United Nations 1981, Volume 35. New York: Office of Public Information United Nations, 1981.

Yearbook of the United Nations 1979, Volume 33. New York: Office of Public Information United Nations, 1979.

Yearbook of the United Nations 1976, Volume 30. New York: Office of Public Information United Nations, 1976.

Yearbook of the United Nations 1975, Volume 29. New York: Office of Public Information United Nations, 1975.

Yeo, Andrew. Activists, Alliances, and Anti-US Base Protests. Cambridge: Cambridge University Press, 2011.

Yue, Chia Siow. "The Asian Financial Crisis: Singapore's Experience and Response”. ASEAN Economic Bulletin 15, no. 3, 1998: 297-308. Zakaria, Fareed. From Wealth to Power: The Unusual Origins of America's World Role. Princeton, NJ: Princeton University Press, 1998.

Zhang, Xiaoming. "China's 1979 War with Vietnam: A Reassessment". The China Quarterly, 184, December 2005: 851-874. 


\section{Index}

\section{A}

Aceh 45, 129

Acharya, Amitav 3-4, 5-6, 58, 103, 150, 194, 214, 215, 226-7

actor, ASEAN as $16-17,102,224$

AFTA (ASEAN Free Trade Area) 55

Alatas, Ali 48, 124, 125, 133, 135

alliances $2,15,71,72,77,78,102$, 219,222

Aneja, Urvashi 6

Annan, Kofi 136

APEC (Asia-Pacific Economic Cooperation) 125, 130, 135, 140, 142, 181, 188, 189

Apodeti (Timorese Popular Democratic Association) 28, 29, 31, 46, 47

Aquino III, Benigno 176, 178, 180, 181

arbitration tribunals $176-7$

ARF (ASEAN Regional Forum) xiv, 6, 172, 194, 195, 215, 227

Armacost, Michael 51

arms supplies

East Timor invasion $30,32-3$

to Indonesia $50-1,121,141$

to the Philippines 185

to Thailand 92, 95

to Vietnam 181

ASA (Association of Southeast Asia) xi, xii

ASEAN Summits $\quad 181-2,184,186$, 189

ASEAN Way xiii, xv, 58, 151

ASEAN-China Free Trade Area 170

Asia- Pacific Conference on East Timor 125

Asian financial crisis (1997) xv, 117, 118, 126-9, 130, 148-9, 153, 220, 222

Asian Strategy and Leadership Institute 189

Asia-Pacific Coalition for East Timor (APCET) 124
Australia

air bases 92

and ASEAN 152

East Timor humanitarian crisis 117, 120, 140-5, 147, 220, 222

East Timor invasion 25, 26, 30, 33, $46,57,224$

and Indonesia $38-44,52-4,57$, 118-19, 122-3, 126, 131-4, 138, $141,144,147-9,220$

seabed border agreements 31,39

South China Sea Dispute 190, 193

autonomy

constructivist theory xvii, 1, 2, 6, 103, 194, 214, 215

East Timor humanitarian crisis 117, $118,131,132-6,149-50$

and power 16

realist theory xvii, 7, 194-5, 215-18, 221

South China Sea Dispute 163

and sovereignty 19

Third Indochina War 102-3, 105

vanguard state theory $222-3$

B

Ba, Alice 4, 58, 103, 150, 193, 194, 214

Baba, Ghafar 78

Baja Jr, Lauro 168

BAKIN Badan Koordinasi Intelijens Negara (State Intelligence

Coordinating Body) 33

Balakrishnan, Vivian 190

balance of power politics $6-7,15,105$, 167, 180, 192, 222, 223

Bali Summit (1976) 55

Balibó Declaration 47-8

Bangkok Declaration (1967) xiii, xv

Barry, Robert 121, 147

Beeson, Mark 192

Bellamy, Alex J. 226-7

Belo, Carlos Felipe Ximenes 120, 124, 129

Betts, Alexander $4-5,6$ 
Bian Kie, Lim 43, 54

bilateral agreements 15, 122, 169, 180, 184,188

Blair, Dennis 140

Boren, David 121

boycotts 55, 141, 223-4

British colonialism xii

Brown, Harold 75, 88

Brunei xi, 46, 55, 60, 163, 193

Brzezinski, Zbigniew 75, 93

Cambodia

Cambodia conflict (Third Indochina War) 2, 71-116, 214-15, 216, 219, 222, 224

and China 77, 84, 98, 174, 184

communism 27, 73

critical theoretical scholarship 219

and Indonesia 98-100, 135

joining ASEAN xi, xiv, 225

South China Sea Dispute 174, 184

and Thailand 3, 82-3

and Vietnam 73-4, 84-5, 86-7

Capie, David 227

capitalist social order 105, 106

Carter, Ashton 179

Carter, Jimmy 51-2, 71, 87-8, 93, 95

case study methodology 17-20, 213

Cayetano, Alan Peter 187

Charunphan Isarangkun $\mathrm{Na}$ Ayuthaya 77

Chatchai Chunawan 77, 78, 79

China

alliances with 2

and ASEAN xiv, 2, 81-3, 90-1, 94, 170, 194, 215, 217, 220

and Cambodia 77, 84, 98, 174, 184

Cold War xii

East Timor $30,45,50$

as extra-regional power 6-7

and Indonesia 37, 81-2, 128

and the Khmer Rouge 84

and the Philippines 81, 167-8, 173, 176-92, 223

South China Sea Dispute 163-211

and the Soviet Union $75,80,81,87$, 100-1

and Thailand $71,81,82,85,91,93$, 94, 95, 99, 217

Third Indochina War 7, 71, 103-4, 216, 219, 222

and the UN 96

and the US $75,81,166,171-2,175$, 178-9, 188-9, 192, 193, 216, 224

US-Indonesian Consultative

Commission 37 and Vietnam $7,72-5,79,81,87-91$, 93, 95, 99, 101, 170-1, 178-9, 181, 186-8, 190-1, 217, 223

China-Vietnamese Border War of 1979 72

civil war $31-3,43,86$

Clinton, Bill 121, 122, 131, 140, 142, 224

Clinton, Hillary 172

coalitions of the willing 142

code of conduct 168-70, 189-90

coercive power dynamics $2,15-16$, 118, 147-8, 152, 170-1, 188, 190, 223-4

cohesion norms $\mathrm{xx}, 17,44-7,214-15$

East Timor humanitarian crisis 118 , $134-5,151$

East Timor invasion $\quad 44-7$

South China Sea Dispute 164, 178

Third Indochina War 90-1, 102-6

Cold War

and ASEAN's origins xi-xiv

Australia 38

East Timor $25-70$

Indonesia 27-31

colonial era xii

Comecon 85

common threat consensus 76, 224

Commonwealth 46

communism

Cambodia 83-4

East Timor invasion 27, 32, 34, 35, 59-60

fears over expansion of xii, 29-30, $59-60$

Indonesia 81

Vietnam 29-30, 73, 85

Communist Party of Kampuchea (CPK) 83

Communist Party of Thailand (CPT) 85

conflict avoidance 7, 104, 216

consensus-based decision making xiii, xv, 2, 7, 9, 16, 77, 103-4, 151, 164, 216

constructive realism 11

constructivist scholarship xvii, 1-6, 11, 214-15

East Timor humanitarian crisis 150

East Timor invasion 58

South China Sea Dispute 193-4

Third Indochina War 103

containment policies $2,82,85$

cooperative norms 2, 9, 13-14

Cotton, James 30

counterinsurgency 51, 52, 92

covariation 18

Crawford, Timothy 13, 15, 102, 221 
critical theoretical scholarship xvii, 8-10, 59, 105-6, 152-3, 218-20

D

Dai Bingguo 172

De Castro, Cruz 173, 183, 191-2

de Venecia, Jose 125

Declaration of the Conduct of Parties in the South China Sea (DOC) 169-70, 174, 191

Declaration of the Formation of the Coalition Government of Democratic Kampuchea (CGDK) 98

decolonization $25,28-9,35,49,59$, 218

Democratic Kampuchea 74, 82, 86, 87,96

Deng Xiaoping $71,75,81,82,85$, 87-8, 93, 94, 95, 96

Dibb, Paul 133

Dili coup, East Timor $32-3,41,123$

Dim Syamsudin 128

diplomacy

large power diplomacy 5, 95, 96-101

South China Sea Dispute 173, 176, 180, 194

Third Indochina War 79, 82, 85, 89

vanguard state theory 15,223

disinformation 32

do Amaral, Xavier 50

domino effect $34,79,93,95,128$

Downer, Alexander 132, 133, 134, 142

Drummond, Catherine 227

Dunn, James 42, 48

Dutch colonialism xii

Duterte, Rodrigo 182-4, 185-6, 187, 188, 190, 191, 192

\section{E}

East Asia Summit (EAS) 170, 188, 189

East Timor

constructivist scholarship 58,150

humanitarian crisis $117-62,215$, $217,219-20,222-3$

invasion 2, 25-70, 214, 216, 218

realist theory $59,151-2$

selection as a case study 18,19

vanguard state theory 221-2

economic aid

to Cambodia 84,184

to Indonesia $34-5,142,149,220$

as strategy by external powers 224

to Vietnam 85, 101

Elman, Colin 11

empirical evidence base 18
Enhanced Defense Cooperation

Agreement (EDCA) 179-80

European Union 125-6, 141

Evans, Gareth 122

expansionist aims

China 81, 164, 166, 171, 174, 176, 188, 189, 191

Indonesia $30-1,57,60,216,218$

Soviet Union $34,72,75,76,80,84$

Vietnam xiv, 78, 83, 84, 93, 105-6, 222

$\mathbf{F}$

FALINTIL (National Liberation Armed Forces of East Timor) 33, 48, 119, 138

Federation of Malaysia xii

Five-Power Agreement 46

food shortages $127-8$

forced resettlements 45,84

Ford, Gerald 34, 37-8, 50-1, 219

Foreign Ministers (ASEAN) 89, 97, $98,145,169,184,186,190$

Fraser, Don 51

Fraser, Malcolm 42-4, 52, 54

Freedom of Navigation (FON) operations 179

free-trade agreements $128,170,175$, 188

French colonialism xii

FRETILIN (Revolutionary Front for an Independent East Timor) 28-34, 41, 45, 47-50, 52-3, 56, 60, 119,216

Frey, Frederick 17

FUNSK (Kampuchean United Front for National Salvation) 86,87

\section{G}

Gerard, Kelly 8

Glas, Aarie 2-3

Goh Chok Tong 135, 143

Gorbachev, Mikhail 100

Grieco, Joseph 10, 11

Gruber, Lloyd 3

GRUNK (Royal Government of National Union of Kampuchea) 74 guerrilla warfare $48,52,81,93$ Gupta, Sourabh 189

$\mathrm{H}$

Haacke, Jürgen $4,58,104,150-1$, 193, 194, 214

Habib, Philip 36, 45, 51, 76

Habibie, Bacharuddin Jusuf 129, 130-1, 132, 133, 134, 135, 137, 138, 139, 141-2, 144, 145, 147

habits of peace $2-3$ 
Handel, Michael 13

Hayton, Bill 166, 186

hegemonic power 31, 72, 75, 81, 102

Heng Samrin 86, 87, 96, 97

Heydarian, Richard Javad 192

history of ASEAN xi-xx, 44

Hong Kong 130

Hong Lei 177

Hor Nam Hong 174

Howard, John 131, 133-4, 137, 139, $141,143,144$

Howard Doctrine 143, 144

Hua, Huang 75, 93, 95

human rights

Cambodia 96

conference 124

contraventions in East Timor 48, 52

East Timor $118,120,121,131$

and the future of ASEAN 225-8

Philippines 183

humanitarian crisis, East Timor $117-62$

humanitarian principles, shift towards 225-8

Hun Sen 184

identity, and the making of security communities 3-4

India 193, 195, 225

Indochinese Federation 73,87

Indonesia

and ASEAN 16, 123-6, 134-5

Asian financial crisis (1997) 118, 127-9

and Australia 38-44, 52-4, 57, 118-19, 122-3, 126, 131-4, 138, 141, 144, 147-9, 220

British colonialism xii

and Cambodia 98-100, 135

and China $37,81-2,128$

Cold War 27-31

communism 81

Dutch colonialism xii

East Timor humanitarian crisis 117-62, 222

East Timor invasion 7, 25-70, 216, 218, 221-2

expansionist aims 30-1, 57, 60, 216, 218

integration into the region xiv

and INTERFET 144-5

joining ASEAN xi

and Malaysia xiii, 44, 46, 58-9, 125

post-Cold War 119-21

readying for war 92

and Singapore xiii, 55, 135

small annexations 45 and Thailand xiii, 95, 124-5

and the US $27,31,34-8,48-54,76$,

$118,119,121,126,129-31,147-9$

as vanguard state $25-6,33-44,57$,

117-18, 148, 221-2, 223, 224

and Vietnam 76-7, 78, 90, 99

Indo-Pacific Business Forum 188

informal alliances 71, 72, 78, 219, 222

informal decision-making xiii, 2

institutionalization processes 5

institutions

ASEAN institutional cohesion 44-7, 134-5

as venues for cooperation 2

Westphalian model of sovereignty

$12,16,225,227-8$

intelligence gathering $15,32,138$

interest convergence

East Timor humanitarian crisis 118 , 121-6

East Timor invasion 26, 57, 60

as independent variable 11-15

partial interest convergence $\mathrm{xx}$, 13-14, 19, 164, 174-82, 192

South China Sea Dispute 164-5, 166-74, 191-3

Third Indochina War 71, 102

and vanguard state theory 221-3, 224

INTERFET (International Force for East Timor) 142-3, 144-5, 146-8, 150-1, 152, 220, 222

International Conference on Kampuchea 96-7

international law 49, 57, 179, 181

International Monetary Fund (IMF) $127,128,130,132,142,220$

International Relations 8, 213

International Stabilisation Forces (ISF) 146

intra-ASEAN power dynamics 16 , 76-9, 90-2, 191

J

Jakarta Informal Meetings(JIM) 99-100

Japan xii, 78, 130, 144, 175, 190, 193, 195,225

Job, Brian L. 6

Joint Communiqués 56, 57, 77, 145, 174, 184, 194, 216

Joint Marine Seismic Undertaking (JMSU) 170, 173

Joint Vision Statements 180-1

Jones, David M 6-7, 13, 58, 59, 104-5, 151-2, 194-5, 216, 217

Jones, Lee 8, 9, 10, 59-60, 105, 152-3, 218-20 
journalists 119, 120

Juddery, Bruce 41

K

Kaplan, Robert D 166, 189

Keating, Paul 122

Khieu Samphan 97, 98, 99

Khmer Rouge 27, 71, 74, 83, 84-5, 86, 93, 94, 97, 98, 99, 222

Khoo, Nicholas 2, 194

Khukrit Pramot 79

Kiernan, Ben 30, 48

Kingsbury, Damien 120

Kissinger, Henry 34, 36, 37, 45, 50-1, $75,76,77,78,80,82$

Koh, Tommy 188-9

Konfrontasi xiii, 44

Kopassus military units 122-3, 132

Kopsak Chutikul 135

KPNLF (Khmer People's National Liberation Front) 97, 99

Krasner, Stephen 12, 16, 147-8

Kriangsak Chamanan 85, 91, 93

Kuala Lumpur Declaration 80

Kuantan principle 98-9

L

Lao People's Democratic Republic 100

Laos

and China 77

communism 27, 73

joining ASEAN xi, xiv, 225

and Vietnam 73

Larson, Charles 168

Le Hai Binh 177

Le Thi Thu Hang 187

Lee Hsien Loong 182, 189

Lee Kuan Yew xi, 46, 56, 78, 79, 81, 82,143

Leekpai, Chuan 125

Leifer, Michael xiv, 6, 7, 13, 28, 58, 59, 104-5, 151, 167, 194-5, 215-16, 217, 219

liberation movements 86

Lim Bian Kie 43, 54

Lim King Siang 144

localized sovereignty 227

Lon Nol, General 73-4

\section{M}

Macau 30

Mahathir, Prime Minister 143-4, 145, 227

Malaya xii

Malaysia

Asian financial crisis (1997) 130

and Brunei 46 and China $81,92,168$

East Timor humanitarian crisis 143-4, 145

East Timor invasion $\quad 45-7,56,60$

formation of Federation xii

and Indonesia xiii, 44, 46, 58-9, 125

joining ASEAN xi

readying for war 92

South China Sea Dispute 163, 165, 169, 193

and the Soviet Union 80

and Thailand 95

Third Indochina War 89

and the US 76

and Vietnam 76, 78, 99

Malik, Adam 28, 33, 36, 47, 53, 76

Manglapus, Raul 124

Mann, Michael 16

Mansfield, Edward D. 3

Marcos, President 79

massacres 48, 84, 119-20, 136

materialist state theory 8

Mattis, Jim 185, 187

McCredie, John 30, 39

Mearsheimer, John 4, 13

Mekong hydroelectic scheme 79

Merom, Gil 10, 11

military aid

in Cambodia 84,98

East Timor invasion $34-5,36,37$, 50-1, 52

to Indonesia $121,122-3$

to the Philippines 193

to Thailand $92,94-5$

to Vietnam $71,73,84,85,101$

Vietnam War 76

see also arms supplies

military bases 39, 76, 79, 180, 186

military coups

Cambodia 73-4, 86

East Timor 32, 41

Indonesia 27

militia violence 137-9, 143

Mill, John Stuart 226

Ministerial Meetings 56-7, 77, 89, 173-4, 216

Mischief Reef 163, 166, 174

Moerdani, General 30, 43

Mondale, Walter 52, 94, 95

Morgenthau, Hans 12-13

Moro Islamic Liberation Front (MILF) 45

Moynihan, Daniel Patrick 50

multilateral initiatives $170,175,178$, 184, 188-9, 193, 194, 215

multinational companies 170-1

multinational forces 139-40, 142, 145

Murdani, General 36 
Murtopo, General Ali 32, 41, 54

Myanmar xi, xiv, 225

$\mathbf{N}$

Narine, Shaun xii

National United Front for an Independent, Neutral, Peaceful and Co-operative Cambodia 97, 99

neorealism 4, 8, 10, 11

neo-Weberian views of the state 8

New Zealand 25, 78

Newsom, US Ambassador 36, 51

Ngo Xuan Lich 187

NGOs (non-governmental organisations) 125

Ninth ASEAN Ministerial Meeting in Manila (1976) 56, 57

Nixon, Richard 38, 75

non-interference principle

critical theoretical scholarship 8, 152-3

East Timor humanitarian crisis 150, 215

East Timor invasion 58, 214

and humanitarian principles 226

realist theory 151

South China Sea Dispute 195-6

and sovereignty $\mathrm{xvi}, 2,3,16,227$

technology of power mechanisms 218

Third Indochina War 102-6

non-statist approaches xvii, 218, 220

norms, as independent variables 3-6, 58,214

North Korea 188

Norway 86, 124

Oakley, Robert 52

Obama, Barack 164, 171-2, 175, 178, 180-2, 185, 187

Oh Ei Sun 189

oil/gas reserves $31,39,46,57,120$, 165-6, 170, 186, 187

Operasi Komodo 32

Orchard, Phil 4-5

P

Pacific War xii

Panetta, Leon 175

Panggabean, General Maraden 78

Paracel Islands $163,165,171,185-6$

Paris Peace negotiations 76

partial interest convergence $\mathrm{xx}, 13-14$, 19, 164, 174-82, 192

Patani United Liberation Organization (PULO) 45

Pathet Lao 27 peacekeeping 97, 117, 118, 137, 139, $140,141-2,146-8,149$

Peacock, Andrew 42-3, 53-4

Pell, Claiborne 121

People's Liberation Army (PLA) 88, 93

Permanent Court of Arbitration (PCA) 176-7, 183-4

Pham Van Dong 79, 87

Phan Hien 79-80

Phay Siphan 184

Philippines

and China $81,167-8,173,176-92$, 223

and East Timor 45, 145, 153

independence movements 45

and Indonesia xiii, 124, 135, 153

intra-ASEAN power dynamics 16

and Japan 193

joining ASEAN xi

readying for war 92

South China Sea Dispute 163-211

and the Soviet Union 80

and the US 76, 79, 168, 173-80,

182-5, 187-8, 190-2, 195, 218, 223

as vanguard state $164,181,191-3$, 223, 224

and Vietnam 77, 79, 90, 181

Pol Pot 74, 83-4, 85, 86, 91, 96

Pompeo, Mike 188

Portugal 28, 32, 33, 47, 49, 86, 123, 136

power

and autonomy 16

balance of power politics $6-7,15$, 105, 167, 180, 192, 222, 223

coercive power dynamics $2,15-16$, 118, 147-8, 152, 170-1, 188, 190, 223-4

countervailing power 95

hegemonic power $31,72,75,81$, 102

and institutions 3

intra-ASEAN power dynamics 16 , 76-9, 90-2, 191

mutually reinforced by cooperation 3

relative power 15

and sovereignty 16

technology of power mechanisms 8, 218

power-maximizing behaviour 15, 57

Prasong Soonsiri 125

Prem Tinsulanond 94, 99

Press, Daryl 13, 15, 102, 221

Priess, David 3

process-tracing methodology 18

propaganda $32,47,56$

protests $128,129,171$ 
Q

Quang, President 181

R

Ramos, Fidel 124

Ramos-Horta, José $31,49,120,124$, 125

Razak, Tun 46, 47

realist theory xvii, xviii, 3, 6-7, 9, 10-11, 12, 15, 213, 215-18

East Timor humanitarian crisis 151-2

East Timor invasion 59

South China Sea Dispute 194-5

Third Indochina War 102, 104-6

refugees $79,91,92,96$

regional autonomy, norm of xvii, 2 , 6, 19, 103, 105, 149, 150, 194, 195, 215

'regional solutions for regional problems' 6, 100, 150, 194-5, 216

relative power 15

responsibility to protect (R2P) $\mathrm{xx}$, 225-8

retrenchment policies xiii, $26,58,75$, 76, 81, 83, 219

Reyes, Angelo 168

Rithauddeen, Tengku Ahmad 89-90

Rüland, Jürgen 16

Russia 182, 185

see also Soviet Union

\section{S}

Sabah xii

Santa Cruz massacre $120,123,129$, 141

Sarawak xii

Sary, Ieng 82, 86, 91

Scarborough Shoal 173, 174, 176, 177, 179, 183

Schlesinger, James 81

Schweller, Randall 3

seabed border agreements 31,39

SEANET (Southeast Asian Human

Rights Network) 124-5

SEANWFZ (Southeast Asian Nuclear

Weapon Free Zone) 169

secessionism 45

secondary interests 13

security concerns

about China 85

after invasion of Cambodia 92

Australian 38

critical theoretical scholarship 219

in East Timor 29

as reason for establishment of ASEAN xiii, $x v$
Third Indochina War 106, 214-15

Vietnam 85

security-maximizing behaviour 15

See Seng Tan 226

self-defence 50,88

self-determination $26,35,40,41,49$,

53, 122, 132, 134, 144, 149

self-help principle 15

Severino Jr, Rodolfo 134, 227

Sheridan, Greg 123

Shesterinina, Anastasia 6

Sihanouk, Prince 74, 83, 97, 98, 99-100

silent partner approaches $35-7$

Singapore

and Cambodia 96, 100

and China 81, 91, 168

and East Timor 46, 54-6, 143, 145, 153

and the Federation of Malaysia xii, xiii

and Indonesia xiii, 55, 135

joining ASEAN xi

South China Sea Dispute 178

and the Soviet Union 81

and the US 76, 175, 188-9

and Vietnam 76

Sino-Vietnamese border war 88

Smith, Michael LR 6-7, 13, 58, 59, 104-5, 151-2, 216, 217

Smyser, WR 35-6

social conflict theory 8,105

social forces xvii, 1, 8-10, 11, 195, 218

social order $8,59,105,106,218$

socialization effects 2, 4

Son Sann 97, 98, 99

South China Sea Dispute 163-211

constructivist scholarship 193-4, 215

critical theoretical scholarship 220

realist theory $194-5,217-18$

selection as a case study 18,19

vanguard state theory 223

South Korea 130

Southeast Asia Command (SEAC) xii

Southeast Asian Treaty Organization

(SEATO) xii

sovereignty

in ASEAN Treaty xvi

and power 16

as technology of power 9

as vital interest 13

Westphalian model of $12,16,225$, 227-8

Soviet Pacific Fleet 92

Soviet Union

and Cambodia 74-81, 87

and China $75,80,81,87,100-1$ 
Cold War xii

collective security ideas 80

East Timor 30, 45

expansionist aims 34,72

and Malaysia 80

and the Philippines 80

and Singapore 81

Third Indochina War 71, 103-4, 105-6

and the US 80

US-Indonesian Consultative

Commission 37

and Vietnam $71,73,74-5,85,90$, 99, 100-1, 219

special relationships 73

Spratly Islands 165, 167-8, 171, 177, 186, 194

Stahl, Max 120

state, role in the international system 9

state interest 13

state of emergency 119

states

critical theoretical scholarship 8

power 16

state-centric realist paradigm 12

as unified, rational actors 12

vanguard state theory xviii-xix,

10-16, 213, 218, 221-8

Stinchcombe, Arthur 18

Storey, Ian 190, 193

strategic shields 38

student-led demonstrations 128,129 , 171

Suharto, General xiii, 27, 28, 29, 32,

$34,35,36,37-8,41,43,44,47,52$,

$55,58,59,60,99,100,117,119$,

$121,127,128,130,131,151,152$, 218, 219, 220, 222

Sukarno, General xiii, 27, 44, 60

Sukarnoputri, Megawati 138

Supreme National Council 101

Suratman, Tono 138

Surin Pitsuwan 135

survival, as basic state interest 13,15 , 221

$\mathrm{T}$

Taiwan 163, 165, 167

Tan, See Seng 226

Tan Boon Seng 55

Tang Siew Mun 178

technology of power mechanisms 8 , 218

territorialization 10

Thailand

Asian financial crisis (1997) 126-7

and Cambodia 3, 82-3 and China $71,81,82,85,91,93$,

94, 95, 99, 217

colonial era xii

and East Timor 145

independence movements 45

and Indonesia xiii, 95, 124-5

joining ASEAN xi

and Malaysia 95

neutrality 91

and the Soviet Union 80

Third Indochina War 7, 71, 89, 219, 222

and the US $71,95,175$

as vanguard state $72,89-95,101-2$, 104, 217, 222, 223

and Vietnam 71, 77-8, 79, 91, 93, 94, 95, 98-9

Vietnam War 76

Thayer, Carlyle 174

Third Indochina War 71-116, 214-15

constructivist scholarship 103

critical theoretical scholarship 219

realist theory $7,102,104-6,216$

selection as a case study 18,19

vanguard state theory 222,224

threat perceptions 15

Timor Gap 31, 39, 57, 120, 147

Timor-Leste 146

Tjan, Harry 43

TPP (Trans-Pacific Partnership) 175, 188

Treaties of Friendship 73, 85, 87

Treaty of Amity and Cooperation (TAC, 1976) xvi

Trump, Donald 185, 186, 187-9, 191, 192

Truong Tan Seng 180

Truong Trieu Duong 181

U

UDT (Timorese Democratic Union) $28,29,31,32-3,47$

UK (United Kingdom) xii, 25, 86, 141

UN (United Nations)

Cambodia 97-8

Charter xiii, xvi

Credentials Committee 96

diplomacy 89, 96

East Timor 47, 49-50, 117, 136-7

General Assembly 89-90, 98, 136, 226

General Assembly Resolution 35/6 96, 97

General Assembly Resolution 3485

$25,49,52-3,54-5$

International Conferences 94, 96 
peacekeeping 97, 117, 118, 142, 146-8, 149

Secretary General 91, 136, 139, 141, 142, 145

Security Council 3, 49, 51, 86-7, 89, 101, 136, 142

Security Council Resolution 384 49, 56

Security Council Resolution 1264 142

Special Representatives 50

Third Indochina War 72

UNAMET (United Nations Mission in East Timor) 137, 138-9, 142, 143

UNCLOS (Convention on the Law of the Sea) 165, 176

UNMISET (UN Mission of Support in East Timor) 146

UNTAET (United Nations

Transitional Administration in East Timor) 146

United Malays National Organisation (UMNO) 125

US (United States)

and ASEAN 152, 174-82, 190, 224

Asian financial crisis (1997) 126

and Cambodia 74, 86, 87-8, 93-4

and China $75,81,166,171-2,175$, 178-9, 188-9, 192, 193, 216, 224

Cold War xii

East Timor humanitarian crisis 117, 137, 139-42, 147, 220, 222

East Timor invasion $25,26,50-1$, $57,58,59,216,219$

free and open Indo-Pacific strategy 188-9

and Indonesia 27, 31, 34-8, 48-54, 76, 118, 119, 121, 126, 129-31, 147-9

and Malaysia 76

and the Philippines $76,79,168$, 173-80, 182-5, 187-8, 190-2, 195, 218, 223

pivot to Asia $164,165,175-6$

realist theory $6-7$

and Singapore $76,175,188-9$

South China Sea Dispute 163-4, 166, 167, 168, 174-91, 192, 195, 215

and the Soviet Union 80

and Thailand 71, 95, 175

Third Indochina War 71

and Vietnam 45, 74-5, 174, 175-6, 178, 180-1, 192, 195, 218, 223

US Interagency Intelligence Memorandum 84
US-Indonesian Consultative

Commission 37

\section{V}

Van Evera, Stephen 18

Vance, Cyrus 52, 75

vanguard state theory xviii-xix, 10-16, 213, 218, 221-8

variables, continuous 13

variables, dependent and independent 11-12

Vietnam

and Cambodia $73-4,84-5,86-7$

and China $7,72-5,79,81,87-91$, 93, 95, 99, 101, 170-1, 178-9, 181, 186-8, 190-1, 217, 223

Cold War xii

communism 27, 45, 73

diplomatic relations with ASEAN

states 79

French colonialism xii and India 193

and Indonesia 76-7, 78, 90, 99

intra-ASEAN power dynamics 16

joining ASEAN xi, xiv, 225

and Malaysia 76, 78, 99

and Philippines 77, 79, 90, 181

and Singapore 76

South China Sea Dispute 163-211 and the Soviet Union 71, 73, 74-5, 85, 90, 99, 100-1, 219

Third Indochina War 71-116, 219 and the US $45,74-5,174,175-6$, 178, 180-1, 192, 195, 218, 223 as vanguard state $164,181,191-3$, 223, 224

Vietnam War 74, 75-7, 85

vital interests 13, 15, 31, 102, 221

voice opportunities thesis 10,11

\section{W}

Walt, Stephen 102

Waltz, Kenneth 4, 13

watershed treaty 123, 141

Weatherbee, Donald xv

West New Guinea 31

West Papua 45, 129

West Timor 28, 33, 40

Westphalian model of sovereignty 12 , $16,225,227-8$

White, Hugh 132, 141, 142-3

Whitehouse, Charles 82

Whitlam, Gough 29, 39-42, 46, 53

Willesee, Don 39

Winspeare Guicciardi, Vittorio 50, 53

Wiranto, General 128, 135, 140, 142

Wolff, Lester 51-2 
Woolcott, Richard 38, 41, 122, 123, 133

World Bank 127, 140, 142

World Trade Organisation 130

$\mathrm{X}$

Xi Jinping 163, 187, 189

Xiu Dong Jia 171

Y

Yang Jiechi 172

Yasay Jr, Perfecto 183

Yeo, George 172

Yothin Mattayomnan 125

Z

ZOPFAN (Zone of Peace, Freedom and Neutrality) $80,83,90,92,99$, 169 
"An original argument, based on vanguard state theory... A very original and superb piece of scholarship."

Andrew Tan, Macquarie University

Laura Southgate is a Lecturer in Politics and International Relations at Aston University.
Examining how the Association of Southeast Asian Nations (ASEAN) has responded to external threats over the past 50 years, this book provides a compelling account of regional state actions and foreign policy in the face of potential sovereignty violation.

The author draws on a large amount of previously unanalysed material, including declassified government documents and WikiLeaks cables, to examine four key cases since 1975. Taking into account state interests and the role of external powers, the author develops the 'vanguard state theory' to explain ASEAN state responses to sovereignty violation, which, it is argued, has universal applicability and explanatory power. 